NIPER/BDM-0027

Distribution Category UC-122

\title{
GEOLOGICAL AND PRODUCTION CHARACTERISTICS OF STRANDPLAIN/BARRIER ISLAND RESERVOIRS IN THE UNITED STATES
}

\author{
By \\ E. Lance Cole \\ Mike Fowler \\ Susan Jackson \\ Michael P. Madden \\ Thomas K. Reeves \\ S. Phillip Salamy \\ Mark A. Young
}

December 1994

Work Performed Under Contract No. DE-AC22-94PC91008

\author{
Prepared for \\ U.S. Department of Energy \\ Assistant Secretary for Fossi Energy \\ - Edith Allison, Project Manager \\ Bartlesvilte Project Office \\ P.O. Box 1398 \\ Bartlesville, OK 74005
}

\author{
Prepared by \\ BDM-Okdahoma, Inc. \\ P.O. Box 2565 \\ Bartlesville, OK 74005
}




\section{DISCLAIMER}

This report was prepared as an account of work sponsored by an agency of the United States Government. Neither the United States Government nor any agency thereof, nor any of their employees, make any warranty, express or implied, or assumes any legal liability or responsibility for the accuracy, completeness, or usefulness of any information, apparatus, product, or process disclosed, or represents that its use would not infringe privately owned rights. Reference herein to any specific commercial product, process, or service by trade name, trademark, manufacturer, or otherwise does not necessarily constitute or imply its endorsement, recommendation, or favoring by the United States Government or any agency thereof. The views and opinions of authors expressed herein do not necessarily state or reflect those of the United States Government or any agency thereof. 


\section{DISCLAIMER}

Portions of this document may be illegible in electronic image products. Images are produced from the best available original document. 


\section{TABLE OF CONTENTS}

1 BACKGROUND AND OBJECTIVES

2 DESCRIPTION OF THE RESOURCE …........................................... 2-1

2.1 Overview of the Class 4 Oil Resource................................................................. 2-1

2.1.1 Distribution of the Class 4 Resource .................................................................. 2-1

2.1.2 Heavy Versus Light Oil in Class 4 Reservoirs ................................................... 2-3

2.1.3 Production and Operator Profile for Class 4 ................................................... 2-3

2.2 General Geologic Characteristics of Class 4 Reservoirs ............................................ 2-7

2.2.1 Strandplain/Barrier Island Deposition ............................................................ 2-7

2.2.1.1 Depositional System Classifications ................................................ 2-8

2.2.1.2 Depositional Processes .............................................................. 2-10

2.2.1.3 Facies Description......................................................................... 2-11

2.2.2 Geologic Controls on Reservoir Architecture and Properties ........................ 2-16

2.2.2.1 Key Geologic Factors and Their Independent Effects ................... 2-16

2.2.2.2 Interaction of Geologic Factors ...................................................... 2-19

2.2.2.3 External and Internal Dimensions of

Strandplain/ Barrier Island Features .............................................. 2-21

2.2.2.4 Importance of Sequence Stratigraphic Considerations ................... 2-22

2.2.3 Summary of Known Interwell-Scale Depositional Heterogeneities

Affecting Fluid Flow ....................................................................................... 2-22

2.3 Overview of Major Class 4 Plays ...................................................................... 2-23

2.3.1 Reservoir Characteristics of Class 4 Plays ................................................... 2-24

2.3.2 Production and Improved Recovery in Class 4 Plays ..................................... 2-25

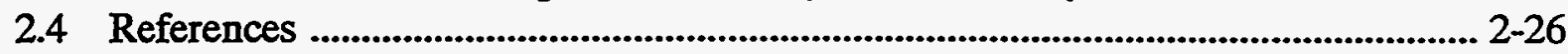

\section{MAJOR TEXAS}

STRANDPLAIN/BARRIER ISLAND PLAYS........................................... 3-1

3.1 Overview of Texas Plays ........................................................................... 3-1

3.2 Frio Strandplain/Barrier Island Play ........................................................................ 3-6

3.2.1 Play Description ............................................................................................. 3-6

3.2.2 Reservoir Characteristics, Models, and Major Controls on Production ......... 3-8

3.2.3 Production Characteristics.............................................................................. 3-10

3.2.4 Improved Oil Recovery Projects ..................................................................... 3-10

3.3 Jackson Strandplain/Barrier Island Play ...................................................................... 3-13

3.3.1 Play Description ......................................................................................... 3-13

3.3.2 Reservoir Characteristics, Models, and Major Controls on Production ......... 3-15

3.3.3 Production Characteristics.............................................................................. 3-16

3.3.4 Improved Oil Recovery Projects ............................................................... 3-16

3.4 Cretaceous, Salt-Related Play ...................................................................................... 3-18 


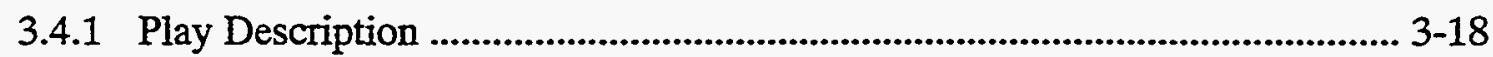

3.4.2 Reservoir Characteristics, Models, and Major Controls on Production........ 3-18

3.4.3 Production Characteristics............................................................................. 3-19

3.4.4 Improved Oil Recovery Projects .......................................................... 3-20

3.4.4.1 Polymer Flooding ...................................................................... 3-20

3.4.4.2 Alkaline-Polymer Projects ............................................................ 3-20

3.4.4.3 In Situ Combustion ..................................................................... 3-21

3.4.4.4 Steam Projects................................................................................ 3-21

3.4.4.5 $\quad \mathrm{CO}_{2}$ Miscible Project ............................................................... 3-23

3.5 IOR Activity in Other Plays ......................................................................... 3-23

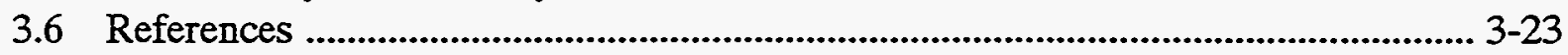

4 MAJOR OKLAHOMA

STRANDPLAIN/BARRIER ISLAND PLAYS ....................................... 4-1

4.1 Overview of Oklahoma Plays .......................................................................... 4-1

4.2 Southem Oklahoma Desmoinesian Play .................................................................. 4-5

4.2.1 Basin Development History ............................................................................ 4-5

4.2.2 Reservoir and Play Characteristics .................................................................. 4-7

4.2.3 Production Characteristics............................................................................ 4-8

4.2.4 Improved Oil Recovery Projects ...................................................................... 4-8

4.2.4.1 Polymer Projects ............................................................................... 4-8

4.2.4.2 Reservoir Management ................................................................. 4-11

4.2.4.3 Thermal Projects .............................................................................. 4-11

4.3 Southern Oklahoma Bromide Play ............................................................................ 4-11

4.3.1 Basin Development History ............................................................................ 4-11

4.3.2 Reservoir and Play Characteristics ........................................................... 4-12

4.3.3 Production Characteristics.................................................................... 4-12

4.3.4 Improved Oil Recovery Projects ..................................................................... 4-13

4.4 Arkoma Morrowan Play ............................................................................................ 4-13

4.4.1 Basin Development History and Play Characteristics................................... 4-13

4.4.2 Reservoir and Production Characteristics ................................................. 4-15

4.4.3 Improved Oil Recovery Projects ................................................................. 4-15

4.5 IOR Activity in Other Oklahoma Class 4 Plays ....................................................... 4-15

4.5.1 Southern Oklahoma Missourian Play .......................................................... 4-15

4.5.2 Southeast Anadarko Morrowan Play ............................................................ 4-15

4.6 References .................................................................................................................. 4-16

\section{MAJOR CALIFORNIA}

STRANDPLAIN/BARRIER ISLAND PLAYS ........................................ 5-1

5.1 Overview of California Plays and Basin Development History ................................ 5-1

5.2 San Ardo - King City Play, Salinas Basin, California ............................................... 5-5

5.2.1. Play Description ......................................................................................... 5-5

5.2.2 Reservoir Characteristics, Models, and Major Controls on Production........ 5-8 
5.2.3 Production Characteristics......................................................................... 5-8

5.2.4 Improved Oil Recovery Projects .................................................................... 5-9

5.3 Vaqueros Formation Play, Cuyama Basin, California ............................................. 5-11

5.3.1 Play Description ........................................................................................ 5-11

5.3.2 Reservoir Characteristics, Models, and Major Controls on Production........ 5-12

5.3.3 Production Characteristics.......................................................................... 5-13

5.3.4 Improved Oil Recovery Projects ................................................................... 5-13

5.4 Vedder And Pyramid Hills Play, San Joaquin Valley, California ............................. 5-14

5.4.1 Play Description ....................................................................................... 5-14

5.4.2 Reservoir Characteristics, Models, and Major Controls on Production ........ 5-14

5.4.3 Production Characteristics.......................................................................... 5-16

5.4.4 Improved Oil Recovery Projects ................................................................ 5-16

5.5 References .................................................................................................................. 5-17

\section{MAJOR ROCKY MOUNTAIN}

STRANDPLAIN/BARRIER ISLAND PLAYS ......................................... 6-1

6.1 Overview of Rocky Mountain Plays ............................................................... 6-1

6.2 Muddy, Dakota, and Equivalent Formations Strandplain/Barrier Island Plays ........ 6-5

6.2.1 Play Description ....................................................................................... 6-5

6.2.2 Reservoir Models, Reservoir and Production Characteristics .......................... 6-8

6.2.3 Improved Oil Recovery Projects (Major Plays) ............................................. 6-12

6.2.3.1 Muddy and Frontier Plays............................................................ 6-12

6.2.3.2 Gallup Barrier Island Play ........................................................... 6-14

6.2.3.3 DJ (Dakota) Plays ...................................................................... 6-14

6.2.4 Process Technologies of Regional Interest................................................. 6-15

6.2.4.1 Cyclic $\mathrm{CO}_{2}$ Stimulation................................................................ 6-15

6.2.4.2 Gel Polymer Applications ............................................................... 6-17

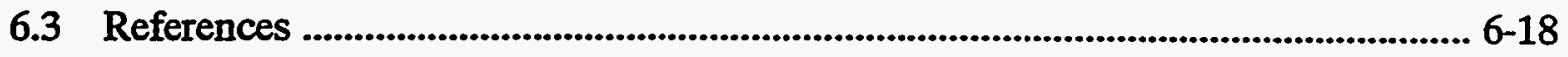

7 IMPROVED OIL RECOVERY CHALLENGES ................................... 7-1

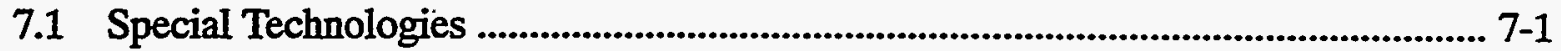

7.1.1 Reservoir Management ........................................................................ 7-1

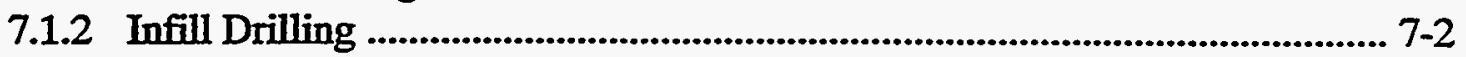

7.1.3 Computer Technologies .......................................................................... 7-2

7.1.4 Horizontal Drilling ......................................................................................... 7-3

7.2 Advanced Waterflooding ......................................................................................... 7-3

7.2.1 Polymer Flooding ....................................................................................... 7-3

7.2.2 Profile Modification (Gel Polymers) .............................................................. 7-4

7.2.3 Microbial Waterflooding .............................................................................. 7-4

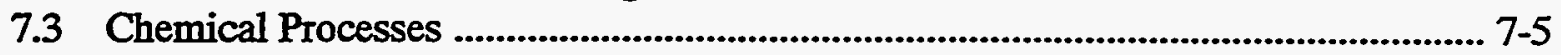

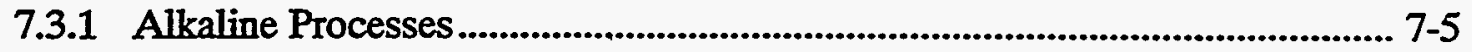

7.3.2 Micellar-Polymer (Surfactant) ................................................................. 7-5

$7.4 \mathrm{CO}_{2}$ Processes ........................................................................................... 7-6

7.5 Thermal Processes ….......................................................................................... 7-7 
7.5.1 Steam Applications ........................................................................................... 7-7

7.5.2 In Situ Combustion ................................................................................. 7-7

7.6 Regional Challenges .............................................................................................. 7-8

7.7 References …........................................................................................................ 7-8

8 FUTURE IMPROVED RECOVERY POTENTIAL FOR TORIS CLASS 4 RESERVOIRS .......................................................... 8-1

8.1 Improved Oil Recovery Potential Prediction Methodology …..................................... 8-1

8.2 Improved Recovery Potential for Class 4 …................................................................... 8-3

8.3 Abandonment Risk of the Class 4 Resource ............................................................... 8-4

8.4 Discussion of Recovery Potential for Class 4 by Region ........................................... 8-8

8.5 Reference ................................................................................................................. 8-9

9 ENVIRONMENTAL ISSUES RELATED

TO PRODUCTION OPERATIONS ............................................................. 9-1

9.1 National Environmental Policy Act .............................................................................. 9-1

9.2 Other Federal Regulations .......................................................................................... 9-4

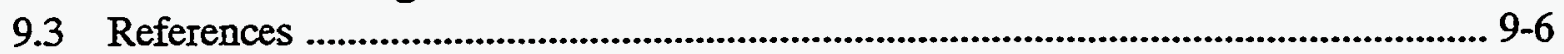

\section{APPENDICES}

A GLOSSARY OF GEOLOGICAL TERMS ................................................. A-1 B LISTING OF CLASS 4 TORIS RESERVOIRS ........................................... B-1 


\section{LIST OF FIGURES}

1.1 Classification of Clastic Reservoirs.................................................................. 1-2

1.2 Classification of Carbonate Reservoirs ................................................................ 1-2

1.3 Original Oil-in-Place for 22 Geologic Groupings ........................................................ 1-3

1.4 Remaining Oil-in-Place for 22 Geologic Groupings ................................................ 1-3

1.5 Distribution of Remaining Oil-in-Place (ROIP) for TORIS Reservoirs .................. 1-4

1.6 Total Recovery Potential for Class 4 Reservoirs ...................................................... 1-4

2.1 Distribution of Original Oil-In-Place Volumes in Class 4 Reservoirs........................ 2-2

2.2 Distribution of Class 4 TORIS Reservoirs and Remaining Oil-In-Place .................. 2-2

2.3 Light and Heavy Oil Production for Class 4 Reservoirs ............................................ 2-4

2.4 Operator Profile for Class 4 Reservoirs.......................................................................... 2-5

2.5 Generalized Geometry of Strandplain/Barrier Island Depositional Environments ......................................................................................................... 2-9

2.6 Generalized Geometry of Tidal Inlet and Associated Deposits in Barrier Island Complexes ....................................................................................................... 2-11

2.7 Strandplain/Barrier Island Facies Terminology and Generalized Vertical Sequence for a Prograding Shoreline ....................................................................... 2-12

2.8 Relative Sandbody Geometry for Various Facies in Strandplain/Barrier Island Complexes ............................................................................................................... 2-15

2.9 Distribution of Depositional Environments Associated with Barrier Islands and Tidal Inlets in Wave-Dominated and Tide-Dominated Shorelines ...................... 2-18

2.10 Examples of Microtidal Barrier Island Depositional Architecture ............................. 2-20

2.11 Remaining Oil-In-Place Distribution for Class 4 Plays in Major Regions................. 2-24

2.12 Historical Production for Class 4 Plays in Major Regions ......................................... 2-26

3.1 Stratigraphic Column for Texas Class 4 Plays ........................................................ 3-2

3.2 Historical Production for Major Texas Class 4 Plays .................................................... 3-4

3.3 Operator Profile for Texas Class 4 Reservoirs ......................................................... 3-5

3.4 Location Map for Frio, Buna, Jackson, Paluxy, and Woodbine Class 4 Plays in Texas ............................................................................................... 3-6

3.5 Paleoenvironments Associated with Deposition of Texas Class 4 Reservoirs in the Frio Play ......................................................................................................... 3-7

3.6 Structural Features Affecting Deposition of Texas Class 4 Reservoirs in the Frio Play ........................................................................................................... 3-7

3.7 Pay Continuity Functions for Major Facies of the West Ranch Field 41-A Reservoir, a Class 4 Reservoir in the Texas Frio Play ............................................... 3-12

3.8 Structural Features Affecting Deposition of Texas Class 4 Reservoirs in the Jackson Play ................................................................................................................ 3-13

3.9 Paleoenvironments Associated with Deposition of Texas Class 4 Reservoirs in the Jackson Play ........................................................................... 3-14

3.10 Viscosity-Temperature Relationship for Oil from the Texas Slocum Reservoir, a Class 4 Reservoir from the Cretaceous Salt-Related Play .................... 3-22

4.1 Structural Features of the Oklahoma Class 4 Production Areas.................................. 4-2 
4.2 Operator Profile for Oklahoma Class 4 Reservoirs .................................................. 4-4

4.3 Historical Production for Major Oklahoma Class 4 Reservoirs ................................ 4-4

4.4 Stratigraphic Column for the Pennsylvanian of South-Central Oklahoma ............... 4-7

4.5 Waterflood Efficiencies in Selected Intervals of the Sho-Vel-Tum Field,

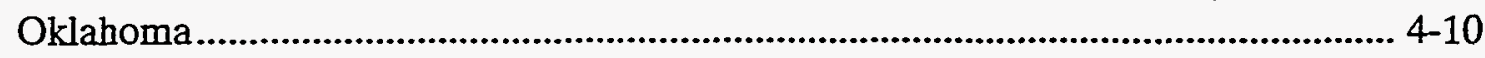

4.6 Location of Deese Interval Polymer Projects in the Sho-Vel-Tum Field,

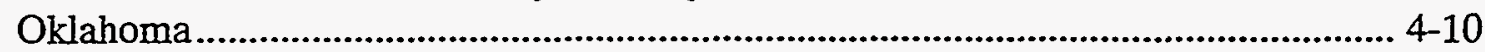

4.7 Stratigraphic Correlation Chart for Upper Mississippian and Lower Pennsylvanian Formations and Members in the Arkoma Basin ............................... 4-14

5.1 Operator Profile for California Class 4 Reservoirs .................................................... 5-4

5.2 Historical Production for Major California Class 4 Plays .......................................... 5-4

5.3 Major Basins in West Central California .................................................................... 5-5

5.4 Stratigraphic Column for the California Class 4 San Ardo-King City Play .............. 5-6

5.5 Structural Features Associated with California Class 4 Reservoirs of the San Ardo-King City Play ................................................................................................ 5-7

5.6 Stratigraphic Cross Section Through the California Class 4 San Ardo

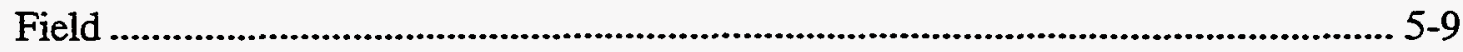

5.7 Stratigraphic Column for the California Class 4 Vaqueros Formation

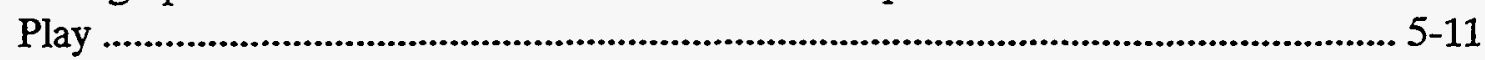

5.8 Regional Structural Map of Cuyama Basin and Vicinity .......................................... 5-13

5.9 Stratigraphic Column for the California Class 4 Vedder Formation Play ................. 5-15

6.1 Operator Profile for Rocky Mountain Class 4 Reservoirs ........................................... 6-4

6.2 Historical Production for Major Rocky Mountain Class 4 Plays ............................... 6-4

6.3 Stratigraphic Correlation Chart of Cretaceous Rocks in the Rocky Mountain Region .................................................................................................................. 6-6

6.4 Stratigraphic Model for Sequence of Deposition of the Muddy Sandstone............. 6-7

6.5 Depositional Classification of Selected Muddy Sandstone Fields. ............................ 6-9

6.6 Cumulative Production from Different Muddy Sandstone Depositional Environments .................................................................................................... 6-11

8.1 Advanced Secondary Recovery Potential for Class 4 Reservoirs .............................. 8-5

8.2 Enhanced Oil Recovery Potential for Class 4 Reservoirs .......................................... 8-6

8.3 Total Potential at Risk of Abandonment, Implemented Technology .......................... 8-7

8.4 Total Potential at Risk of Abandonment, Advanced Technology ................................ 8-7 


\section{LIST OF TABLES}

2.1 Distribution of Class 4 Oil-In-Place Volumes by State ............................................... 2-3

2.2 Oil-In-Place Volumes for Heavy and Light Oil in Class 4 ....................................... 2-4

2.3 Summary of Operators of Class 4 TORIS Reservoirs Based on 1991

Production ..................................................................................................................... 2-6

2.4 Dimensional Summary of Selected Facies in Recent and Ancient Mesotidal Barrier Island Systems

2.5 Summary of Oil-In-Place Volumes for Class 4 Plays in Major Regions ................... 2-23

2.6 Summary of Average Reservoir Parameters for Major Class 4 Plays in Each Region. $2-25$

3.1 Distribution of Texas Class 4 Oil Resource by Play ................................................... 3-3

3.2 ROIP and Average Reservoir Parameters for Major Texas Class 4 Plays ................ 3-4

3.3 Historical IOR Activity in Texas Class 4 Plays ........................................................ 3-5

3.4 Reservoir Characteristics of Texaco-Operated Class 4 Miscible $\mathrm{CO}_{2}$ Injection Projects in the Texas Frio Play ................................................................................ 3-11

3.5 Incremental Recovery Potential from Infill Drilling in Frio Strandplain/Barrier Island Play, Price in Terms of 1986 Dollars

3.6 Historical IOR Projects in the Jackson Strandplain/Barrier Island Play ................... 3-17

3.7 Active EOR Projects in the Texas Class 4 Salt-Related Play ................................... 3-20

4.1 Distribution of Oklahoma Class 4 Oil Resource by Play ........................................... 4-2

4.2 ROIP and Average Reservoir Parameters for Major Oklahoma Class 4

Plays.............................................................................................................................. 4-3

4.3 Historical IOR Activity in Oklahoma Class 4 Plays ................................................... 4-5

4.4 Historical IOR Projects in the Southern Oklahoma Desmoinesian (Pennsylvanian) Play .................................................................................................. 4-9

5.1 Distribution of California Class 4 Oil Resource by Play ........................................... 5-2

5.2 ROIP and Average Reservoir Parameters for Major California Class 4 Plays......................................................................................................................... 5-3

5.3 Production from Steam Projects in California Class 4 Plays .................................... 5-3

5.4 Average Reservoir Properties for the Aurignac and Lombardi Sands of the Class 4 San Ardo Field in California ..................................................................... 5-10

5.5 Production from Steam Projects in the California Class 4 San Ardo Field ............... 5-10

6.1 Distribution of Rocky Mountain Class 4 Oil Resource by Play ................................ 6-2

6.2 ROIP and Average Reservoir Parameters for Major Rocky Mountain Class 4

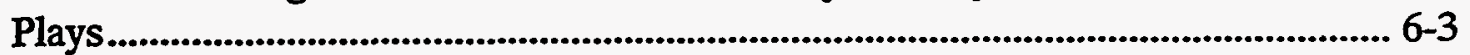

6.3 Historical IOR Activity in Rocky Mountain Class 4 Plays ....................................... 6-3

6.4 Cumulative Production and Reservoir Properties for Representative Muddy

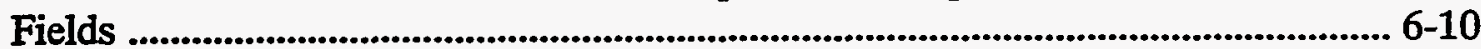

6.5 Wyoming Muddy Play Polymer Projects .................................................................... 6-12

8.1 Screening Criteria for Improved Recovery Processes, Implemented Technology Case ............................................................................................................ 8-2

8.2 Screening Criteria for Improved Recovery Processes, Advanced Technology Case 
8.3 Recovery Potential for TORIS Class 4 Reservoirs ..................................................... 8-4

8.4 Class 4 Advanced Secondary Recovery Process Potential ........................................ 8-5

8.5 Class 4 Enhanced Oil Recovery Process Potential ....................................................... 8-6

8.6 Class 4 Recovery Process Potential by Region, Implemented Technology .............. 8-8

8.7 Class 4 Recovery Process Potential by Region, Advanced Technology ................... 8-8

9.1 Types and Possible Sources of Environmental Data .................................................. 9-2

9.2 Environmental Concerns Related to Recovery Processes .......................................... 9-3 


\section{EXECUTIVE SUMMARY}

The Department of Energy's (DOE's) primary mission in the oil research program is to maximize the economically and environmentally sound recovery of oil from domestic reservoirs and to preserve access to this resource. The Oil Recovery Field Demonstration Program supports DOE's mission through cost-shared demonstrations of Improved Oil Recovery (IOR) processes and reservoir characterization methods. In the past 3 years, the DOE has issued Program Opportunity Notices (PONs) seeking cost-shared proposals for the three highest priority, geologically defined reservoir classes. The classes have been prioritized based on resource size and risk of abandonment. This document defines the geologic, reservoir, and production characteristics of the fourth reservoir class, strandplain/barrier islands.

The 330 Class 4 reservoirs in the DOE Tertiary Oil Recovery Information System (TORIS) database contain about 30.8 billion barrels of oil or about $9 \%$ of the total original oil-in-place (OOIP) in all United States reservoirs. Cumulative production from these Class 4 reservoirs is about 10.9 billion barrels. Proved reserves with current operations are estimated at 800 million barrels. Ultimate recovery with current operations is estimated at 38\% of the OOIP, leaving 19 billion barrels as the target for future IOR projects.

Plays in Texas, Oklahoma, California, and the Rocky Mountain region contain 90\% (17 billion barrels) of the Class 4 remaining oil-in-place (ROIP). Class 4 plays in Texas and Oklahoma each contain about one-third of the total Class 4 ROIP. Current (1991 data) production from Class 4 reservoirs is about 145,000 barrels of oil per day (BOPD), less than one-fourth the volumes produced in 1970. About $85 \%$ of current production is light oil with gravity greater than $20^{\circ}$ API. Small independent oil companies account for $40 \%$ of Class 4 production.

The shoreline-associated strandplain/barrier island deposits defined as Class 4 are primarily wave-constructed shallow water deposits. These deposits often form excellent reservoirs with high porosity and permeability, and under proper conditions of sediment supply and tectonic movement, strandplain/barrier island deposits may become thick and areally extensive. Some important internal heterogeneities affecting fluid flow in strandplain/barrier island reservoirs may be attributed to depositional processes, while other heterogeneities of equal or greater importance may be related to later erosional incision by fluvial channels and deposition of fine-grained sediments in those channels.

Knowledge of the geological factors and processes that control formation and preservation of reservoir deposits, external and internal reservoir heterogeneities, reservoir characterization methodology, and IOR process application can be used to increase production of the ROIP in Class 4 reservoirs. Knowledge of heterogeneities that inhibit or block fluid flow is particularly critical.

Special technologies such as multidisciplinary reservoir management, targeted infill drilling, and computerized data management have been applied with success in Class 4 reservoirs. Advanced waterflooding techniques such as polymer flooding and profile modification by gel polymers have been applied. Chemical processes such as alkaline flooding or use of micellar-polymer surfactants have been tested. Miscible $\mathrm{CO}_{2}$ and cyclic $\mathrm{CO}_{2}$ injection have also been tested, as have 
steam projects and in situ combustion. Expanded application of these technologies could recover a significant portion of the ROIP target.

Using the TORIS database of 330 of the largest strandplain/barrier island reservoirs and its predictive and economic models, the recovery potential which could result from future application of IOR technologies to Class 4 reservoirs was estimated to be between 1.0 and 4.3 billion barrels, depending on oil price and the level of technology advancement. The analysis indicated that this potential could be realized through (1) infill drilling alone and in combination with polymer flooding and profile modification, (2) chemical flooding (surfactant), and (3) thermal processes. Most of this future potential is in Texas, Oklahoma, California, and the Rocky Mountain region. Approximately two-thirds of the potentially recoverable resource is at risk of abandonment by the year 2000 , which emphasizes the urgent need for the development and demonstration of cost-effective recovery technologies.

The environmental issues that face IOR projects in pursuit of Class 4 ROIP are not different from those of other reservoir types. Environmental issues are tied to the location of the project and its relationship with existing oil production infrastructure, surface and ground waters, urban areas, ecologically sensitive areas, and the presence of historical, archaeological or paleontological sites. Demonstration projects must be in compliance with the National Environmental Policy Act (NEPA) in addition to compliance with all applicable federal, state, and local regulations and permitting requirements.

\section{ACKNOWLEDGMENTS}

This report was prepared for the U.S. Department of Energy (DOE) Bartlesville Project Office by BDM Oklahoma, Inc. under the Management and Operating Contract for DOE's National Oil and Related Programs (Contract Number DE-AC22-94PC91008). The primary authors for this document are E. Lance Cole, Mike Fowler, Susan R. Jackson, Michael P. Madden, Thomas K. Reeves, S. Phillip Salamy, and Mark A. Young. The authors wish to acknowledge Edith C. Allison of DOE's Bartlesville Project Office for her technical review of this document during its preparation. The authors also wish to acknowledge Edna Hatcher for unswerving secretarial support, Hugh Guinn for the compilation of TORIS data, Djaun Grissom for graphics support, Viola RawnSchatzinger for literature support, and Bill Linville (Consultant) for editorial support. Finally, the authors acknowledge BDM's publications department for their assistance in developing a professional work product. 


\section{CHAPTER 1 \\ BACKGROUND AND OBJECTIVES}

The Department of Energy's (DOE's) Oil Recovery Field Demonstration Program was initiated in 1992 to support DOE's primary mission in the national oil research program of maximizing the economically and environmentally sound recovery of crude oil from known domestic reservoirs and preserving access to this resource. The goals and objectives of this program support the broader strategic goals of the Federal Government's Comprehensive National Energy Policy Act of 1992 and Domestic Natural Gas and Oil Initiative of 1993. The ongoing field demonstration program supports this mission through the demonstration of improved oil recovery processes and reservoir characterization methods. The cost-shared field demonstration projects are being initiated in geologically defined reservoir classes which have been prioritized relative to the risk of abandonment and potential for incremental recovery. To date, DOE has issued Program Opportunity Notices (PONs) seeking cost-shared proposals for field demonstration projects in the three highest priority geologic classes of reservoirs. The purpose of this document is to define the geological, reservoir, and production characteristics of the fourth class, strandplain/barrier island reservoirs. Improved oil recovery activity, technological challenges, and environmental issues are also reviewed. This report provides persons interested in Class 4 reservoirs with information about the strandplain/ barrier island depositional class, and provides geologic, production, and improved recovery process analog data.

The reservoir classes are based on depositional environment and were originally defined by the Geoscience Institute for Oil and Gas Recovery Research (1990) in conjunction with the Interstate Oil and Gas Compact Commission. These geologic classifications were applied to the reservoirs that are included in the DOE Tertiary Oil Recovery Information System (TORIS). TORIS contains information on more than 2,500 domestic oil reservoirs representing two-thirds of the known domestic oil resource, or about 360 billion barrels of original oil-in-place. The TORIS reservoirs were classified into 22 geologically defined classes. The 16 clastic reservoir classes are shown in Figure 1.1, and the 6 carbonate reservoir classes are shown in Figure 1.2. These classes were then ranked in terms of original oil-in-place, remaining oil-in-place, future recovery potential, and abandonment risk to define the highest priority classes for research emphasis. Some of the 22 geologically defined classes were combined for the purposes of cost-shared field demonstration projects.

The significance of the first four DOE-defined geologic classes of reservoirs is illustrated in Figures 1.3 and 1.4. These figures compare the original and remaining oil-in-place values for the 22 reservoir classes. Class 1 was defined as fluvial-dominated deltaic reservoirs, and DOE awarded funds for 14 cost-shared field demonstration projects in April 1992. Class 2 was defined as shallow shelf (open and restricted) carbonate reservoirs, and DOE awarded funds for 11 cost-shared projects in April 1993. Class 3 was defined as slope-basin and basin clastic reservoirs, and DOE should select projects in 1994. The first three classes target about half of the remaining oil-in-place for reservoirs listed in TORIS, as shown in Figure 1.5. Class 4 targets an additional $8 \%$ of the remaining oil-in-place, or 19.8 billion barrels. The remaining $41 \%$, or 100 billion barrels of oil, will be the target for future solicitations. 


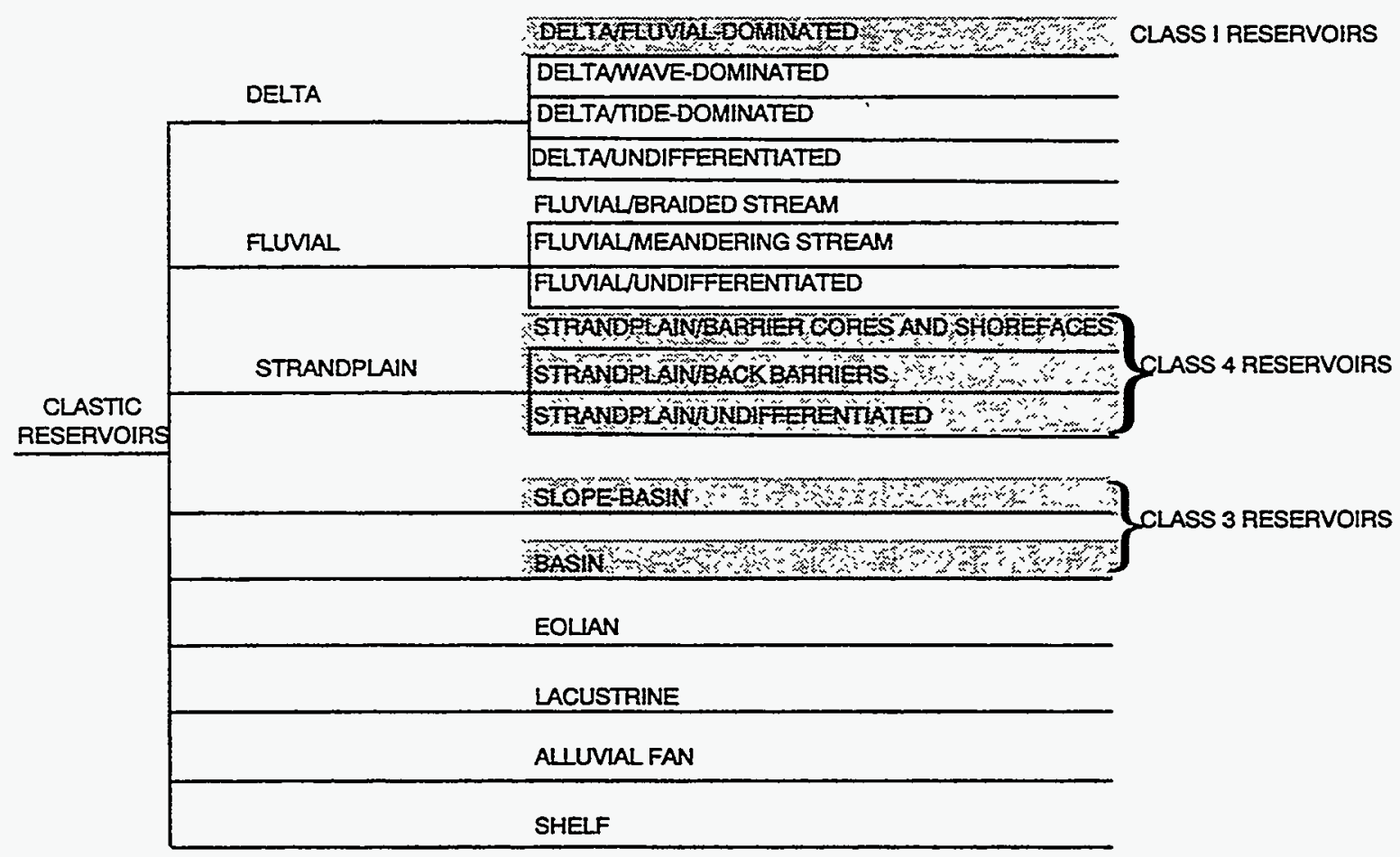

Figure 1.1 Classification of Clastic Reservoirs

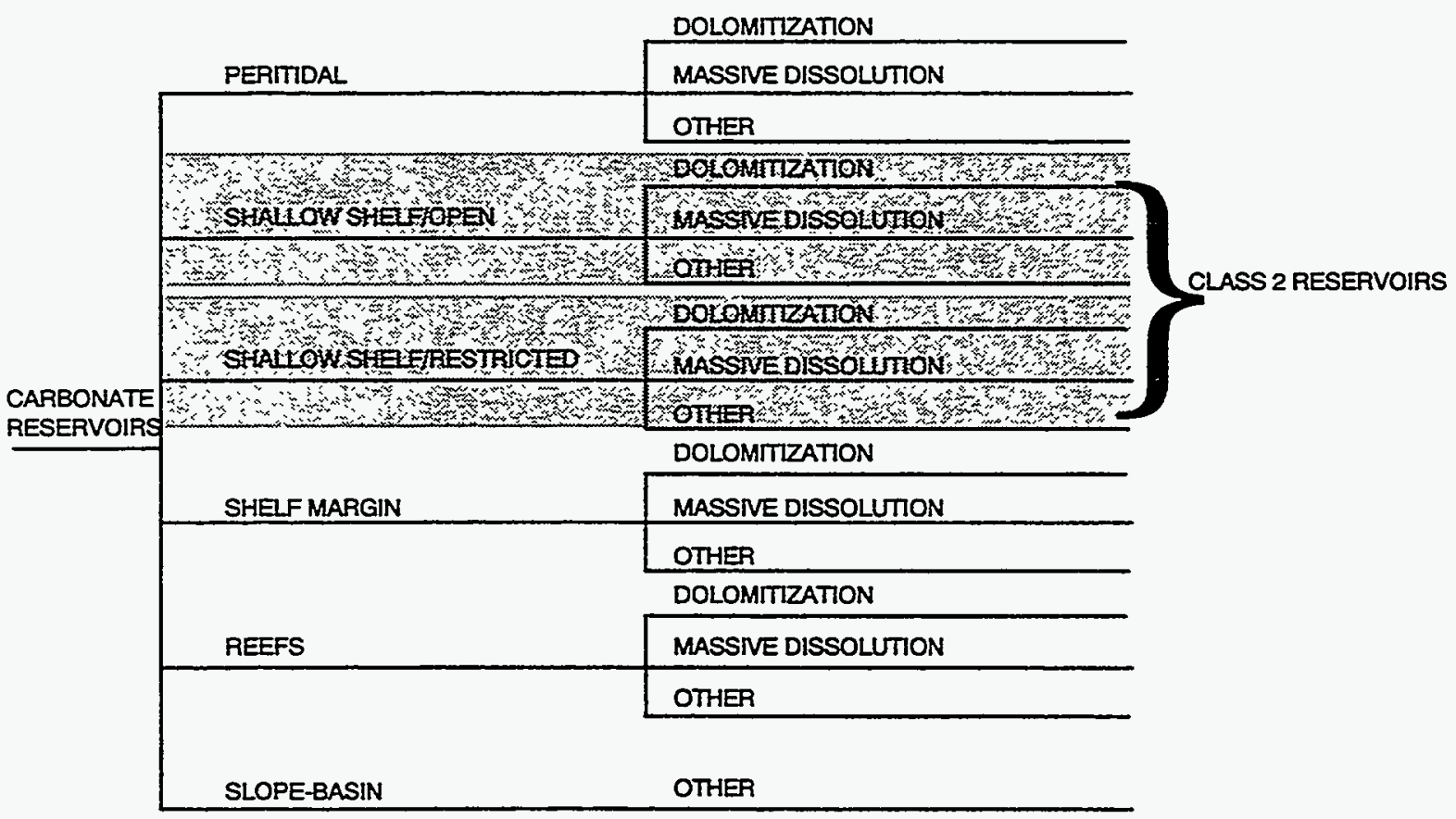

Figure 1.2 Classification of Carbonate Reservoirs 


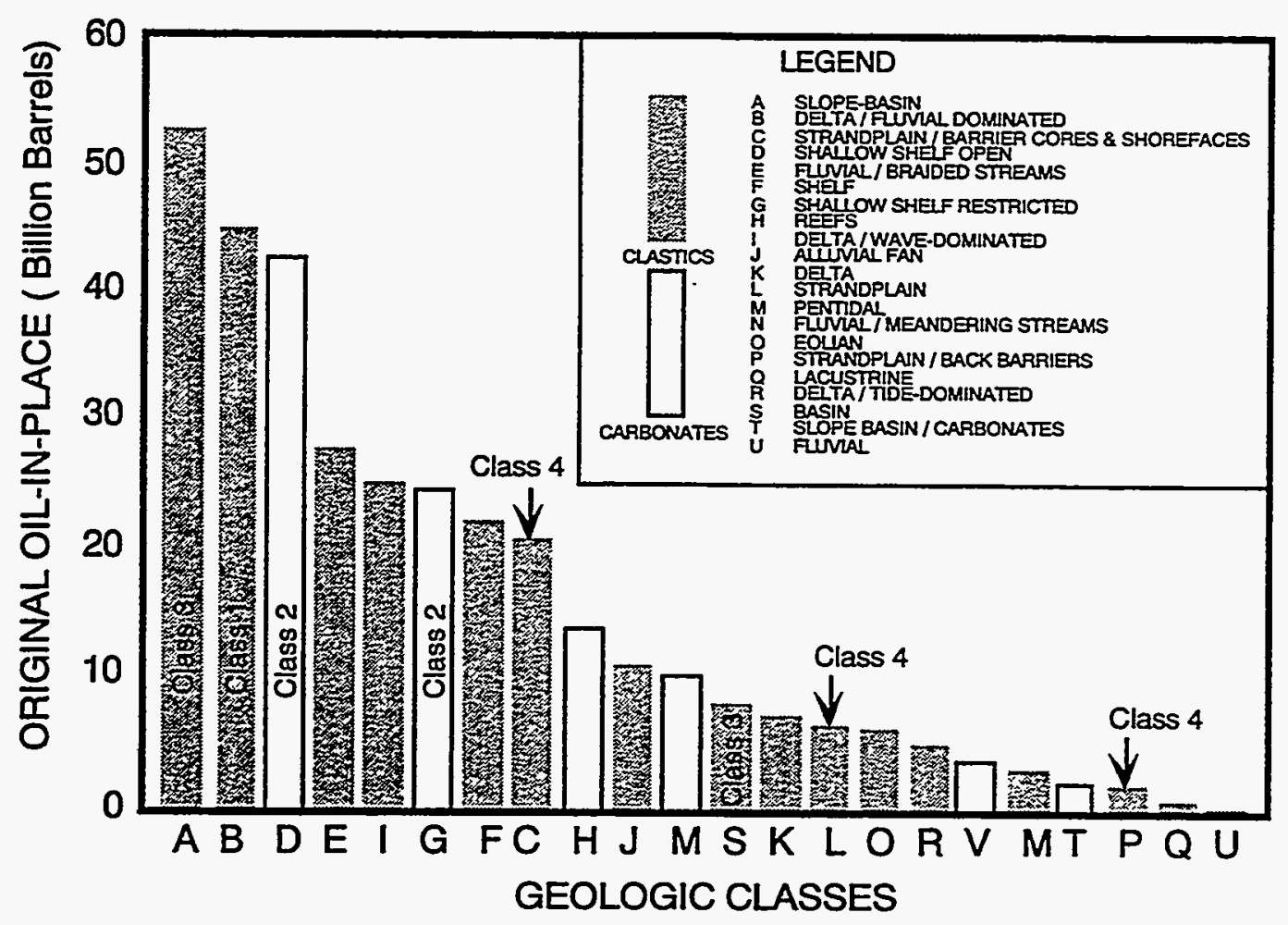

Figure 1.3 Original Oil-in-Place for 22 Geologic Groupings (Source: BPO TORIS, 1994)

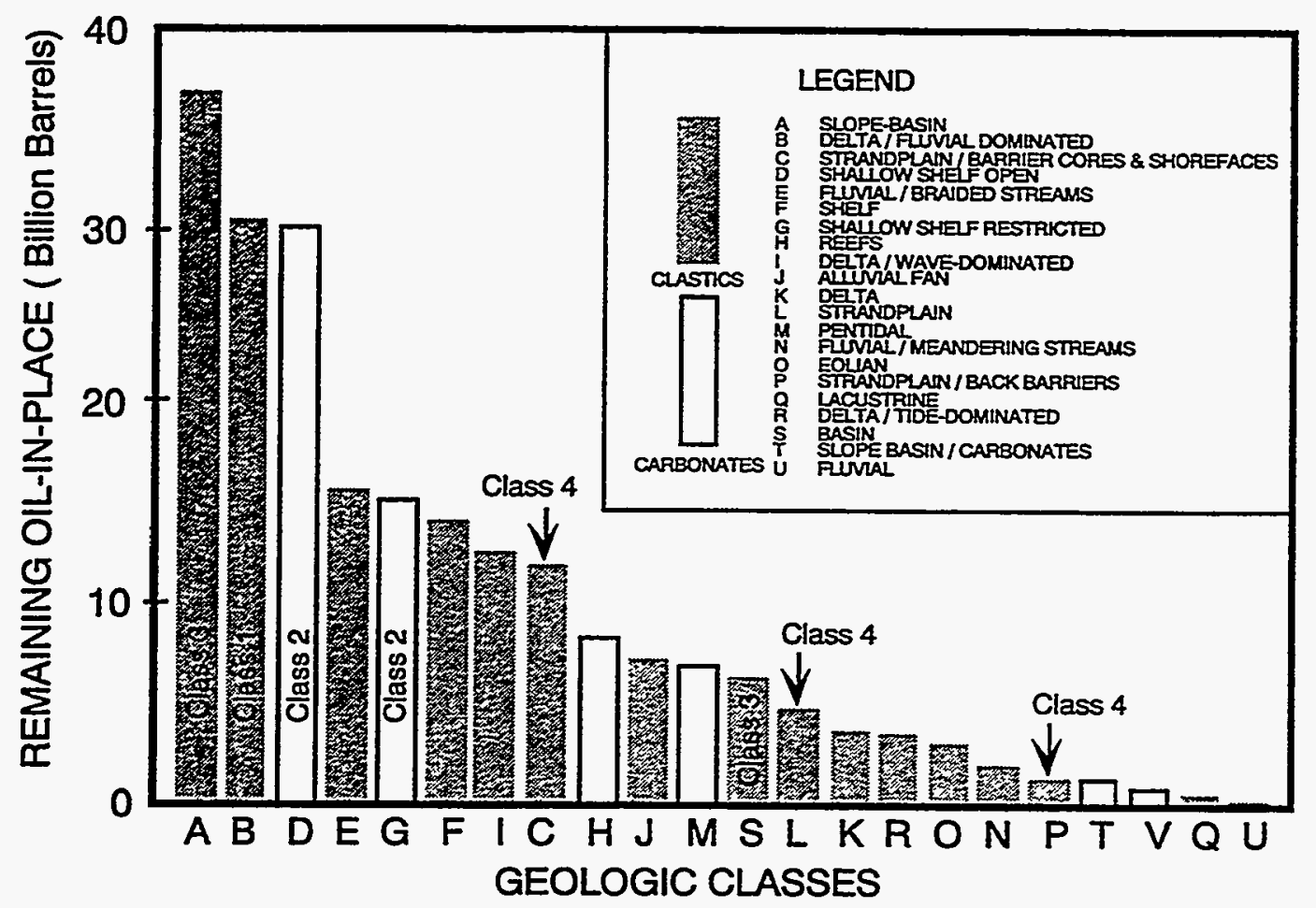

Figure 1.4 Remaining Oil-in-Place for 22 Geologic Groupings (Source: BPO TORIS, 1994) 
CLASS 1

30.8 BILLION BBL

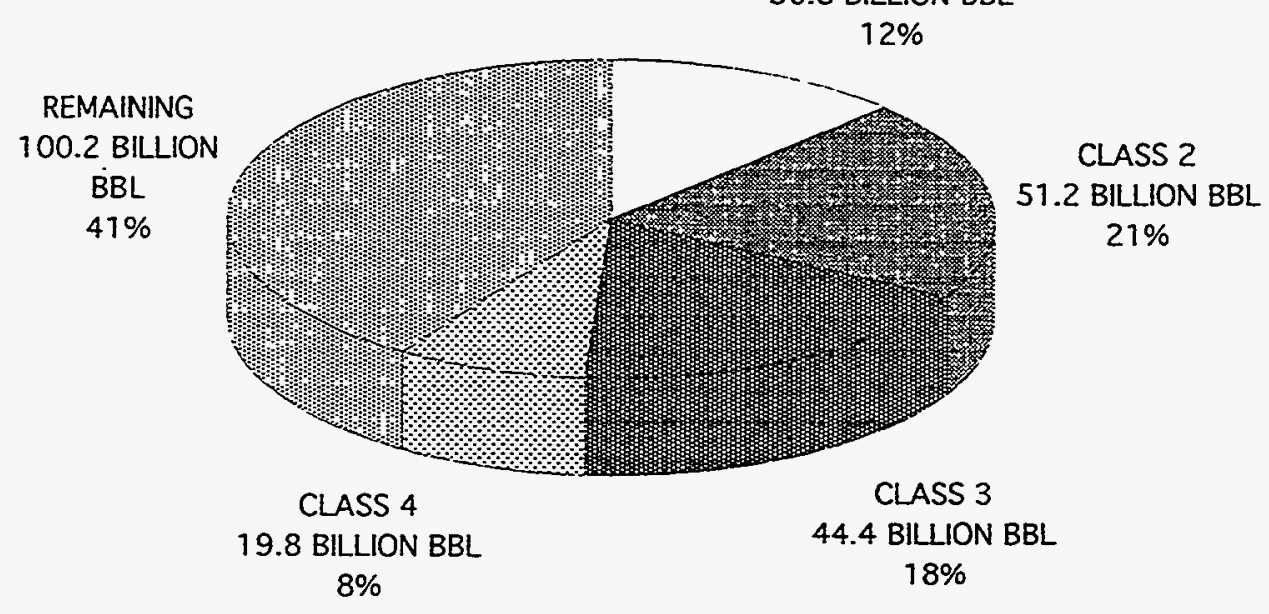

TOTAL ROIP FOR ALL CLASSES = 246 BILUON BARRELS

Figure 1.5 Distribution of Remaining Oil-in-Place (ROIP) for TORIS Reservoirs (Source: BPO TORIS, 1994)

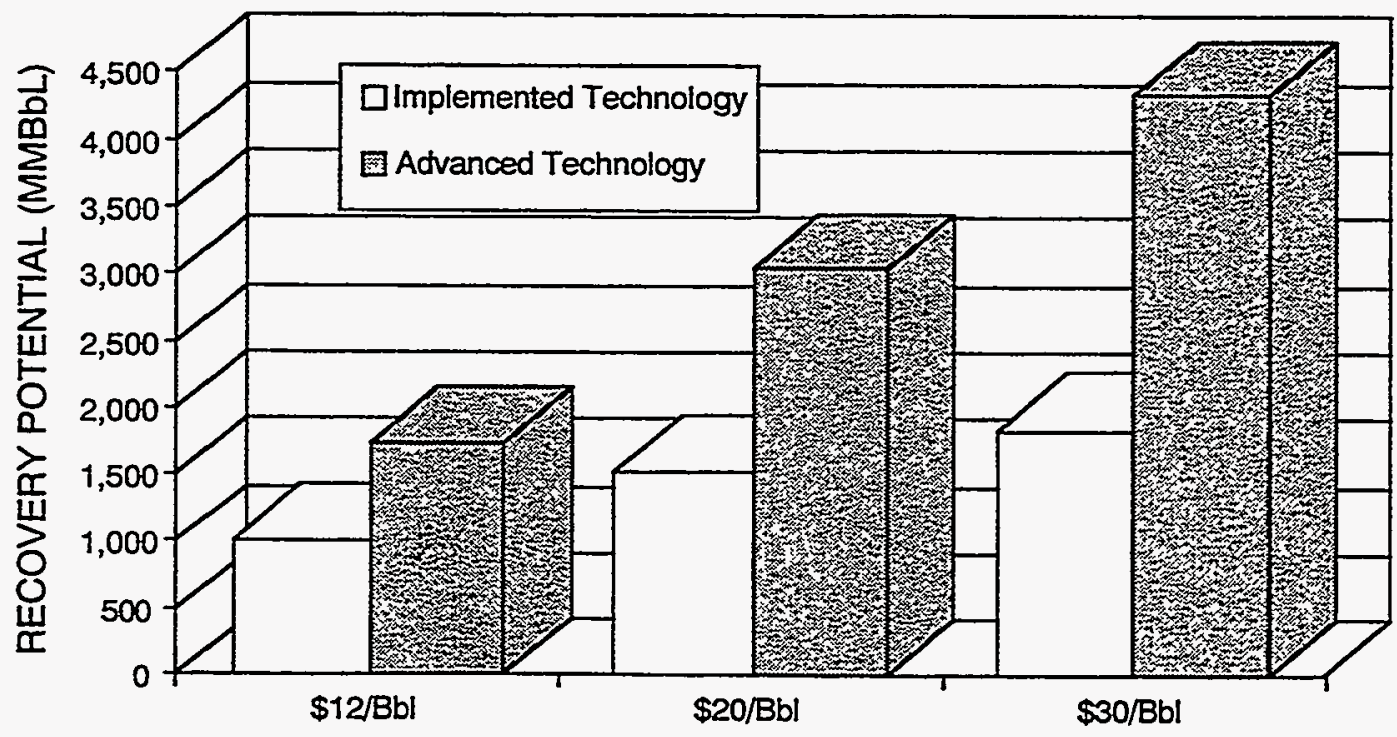

Figure 1.6 Total Recovery Potential for Class 4 Reservoirs (Source: BPO TORIS, 1994) 
Future improved recovery potential in these Class 4 reservoirs was analyzed using TORIS's predictive models. This potential ranges from 1 to 4.3 billion barrels depending on oil price and the level of technology (Figure 1.6). Approximately two-thirds of this potential is at risk of abandonment by the year 2000 emphasizing the urgent need for the application of recovery technologies in Class 4 reservoirs.

Chapter 2 presents an overview of the Class 4 resource, describes the general geologic characteristics of these reservoirs, and defines the significance of the major plays in the country. Chapters 3 through 6 examine the major strandplain/barrier island plays in regions having the highest remaining oil-in-place volumes: Texas, Oklahoma, Califormia, and the Rocky Mountains. These chapters include discussions of the geologic, reservoir, and production characteristics of the major plays in each region, and include an overview of the processes which have been implemented to improve oil recovery. Chapter 7 presents a discussion of the challenges associated with the historical and future application of improved recovery technologies in Class 4 reservoirs. Abandonment risk and TORIS future potential estimates are discussed in detail in Chapter 8. Chapter 9 discusses the environmental issues which impact oil production operations in general and the specific issues which impact the conduct of cost-shared field demonstration projects with DOE.

\subsection{References}

Geoscience Institute for Oil and Gas Recovery Research, 1990, Reservoir heterogeneity classification system for characterization and analysis of oil resource base in known reservoirs: prepared for U.S. Department of Energy, Office of Fossil Energy, Bartlesville Project Office.

United States Federal Government, 1993, The domestic natural gas and oil initiative (DNGOI): Washington, D.C., December.

United States Federal Government, 1992, Conference report on H.R. 776, comprehensive national energy policy act (EPACT): Washington, D.C. 


\section{CHAPTER 2 \\ DESCRIPTION OF THE RESOURCE}

The Department of Energy has defined Class 4 for the cost-shared oil recovery field demonstration program as strandplain/barrier island reservoirs. This depositionally defined class of reservoirs represents a significant portion of the Nation's oil resource, as described in the DOE Tertiary Oil Recovery Information System (TORIS). The purpose of Chapter 2 is to present an overview of the reservoir, production, and geological characteristics of Class 4 reservoirs. Section 2.1 describes the overall strandplain/barrier island resource in the country based on an analysis of 330 Class 4 reservoirs listed in the TORIS database. Section 2.2 describes the general geological characteristics of strandplain/barrier island reservoirs based on a comprehensive review of the relevant geological literature. Section 2.3 presents an overview of the major Class 4 plays in the United States and includes summaries of the resource, reservoir, and production characteristics, as well as a summary of the recovery processes that have been used in these plays. The major plays are described in detail in Chapters 3 through 6.

\subsection{Overview of the Class 4 Oil Resource}

The TORIS database contains information on 330 Class 4 reservoirs in the United States. The total original oil-in-place for these reservoirs is 30.8 billion barrels, which represents about $9 \%$ of the nearly 360 billion barrels of original oil-in-place in reservoirs listed in TORIS. As of 1991, the cumulative production from these reservoirs totaled approximately 10.9 billion barrels, or about $35 \%$ of the original oil-in-place (See Figure 2.1). Using the TORIS decline curve models, the projected remaining reserves at the termination of current production operations were 800 million barrels. Based on this estimation, the ultimate recovery with current operations from TORIS Class 4 reservoirs will be 11.6 billion barrels or $38 \%$ of the original oil-in-place. The projected remaining oil-in-place at the end of current operations totals 19.1 billion barrels of oil, with an estimated 6.7 billion barrels of mobile oil and 12.3 billion barrels of immobile oil. The remaining mobile oil-inplace is the target for the future application of advanced secondary recovery (ASR) technologies and the remaining immobile oil-in-place is the target for the application of enhanced oil recovery (EOR) technologies. Significant volumes of oil will be left behind unless economic improved recovery technologies can be implemented.

\subsubsection{Distribution of the Class $\mathbf{4}$ Resource}

The distribution of the TORIS-defined Class 4 reservoirs in the United States is shown in Figure 2.2, and the original oil-in-place data for each state are summarized in Table 2.1. Over half of the Class 4 reservoirs listed in the TORIS database are located in Texas (167), and these reservoirs account for almost one-third of the remaining oil-in-place for Class 4 reservoirs, or 6.0 billion barrels. Oklahoma also accounts for a significant portion of the Class 4 reservoirs, with 51 reservoirs and remaining oil-in-place of 5.9 billion barrels. The remainder of the TORIS Class 4 reservoirs are located primarily in California, the Rocky Mountains, other Mid-Continent states, and the Illinois Basin. 


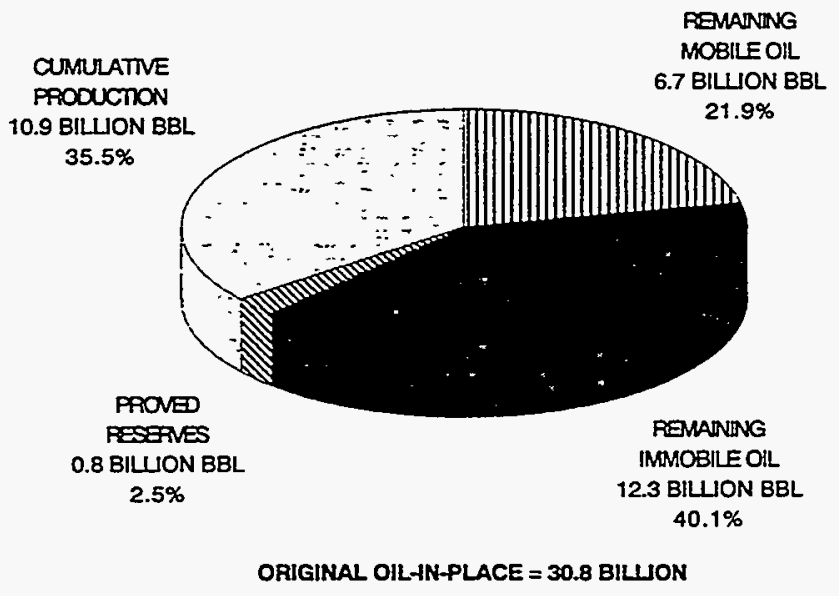

Figure 2.1 Distribution of Original Oil-In-Place Volumes in Class 4 Reservoirs (Source: BPO TORIS, 1994)

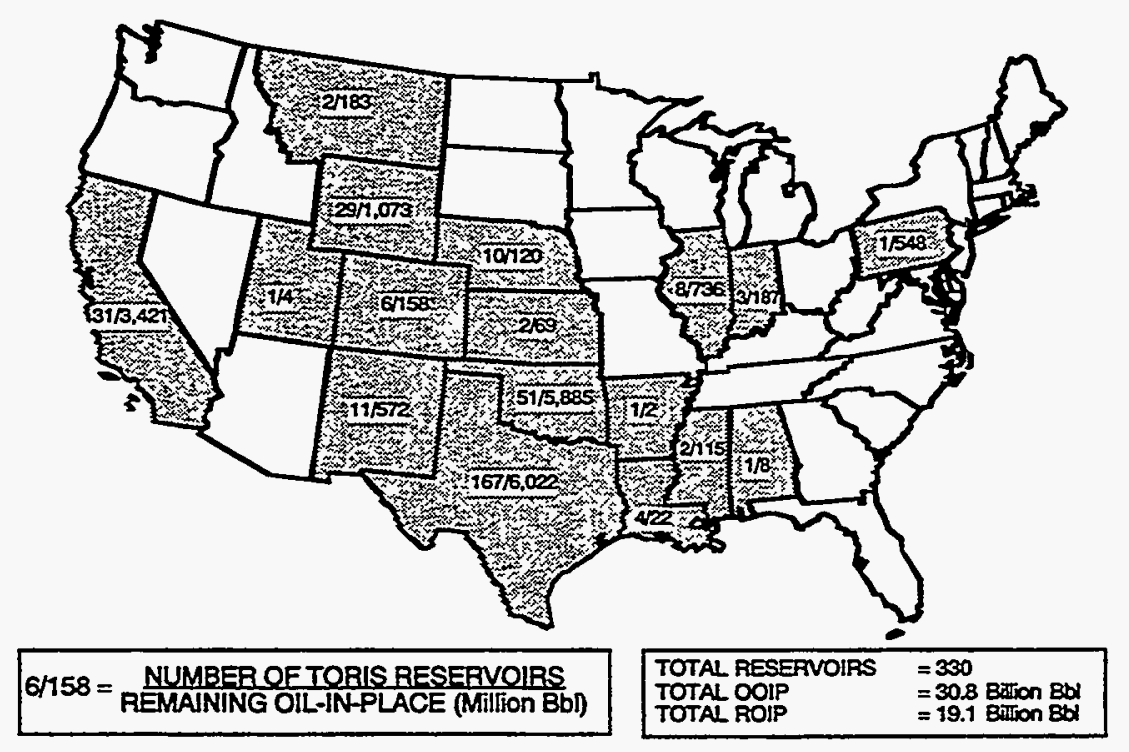

Figure 2.2 Distribution of Class 4 TORIS Reservoirs and Remaining OilIn-Place (Source: BPO TORIS, 1994) 


\begin{tabular}{|c|c|c|c|c|}
\hline & $\begin{array}{c}\text { NUMBER } \\
\text { OF } \\
\text { STATE }\end{array}$ & $\begin{array}{c}\text { ORIGINAL } \\
\text { OLIN-PLACE } \\
\text { RESERVOIRS }\end{array}$ & $\begin{array}{c}\text { CUMULATIVE } \\
\text { RECOVERY } \\
\text { MMO }\end{array}$ & $\begin{array}{c}\text { REMAINING } \\
\text { OILIN-PLACE } \\
\text { MMBO }\end{array}$ \\
\hline Alabama & 1 & 21 & 12 & 8 \\
\hline Arkansas & 1 & 3 & 1 & 2 \\
\hline Califomia & 31 & 4,790 & 1,322 & 3,421 \\
\hline Colorado & 6 & 241 & 82 & 158 \\
\hline Ilinois & 8 & 1,192 & 454 & 736 \\
\hline Indiana & 3 & 287 & 99 & 187 \\
\hline Kansas & 2 & 115 & 47 & 69 \\
\hline Louisiana & 4 & 109 & 59 & 22 \\
\hline Mississippi & 2 & 182 & 67 & 115 \\
\hline Montana & 2 & 339 & 152 & 183 \\
\hline Nebraska & 10 & 242 & 116 & 120 \\
\hline New Mexico & 11 & 701 & 124 & 572 \\
\hline Oklahoma & 51 & 10,071 & 3,757 & 5,885 \\
\hline Pennsylvania & 1 & 666 & 117 & 548 \\
\hline Texas & 167 & 10,184 & 3.933 & 6,022 \\
\hline Utah & 1 & 5 & 0 & 5 \\
\hline Wyoming & 29 & 1,608 & 524 & 1,073 \\
\hline TOTAL & 330 & 30,755 & 10,867 & 19,126 \\
\hline
\end{tabular}

\subsubsection{Heavy Versus Light Oil in Class 4 Reservoirs}

Most of the Class 4 oil resource represented in TORIS is light oil. Table 2.2 summarizes the oilin-place for the Class 4 reservoirs based on API gravity. About $80 \%$ of the original-oil-in-place, cumulative production, and remaining oil-in-place in these reservoirs is light oil, with gravity above $25^{\circ} \mathrm{API}$. The oil volumes in the medium gravity range (between $20^{\circ}$ and $25^{\circ} \mathrm{API}$ ) are almost as large as the heavy oil volumes (gravities below $20^{\circ}$ API) with each category accounting for approximately $10 \%$ of the total. Many of the medium gravity oil reservoirs could be targets for thermal recovery processes that have most commonly been applied to heavy oil reservoirs.

\subsubsection{Production and Operator Profile for Class 4}

Light and heavy oil production from the TORIS Class 4 reservoirs has dropped significantly since 1970, as shown in Figure 2.3. The total production from these reservoirs in 1970 averaged approximately 650,000 barrels of oil per day (BOPD), $6 \%$ of which was heavy oil. By 1991 , the total production had dropped to 145,000 BOPD, $14 \%$ of which was heavy oil. During this time, light oil production dropped from 610,000 to 125,000 BOPD, while heavy oil production dropped from 40,000 to 20,000 BOPD. Based on 1991 production volumes, just over half of the Class 4 production was operated by major oil companies, as shown in Figure 2.4. Medium and large 
( $666 \mathrm{I}$ 'SIROL Odg

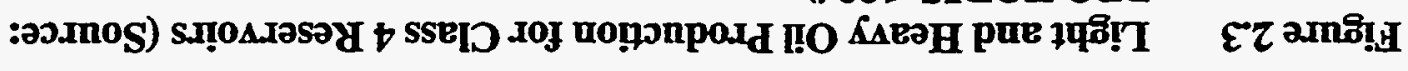

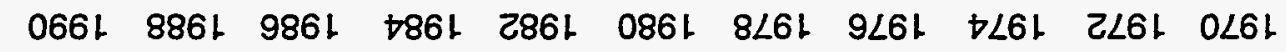

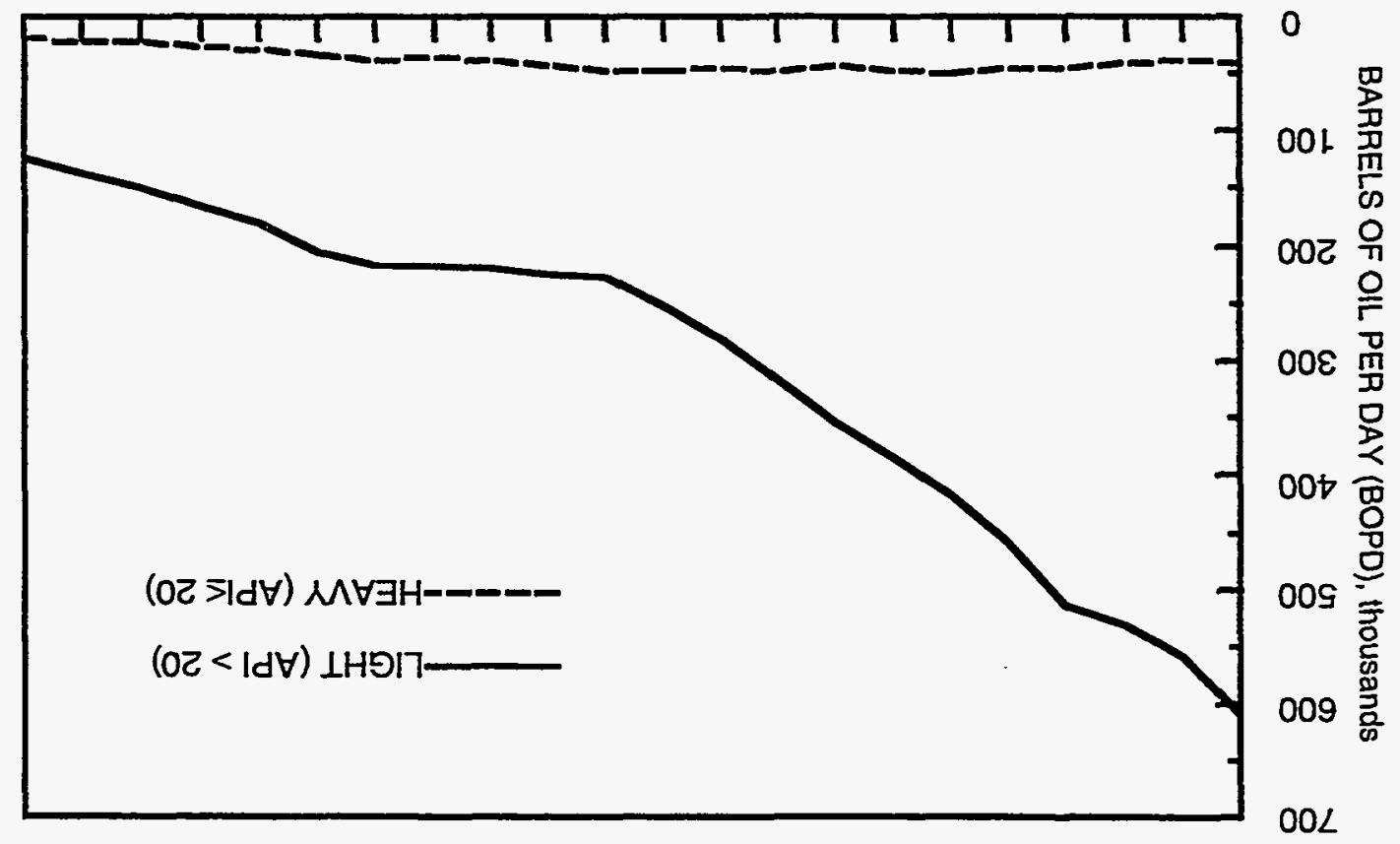

\begin{tabular}{|c|c|c|c|c|c|c|}
\hline & $9 Z I^{\prime} 6 I$ & & $\angle 98^{\circ} \mathrm{OL}$ & & SSLOOE & TVIOI \\
\hline ZI & SEZ Z & 8 & $0 \angle 8$ & oI & $\forall 9 I^{\prime} \varepsilon$ & (OZSIdV) XAVIH \\
\hline 6 & $\succsim \varepsilon L^{\prime} I$ & II & $\varepsilon 9 I^{\imath} I$ & OI & $866^{\mathrm{f}} Z$ & (sZSIdV>0Z) WRIGIN \\
\hline $6 L$ & $8 S I^{\prime} S I$ & I8 & $\$ \varepsilon 8^{\circ} 8$ & 08 & $\varepsilon 6 S^{5} \nabla \tau$ & $(\varsigma Z<I d V)$ IHOIT \\
\hline$\%$ & OGWW & $\%$ & Ognw & & \multirow[b]{2}{*}{$\begin{array}{c}\text { IdV } 0 \\
\text { XIN }\end{array}$} \\
\hline \multicolumn{2}{|c|}{$\begin{array}{l}\text { 3DVTd-NI-TIO } \\
\text { ONINIVNAR }\end{array}$} & \multicolumn{2}{|c|}{ 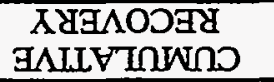 } & \multicolumn{2}{|c|}{$\begin{array}{l}\text { BDVId-NI-TIO } \\
\text { TVNORO }\end{array}$} & \\
\hline \multicolumn{7}{|c|}{ 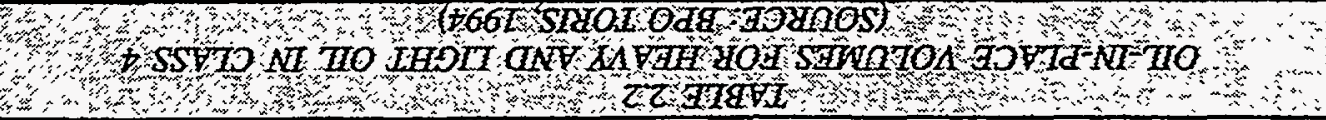 } \\
\hline
\end{tabular}

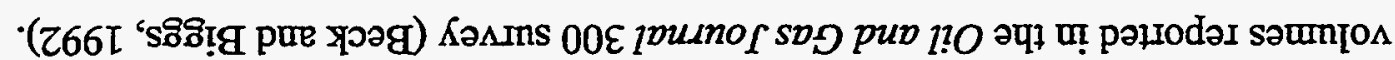

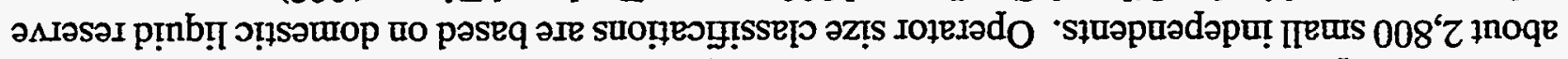

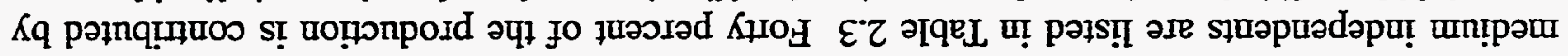

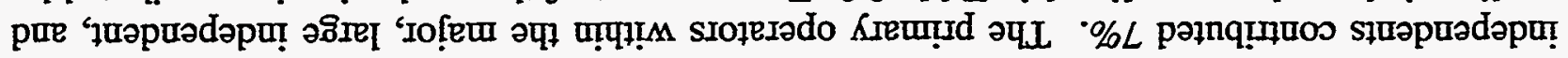




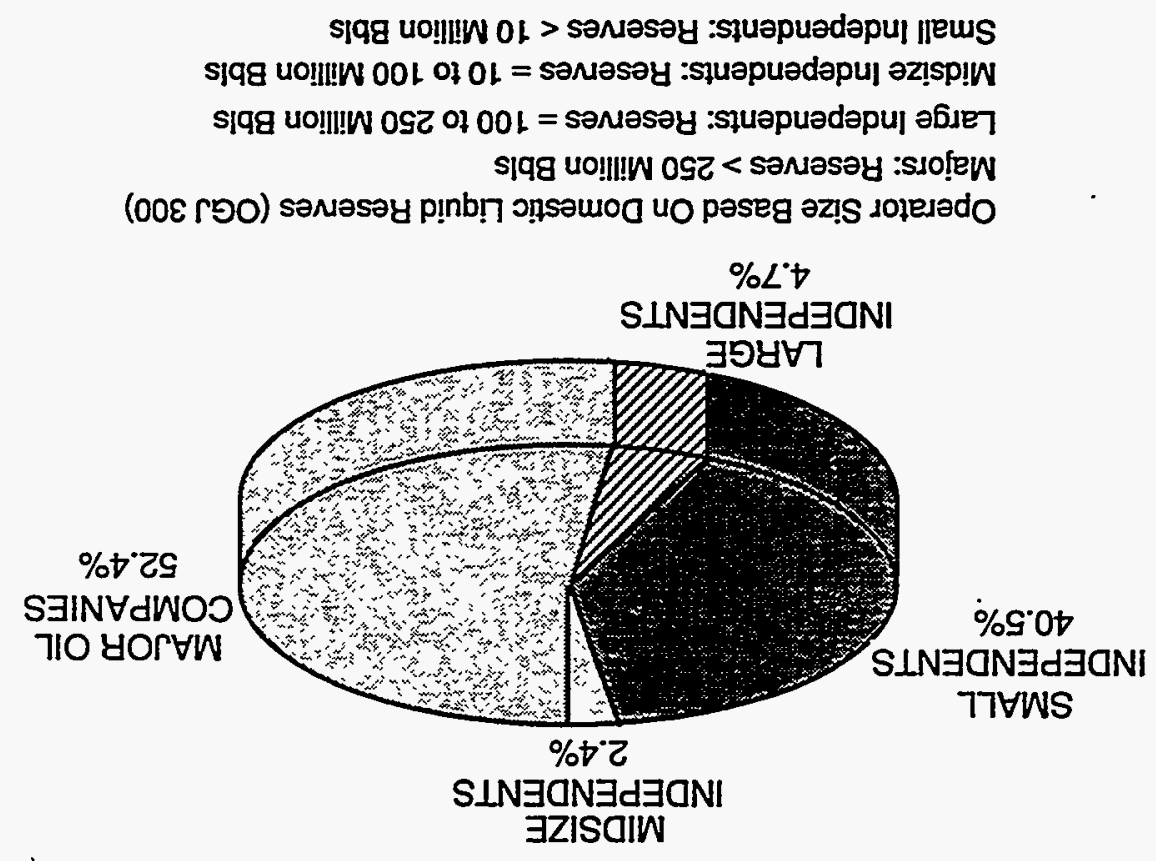




\begin{tabular}{|c|c|}
\hline \multicolumn{2}{|c|}{ 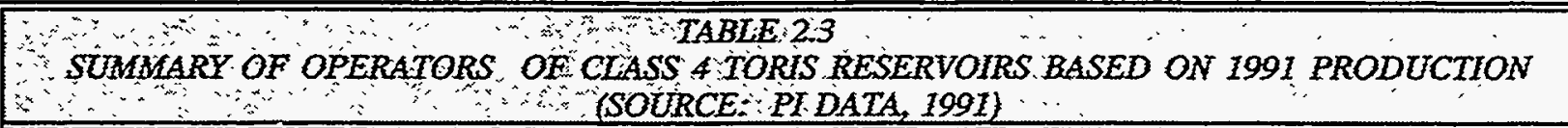 } \\
\hline OPERATOR NAME & $\begin{array}{l}\% \text { OF } 1991 \\
\text { CLASS } 4 \text { OIL } \\
\text { PRODUCTION }\end{array}$ \\
\hline AMOCO CORP. & 8.07 \\
\hline ARCO & 4.07 \\
\hline CHEVRON CORP. & 1.81 \\
\hline CONOCO INC & 1.08 \\
\hline EXXONCORP. & 3.73 \\
\hline USX-MARATHON GROUP & 8.00 \\
\hline MOBM CORP. & 12.06 \\
\hline ORYXENERGYCO. & 2.31 \\
\hline PHIIIIPS PETROLEUM $C O$. & 0.92 \\
\hline SHELL OIL CO. & 0.13 \\
\hline TEXACOINC & 8.58 \\
\hline UNOCAL CORP. & 1.68 \\
\hline $\begin{array}{l}\text { SUBTOTAL MAJORS } \\
\end{array}$ & 52.44 \\
\hline AMERADA HESS CORP. & 0.65 \\
\hline MERIDIAN OIL INC. & 0.06 \\
\hline MITCHEL L ENERGY \& DEVELOPMENT CORP. & 0.16 \\
\hline OCCIDENTAL PETROLEUM CORP. & 3.24 \\
\hline PENNZOIL COMPANY & 0.12 \\
\hline SANTAFE ENERGY RESOURCES INC. & 0.11 \\
\hline UNION PACIFIC RESOURCES CO. & 0.32 \\
\hline \begin{tabular}{|c|} 
SUBTOTAL LARGE INDEPENDENTS \\
\end{tabular} & 4.66 \\
\hline ADOBE RESOURCES CORP. & 0.00 \\
\hline AMAX OIL \& GAS INC & 0.11 \\
\hline AMERICAN PETROFINA INC & 0.24 \\
\hline AMERICAN EXXPLORATION $C O$. & 0.41 \\
\hline ANADARKO PEIROLEUM CORP. & 0.35 \\
\hline APACHE CORPORATION & 0.42 \\
\hline BHP PETROLEUM (AMERICAS) INC. & 0.03 \\
\hline CENEX & 0.03 \\
\hline COASTAL CORP. & 0.11 \\
\hline CONSOLIDATED NATURAL GASCO. & 0.13 \\
\hline ENRON CORP. & 0.00 \\
\hline HONDO O\&GCO. & 0.06 \\
\hline KERR-MCGEE CORPORATION & 0.15 \\
\hline MURPHY OIL CORP. & 0.08 \\
\hline NOBLE AFFULIATES INC. & 0.00 \\
\hline PACIFIC ENTERPRISES OIL \& GASCO. & 0.12 \\
\hline PARKER \& PARSLEY PETROLEUM $C O$. & 0.04 \\
\hline PRESIDIO OIL CO. & 0.09 \\
\hline SNYDER OIL CORPORATION & 0.00 \\
\hline SONAT INC. & 0.03 \\
\hline VINTAGE PETROLEUM & 0.01 \\
\hline SUBTOTAL MIDSIZE INDEPENDENTS & 2.41 \\
\hline SUBTOTAI SMALL INDEPENDENTS (ABOUT 2,800 OPERATORS) & 40.48 \\
\hline \multicolumn{2}{|l|}{ PERCENTAGES BASED ON 1991 PI DATA FOR TORIS CLASS 4 RESERVOIRS } \\
\hline \multicolumn{2}{|l|}{ RANKMNG BASED ON 1991 DOMESTIC LIOUIDS RESERVES (DLR), OGJ 300} \\
\hline $\begin{array}{l}\text { MAIORS: DLR > } 250 \text { MIILION BBLS } \\
\text { LARGE INDEPENDENTS: DLR }=100 \text { TO } 250 \mathrm{M} L L I O N \text { BBLS } \\
\text { MIDSIZE INDEPENDENTS: DLR }=10 \text { TO } 100 \mathrm{MIIION} \text { BBLS } \\
\text { SMALL INDEPENDENTS: DLR }<10 \text { MIIIION BBLS }\end{array}$ & \\
\hline
\end{tabular}




\subsection{General Geologic Characteristics of Class 4 Reservoirs}

An adequate knowledge of the range of expected reservoir-unit geometries and their attendant internal variations in fluid retention and flow properties is necessary to efficiently develop and exploit any petroleum reservoir. This knowledge becomes more critical for recovering remaining oil-in-place after reservoirs approach their economic limits under current operations.

Reservoir-unit geometries and their internal patterns of heterogeneities affecting fluid flow are related in predictable, though as yet imperfectly understood, ways to the geological factors and processes controlling deposition and preservation of Class 4 strandplain/barrier island deposits. An understanding of the fundamental geological factors/processes and their interactions will make geometry of reservoir units and their accompanying internal heterogeneities more predictable and exploitation of Class 4 reservoirs more efficient.

The following discussion includes (1) the general depositional characteristics of Class 4 reservoirs and the specific depositional characteristics that distinguish Class 4 reservoirs from other reservoir classes; (2) the geological factors that control, through their interaction, the distribution and geometry of the sedimentary deposits that make up Class 4 reservoirs; and (3) the major known depositional heterogeneities that can affect interwell-scale fluid flow in Class 4 reservoirs. For the reader unfamiliar with geological terminology commonly associated with strandplain/barrier island systems, a Glossary of Geological Terms (Appendix A) is provided.

\subsubsection{Strandplain/Barrier Island Deposition}

Reservoirs classified as strandplain/barrier island reservoirs (Class 4) are shoreline-associated deposits resulting from redistribution by marine processes (e.g., waves, tides, currents) of sediments derived from terrigenous sources. Specifically, sediments found in Class 4 reservoirs arrived at the site of deposition largely through transport by longshore currents. Class 4 reservoirs are not immediately associated with deltaic sediments of major rivers. Class 4 reservoirs are, however, often located along depositional strike not far from such deltas.

A play is a grouping under a common name of reservoirs within a continuous geographic area that produce from a similar stratigraphic interval. All reservoirs within a given play do not necessarily have the same depositional origin. The name given to a play often reflects some combination of the following: name or geologic age of the producing stratigraphic interval; name of a predominant field in the play; or the dominant depositional environment or lithology.

Because of the emphasis placed on geographic location and producing stratigraphic interval, plays often contain reservoirs of more than one depositional origin, i.e. reservoirs belonging to different TORIS classes. Therefore, some plays appearing in figures and tables of this report may be dominated by reservoirs not included in Class 4 , and this fact may be reflected in the play name. These plays have been included because they contain at least some Class 4 reservoirs. Summary statistics apply only to the Class 4 reservoirs contained in the play. 


\subsubsection{Depositional System Classifications}

The strandplain/barrier island category of reservoirs includes variations of and subsets of the following deposit types:

\section{Strandplain}

A prograded shore built seaward by waves and currents, continuous for some distance along the coast.

In essence, this is the deposit left behind by a series of beaches or strandlines prograding seaward with time. The general geometry of strandplain deposits forming in sand-rich and mud-rich environments is shown in Figure 2.5A and Figure 2.5B, respectively. Modern sand-rich strandplain deposits along the Mexican Gulf Coast (i.e., the Nayarit and Tabasco coastal plains) have been described by Curray et al. (1969) and Psuty (1967). Mud-rich modern strandplains occur along the southwest Louisiana coast and along the adjacent parts of the northeast Texas coast. These deposits have been described by Fisk (1955), Beall (1968), Friedman and Sanders (1978), and Otvos and Price (1979).

An important distinction between mud-rich and sand-rich strandplain deposits is that sand-rich deposits display sand continuity in both depositional strike (shoreline parallel) and dip (shoreline perpendicular) directions, while sands in mud-rich deposits are not continuous in the dip direction (Tyler and Ambrose, 1986). No lagoonal deposits are involved, because waves have moved sediment directly up to the shoreline. Many deposits classified as strandplains may contain at least some evidence of barrier island deposition.

\section{Barrier Island}

A long, low, wave-built sandy (or coarser-grained) island, parallel to the shore and exposed above high tide, commonly with dunes, vegetated zones, and swampy terrain. These islands shelter the coast and isolate shore waters in a lagoon between the shoreline and the island. General features of a barrier island deposit are depicted in Figure 2.5C.

Barrier islands are also referred to as offshore barriers, offshore bars, barrier bars, offshore beaches, shoreline barriers, and as barrier beaches. Depending on basin, shoreline, and current configurations, barrier islands may become or evolve from barrier spits or peninsulas which are connected to the land at one end. The modern southeast Texas coast contains numerous examples of barrier island deposits. Bernard et al. (1978) give a good overview of these modern deposits, and a more detailed treatment may be found in McGowen et al. (1977).

This reservoir category also includes longshore bars which are very similar in that they are elongated and shore parallel, but are submerged at high tide. Longshore bars are also built by waves and are essentially ridges, mounds, or banks of sand or gravel. As in the case of barrier islands, local configuration of shorelines and currents may affect the orientation and geometry of longshore bars. 


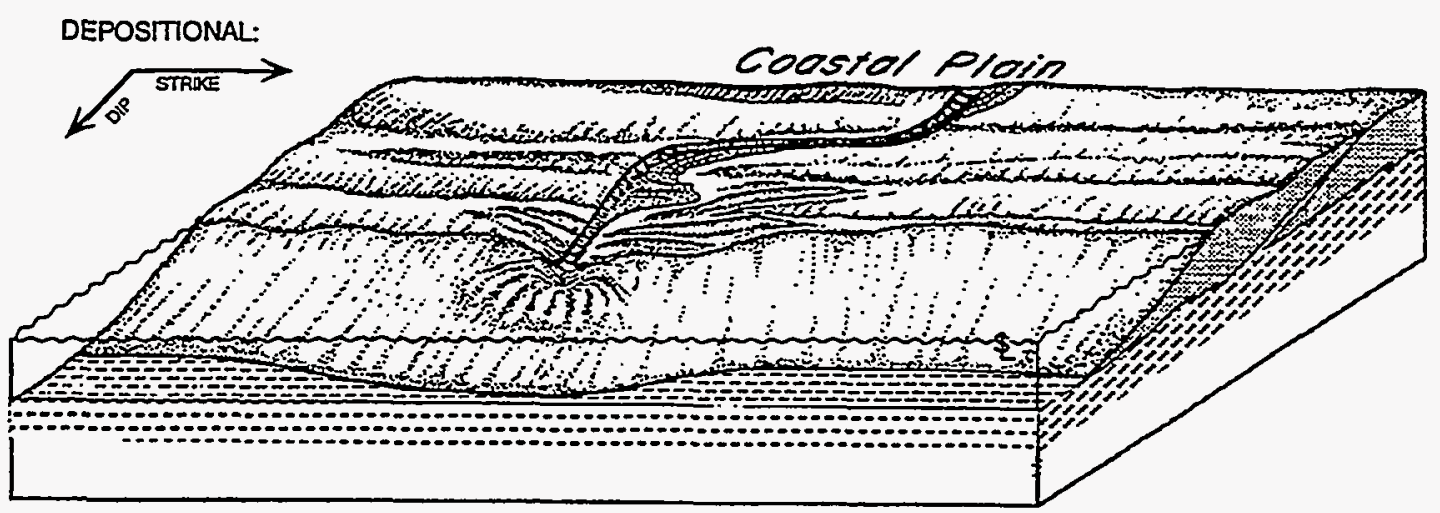

A. SAND-RICH STRANDPLAIN

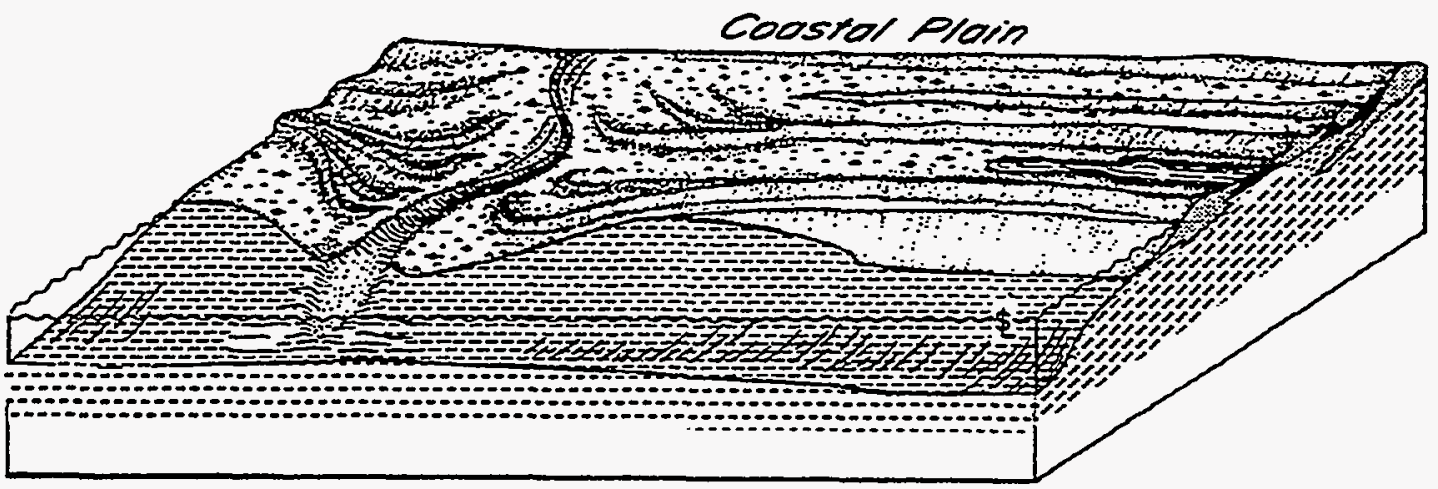

B. MUD-RICH STRANDPLAIN (CHENIER PLAIN)

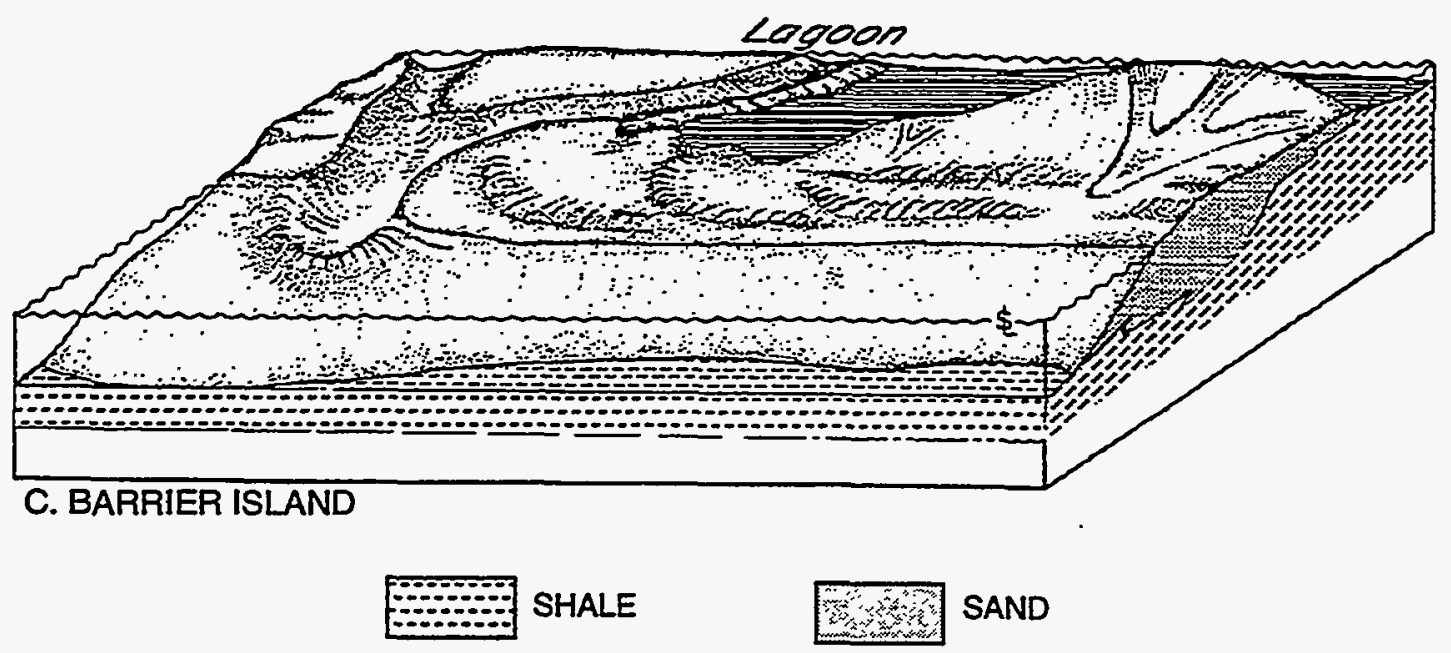

Figure 2.5 Generalized Geometry of Strandplain/Barrier Island Depositional Environments (Source: Galloway, 1986, reprinted by permission) 


\subsubsection{Depositional Processes}

The interaction of numerous geologic processes controls the location, size, internal and external geometry, and quality of reservoir rocks in strandplain/barrier island reservoirs, but sediment deposition is controlled primarily by marine processes (i.e., wave action, tidal action, longshore currents).

In strandplain/barrier island deposits, sediment may be supplied to some extent by wave erosion of locally exposed rocks or sediments. In most instances, however, longshore transport of sediment eroded elsewhere along the coast, often derived from deltas and delivered by longshore currents, prevails as a sediment source.

Waves of normal energy moving toward the shoreline across a shallow shelf begin to lift and move bottom sediment as they near the shoreline. The water depth at which this occurs is referred to as normal wave base. This wave action provides for (1) winnowing or sorting of sediment grains as fines are carried away by continuing longshore currents, (2) size reduction and rounding of grains accompanied by effective removal of mineralogically unstable (chemically and physically less resistant) grains, and (3) shoreward movement of sediment. Shoreward movement and vertical accretion or "piling up" of coarser grains places them in a shallower environment where they receive yet more energy and the process repeats. Eventually the deposit becomes emergent and the prevailing wind, which supplied the energy to drive waves, acts directly on the sediment grains themselves resulting in subaerial dune formation.

In certain instances, depending on receiving basin geometry and shoreline configuration, longshore currents may be augmented by tides, but in general, tidal processes result in water movement perpendicular to the shoreline. When offshore barrier islands or longshore bars are involved, tidally influenced water movements tend to concentrate in specific small channels cut through the wave-built bar or barrier. These tidal inlets are characterized by currents that reverse direction with the tide, and the sediments found there reflect the high variation in energy levels accompanying these directional shifts. The relative geometries of tidal inlet and associated deposits with respect to the barrier island complex are depicted in Figure 2.6. Tidal currents flowing back and forth through tidal inlets also carry sediments and may form tidal deltas on both the landward (flood tidal delta) and seaward (ebb tidal delta) side of the inlet. Tidal deltas deposited on the seaward side are usually reworked by wave action. Tidal inlets tend to migrate laterally with time.

Storm surges or abnormal rises in sea level along a shoreline caused by low atmospheric pressure or prolonged and strong onshore storm winds can enhance the effects of waves and tides. High water levels and much-increased intensity of wave action can cause severe erosion of subaerial deposits and even breaching of barrier islands resulting in deposition of washover-lobes of sediment on the lagoonward side. Tidal currents can become particularly strong when the water mass piled along the shoreline suddenly ebbs after a storm surge event. Cutting of new inlets and deepening or lateral migration of existing inlets may result. 


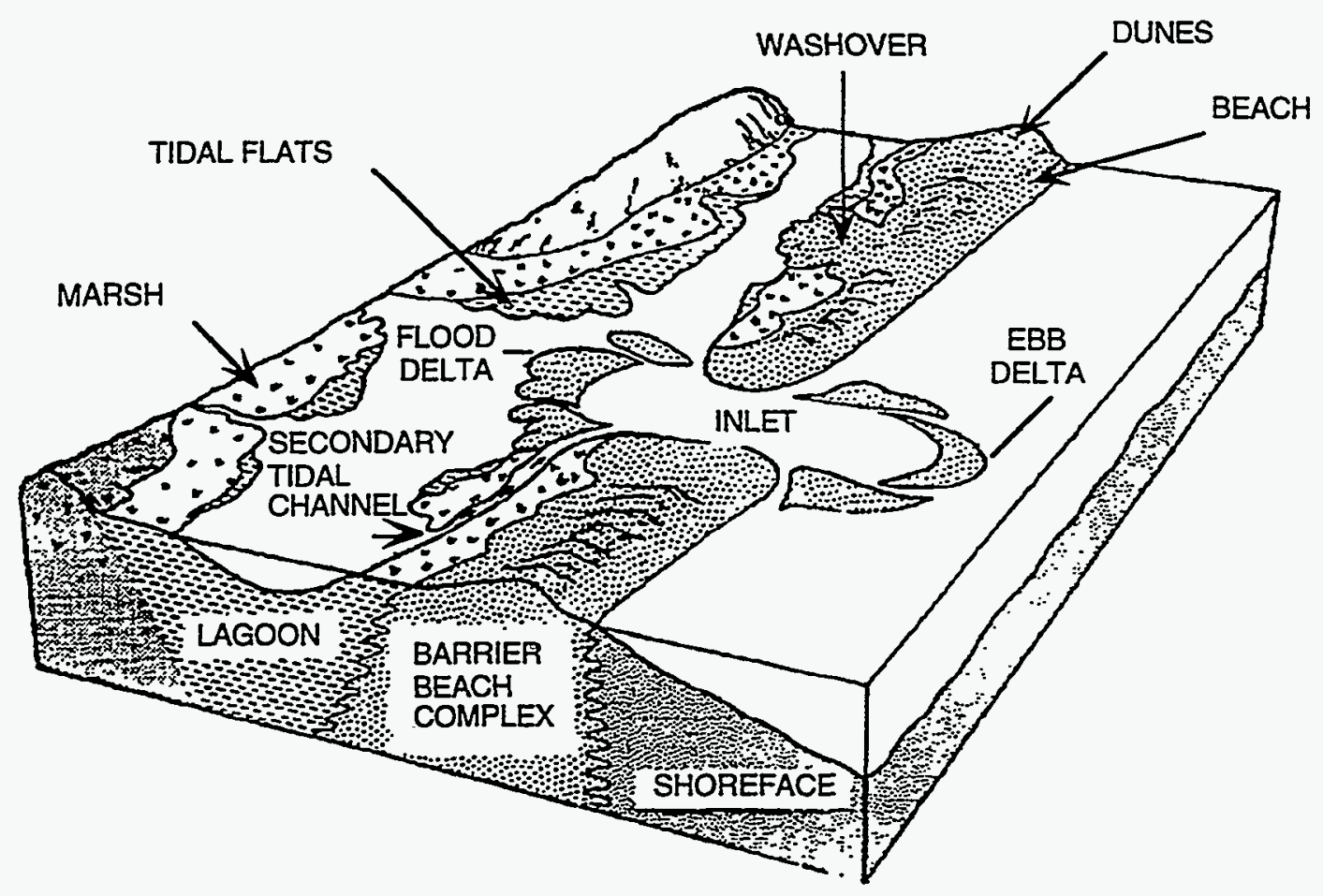

Figure 2.6 Generalized Geometry of Tidal Inlet and Associated Deposits in Barrier Island Complexes (Source: Moslow, 1984, reprinted by permission)

\subsubsection{Facies Description}

The literature contains a wide variety of classification schemes for strandplain/barrier island facies. The discussion presented in this document is a simplification and synthesis of schemes based on depositional origin of major lithologic units taken from Coleman (1976) and Friedman and Sanders (1978).

The discussion of facies includes those normally found in association with strandplain deposits as well as those unique to the barrier island sequence. The generalized progradational sequence of facies is shown in Figure 2.7.

\section{Marine Shelf Shale}

The marine shelf shale facies may contain some stringers of silt and/or poorly sorted sand, may become less shaly near its contact with overlying distal bar facies, and may contain scattered shells or thin shell layers. It usually shows ample evidence of marine burrowing organisms.

These sediments represent deposition under normal marine shelf conditions below normal (day to day) wave base. Occasional influxes of coarser sediments are transported by longshore currents or dumped by ebb tidal currents and/or wave action during extreme storm events. This facies characteristically has no reservoir potential, but can act as a barrier to fluid flow. 


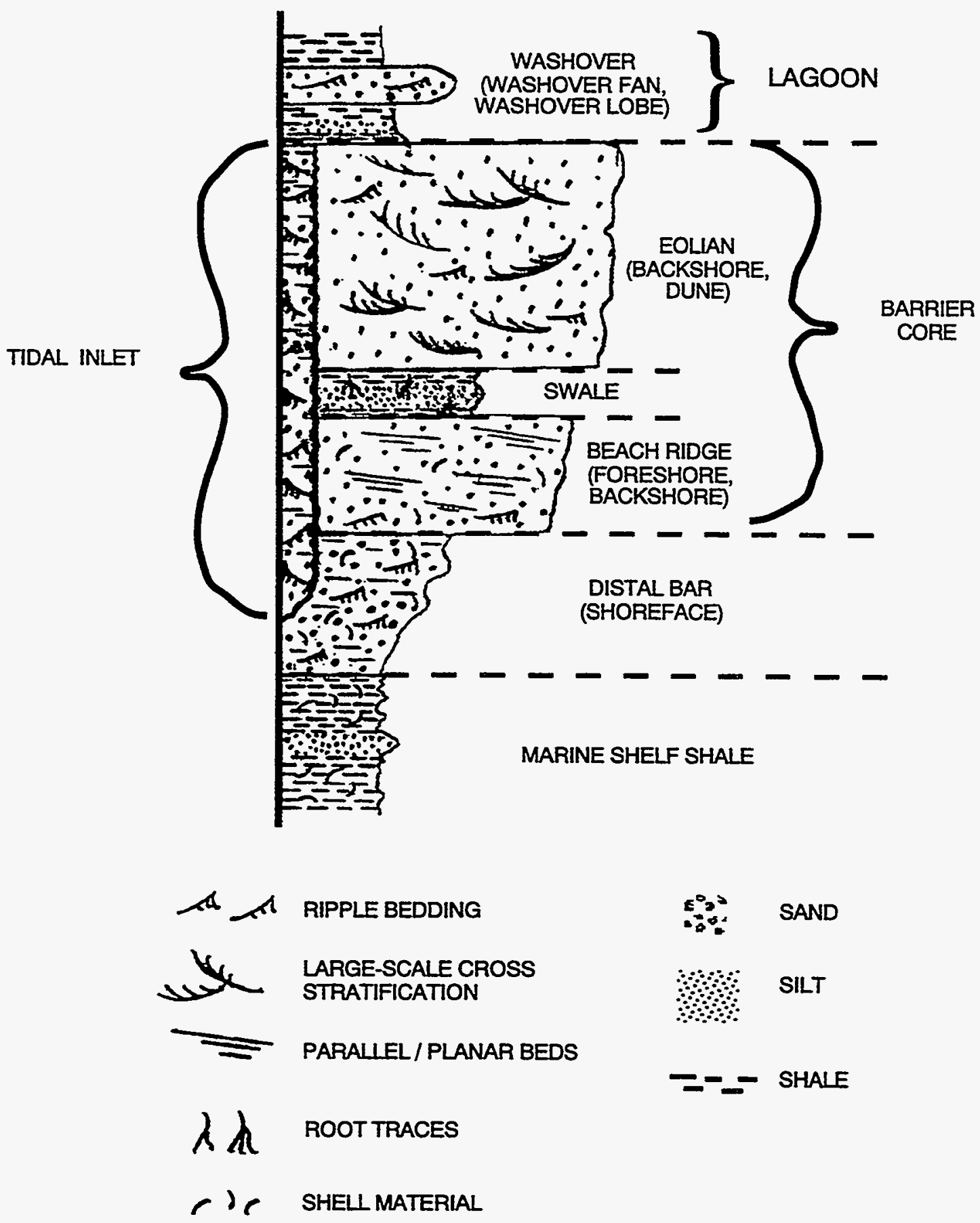

Figure 2.7 Strandplain/Barrier Island Facies Terminology and Generalized Vertical Sequence for a Prograding Shoreline (Modified from: Coleman, 1976) 


\section{Distal Bar}

The distal bar facies (also referred to as shoreface or fore-barrier sands) contains silt, sand, and shale layers. Sands may show some internal grading and common small-scale cross stratification. The facies displays an increase in grain size vertically and may contain scattered shells.

Sediments are deposited increasingly within storm and normal wave base. These sediments, which reflect much higher depositional energy than the underlying marine shelf shale facies, are being deposited and worked by waves on the seaward side of the longshore bar, barrier island shoreline, or mainland shoreline. A vertical increase in sand reflects shallowing of water depth and higher energy as the bar crest or beach progrades.

This facies can be expected to have some reservoir quality sands, especially near its upper contact, but sand units are generally thin and areally discontinuous.

\section{Barrier Core}

\section{A. Beach Ridge}

The beach ridge facies (also referred to as foreshore and backshore sands) has clean well-sorted sands in massive beds or parallel (planar) beds with low-angle seaward dips. Some small-scale cross-stratification may occur near its lower contact with the distal bar facies. Some shell and heavy mineral layers may be present.

This is the highest-energy facies deposited by water in the strandplain/barrier island system. Near-emergent to emergent conditions are represented. Breaking waves provide ample energy to sort and abrade grains.

This facies, along with the often overlying eolian facies, discussed below, constitutes the best reservoir rock associated with strandplain/barrier island systems.

\section{B. Swale}

Often containing poorly sorted, thinly bedded silt and shale units with root traces, this facies may occur at any level in the subaerial part of the sequence.

These sediments are representative of deposition in low energy interdune areas on the subaerially exposed part of a barrier island or strandplain deposit. Topographically low areas allow sediment trapping and stabilizing vegetation to become established where moisture collects.

These units form effective but local barriers or baffles to fluid flow.

\section{Eolian}

The eolian facies (also referred to as backshore and dune sands) consists of clean well-sorted sands in massive beds or in large-scale festoon cross-beds. 
This facies consists of sediments derived primarily from the beach ridge discussed above and deposited subaerially by onshore winds. Further abrasion and sorting of sedimentary grains takes place in this environment. This facies, along with the underlying beach ridge facies, constitutes the best reservoir rock associated with strandplain/barrier island systems.

\section{Lagoon}

The lagoon facies contains poorly sorted silts and clays with scattered sand-size particles of wind-blown quartz and erratically distributed thin stringers of moderate-to-well-sorted quartz sand. The fauna often indicate brackish or restricted conditions.

These sediments reflect deposition in shallow water (10-30 feet) under protection from the open sea by the barrier island itself. Salinity in lagoonal waters is a function of climate, presence of local streams and rivers on the mainland, and the effective isolation from the sea produced by the barrier island complex. Scattered silt- and sand-size grains are wind-blown from the subaerially exposed sediments of the barrier island; sand stringers may be storm washovers or flood tidal deltas.

In a strandplain or related environment where no lagoonal sediments are present, the lagoonal facies position in the stratigraphic sequence may be occupied by salt- or fresh-water marsh deposits depending on local climate, fresh water supply, and sediment availability.

Washover lobe and flood tidal delta sediments have some potential as reservoirs, but sand quality cannot be expected to be consistent, and the sands are thin, erratically distributed, and not continuous over long distances.

\section{Tidal Inlet}

Tidal inlet deposits generally consist of one or more fining-upward sequences with sand and shell materials in lower cross beds and/or ripple beds (either of which may be bidirectional) grading upward to finer sands and silt- or clay-size sediments; shale drapes are common (Moslow, 1984).

Content varies depending on relative strengths of wave versus tidal energy in the environment (Moslow and Tye, 1985). High relative wave energy will result in coarser, better-sorted inlet fills with lesser amounts of shale overall. If tidal energy predominates, less sorting takes place, overall grain size is smaller, and shale content will be much higher.

The reservoir quality of the tidal inlet facies is relatively greater under conditions where wave energy is greater. The amount of fines in tidal inlet sediments is less under these circumstances, and the facies will act less like a flow barrier.

Relative geometries of sand bodies formed by the facies discussed above in a typical barrier island system having low tidal energy are shown in Figure 2.8. Tide-related facies are well represented volumetrically in spite of low tidal energy, because of the tendency for tidal inlets to migrate laterally with time. 


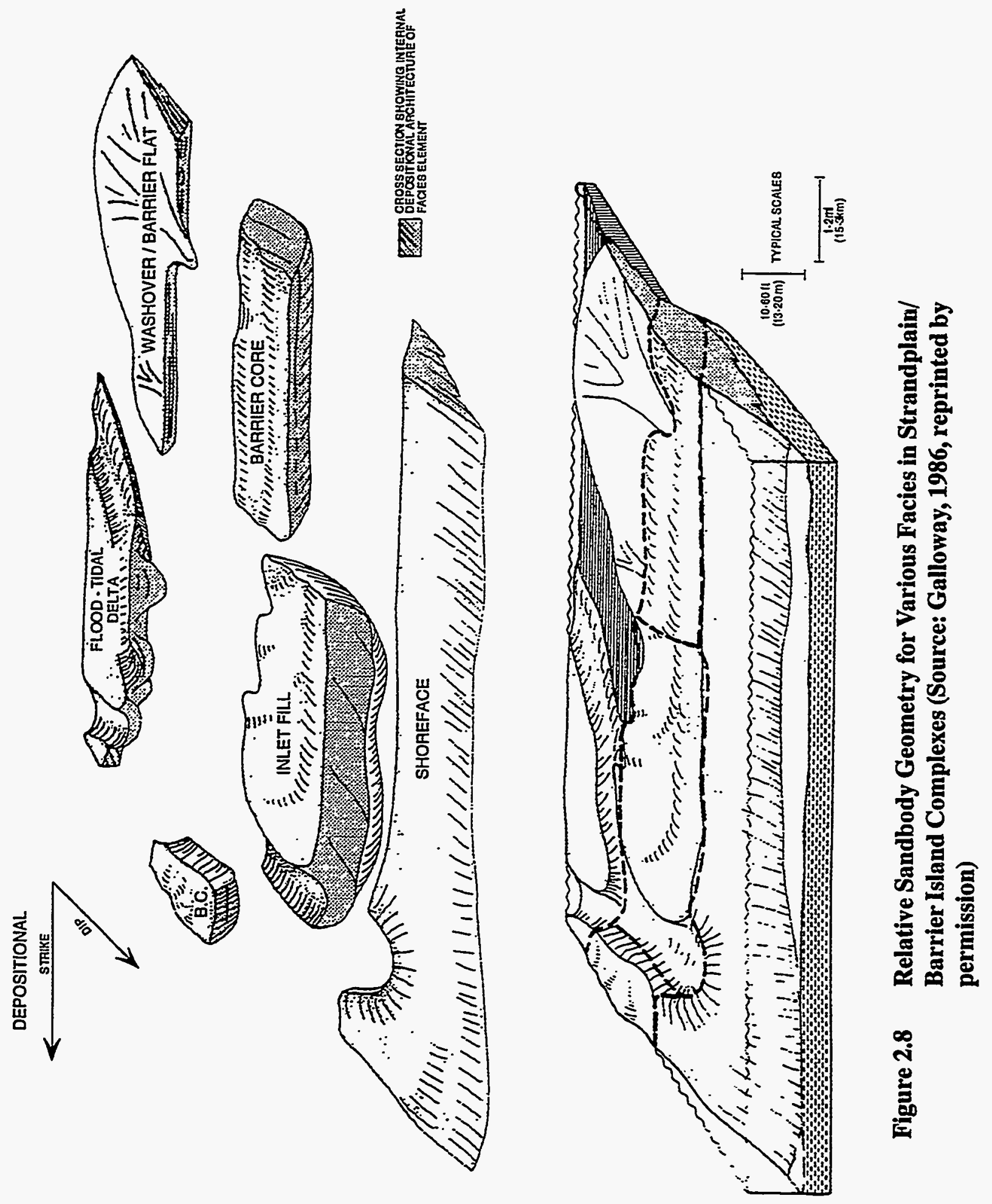




\subsubsection{Geologic Controls on Reservoir Architecture and Properties}

A number of geological and paleogeographical factors working in combination control the location, size, internal and external geometry, and reservoir properties of strandplain/barrier island deposits. Although the effects of each of the factors cannot be isolated, their individual influences have been determined through numerous studies of strandplain/barrier island and related deposits in both modern and ancient environments.

Post-depositional erosion and emplacement of overlying sediments have the potential to impart modifications to strandplain/barrier island deposits that critically change reservoir geometry and internal fluid flow patterns.

\subsubsection{Key Geologic Factors and Their Independent Effects}

\section{Sediment Supplied from Land}

The chemical/mineralogical composition of the materials incorporated into strandplain/barrier island deposits is an important factor. The type of material available is a function of (1) the ultimate source of the material and (2) alteration of the material during transport.

The source area (or provenance) of land-derived material is the primary factor determining composition and, in some cases, sediment grain size. Sediments derived from a volcanic source have the potential for being vastly different from those derived from erosion of clean well-sorted quartz sandstone. Transport from the source area by wind, water, or ice, and the distance and duration of transport can also have a major influence on size, composition, and volume of available material.

Size reduction, sorting, and rounding of sedimentary material are usually thought of as being the main sediment characteristics that are modified through transport, but selective abrasion and chemical weathering of less mineralogically stable grains is an equally important modification. The effective removal of less stable grains will generally lead to a lesser degree of mineralogic alteration and redistribution of materials during burial diagenesis.

The volume of sediment available will have a profound effect on the dimensions and geometry of strandplain/barrier island deposits both directly as a sediment accommodation consideration and indirectly as it may result in tectonic subsidence at the shoreline.

\section{Longshore Currents}

Longshore currents are the final-stage sediment delivery mechanism for Class 4 reservoirs. These reservoirs are, by definition, not immediately associated with large river systems and deltas; although strandplain/barrier island reservoirs may be along depositional strike from such deltas. The strength and direction of these currents will control the volume of sediment available at the site of strandplain/barrier island deposition. Longshore currents may owe their origin to waves (which are in turn wind-driven), tides, or other water movements, and the interaction of water movement with basin/shoreline geometry. Longshore currents may be strongly augmented under storm surge conditions. 
The volume of sediment delivered by longshore transport will be a major factor influencing the geometry and dimensions of strandplain/barrier island deposits. Longshore currents can also contribute to sorting and rounding of grains.

\section{Wave Energy}

Wave energy is the primary factor responsible for the formation of strandplain/barrier island deposits. Waves are responsible for (1) removal by abrasion of less resistant (usually mineralogically unstable) grains, (2) sorting, rounding, and reduction in size of remaining stable grains, and (3) physical movement of sediment from deeper water in front of the deposit to a shallow water or subaerial position.

Normal day-to-day levels of wave energy have the most influence on the overall internal and external geometry of the deposit, but extraordinary wave energy accompanying storm surges may be responsible for reworking upper parts of the deposit into washover lobes on the landward or lagoonward side.

\section{Tidal Energy}

Tidal energy, which is a function of tidal range, is a key modifying factor in forming strandplain/ barrier island deposits. Sediments moved back and forth by tidal currents may experience some additional sorting and abrasion, but the most important effect of tidal energy is to maintain and create localized breaches in the wave-constructed barrier and to fill those breaches with sediments of generally lesser reservoir quality.

High relative tidal energy tends to divide the wave-deposited reservoir into numerous lateral compartments (Figure 2.9A). Under conditions where wave energy dominates, lateral compartmentalization will be much less and tidal deposits will be mostly limited to ebb tidal deltas (Figure 2.9B).

\section{Tectonics}

Relative tectonic movements are extremely important controls on the formation of strandplain/ barrier island deposits. Tectonic movements associated with the sediment source and transport areas will strongly influence topography and the relative amounts of chemical/mechanical abrasion of sediments during transport. Utimately these movements will affect the composition, grain size, and volume of sediment arriving at the site of strandplain/barrier island deposition. Tectonic movement affecting the strandplain/barrier island deposition site can have a marked effect on the external geometry of the deposit. Subsidence, resulting from the weight of accumulating sediment or other causes, allows accommodation room for sediments and tends to inhibit seaward progradation. 

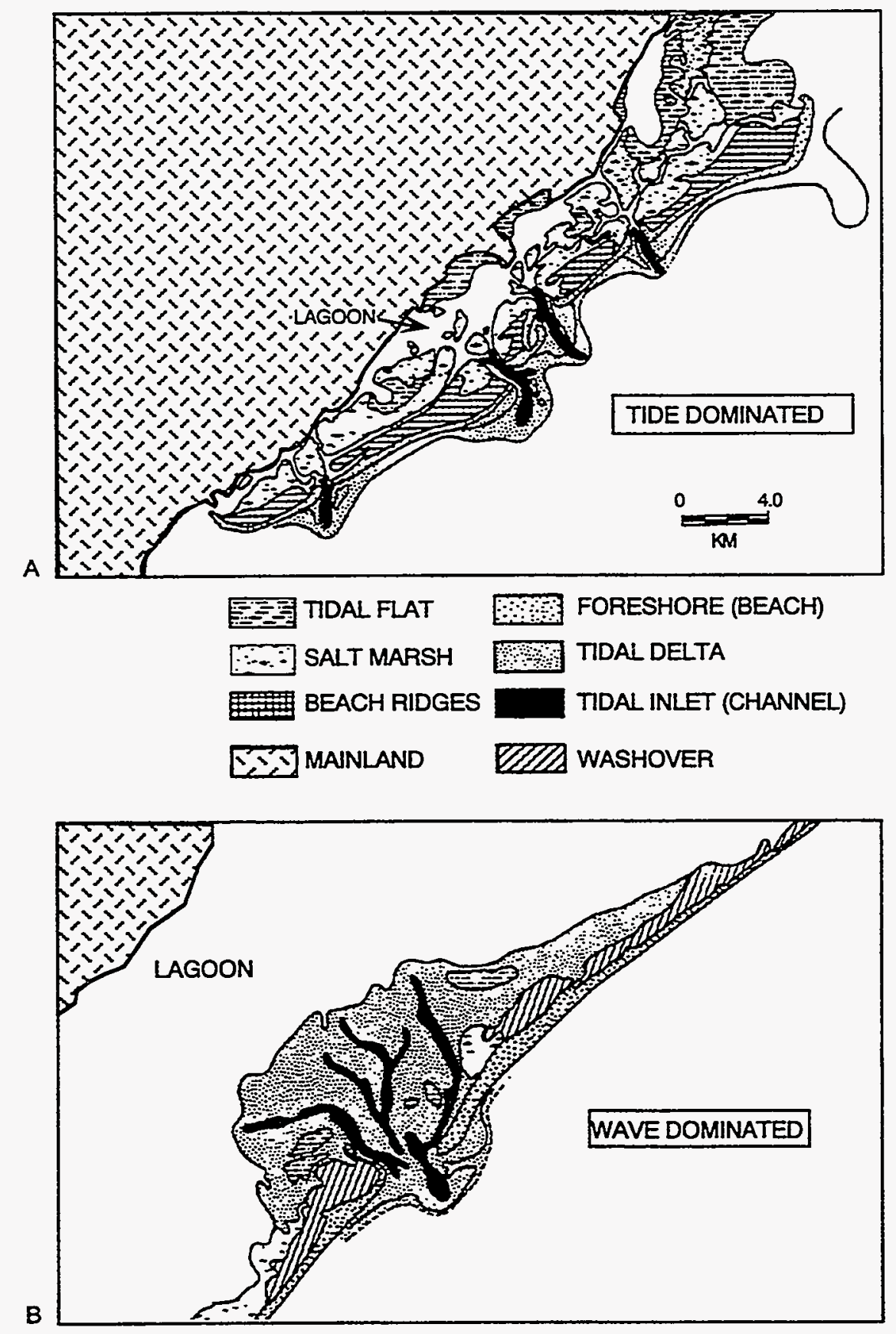

Figure 2.9 Distribution of Depositional Environments Associated with Barrier Islands and Tidal Inlets in Wave-Dominated and Tide-Dominated Shorelines (Modified from: Moslow, 1984, reprinted by permission) 


\section{Slope Angle of the Nearshore Shelf}

On shallow, low-sloping shelves, wave energy becomes capable of suspending and moving bottom sediments well seaward of the shoreline, thus favoring development of longshore bars or barrier islands in front of the coastline. On steeper-sloping shelves, wave energy affects bottom sediments only a very short distance from the coast. Under such circumstances, development of shoreline beaches and strandplain deposits is favored.

\section{Eustatic Sea Level Fluctuation}

Independent changes in worldwide eustatic sea level have effects on strandplain/barrier island deposits that are indistinguishable from shoreline-associated tectonic effects. A eustatic sea level rise has the effect of tectonic subsidence; a sea level fall has the same effect as a tectonic uplift.

\section{Climate}

Climate is an influential factor controlling (1) the sediment type and amount supplied from the source area, (2) abrasion of grains (particularly chemically/mineralogically unstable grains) during transport, and (3) wind and wave direction and magnitude at the site of deposition.

\subsubsection{Interaction of Geologic Factors}

None of the factors discussed above has a unique expression in strandplain/barrier island architecture or reservoir properties. Even a simple factor like the slope of the nearshore shelf must be weighed against the relative energy of normal waves to predict whether sand bodies will develop at the shoreline or offshore. Factors may work in conjunction or in opposition to produce the depositional characteristics found in strandplain/barrier island reservoirs. Some factors express their effects only if they strongly dominate over other opposing factors.

\section{Interaction of Sediment Supply, Sea Level, and Tectonics}

The volume of sediment (from nearby streams/rivers, from longshore transport, or from nearby shoreline erosion), change in eustatic sea level, and relative tectonic movement associated with the shoreline work together to determine the external geometry of strandplain/barrier island-related deposits.

High volume of sediment input, falling sea level, or a tendency toward tectonic stability near the shoreline favor a seaward migration of strandplain/barrier island facies with time resulting in a progradational architecture (Figure 2.10A). In this architecture, good reservoir quality barrier core facies along with their attendant fluid flow heterogeneities are well preserved. 
Approximately stable conditions of relative sea level, sediment supply, and relative tectonic movement can result in a vertical stacking of strandplain/barrier island facies in an aggradational architecture (Figure 2.10B). Mutually offsetting magnitudes of sediment supply, subsidence, and sea level change may also give rise to an aggradational architecture. Under aggradational circumstances, good reservoir-quality facies may be volumetrically significant. Lack of reworking preserves internal fluid flow heterogeneities such as tidal inlet fills and swale deposits as well as the best reservoir facies.

Rising sea level, rapid nearshore subsidence, or a very limited sediment supply tend to produce a transgressive architecture (Figure 2.10C). Any one of the above conditions can result in this facies architecture if the condition is sufficiently pronounced. In a transgressive strandplain/barrier island architecture, the maximum energy facies are very limited in volume compared with other facies and an exposed eolian or dune facies may never develop. Reworking of sediments may virtually destroy high energy potential reservoir facies. Potential reservoir volume is comparatively small.

\section{MICROTIDAL BARRIER-ISLAND DEPOSITIONAL ARCHITECTURE}

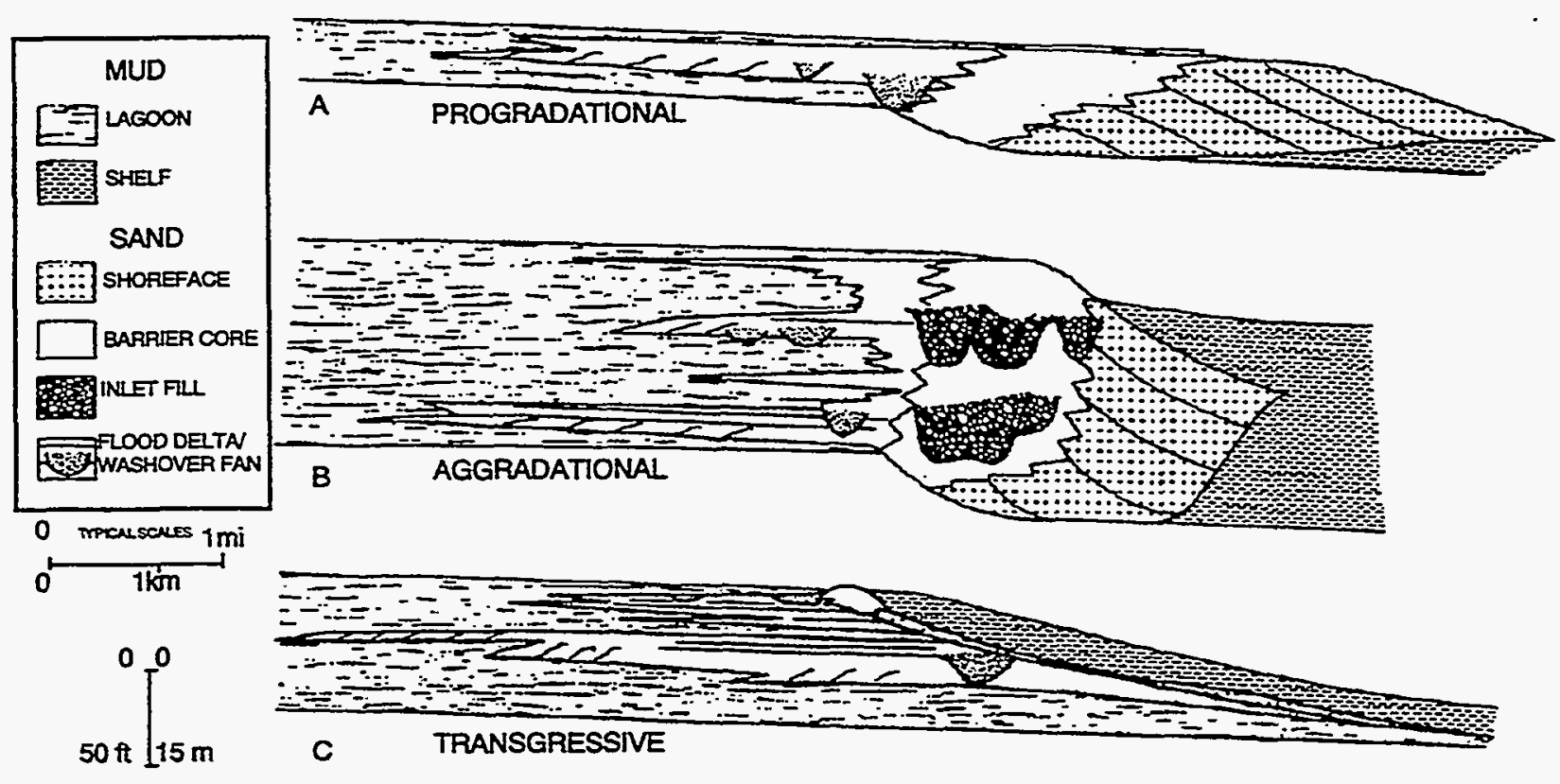

Figure 2.10 Examples of Microtidal Barrier Island Depositional Architecture (Source: Galloway, 1986, reprinted by permission) 


\section{Interaction of Waves and Tidal Currents}

Relative energies of wave versus tidal processes play a large part in determining the internal facies geometry of strandplain/barrier island deposits. Under conditions where wave energy greatly predominates, almost no tide-associated deposits (e.g., tidal inlet fills, tidal deltas) will be preserved; such deposits are quickly reworked by wave action. If wave energy is less than tidal energy, the better wave-built reservoir facies and possible associated eolian facies will be compartmentalized by tidal inlets. In general terms, the higher the tidal energy with respect to wave energy, the more frequent and better developed tidal inlets will be. In an environment where tidal energy is extremely high with respect to wave energy, strandplain/barrier island deposits cannot form at all.

\subsubsection{External and Internal Dimensions of Strandplain/Barrier Island Features}

The external dimensions of strandplain/barrier island systems will be a direct function of the complex interaction of the geologic processes that lead to their formation. Examination of modern day deposits can, however, give some indication of probable dimensions we might expect to find under similar circumstances in the geologic past. Using, as a simplified model, barrier islands of the modern Gulf Coast, sand bodies in the range of 20 to perhaps 50 feet in thickness might be expected (in some cases an additional 30 to 40 feet for optimal development of eolian sediments could be added). Widths of the features might be expected to be from 1 to a few miles probably averaging 2 to 4 miles, and length along depositional strike might be from a few to as much as 50 miles (averaging 10 to 25 miles) (Galloway, 1986; Penland et al., 1985; Coleman, 1976).

The probable dimensions of sediment bodies of strandplain/barrier island origin preserved in the geologic record may vary considerably from those seen at an instant in time in modern environments. The effects of large-scale facies architecture, especially aggradational or progradational architecture, may greatly enhance the vertical and dip-oriented lateral dimensions outlined above.

Jackson (1992) summarized dimensions of internal barrier island facies components (Table 2.4) from the work of 15 researchers. This work summarizes results for barrier islands deposited under mesotidal conditions (i.e., having moderate tidal energy with a tidal range of from 6 to 12 feet). Variation factors in Table 2.4 may be interpreted as a very rough measure of the predictability of the thickness, width, or length dimension in question. The thickness, length, and, to some extent, width of tidal inlet deposits appear to be difficult to anticipate, probably because of the tendency of inlets to migrate laterally with time.

\begin{tabular}{|c|c|c|c|c|c|c|}
\hline FACIES & $\begin{array}{c}\text { THICKNESS, } \\
\text { FT }\end{array}$ & $\begin{array}{l}\text { VARIATION } \\
\text { MAX/MMN }\end{array}$ & $\begin{array}{l}\text { WIDTH, } \\
\text { MILES }\end{array}$ & $\begin{array}{l}\text { VARIATION } \\
\text { MAXMMN }\end{array}$ & $\begin{array}{l}\text { LENGTH, } \\
\text { MIIIES }\end{array}$ & $\begin{array}{l}\text { VARIATION } \\
\text { MAX/MIN }\end{array}$ \\
\hline BEACHRMGE & $12-90$ & 7.5 & $0.6-4.0$ & 6.7 & $2.0-12.0$ & 6.0 \\
\hline $\begin{array}{l}\text { WASHOVER } \\
\text { FAN/WASHOVERIOBE }\end{array}$ & $0.5-6.0$ & 12.0 & $0.4-1.6$ & 4.0 & $.8-1.8$ & 2.3 \\
\hline TIDALINLET & $5.0-100.0+$ & $20.0+$ & $0.1-1.0+$ & $10+$ & $0.6-4.0+$ & $6.7+$ \\
\hline FLOODTIDAL DEITA & $6.0-30.0$ & 5.0 & $0.3-4.0$ & 13.3 & $1.0-3.0$ & 3.0 \\
\hline EBB TIDAL DELTA & $15.0-75.0$ & 5.0 & $1.0-10.0$ & 10.0 & $1.5-6.0$ & 4.0 \\
\hline
\end{tabular}


A summary of 318 strandplain/barrier island reservoirs in the TORIS database indicates the majority (or mode) for these reservoirs is less than 2,000 acres in size with 20 feet of net pay (Jackson, 1992).

\subsubsection{Importance of Sequence Stratigraphic Considerations}

Sequence stratigraphy is the study of genetically related facies within a framework of chronostratigraphically significant surfaces (Van Wagoner et al., 1990). In practical terms, this means that, in the process of studying lateral and vertical facies relationships, rocks may be encountered that are physically adjacent to the facies of interest, but are separated from them by subtle surfaces (i.e., sequence boundaries) representing thousands to millions of years of geologic time. Rocks located on opposite sides of sequence boundaries are likely to be totally unrelated depositionally.

The large-scale stratigraphic framework of a play or reservoir should always be examined before undertaking detailed facies analysis. The rock record is very incomplete overall, and it is quite common for large time gaps to occur in sedimentary sections. Across the sometimes seemingly innocuous surfaces that represent these gaps, depositional conditions may vary drastically, the sediments above being in no way predictably related to those below. Walther's (1894) law concerning the vertical representation of facies that occur in lateral continuity with one another is useful and accurate, but it must be carefully applied.

The sedimentary record reflects an unending record of rises and falls in relative sea level, presenting countless opportunities for erosional surfaces to develop on previously deposited marine sediments, thus complicating their interpretations. Because sandstones are more resistant to later erosion than shales, sequence boundaries are often underlain by sandstones. Erosion often can emplace fluvial valleys (incised valleys) in underlying depositional sequences. These valleys may be filled at the beginning of the next transgressional sequence with rocks of higher or lower reservoir quality than the rocks below the erosional surface.

\subsubsection{Summary of Known Interwell-Scale Depositional Heterogeneities Affecting Fluid Flow}

Reservoirs producing from the distal bar facies may involve several relatively thin, moderatequality sands that may be of limited extent along depositional strike. These sands, whether they are wave-worked sands of the bar/barrier front or whether they are remnants of ebb tidal deltas, will be effectively separated vertically by finer-grained silts and shales of the bar/barrier front environment, but will tend to merge into more massively bedded, better reservoir-quality sands toward the bar/barrier crest.

Reservoirs producing from facies on the landward or lagoonward side of barrier island complexes may also involve thin, moderate-to-good-quality reservoir sands that are discontinuous along strike. These sands generally represent storm washover and/or flood-tidal delta deposits, and they too tend to merge toward the barrier crest into more massively bedded sands of the barrier core facies. 
Reservoirs producing from barrier island or strandplain deposits with well-developed eolian facies are likely to be affected by the fluid-flow baffling effects of scattered interdune swale facies deposits. These thin silty, clay-rich layers are effective barriers to vertical fluid transmissibility, but their lateral extent in both depositional dip and strike directions is limited (probably to a few 10 s to a few 100 s of feet).

Reservoirs producing from barrier core facies of any barrier island complex will nearly always be compartmentalized to some extent along strike by crosscutting tidal inlet facies. Tidal inlet facies may contain moderate-to-good reservoir quality rocks, but they represent deposition under a wide variety of energy conditions and shale drapes or shale plugs are commonly present as well. Tidal inlet barriers to lateral permeability are more numerous and more effective under circumstances where tidal energies are greater relative to wave energies.

\subsection{Overview of Major Class 4 Plays}

Chapters 3 through 6 of this report focus on the reservoir, production, and geological characteristics of the strandplain/barrier island plays in four areas of the country: Texas, Oklahoma, California, and the Rocky Mountains. Table 2.5 summarizes the TORIS oil-in-place volumes for these four regions. The plays in Texas and Oklahoma are the most significant of the Class 4 plays, representing about two thirds of the total original oil-in-place, cumulative production, ultimate recovery, and remaining oil-in-place. Figure 2.11 illustrates the significance of these regions in terms of the remaining oil-in-place, which is the target for future recovery projects. The plays in Texas and Oklahoma each total about $31 \%$ of this target. An additional $18 \%$ of the remaining oilin-place is in plays in California, and $11 \%$ is in plays in the Rocky Mountain states.

\begin{tabular}{|c|c|c|c|c|}
\hline \multicolumn{5}{|c|}{ 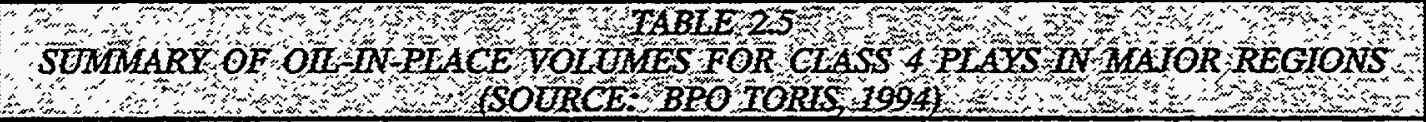 } \\
\hline REGIONS & $\begin{array}{l}\text { ORIGINAL } \\
\text { OIL-IN-PLACE } \\
\text { MMBO }\end{array}$ & $\begin{array}{l}\text { CUMULATIVE } \\
\text { RECOVERY } \\
\text { MMBO }\end{array}$ & $\begin{array}{l}\text { REMAINING } \\
\text { OIL-IN-PLACE } \\
\text { MMBO }\end{array}$ & $\begin{array}{l}\text { NUMBER } \\
\text { OF } \\
\text { RESERVOIRS }\end{array}$ \\
\hline TEXAS & 10,184 & 3,933 & 6,022 & 167 \\
\hline OKIAHOMA & 10,071 & 3,757 & 5,855 & 51 \\
\hline CALIFORNIA & 4,790 & 1,322 & 3,421 & 31 \\
\hline ROCKY MOUNTAIN & 3,131 & 998 & 2,106 & 58 \\
\hline OTHER & 2,579 & 858 & 1,693 & 23 \\
\hline TOTAL & 30,755 & 10,867 & 19,126 & 330 \\
\hline
\end{tabular}




\subsubsection{Reservoir Characteristics of Class 4 Plays}

The average reservoir parameters for the major Class 4 play groupings were calculated from TORIS data. Average values for net pay, porosity, initial oil saturation, depth, permeability, gravity, initial pressure, and ultimate recovery factor with existing operations are summarized in Table 2.6. Class 4 reservoirs in these plays range in depth from around 3,000 to 5,300 feet. Average net pay thickness ranges from 21 feet in the Texas plays to 132 feet in the California plays. California plays appear to have the best reservoir quality in terms of porosity (30\%) and permeability $(1,600$ $\mathrm{mD}$ ), but the oil gravity averages only $22^{\circ} \mathrm{API}$. Although pay thickness averages only 21 feet, reservoir quality of the Texas plays is good, with an average porosity of $27 \%$ and permeability of $849 \mathrm{mD}$, and the oil gravity is more favorable at $32^{\circ}$ API. Oklahoma plays seem to have poorer reservoir quality, with average porosity of $18 \%$ and average permeability of $292 \mathrm{mD}$, but average pay thickness is fairly high at 60 feet. Plays in the Rocky Mountain states exhibit the poorest reservoir quality based on these average TORIS parameters, with porosity averaging $17 \%$ and permeability around $170 \mathrm{mD}$.

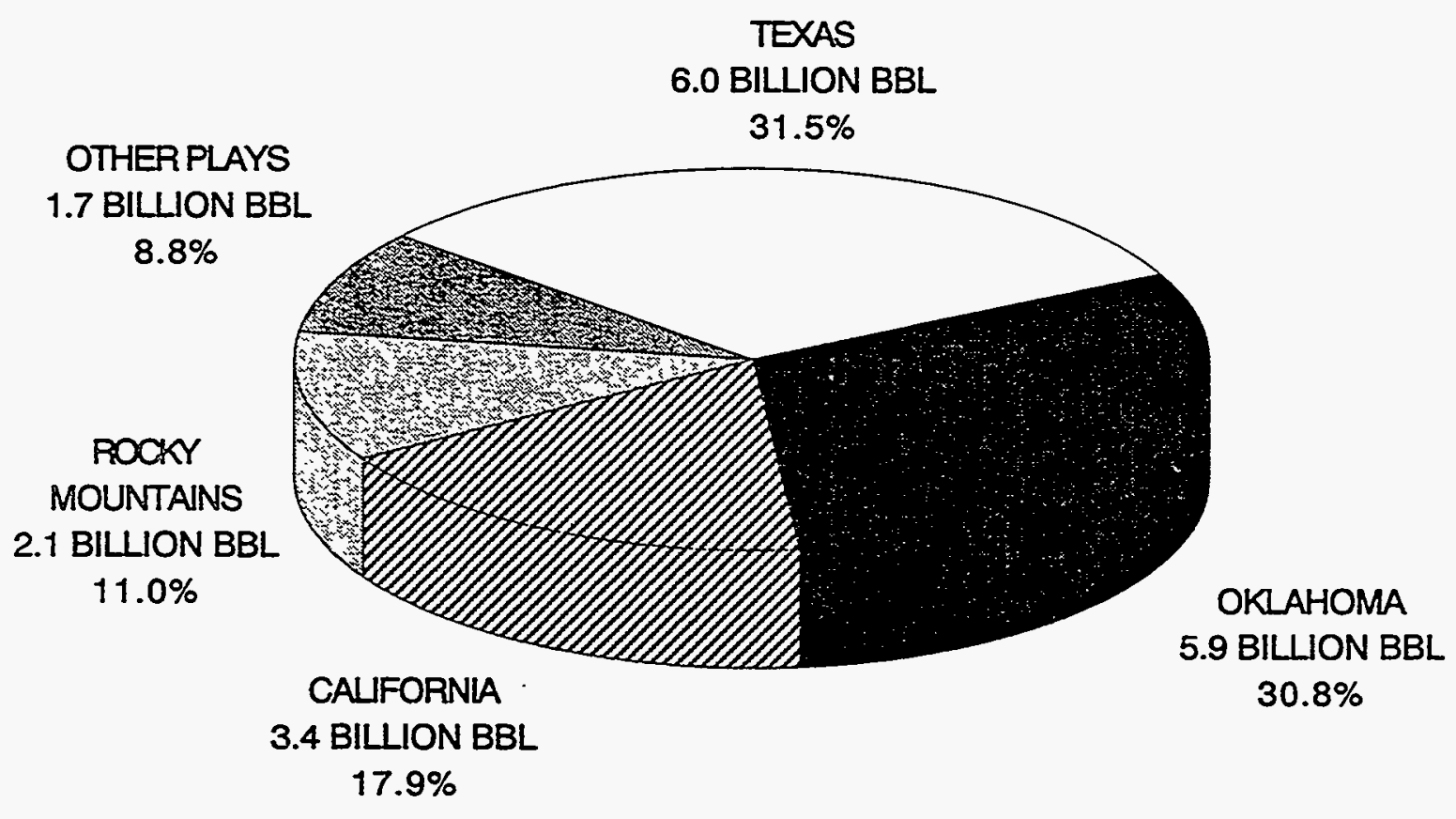

TOTAL ROIP $=19.1$ BILLION BBL

Figure 2.11 Remaining Oil-In-Place Distribution for Class 4 Plays in Major Regions (Source: BPO TORIS, 1994) 


\begin{tabular}{|c|c|c|c|c|c|c|c|c|}
\hline \multicolumn{9}{|c|}{ 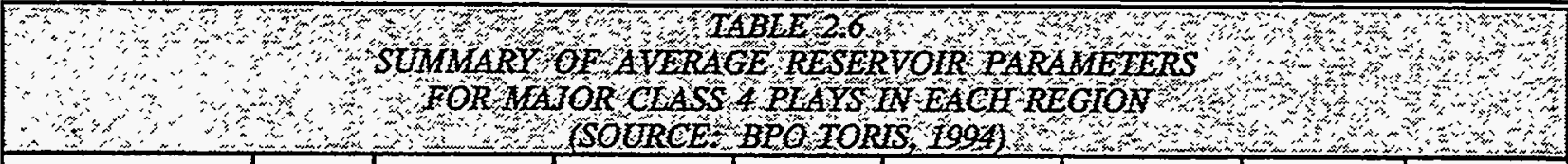 } \\
\hline MAJOR PLAYS & $\begin{array}{c}\text { NET } \\
\text { PAY, } \\
\text { FT } \\
\end{array}$ & $\begin{array}{c}\text { POROSITY, } \\
\% \\
\end{array}$ & $\begin{array}{c}\text { INIIIAL } \\
\text { OIL SATN., } \\
\%\end{array}$ & $\begin{array}{c}\text { DEPTH, } \\
\text { FT }\end{array}$ & $\begin{array}{c}\text { PERM- } \\
\text { EABIITY, } \\
\text { mD }\end{array}$ & $\begin{array}{c}\text { GRAVITY, } \\
\text { API }\end{array}$ & $\begin{array}{c}\text { INIIAL } \\
\text { PRESSURE, } \\
\text { PSI }\end{array}$ & $\begin{array}{c}\text { ULTMATE } \\
\text { RECOVERY, } \\
\%\end{array}$ \\
\hline TEXAS & 21 & 27 & 69 & 4,881 & 849 & 32 & 2080 & 43 \\
\hline OKLAHOMA & 60 & 18 & 69 & 4,431 & 292 & 36 & 1834 & 38 \\
\hline CALIFORNIA & 132 & 30 & 69 & 2,985 & 1637 & 22 & 1233 & 29 \\
\hline ROCKY MOUNTAINS & 27 & 17 & 69 & 5,317 & 169 & 37 & 2155 & 28 \\
\hline OTHER PLAYS & 22 & 22 & 70 & 4,559 & 511 & 34 & 1730 & 44 \\
\hline OVERALL AVERAGE & 52 & 23 & 69 & 4,434 & 692 & 32 & 1806 & 38 \\
\hline
\end{tabular}

\subsubsection{Production and Improved Recovery in Class 4 Plays}

Improved oil recovery activity and production levels in the Class 4 reservoirs listed in the TORIS database vary significantly by region. While some regions like Oklahoma and California have been significantly impacted by improved oil recovery, the region with the largest remaining oil-in-place volume, Texas, has been minimally impacted. The Rocky Mountain region has seen significant improved oil recovery activity, but the impact on overall production levels is not obvious. Details concerning improved oil recovery applications within the different regions are contained in Chapters 3 through 6 . The following summary level comments are applicable.

Production from Texas Class 4 reservoirs listed in the TORIS database exhibits the steepest natural decline of the major regions (Figure 2.12), indicating a great need for improved oil recovery applications. Although several improved oil recovery techniques have been applied, past and current production volumes from improved oil recovery projects have been and are minor when compared to overall production levels from Texas Class 4 reservoirs listed in the TORIS database. Techniques that have been applied include reservoir management, steam injection, in situ combustion, miscible gas injection, $\mathrm{CO}_{2}$ miscible injection, and polymer, alkaline polymer, and surfactant flooding.

Improved oil recovery applications have significantly impacted production levels from Oklahoma Class 4 reservoirs listed in the TORIS database. Several large polymer projects begun in the early 1980 s not only moderated production decline, but actually increased production levels. Recent applications of reservoir management and infill drilling indicate further potential exists. Although applicable to a limited area in Oklahoma, thermal improved oil recovery processes have historically had only minor impact in Oklahoma Class 4 reservoirs.

As expected, considering the concentration of heavy oil in California, steam projects play a major role in production from California Class 4 reservoirs listed in the TORIS database. About 22,000 BOPD (Moritis, 1992), or nearly all of the regional production from Class 4 reservoirs listed in the TORIS database, comes from large steam projects in the Mount Poso, Placerita, and San Ardo fields. 


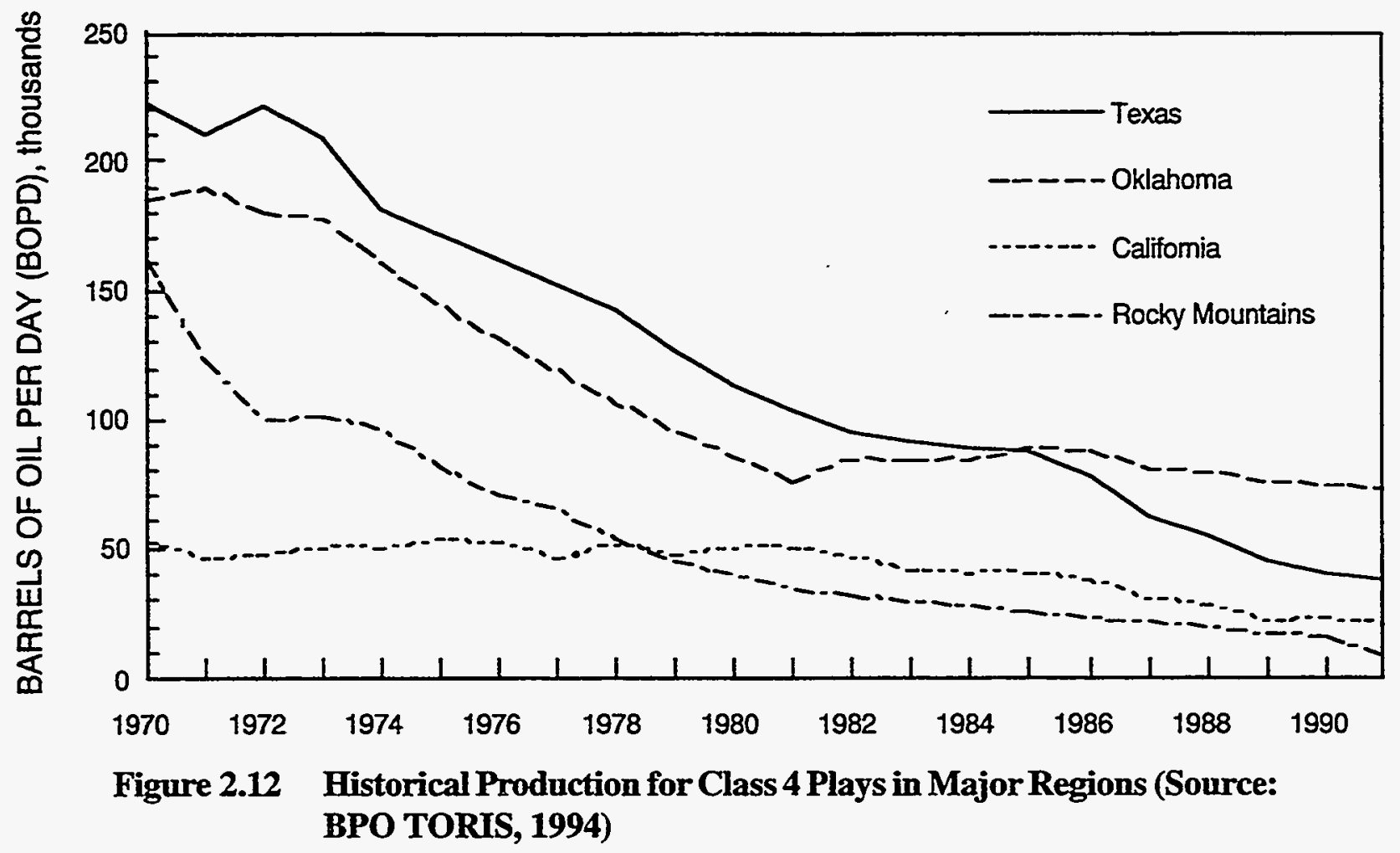

In Wyoming and the Rocky Mountain region, several improved oil recovery processes impact production. Polymers and gel polymers for either near-wellbore or in-depth conformance control are widely applied in the Rocky Mountain region. Although associated production volumes are as yet small, cyclical $\mathrm{CO}_{2}$ stimulation treatments are receiving considerable attention in Wyoming. Reservoir management techniques have demonstrated value in Rocky Mountain reservoirs. Improved oil recovery applications need to play an increasing role in the Rocky Mountain region to offset the recent production declines illustrated in Figure 2.12.

\subsection{References}

Beall, A.O., Jr., 1968, Sedimentary processes operative along the western Louisiana shoreline: Journal of Sedimentary Petrology, vol. 38, No. 3, p. 869-877.

Beck, R.J. and J.B. Biggs, 1992, OGJ 300: Smaller list, bigger financial totals: Oil and Gas Journal 1992 Databook, p. 1-21.

Bernard, H.A., C.F. Major, Jr., B.S. Parrott and R.J. LeBlanc, Sr., 1978, Recent sediments of southeast Texas: a field guide to the Brazos alluvial and deltaic plains and the Galveston barrier island complex: The University of Texas at Austin, Bureau of Economic Geology Guidebook No. $11,71 \mathrm{p}$.

Coleman, J.M., 1976, Deltas: processes of deposition and models for exploration: Continuing Education Publication Co., Inc., Champaign, Illinois, 102 p. 
Curray, J.R., F.J. Emmel, and P.J.S. Cranpton, 1969, Holocene history of a strandplain lagoonal coast, Nayarit, Mexico, in A.A. Castanores and F.B. Phleger, eds., Coastal lagoons: a symposium: Universidad Nacional Autonama de Mexico, p. 63-100.

Fisk, H.N., 1955, Sand facies of recent Mississippi delta deposits: Proceedings of the 4th World Petroleum Congress, Section 1/C, p. 377-398.

Friedman, G.M. and J.E. Sanders, 1978, Principles of sedimentology: John Wiley and Sons, 792 p.

Galloway, W.E., 1986, Reservoir facies architecture of microtidal barrier systems: American Association of Petroleum Geologists Bulletin, vol. 70, No. 7, p. 787-808.

Gary, M., R. McAfee, Jr., and C.L. Wolf, eds., 1974, Glossary of geology, American Geological Institute, $857 \mathrm{p}$.

Jackson, S.R., 1992, Summary of reservoir characteristics of shoreline barrier reservoirs: Department of Energy Report NIPER-651, November, 24 p.

McGowen, J.H., L.E. Garner, and B.H. Wilkinson, 1977, The Gulf shoreline of Texas: Processes, characteristics, and factors in use: The University of Texas at Austin, Bureau of Economic Geology Geological Circular No. 77-3, 27 p.

Moslow, T.F., 1984, Depositional models of shelf and shoreline sandstones: American Association of Petroleum Geologists Continuing Education Course Note Series No. 27, 102 p.

Moslow, T.F., and R.S. Tye, 1985, Recognition and characterization of Holocene tidal inlet sequences: Marine Geology, vol. 63, No. 1-4, p. 129-151.

Otvos, E.G., Jr. and W.A. Price, 1979, Problems of chenier genesis and terminology-an overview: Marine Geology, vol. 31, p. 251-263.

Penland, S., J.R. Sutter, and R. Boyd, 1985, Barrier island arcs along abandoned Mississippi River deltas: Marine Geology, vol. 63, p. 197-233.

Psuty, N.P., 1967, The geomorphology of beach ridges in Tabasco, Mexico: Louisiana State University, Coastal Studies Series No. 18, 51 p.

Reinson, G.E., 1979, Barrier island systems, in R. G. Walker ,ed., Facies Models, Geologic Association Canada, Reprint Series 1, p. 57-74.

Tyler, N. and W.A. Ambrose, 1986, Facies architecture and production characteristics of strandplain reservoirs in North Markham-North Bay City field, Frio formation, Texas: American Association of Petroleum Geologists Bulletin, vol. 70, No. 7, p. 809-829.

Van Wagoner, J.C., R.M. Mitchum, K.M. Campion, and V.O. Rahmanian, 1990, Siliciclastic sequence stratigraphy in well logs, cores, and outcrops: American Association of Petroleum Geologists, Methods in Exploration Series No. 7, 55 p.

Walther, J., 1894, Einleitung in die Geologie als historiche Wissenschaft: Jena, Verlag Von Gustav Fisher, 3 vols., p. 987-993. 


\section{CHAPTER 3 MAJOR TEXAS STRANDPLAIN/BARRIER ISLAND PLAYS}

The strandplain/barrier island reservoirs in Texas represent a significant portion of the Class 4 resource in the country, as defined in the DOE Tertiary Oil Recovery Information System (TORIS). Most of the Class 4 resource in Texas is found in three significant plays: the Frio Strandplain and Jackson Barrier/Strandplain Plays along the south-central Texas Gulf Coast, and the Cretaceous Salt-Related Play in the East Texas Basin. This chapter describes the geologic characteristics of these three plays and includes discussions of the unique geological context that leads to hydrocarbon trapping within each play.

The reservoir and production characteristics of the Texas Class 4 plays are summarized in this chapter based on the analysis of over 150 reservoirs contained in the TORIS database and review of the technical literature. This analysis indicates that reservoirs in these plays exhibit good reservoir quality and recovery, but production has not been significantly impacted by the application of improved recovery processes, other than waterflooding. Based on the literature review, the improved recovery processes which have shown favorable results in the Texas Class 4 plays include: infill drilling and $\mathrm{CO}_{2}$ injection in the Frio Strandplain Play; polymer, surfactant, gas injection and thermal in the Jackson Barrier/Strandplain Play; and polymer flooding, alkaline flooding, in situ combustion, steam injection and $\mathrm{CO}_{2}$ injection in the Cretaceous Salt-Related Play. If technological challenges can be overcome, significant potential exists for the application of improved recovery technologies in Texas Class 4 reservoirs (See Chapters 7 and 8).

\subsection{Overview of Texas Plays}

The Class 4 strandplain/barrier island sandstone reservoirs in Texas have been estimated by the Bureau of Economic Geology (BEG) to account for 5.5 billion barrels of oil or $12 \%$ of the original oil-in-place (OOIP) in clastic reservoirs in Texas (Tyler et al., 1984). Texas is a major contributor to oil production from Class 4 reservoirs listed in the TORIS database. Texas contains more than 6 billion barrels of remaining oil-in-place (ROIP) in Class 4 reservoirs listed in the TORIS database. This volume represents over $30 \%$ of the ROIP for Class 4 reservoirs listed in the TORIS database (Table 3.1). Cumulative recovery is $39 \%$ of the OOIP. Estimated remaining reserves with current operations are only 229 million barrels (versus cumulative production of 3.9 billion barrels) reflecting the maturity of the production.

Approximately $90 \%$ of the ROIP in Texas Class 4 reservoirs listed in the TORIS database is contained in three plays: the Frio Strandplain, the Jackson Barrier/Strandplain, and the Cretaceous Salt-Related Plays. A stratigraphic column relating comparative production volume importance of Texas Class 4 and other plays is shown in Figure 3.1.. All three major Class 4 plays contain both barrier island and strandplain deposits, but the geological context that leads to hydrocarbon trapping is unique to each play. The Frio strandplain/barrier island sands were deposited in an interdeltaic situation with little local sediment supply. Growth faulting associated with delta development resulted in aggradational or progradational architectures (Figure 2.10) and provided the trapping mechanism for many Frio strandplain/barrier island reservoirs. Jackson strandplain/barrier island deposits are best-developed in an embayment area well removed from major deltaic deposits. In 


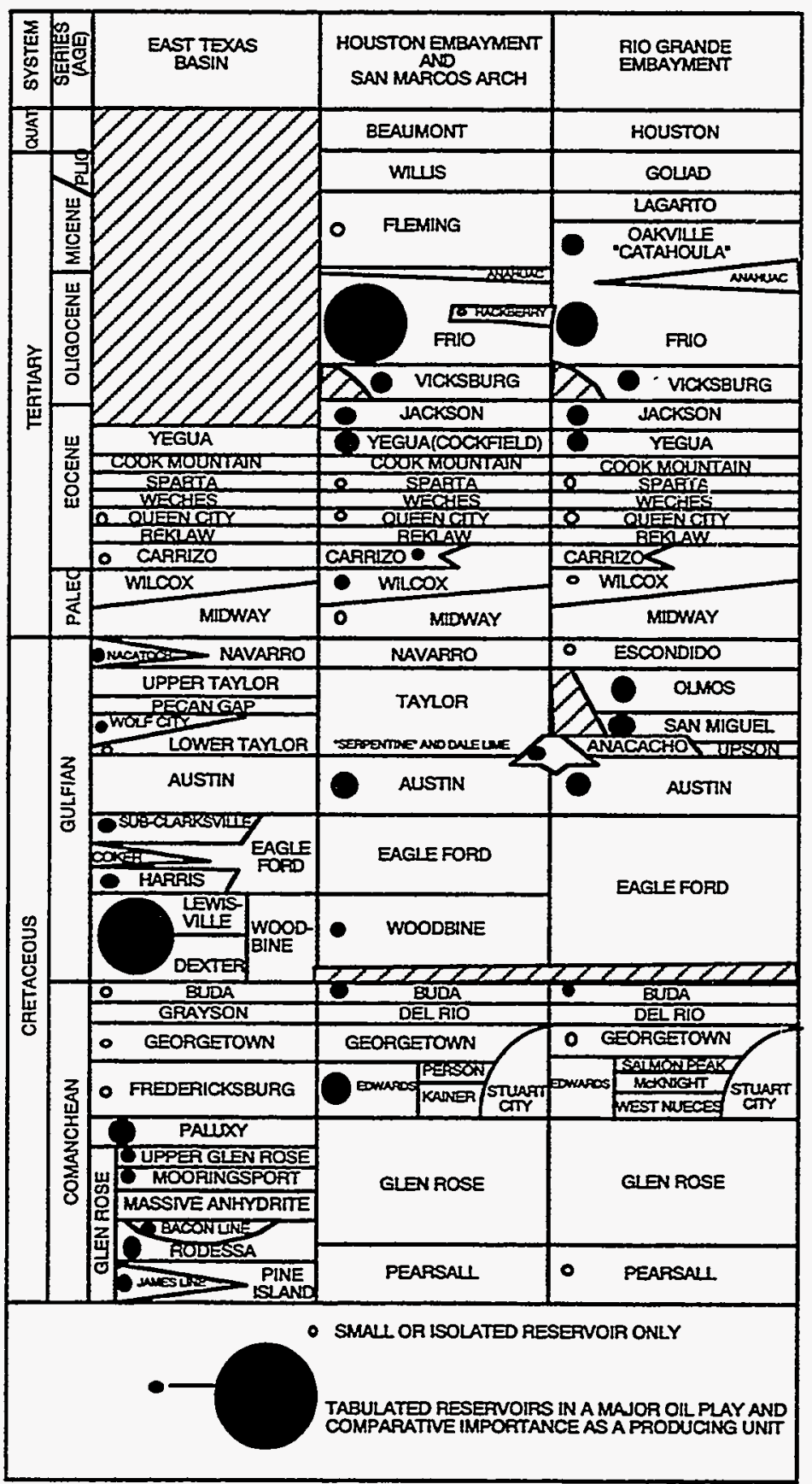

Figure 3.1 Stratigraphic Column for Texas Class 4 Plays (Modified from: Galloway et al., 1983) 


\begin{tabular}{|c|c|c|c|c|}
\hline \multicolumn{5}{|c|}{ 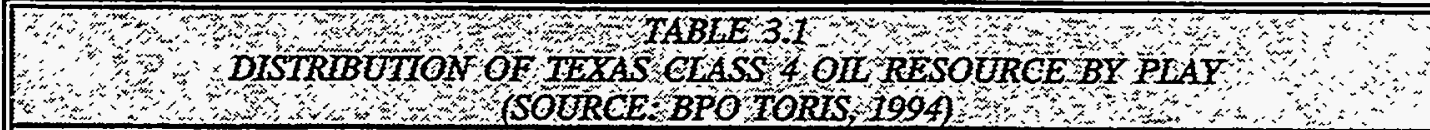 } \\
\hline PLAY & $\begin{array}{l}\text { ORIGINAI } \\
\text { OIL-IN-PLACE } \\
\text { MMBO }\end{array}$ & $\begin{array}{l}\text { CUMULATTVE } \\
\text { RECOVERY } \\
\text { MIMBO }\end{array}$ & $\begin{array}{l}\text { REMAINING } \\
\text { OIL-IN-PLACE } \\
\text { MMBO }\end{array}$ & $\begin{array}{l}\text { NUMBER } \\
\text { OF } \\
\text { RESERVOIRS }\end{array}$ \\
\hline FRIO STRANDPLAIN & 6,273 & 2,499 & 3,637 & 88 \\
\hline $\begin{array}{l}\text { JACKSON } \\
\text { BARRIER/STRANDPLAIN }\end{array}$ & 1,848 & 596 & 1,249 & $\overline{41}$ \\
\hline CRETACEOUS, SALT-RELATED & 957 & 360 & 519 & 20 \\
\hline $\begin{array}{l}\text { SUBTOTAL LARGEST } \\
\text { PLAYS }\end{array}$ & 9,078 & 3,455 & 5,404 & 149 \\
\hline WOODBINE FAULT LINE & 638 & 315 & 323 & 7 \\
\hline \begin{tabular}{|l} 
FRIO (BUNA) \\
BARRIER/STRANDPLAIN \\
\end{tabular} & 278 & 84 & 186 & 5 \\
\hline MISCELLANEOUS & 190 & 80 & 109 & 6 \\
\hline $\begin{array}{l}\text { SUBTOTAL OTHER TEXAS } \\
\text { PLAYS }\end{array}$ & 1,106 & 478 & 618 & 18 \\
\hline TOTAL TEXAS PLAYS & 10,184 & 3,933 & 6,022 & 167 \\
\hline
\end{tabular}

this embayment, local sources of sand augmented longshore currents in developing good barrier island and strandplain reservoirs in which hydrocarbons are trapped in the shallow subsurface in stratigraphic sand pinch-outs on the landward (updip) side of the deposits. In the East Texas Salt Basin, barrier island deposits in the Paluxy formation produce from structural traps caused by movement of the underlying salt. Paluxy strandplain deposits occur west of the Salt Basin, but production in these deposits is limited. A small amount of oil from the Cretaceous Woodbine formation comes from strandplain/barrier island deposits, some of which are associated with saltrelated structures.

The ROIP volumes and other average reservoir parameters for the three major plays and all other Texas plays are presented in Table 3.2. The Texas Class 4 production is primarily light oil with an average oil gravity of $32^{\circ} \mathrm{API}$ from moderate depths. The average net pay, porosity, and initial oil saturation for the Texas plays are 21 feet, 27\%, and 69\% respectively. The average reservoir permeability is approximately $850 \mathrm{mD}$. Estimated ultimate recovery efficiencies with current operations range from a high of $45 \%$ of the OOIP in the Frio Strandplain Play to a low of $34 \%$ of the OOIP in the Jackson Barrier/Strandplain Play.

Annual production volumes since 1970 for the three major Class 4 plays are illustrated in Figure 3.2. The production curves indicate a steady decline in the productivity of these reservoirs. Independents produce a significant percentage of the oil from Texas Class 4 reservoirs listed in the TORIS database. Figure 3.3, which is based on 1991 production data, indicates that $49 \%$ of the 1991 production volume was produced by small independents, followed with $39 \%$ by majors, $8 \%$ by large independents, and $4 \%$ by midsize independents.

Historical improved oil recovery activity in Texas Class 4 reservoirs is summarized in Table 3.3. The Jackson Barrier/Strandplain and Cretaceous Salt-Related Plays have seen the most activity with 11 and 9 projects respectively. Polymer and thermal processes have been the major processes in the Jackson Barrier/Strandplain Play. Although other processes have been employed, two-thirds of the projects in the Cretaceous Salt Related Play have been thermal. 


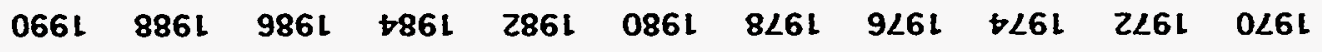

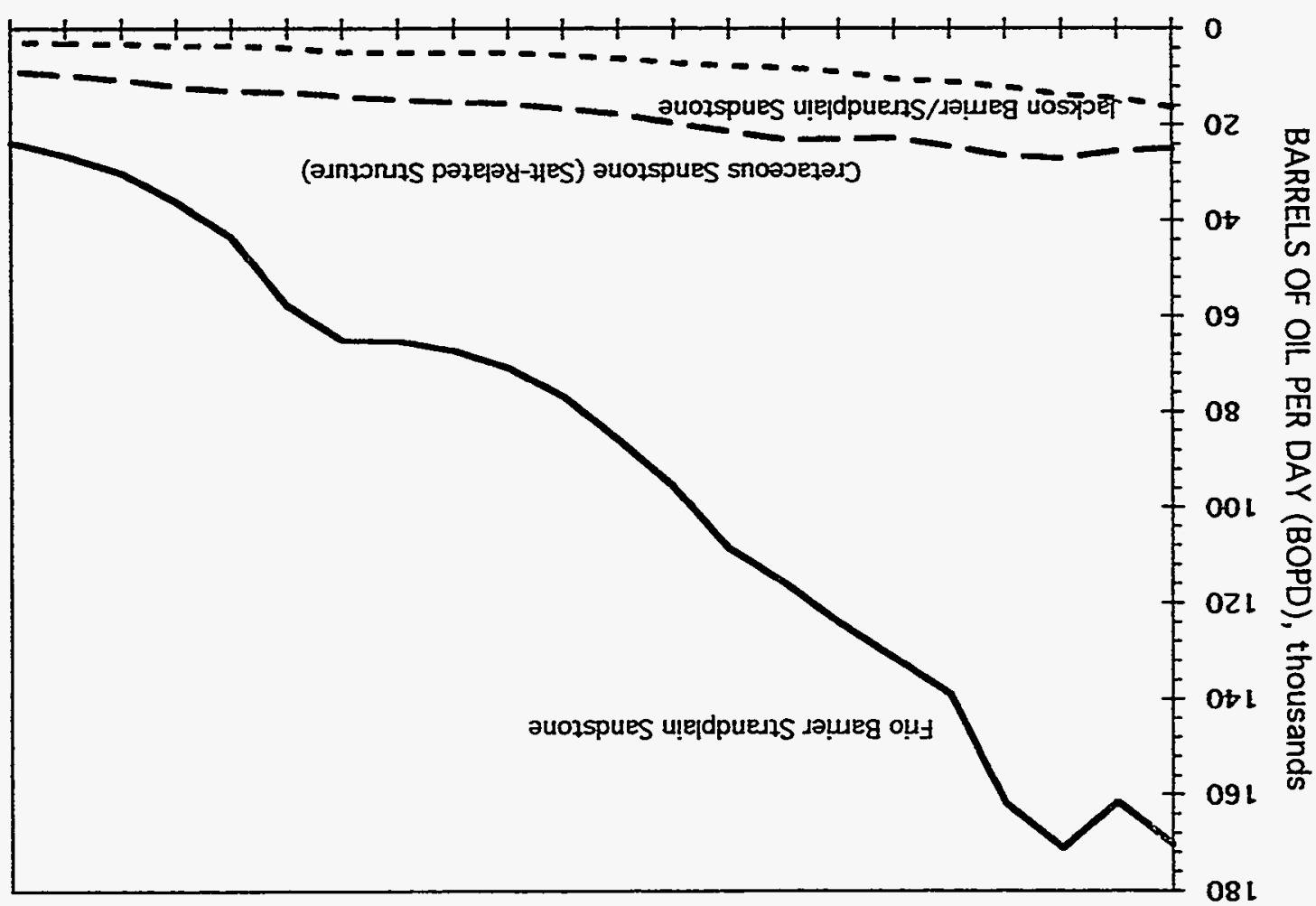

\begin{tabular}{|c|c|c|c|c|c|}
\hline$\overline{\varepsilon t}$ & $6 t$ & $\overline{\varepsilon t}$ & $\overline{\overline{t \varepsilon}}$ & $\overline{S b}$ & 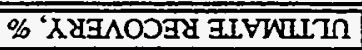 \\
\hline 0802 & $0+0 \%$ & ILt? & $\operatorname{LII} \mathfrak{I}$ & $\overline{\text { ISLC }}$ & ISd 'BynSSGyd TVLUIN] \\
\hline$\overline{\tau \varepsilon}$ & $\overline{\varepsilon \varepsilon}$ & $\overline{z \varepsilon}$ & $\overline{62}$ & $\overline{S E}$ & IdV .'XIIINVAD \\
\hline $6+8$ & $\varepsilon 00^{\circ} \mathrm{I}$ & $\overline{I L S}$ & $\overline{Z 59}$ & $\overline{L L I^{6} \mathrm{I}}$ & 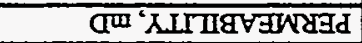 \\
\hline L88 & $5 \varepsilon \sigma^{\circ} t$ & $\overline{Z L L^{\prime} S}$ & $60 L^{2} 2$ & $0 \angle I^{4} 9$ & IA HUdGa \\
\hline 69 & 89 & $\varepsilon L$. & $\$ 9$ & $0 L$ & $\begin{array}{l}\text { \% NOIJVRNLVS } \\
\text { IIO TVIINI }\end{array}$ \\
\hline$\overline{L Z}$ & $\overline{62}$ & $\overline{z z}$ & $\overline{0 \varepsilon}$ & 62 & $\%$ 'XISOYOd \\
\hline$\overline{I Z}$ & $\overline{t z}$ & $\bar{\Omega}$ & $9 \mathrm{I}$ & $0 z$ & Id XVd IJN \\
\hline & $8 \mathrm{~s} 9$ & $6 \mathrm{TS}$ & $6 t \tau^{t} I$ & $L \varepsilon 9^{`} \varepsilon$ & $\begin{array}{r}\text { OgWW TSFId } \\
\text {-NI-TO ONINIVWII }\end{array}$ \\
\hline 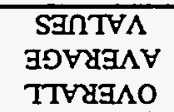 & SQIHLLO & 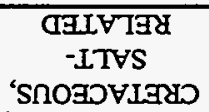 & 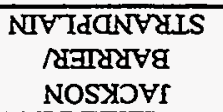 & $\begin{array}{l}\text { NIFTdaNFAIS } \\
\text { ORA }\end{array}$ & 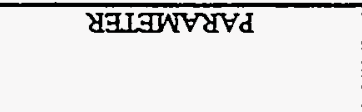 \\
\hline \multicolumn{6}{|c|}{ SxVId yorVW } \\
\hline & & 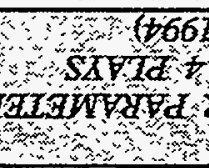 & 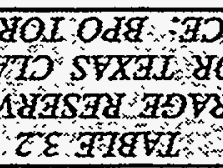 & 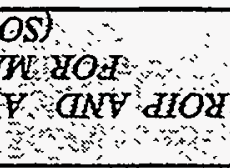 & 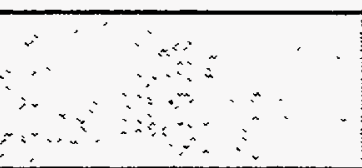 \\
\hline
\end{tabular}




\begin{tabular}{|c|c|c|c|c|c|c|c|c|}
\hline$\overline{\overline{62}}$ & $\overline{\overline{6}}$ & $\bar{L}$ & $\overline{9}$ & $\bar{z}$ & $\overline{\overline{\boldsymbol{S}}}$ & $\overline{\overline{6 I}}$ & $220^{\circ} 9$ & †SSFTSSVXII TVIOI \\
\hline $\bar{\varepsilon}$ & & & $\bar{\tau}$ & & $\bar{I}$ & $\overline{2}$ & 8 8โ9 & \&बHIO \\
\hline 6 & I & $\bar{\varepsilon}$ & $\bar{\varepsilon}$ & $\bar{I}$ & $\bar{I}$ & $\bar{S}$ & $\overline{6 I S}$ & 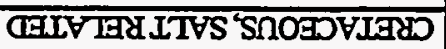 \\
\hline II & $\tau$ & $b$ & I & I & $\varepsilon$ & 6 & $6 t \tau^{6} I$ & 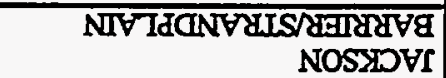 \\
\hline 9 & 9 & & & & & $\bar{\varepsilon}$ & $\angle \varepsilon 9^{4} \varepsilon$ & NFIdaNVAIS OIYI \\
\hline THIOL & SWD & HWHIS & $\begin{array}{l}\text { gNOJ } \\
\text { AIIS NI }\end{array}$ & TVDINEHD & ४हाNXTOd & $\begin{array}{c}\text { SQTIIH } \\
\text { JO } \\
\text { ON }\end{array}$ & $\begin{array}{l}\text { OgWW } \\
\text { 'dơ } \\
\text { ST\&OL }\end{array}$ & \multirow[t]{2}{*}{ XVId } \\
\hline \multicolumn{8}{|c|}{ SIDEROYd $10^{\circ}$ ON } & \\
\hline
\end{tabular}

\section{(\$66I' 'SIROL

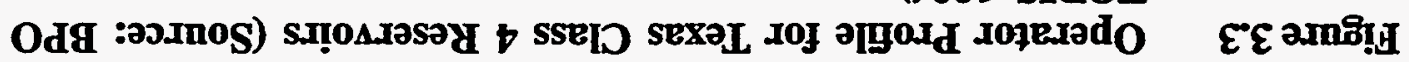

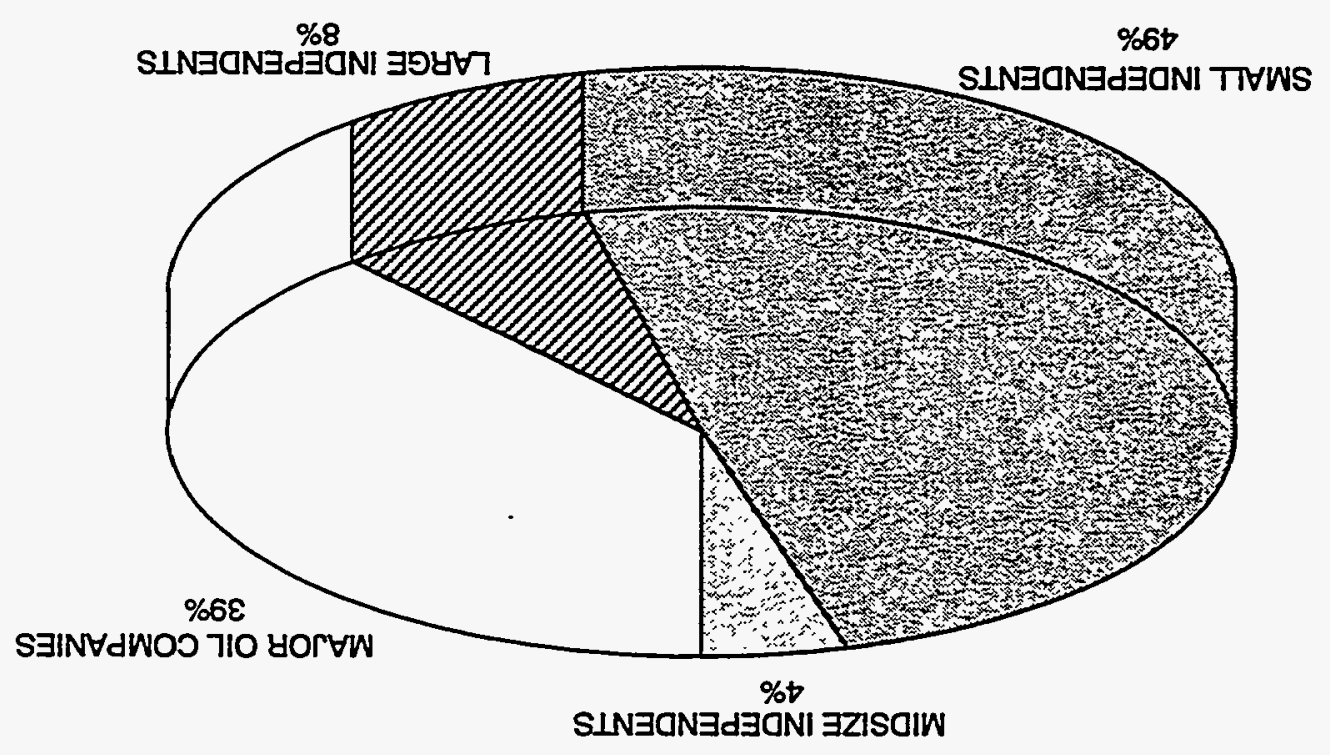




\subsection{Frio Strandplain/Barrier Island Play}

\subsubsection{Play Description}

Frio production in Texas comes from both fluvial-deltaic and strandplain/barrier island sands. The main area of Oligocene Frio Class 4 strandplain/barrier island oil production extends in a 160mile-long by 50-mile-wide trend along the south Texas Gulf Coast (Figure 3.4). South and west of this trend, the strandplain/barrier island Frio sands give way to units deposited in the Rio Grande Embayment in a fluvial-deltaic Frio environment (Figures 3.5 and Figure 3.6).

Around Houston, the structural environment changes, with the presence of a second large embayment. Within this Houston Embayment, thick salt deposits accumulated during the Mesozoic Era, and a deltaic depositional environment prevailed during Frio deposition (Figures 3.5 and 3.6) (Galloway et al., 1983).

A second, small, localized Frio (Buna) Strandplain/Barrier Island Play is located northeast of the salt dome area, along the Louisiana border. The area of this development is limited, and the reserves here are much smaller than in the main Frio play to the southwest (Figure 3.6) (Galloway et al., 1983).

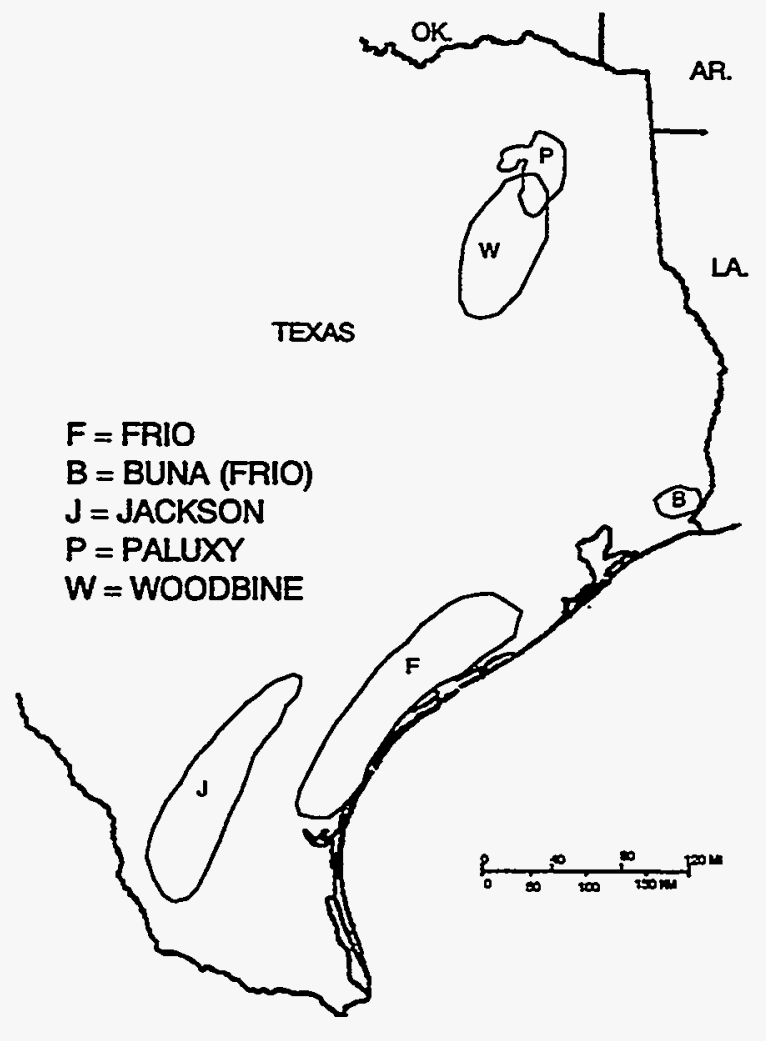

Figure 3.4 Location Map for Frio, Buna, Jackson, Paluxy, and Woodbine Class 4 Plays in Texas (Modified from: Tyler et al., 1984) 


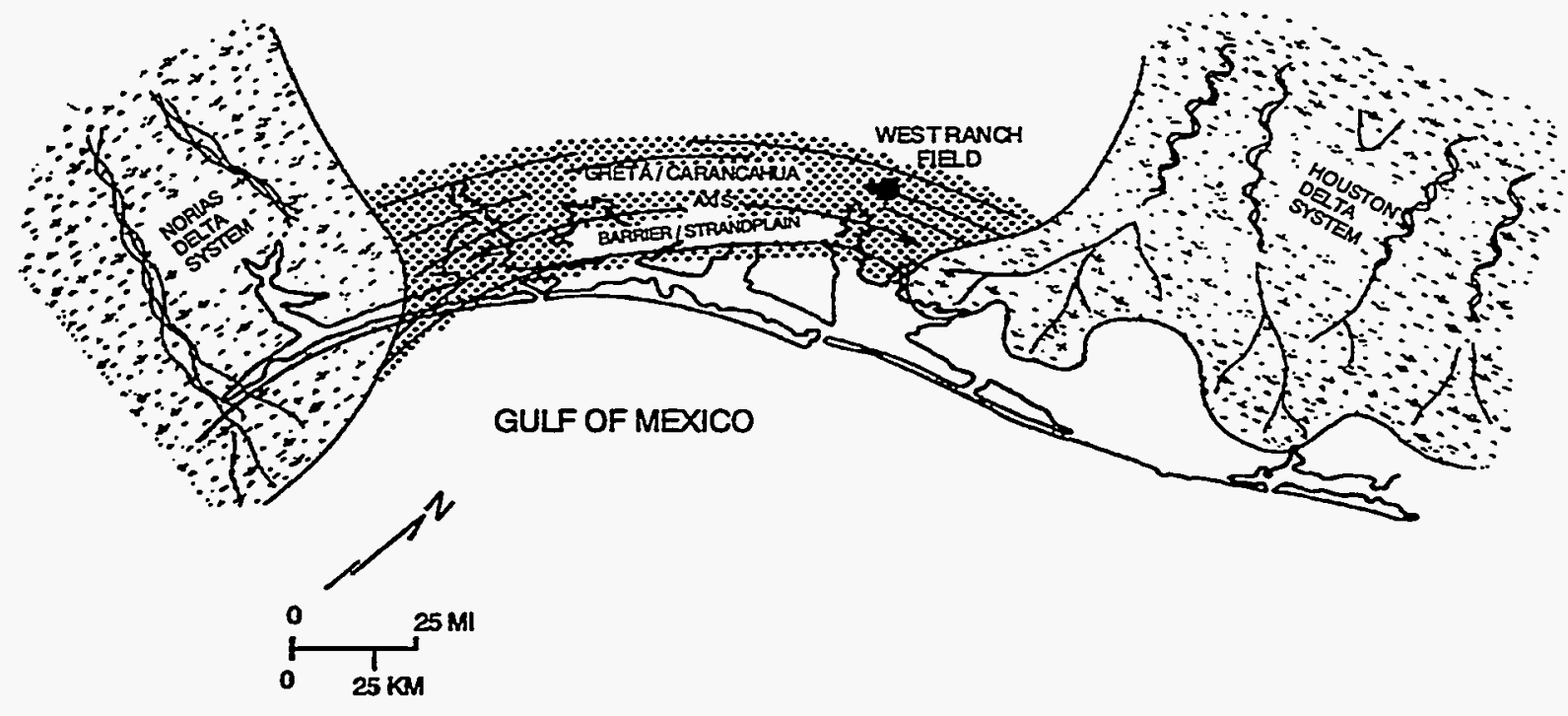

Figure 3.5 Paleoenvironments Associated with Deposition of Texas Class 4 Reservoirs in the Frio Play (Source: Galloway and Cheng, 1985, p. 7)

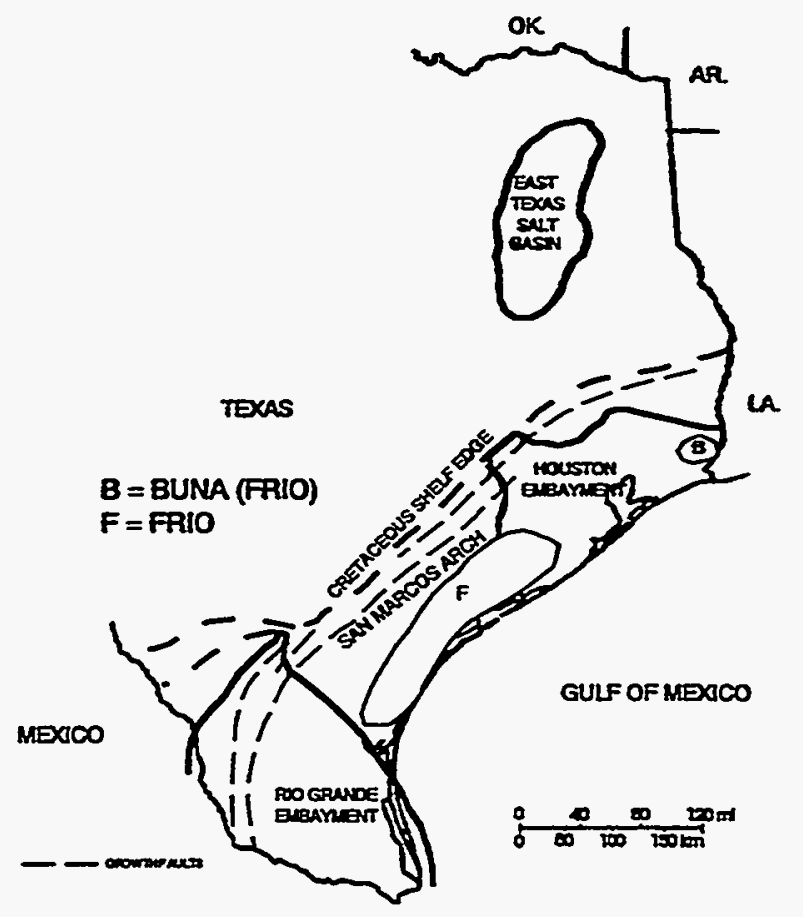

Figure 3.6 Structural Features Affecting Deposition of Texas Class 4 Reservoirs in the Frio Play (Modified from: Tyler et al., 1984; Galloway et al., 1983) 
The Frio standstones were formed as shoreline or strandplain deposits and offshore barrier islands in an interdeltaic area along the Oligocene coast of the Gulf of Mexico. Most of the sediments from inland Texas were dumped into the Rio Grande or Houston Embayments during the period of Frio deposition, and there was little local sediment influx to this interdeltaic coast. The Gulf of Mexico was a restricted body of water, with lower wave energies than an open ocean, and there was a low or micro-tidal range (less than 3 feet) along the coast where the Frio was being deposited (Galloway and Cheng, 1985).

Growth faulting along the margin of the Gulf of Mexico was very important in controlling the Frio depositional pattern. A series of active, down-to-the-Gulf, faults (Figure 3.5) had a strong influence on the shoreline position during the deposition of the Frio sands, both in the main trend and in the area along the Louisiana border (Galloway et al., 1983; ICF and BEG, 1990; Dutton and Garrett, 1985). The Vicksburg and Frio Fault Zones were both active as the Frio was being deposited in the main trend area. Minor, local faults are seen in the Frio-age strandplain/barrier island deposits along the Texas/Louisiana border.

The Vicksburg and Frio Fault Zones follow the San Marcos Arch. As the Houston Embayment sank rapidly to the northeast and the Rio Grande Embayment subsided to the southwest under a deltaic sediment load, the arch area remained relatively stable, sinking comparatively slowly (Galloway et al., 1983). Frio shorelines tended to remain in place above individual, deep-seated, faults for relatively long periods of time. This allowed thick aggradational sands to accumulate under good conditions for the formation of reservoir rock. In many cases, multiple Frio sands stacked, one above another, producing patterns where a single well could encounter numerous payzones within a short interval of Frio. Many of the barrier islands, through time, grew upward and shifted position seaward, forming broad, tabular sand bodies.

As movements occurred on the deep-seated faults over time, tabular reservoir-sand bodies were warped into small rollover anticlines, and/or broken by small shallow faults into separate pockets (Galloway et al., 1983). In these sediments, oil tends to be found in structural traps in the massive, relatively clean, well-developed, barrier-core sands, or in smaller stratigraphic traps in the thin, more-discontinuous, shoreface and fore-barrier sands and in updip back-barrier sands.

\subsubsection{Reservoir Characteristics, Models, and Major Controls on Production}

Individual Frio sand bodies tended to be deposited as linear sands, elongate bodies, parallel to the coastline. The sands are typically well sorted, with good to excellent potential recovery efficiencies. Individual barrier cores generally terminate abruptly along strike, where they have been cut off by tidal inlets. While these strandplain/barrier island reservoirs could be expected, in theory, to form a series of long, linear, strike-parallel, reservoirs, in actuality, the typical Frio sand morphology is much more complicated.

Once the Frio strandplain/barrier island complex formed, tectonic movement caused the depositional setting to gradually change. The Frio Coast slowly subsided and additional sediment reached the coast from local rivers and longshore currents, causing the beaches and barrier islands to build upward and shift seaward or landward. In most cases, the Frio sands advanced into the Gulf, i.e. they were generally progradational. During periods of low subsidence, the sands aggraded. During periods when 
the coast was not receiving sufficient sediment to balance the subsidence, barrier islands and strandlines were often destroyed by storms and day-to-day microtides.

The Frio Coast subsided at varying rates over time. Eustatic sea level did not remain constant. Tidal inlets shifted laterally with time, and occasional storms breached barrier islands. As a result, the barrier islands seldom built straight upward for any prolonged period of time. Barrier island deposits had a tendency to migrate laterally, seaward or shoreward, over time. In this way, many of the linear barrier-sand bodies evolved, into broad, widespread, tabular bodies. Most Frio sand field maps today show elongate productive areas, several well spacings wide.

Maps may show laterally continuous units, which could be expected to drain in uniform patterns, but tidal inlets frequently truncate sands at unlogged points, or form barriers that inhibit lateral fluid flow.

The internal structure of strandplain/barrier island sands is complex. Permeabilities in barrier core deposits are generally quite high, frequently exceeding 1 Darcy over broad areas, and they may be as high as several Darcies in the best reservoirs. Isopermeability contours follow the strike of the units. Barrier core sands tend to be relatively homogeneous, with internal structural trends and depositional discontinuities dipping seaward. The best Frio reservoirs occur in the massive barrier core sands (ICF and BEG, 1990). These units can form long trends, producing large pools; although a series of thinner, more irregular strandplain deposits can also form good-quality reservoirs. A number of isolated producing zones can often be found within seemingly continuous, uniform sands. In tidal inlets, the bedding is much more complex, with extensive crosscutting, scour structures, and cut and fill. Permeabilities can be high, but high-permeability zones tend to be local, generally concentrated at the base of an inlet fill. The best permeabilities within an inlet deposit seldom exceed 1 Darcy.

Back-barrier, lagoon and tidal delta deposits also complicate the depositional picture. These are all relatively low-energy settings, and in each case, traces of mud are common, either as impermeable layers or coatings, or as significant shale pockets. Clay and shale coatings or layers can create either minor bedding discontinuities with slightly decreased porosity and permeability, inhibiting the migration of oil, or they can create major barriers, isolating separate reservoirs within a single sand body. Some of these barriers can be difficult to detect if a well has not been drilled at exactly the right location. The low-energy, back-barrier deposits tend to be heterogeneous, highly unpredictable, and erratic, with a wide range of permeabilities.

In many areas, the Frio reservoirs are faulted and broken into smaller units. Single, large sand bodies may produce as several isolated reservoirs. Sophisticated logging techniques, analysis of production patterns and pressures, and more detailed fault mapping can help determine the limits of various producing units. 


\subsubsection{Production Characteristics}

The Frio Strandplain Play has the highest ROIP ( 3.6 billion barrels of oil) among all the Class 4 plays in Texas. The relative importance from a production standpoint of the Frio in comparison with other producing formations of Cretaceous and Tertiary age of the south Texas Coast is shown in Figure 3.1. Net pay averages 20 feet. Initial oil saturation averages $70 \%$ with an average oil gravity of $35^{\circ}$ API. Porosity is $29 \%$ with an average permeability of $1,171 \mathrm{mD}$, higher than other Texas plays. The thickness-weighted-average porosity for the Frio has been reported as $27 \%$ (Tyler et al., 1984). Weighted-average permeability along the main Frio trend is $795 \mathrm{mD}$ (Dutton and Garrett, 1985). In the northeastern area along the Louisiana border, the thickness-weighted-average porosity increases to $29 \%$, and the weighted-average permeability increases to $1,535 \mathrm{mD}$. Reservoir depth averages just over 6,000 feet.

Oil recovery in the Frio is generally quite high reflecting good reservoir quality and, in many cases, high recovery efficiencies from strong waterdrive reservoirs. The average recovery efficiency for the largest strandplain/barrier island reservoirs was 53\% (Tyler et al., 1984). Production-weighted recovery efficiencies in these plays was $50 \%$. These numbers may be exceptional, however. A separate study (Dutton and Garrett, 1985) of smaller, older, fields that had already been abandoned showed that the average recovery efficiency for those reservoirs had only been $43 \%$. At the Texas/Louisiana border area, the Buna Play had a 37\% average recovery efficiency (Dutton and Garrett, 1985), despite high porosities and permeabilities. Lower recoveries may reflect lower levels of attention and development. There was little indication of any advanced reservoir engineering or of many attempts at improved oil recovery operations in those fields.

The Frio Strandplain Play consists of 88 reservoirs. Of these, 44 are major reservoirs that have produced over 10 million barrels of crude oil as of 1981 (ICF and BEG, 1990). These reservoirs account for an estimated 4.2 billion barrels of OOIP or $67 \%$ of the total estimated OOIP in the play.

Water drive is the prevalent source of reservoir energy (ICF and BEG, 1990). On the eastern and western margins of the play, however, gas-cap or solution-gas drives can accompany or supersede the water drive (Galloway et al., 1983). Secondary recovery has been largely limited to pressure maintenance by water and gas injection.

More detailed mapping, with special attention to the identification of fault barriers, tidal inlets, and subtle permeability changes may lead to recovery of a considerable quantity of mobile oil in this play.

\subsubsection{Improved Oil Recovery Projects}

Texaco conducted $\mathrm{CO}_{2}$ miscible projects in the Magnet Withers, Pickett Ridge, and Withers North fields. Table 3.4 summarizes the reservoir characteristics by field for these projects. In the Magnet Withers field in Wharton County, Texaco conducted one- and 27-well projects. Peak production from the larger project was 576 barrels of oil per day (BOPD). Similar $\mathrm{CO}_{2}$ injection projects were conducted by Texaco in the early 1980 s in nearby Pickett Ridge and Withers North fields. Although the projects in all fields were technically successful and economically promising, they were not continued. Suspected reasons for the projects not being continued were lack of an available $\mathrm{CO}_{2}$ source combined with declining oil prices. 


\begin{tabular}{|c|c|c|c|c|c|c|}
\hline \multicolumn{7}{|c|}{ 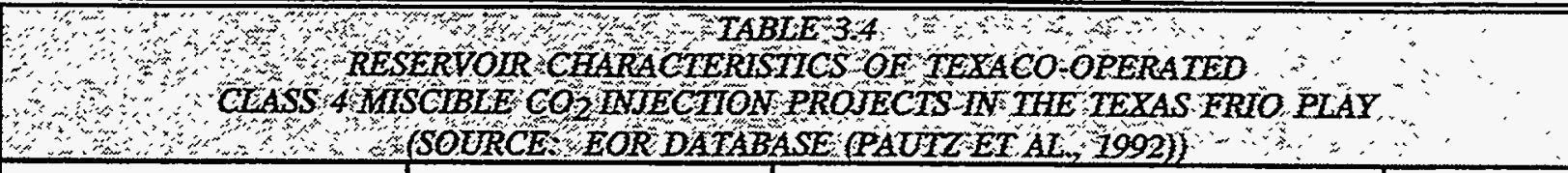 } \\
\hline \multirow[b]{2}{*}{ PARAMETER } & \multicolumn{2}{|c|}{ MAGNET WTTHERS } & \multicolumn{3}{|c|}{ WITHERS NORTH } & \multirow{2}{*}{$\begin{array}{l}\text { PICKETT } \\
\text { RIDGE }\end{array}$} \\
\hline & NO. 1 & NO. 2 & NO. 1 & NO. 2 & NO. 3 & \\
\hline START DATE & 1983 & 1984 & 1983 & 1983 & 1984 & 1983 \\
\hline SIZE, ACRES & 40 & 1,265 & 220 & 360 & - & 726 \\
\hline NO. WELLS & 1 & 27 & 3 & 5 & 10 & 6 \\
\hline DEPTH, FT & 5,500 & 5,400 & 5,250 & 5,360 & 5,100 & 4,600 \\
\hline POROSITY, \% & 23 & 23 & 26 & 25 & 25 & 30 \\
\hline PERMEABI ITY, mD & 1,700 & 1,700 & 1,050 & 400 & 1,000 & 1,200 \\
\hline GRAVITY, ${ }^{\circ} \mathrm{API}$ & 26 & 26 & 26 & 25 & 26 & 25 \\
\hline $\begin{array}{l}\text { PEAK PROJECT } \\
\text { PRODUCTION, B/D }\end{array}$ & 10 & 576 & 21 & 200 & 319 & 109 \\
\hline
\end{tabular}

Infill drilling offers significant potential for recovering the unrecovered mobile oil (UMO) resource from oil reservoirs in the Frio Strandplain Play. An infill drilling study conducted for the Department of Energy (ICF and BEG, 1990) contrasted reserve addition potential using three infill drilling scenarios: (1) play-wide blanket infill drilling, (2) selective reservoir-wide infill drilling, and (3) strategic or geologically targeted infill drilling.

Reserve addition potential from geologically targeted infill drilling considered the facies distributions in different reservoirs and facies continuity functions. Reservoir facies distributions were estimated from net sand maps, cross sections and type logs. Facies continuity functions were based on facies continuity observed in the 41-Areservoir in the West Ranch field, a major Frio strandplain/ barrier island reservoir. Figure 3.7 illustrates facies continuity functions for the predominant facies (barrier core, back-barrier [lagoonal facies of this report], and tidal inlet) and a combination or weighted function considering the relative volumes of the different facies. Facies with steeply declining curves require closer well spacing patterns to arrive at high pay-continuity values. The pay-continuity functions indicate that the back-barrier facies exhibits the greatest reservoir heterogeneity, the barrier core facies exhibits the least heterogeneity, with the tidal inlet facies heterogeneity intermediate between the two.

Reserves from infill drilling were calculated as a function of oil price for the three drilling scenarios. Play-wide incremental reserves are summarized in Table 3.5. In all cases, geologically targeted infill drilling recovers significantly more oil than blanket infill drilling. As oil price rises, incremental reserves from selective reservoir-wide drilling approach those recovered with strategic infill drilling. However, even though incremental reserves are nearly the same, costs per barrel with geologically targeted infill drilling are about one-half those experienced with selective reservoir-wide drilling. Regardless of oil price, costs per barrel are lower with geologically targeted infill drilling. 


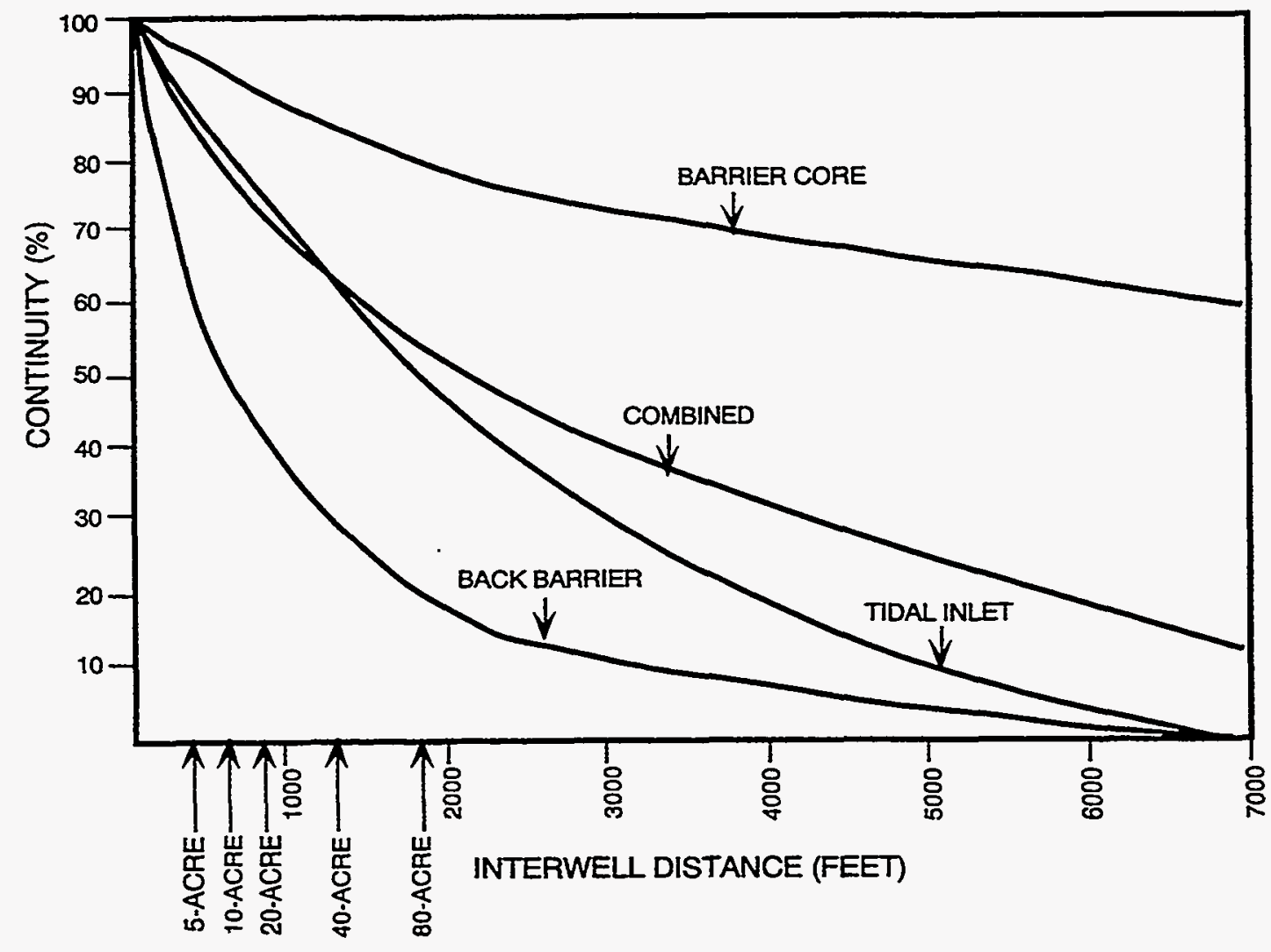

Figure 3.7 Pay Continuity Functions for Major Facies of the West Ranch Field 41-A Reservoir, a Class 4 Reservoir in the Texas Frio Play (Source: ICF and BEG, 1990)

\begin{tabular}{|c|c|c|c|c|c|c|}
\hline 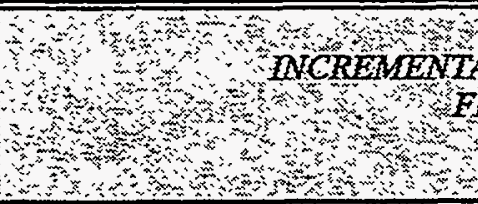 & 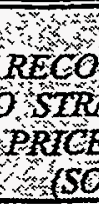 & 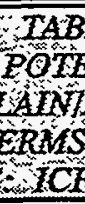 & 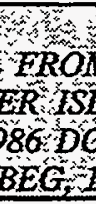 & $\bar{L}$ & $\frac{1}{2}$ & s. \\
\hline & & & & & & \\
\hline SCENARIO & $\mathrm{MMB}$ & $\mathrm{BCF}$ & MMB & $\mathrm{BCF}$ & MMB & $\mathrm{BCF}$ \\
\hline BLANKET PLAYWDE & 90 & 50 & 120 & 65 & 130 & 75 \\
\hline $\begin{array}{l}\text { SELECTIVE RESERVOIR- } \\
\text { WIDE }\end{array}$ & 115 & 60 & 190 & 100 & 240 & 125 \\
\hline GEOLOGICALLY-TARGETED & 150 & 80 & 215 & 110 & 245 & 130 \\
\hline
\end{tabular}




\subsection{Jackson Strandplain/Barrier Island Play}

\subsubsection{Play Description}

Various Jackson Group sediments were deposited along the Texas Gulf during Upper Eocene time from the Louisiana border to the Rio Grande. In East Texas, most of these sediments were fluvial or deltaic. A strandplain/barrier island system (Figure 3.4) was deposited along the South Texas portion of this trend inland from the Frio barrier deposits. The Jackson begins in Texas at the Rio Grande, and runs in a 35 to 50 mile wide band to the northeast.

The Jackson environment of deposition was quite similar to that which had prevailed in the region during Frio time (Figure 3.9). A large fluvial-deltaic system was building in the Houston Embayment, with the influx of large quantities of sand and mud. Southwest of this delta, the coast overlay the more stable San Marcos Arch, which was subsiding much more slowly than the

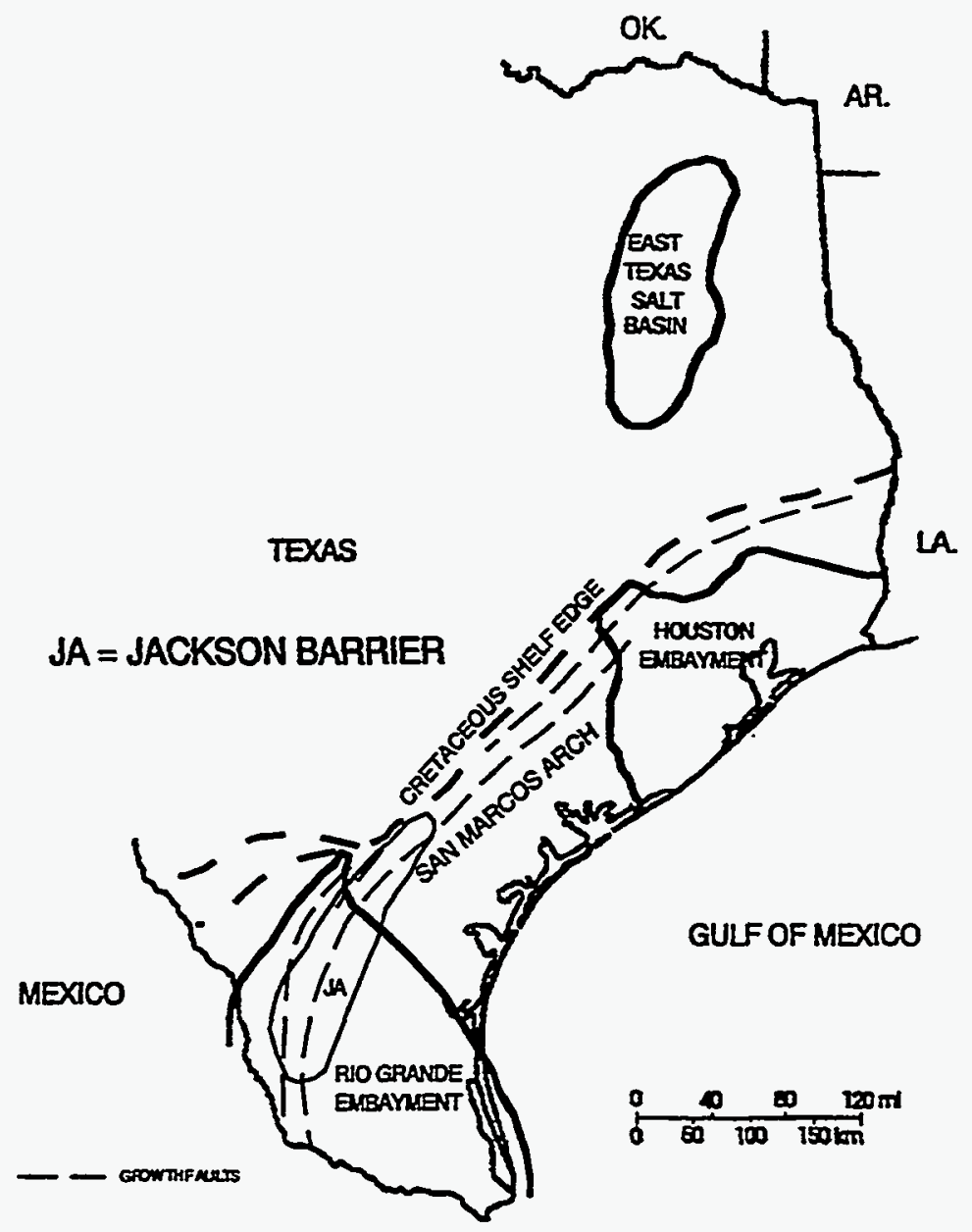

Figure 3.8 Structural Features Affecting Deposition of Texas Class 4 Reservoirs in the Jackson Play (Modified from: Tyler et al., 1984; Galloway et al., 1983) 
embayment area. During Jackson time, sediment supply, current conditions, and shoreline stability were not optimal for formation of reservoir-quality strandplain/barrier island deposits along the San Marcos Arch.

In the Rio Grande Embayment, conditions were more favorable. Additional local sediment supplies and subtle influences of the embayment tectonics, along with movement patterns on the Wilcox Faults, caused thicker, cleaner sands to accumulate producing better potential reservoirs (Fisher et al., 1970). Over time, the sand bodies developed into relatively wide tabular sands. The best reservoirs are found in barrier island deposits. In the northern portion of the Jackson trend, individual tabular sand bodies tend to climb section both to the land-side and to the north. Thus, recognizing north closure can become important in the northern sections of the Jackson trend (Fisher et al., 1970).

As the coast in the Rio Grande Embayment region slowly sank, growth-fault movement on the Wilcox System caused the beach fronts and barrier island locations to stabilize for long periods of

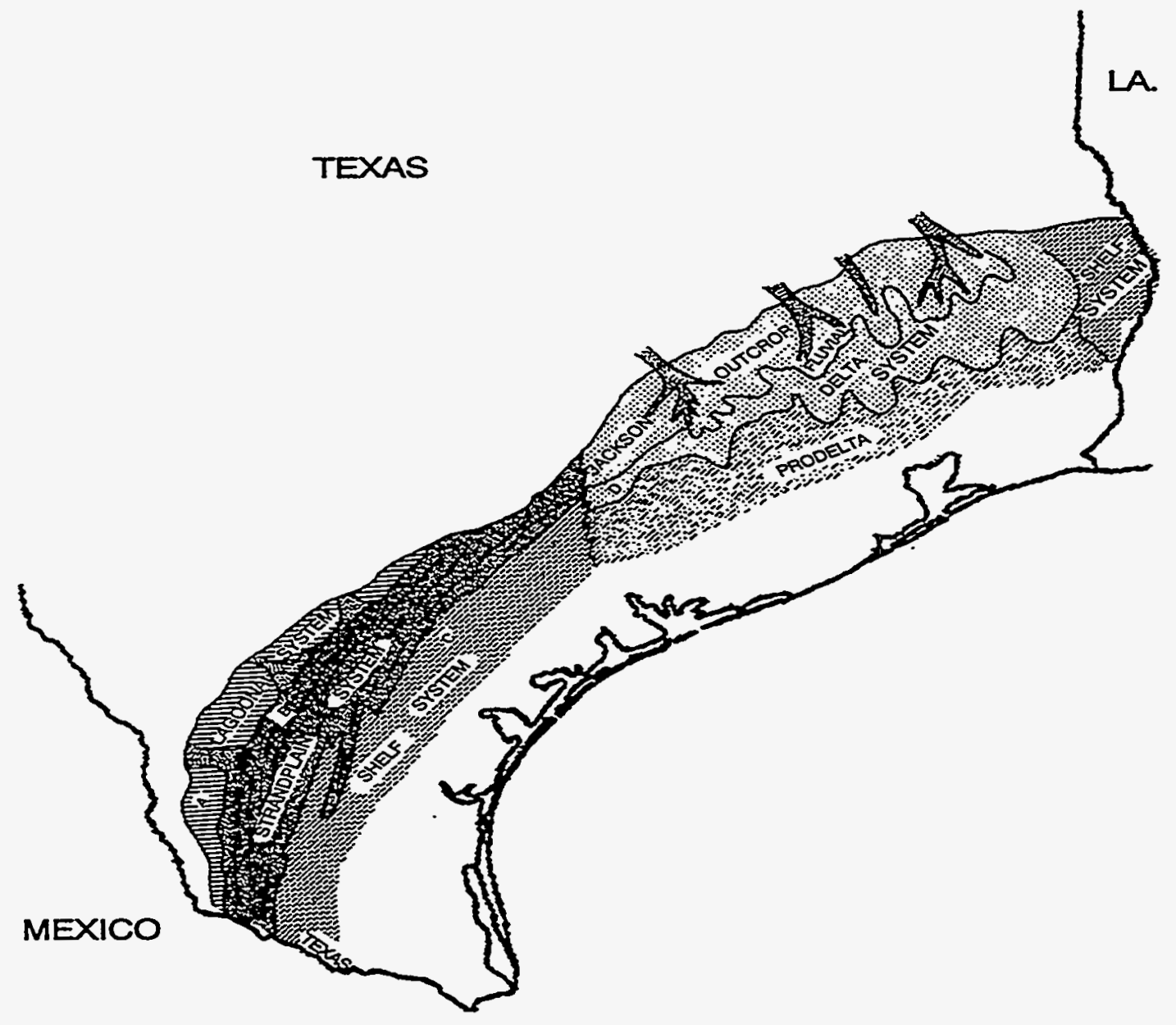

Figure 3.9 Paleoenvironments Associated with Deposition of Texas Class 4 Reservoirs in the Jackson Play (Modified After: Fisher etal., 1970, p. 240) 
time. With relatively stable strandlines, sands could build up to substantial thicknesses. With greater amounts of sediment reaching the embayment, beaches and barrier islands prograded, forming relatively thick, relatively widespread, tabular sand bodies. These parameters came closer to matching those that had prevailed in the best Frio reservoirs. With a sufficient amount of relatively coarse sediment and stable coasts controlled by growth-faulting, good reservoir units were able to form in the Rio Grande Embayment during Jackson time.

Oil in Jackson reservoirs is primarily trapped by updip pinch-out of strandplain/barrier island sands and, secondarily, by minor normal (growth) faults (Galloway et al., 1983). Some stratigraphic pinch-outs occur surprisingly close to the outcrop of the formation in south Texas. Production can be as shallow as 150 feet below the surface. A stratigraphic "pinch-out" may be the location where the sand actually ends or may represent the area where sand can still be seen on well logs, but where permeability drops too low for continued oil migration and production.

\subsubsection{Reservoir Characteristics, Models, and Major Controls on Production}

The best reservoirs in the barrier core sands tend to be on structurally high areas, on rollover anticlines, or against faults. In addition to the major barrier core sands, there are a number of smaller, less productive, stratigraphic-pinch-out traps which formed on the strandplain shoreface and on fore-barrier and back-barrier slopes. These units tend to occur as thin sheets of limited extent. Laterally, they pinch out into finer-grained units and shales. Many of these shoreface and lagoon-area fields may be one-well pools.

The main Jackson reservoir model matches that of the previously described Frio sands. The high-energy setting along the barrier islands created the best reservoir sands. These bodies are elongate parallel to the paleo-coast. Thick, massive sands formed in the core-zones of the barrier islands. Thinner, less-continuous sands were deposited on the seaward faces of the bars and beaches. Tidal inlets, channels, and washover fans cut across the barriers at irregular intervals. Lagoons containing finer-grained sediments occupied the area between the barriers and strandlines.

Logs taken through the main barrier-core sands show apparently uniform, clean, massive sandstones. Lithologic features and structures within these massive bodies are generally difficult to distinguish and appear to be insignificant. Production experience in these reservoirs indicates that the sands are not as homogeneous as they appear. Single, massive sand bodies may contain two or more isolated productive units. Impermeable zones can create multiple reservoirs within a single sand (Galloway et al., 1983).

The difficulties in identifying the various reservoir compartments within the sand bodies are due to lack of ability to predict the occurrence of (1) minor clay/shale coatings deposited in the normal beach/barrier setting and (2) tidal inlets. It is easy to map long, large barriers as continuous features along the coast without recognizing inlet deposits in the intervals between wells. 


\subsubsection{Production Characteristics}

Jackson strandplain/barrier island oil production was originally discovered and developed in the 1920s. Most Jackson reservoirs have been found in the shallow subsurface, relatively near outcrops, and have been abandoned or are nearing depletion.

Almost 300 productive oil and gas fields are in the Jackson trend (Fisher et al., 1970). This number includes both small one-well fields and many fields that have been drilled primarily for natural gas, not oil. Approximately 50 of these fields were large, capable of producing in excess of one million barrels of oil. Ten fields have already passed the 10 million barrel mark in oil production. The World War II era marked the heyday of Jackson exploration activity. Most reservoirs discovered since that time have been relatively small (Fisher et al., 1970).

The best Jackson oil production has come from fields in the counties in the Rio Grande Embayment (see Figure 3.8). The better fields tend to be either in the center or on the landwardside of the trend. Barrier-face reservoirs on the Gulf side of the trend tend to have smaller total and recoverable reserves. In the better fields, wells can produce between 10,000 and 20,000 barrels of oil per acre (Fisher et al., 1970). Most of the recent Jackson activity has centered on exploration in peripheral areas surrounding the main strandplain/barrier island trend. For the 41 Jackson strandplain/ barrier island reservoirs listed in TORIS, ROIP is 1.25 billion barrels and ultimate recovery efficiency is $34 \%$ (Table 3.2). This ultimate recovery is based on a reported OOIP of 1.85 billion barrels of which approximately 0.6 billions barrels have been recovered.

Average Jackson reservoir depth is 2,700 feet and average net pay thickness is 16 feet. Analysis of TORIS database reservoir parameters indicates that reservoirs of the Jackson Play have a porosity of $30 \%$ with an initial oil saturation of $65 \%$ and an average permeability of $650 \mathrm{mD}$. The production-weighted-average recovery efficiency calculated for the Jackson is 39\% (Fisher et al., 1970). Thickness-weighted-average porosity for the play is $31 \%$, and the permeability is $1,103 \mathrm{mD}$ (Dutton and Garrett, 1985).

\subsubsection{Improved Oil Recovery Projects}

Oil trapped stratigraphically updip in the thinner, poorer quality lagoon-associated sands, the primary trapping mechanism in this play, produces mainly by solution-gas drive. Gas pressure maintenance and waterflooding have been the dominant secondary recovery methods. Several IOR processes have been tested in the play. For those Class 4 fields listed in TORIS, eleven IOR projects are noted in nine fields (Table 3.6) (Pautz et al., 1992; Galloway et al., 1983). Although the surfactant and miscible gas processes have been tested, polymer and thermal processes have been the dominant processes. Although TORIS data indicate an average oil gravity of $29^{\circ}$ API in the play, the IOR projects have focused on reservoirs with oil gravity in the $20^{\circ}$ to $25^{\circ}$ API range.

Galloway et al. (1983) reported five thermal projects and, although their listing did not distinguish between steam and in situ combustion, they reported steam as the major process. For thermal processes, the Enhanced Oil Recovery Database (Pautz et al., 1992) contains data on only the in situ combustion project in the Government Wells North field. Additional data regarding this project are reported by Casey (1969). 


\begin{tabular}{|c|c|c|c|c|c|c|}
\hline \multicolumn{7}{|c|}{ 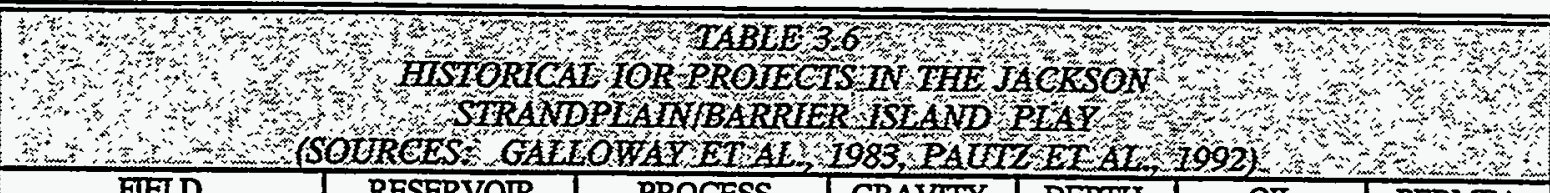 } \\
\hline FIEID & RESERVOIR & PROCESS & $\begin{array}{c}\text { GRAVITY, } \\
\text { 'API }\end{array}$ & $\begin{array}{l}\text { DEPTH, } \\
\text { FEET }\end{array}$ & $\begin{array}{c}\text { OII } \\
\text { COLUMN, } \\
\text { FEET }\end{array}$ & $\begin{array}{c}\text { PERMEA- } \\
\text { BIITY, mD }\end{array}$ \\
\hline ESCOBAS & MIRANDO & THERMAL & 23 & 1,200 & 70 & 500 \\
\hline $\begin{array}{l}\text { GOVERNMENT } \\
\text { WELIS, N. }\end{array}$ & $\begin{array}{l}\text { GOVERNMENT } \\
\text { WELS }\end{array}$ & $\begin{array}{l}\text { THERMAL(1)\& } \\
\text { POLYMER }\end{array}$ & 21 & 2,200 & 60 & 800 \\
\hline HOFFMAN & DOUGHERTY & $\begin{array}{l}\text { POLYMER \& } \\
\text { SURFACTANT } \\
\text { (1) }\end{array}$ & 23 & 2,000 & 250 & 757 \\
\hline LOPEZ & MIRANDO & THERMAL & 22 & 2,200 & 70 & 250 \\
\hline MIRANDO CITY & MIRANDO & THERMAL & $\overline{21}$ & 1,600 & 35 & 1,600 \\
\hline OTERN & PETTUS & THERMAL & 28 & 2,700 & 200 & 286 \\
\hline PIEDRELUMBRE & $\begin{array}{l}\text { GOVERNMENT } \\
\text { WETIS }\end{array}$ & GAS & 22 & 1,900 & 65 & 300 \\
\hline RANDADO & COLE & GAS(1,2) & 20 & 1,270 & & 2,300 \\
\hline SEVENTY-SIX, W & COLE & POLYMER $(1,2)$ & 20 & 1,350 & & 1,200 \\
\hline
\end{tabular}

(I) Projects listed in Enhanced Oil Recovery Database.

(2) Reservoir parameters from Enhanced Oil Recovery Database (Pautz et al. (1992)

Mobil started their in situ combustion project in the Government Wells North field in 1962. At the time of ignition, the project area was producing at a $98 \%$ watercut. By 1969, about 500,000 barrels of incremental oil had been recovered with nearly all of this oil produced ahead of the burning front (Casey, 1969). About 1,000 acre-feet were encompassed by the burning front. As the burning front passed by the producing wells, they were converted to water injection. Oxygen utilization was considered good: only $12 \%$ of the injected oxygen was lost to low temperature oxidation (Casey, 1969). Excessive erosion, emulsification, or sand production problems typically associated with in situ combustion were not observed in this project (Casey, 1969).

Polymer projects are noted in the Government Wells North (Government Wells sand), Hoffman (Daugherty sand), and Seventy-Six West (Cole sand) fields. Specific project data are available only on the project in the Seventy-Six West field. Viscosity of the $20^{\circ} \mathrm{API}$ oil is $21 \mathrm{cP}$ and permeability is $1,200 \mathrm{mD}$. The project was a small, 60 acre, four well project (Pautz et al., 1992).

Pautz et al. (1992) reported a 63-acre surfactant project in the Hoffman (Dougherty sand) field. The project was conducted by Edwin L. Cox. Viscosity of the $24^{\circ}$ API oil was $4 \mathrm{cP}$ and permeability was $750 \mathrm{mD}$. Reservoir salinity was reported at 12,000 ppm (Pautz et al., 1992).

Details on the gas injection projects are also limited. Pautz et al. (1992) reported the Randado field project as a miscible gas displacement. Galloway et al. (1983) reported the Piedre Lumbre field project as a liquefied petroleum gas flood. 


\subsection{Cretaceous, Salt-Related Play}

\subsubsection{Play Description}

The East Texas Salt Basin (Figure 3.8) is a structural depression in the northeastern corner of Texas, located between the Ouachita Fold Belt and the Sabine Arch. Class 4 reservoirs in Texas include a series of Cretaceous-age strandplain/barrier island reservoirs in the East Texas Basin, a salt depocenter during the Jurassic Period. Within the Basin are two strandplain/barrier island plays; the Lower Cretaceous Paluxy Play, in which trapping mechanisms in many reservoirs are related to salt movement, and the Upper Cretaceous Woodbine Play located south of the main area of salt movement in the Basin (Figure 3.1 and Figure 3.4). The southern end of the basin was open to deeper water during the Jurassic. The salt-related plays occur within the low where Jurassic-age salts attain considerable thickness.

Most of the salt-related, barrier-island sandstone production is found in the Paluxy formation. The sandstones accumulated during periods of clastic influx from the north, and formed part of a well-developed barrier island complex off the Paluxy coastline (Caughey, 1977). Paluxy fluvialdeltaic sediments were deposited in a broad band along the modern Red River on the Texas-Oklahoma border (Caughey, 1977). To the south within Texas, a lagoonal environment covered the area north of the barrier island complex in an east-west band eastward into Louisiana.

Caughey (1977) recognized two reservoir classes or subplays producing from distinct subfacies in the barrier island complex: a proximal subfacies class producing from thick (barrier core) sands with only minor shale interbeds flanked on the south by a distal subfacies class producing from thin, discontinuous sands in a predominantly shale or mudstone section.

During and after Paluxy deposition, Jurassic salt masses flowed and rose into high-relief salt domes and low relief salt pillows or turtle-shaped masses. Salt-induced tectonic activity around the salt domes was too extreme for the formation of good quality reservoirs in the Paluxy formation, but the more moderate salt structures, i.e., pillows and turtle-shaped masses, produced the proper setting for the creation of oil traps. Following lithification, the Paluxy barrier island sands settled over these salt-cored structures. A series of folded and faulted anticlines formed, and oil has migrated into these local highs creating a series of structurally controlled reservoirs. In many of the fields, oil is trapped against internal faults. Production from this portion of the Paluxy requires a good understanding of the tectonics of the underlying salt structures.

West of the barrier island complex, the Paluxy forms a 50-mile-wide strandplain belt. This belt runs north-south from Oklahoma into central Texas just downdip from the Paluxy outcrop. The Paluxy has generally not been productive along this trend. The sands in the strandplain lie west of the main salt basin and have not been significantly influenced by salt tectonics.

\subsubsection{Reservoir Characteristics, Models, and Major Controls on Production}

Paluxy salt-related reservoirs commonly are associated with anticlinal structures and are segmented by faults into compartments often having different water levels (Galloway et al., 1983). Some fields have asphaltic layers that further disrupt internal continuity (Galloway et al., 1983). Reservoirs in the proximal barrier subfacies contain clean, porous sandstones often in well-connected reservoirs that display common oil-water contacts and uniform water encroachment during 
primary production (Caughey, 1977). Structural closure is a key element of the trapping mechanism, because the sandy nature of lagoonal sediments results in ineffective seals for stratigraphic traps. However, lateral variations in reservoir continuity resulting from thin lenticular and local producing sands is a distinct characteristic of distal subfacies reservoirs (Caughey, 1977). Both stratigraphic and structural traps are common, but most reservoirs show at least some structural modification.

Only one small reservoir produces from a shallow, 500 feet deep, thin sandstone basinward from the main Paluxy strandplain to the west of the salt-related barrier island trend. These strandplain deposits connect updip with outcrops and are saturated with fresh water (Caughey, 1977).

In the Upper Cretaceous Woodbine, barrier island reservoirs predominate, but mud-rich strandplain deposits with elongate sand bodies form significant reservoirs also (Oliver, 1971). The favored situation for maximum production is aggradational stacking of barrier island deposits (Oliver, 1971).

The Upper Cretaceous Woodbine sands (Figure 3.4) have produced large amounts of oil, but only a limited amount of this oil has come from salt-related structures and strandplain or barrierisland sands (Oliver, 1971). A series of Woodbine strandline sands are productive where the sands have draped over salt cores. Reservoirs occur high on salt structures, against salt-related faults, and in stratigraphic, pinch-out traps on the flanks of salt-related structures.

\subsubsection{Production Characteristics}

The Cretaceous, Salt-Related Play contains $8.6 \%$ of the total ROIP for Texas Class 4 reservoirs listed in the TORIS database. OOIP and ROIP are 957 and 519 million barrels respectively corresponding to an estimated ultimate recovery factor of $43 \%$ of the OOIP. For those reservoirs listed in the TORIS database, reservoir depth averages about 5,700 feet. Average net pay is 25 feet, and permeability and porosity average $570 \mathrm{mD}$ and $22 \%$, respectively. Oil gravity averages $32^{\circ}$ API ranging from $14^{\circ} \mathrm{API}$ to $69^{\circ} \mathrm{API}$. Water and solution-gas drive are the main drive mechanisms during primary production.

Most (80\%) of the Cretaceous salt-related strandplain/barrier island sandstone production is expected to come from Paluxy formation reservoirs (Galloway et al., 1983). Wells through the Paluxy generally intercept multiple pays. Multiple-reservoir zones can be encountered within a single, massive sand, due to internal permeability barriers. The proximal or near-shore (northern) barrier sands often range between 40 and 100 feet in thickness. To the south, the distal or fartheroffshore Paluxy barrier sands generally are between 3 and 60 feet thick.

Proximal barrier island deposits are expected to yield $64 \%$ of the recoverable Paluxy oil. Depths of the proximal sands range from 4,400 to 6,800 feet, with most of the production coming from the deeper units (Caughey, 1977). Individual reservoir thicknesses generally are between 10 and 55 feet. Aggregate thicknesses can be from 100 to 250 feet, plus.

The distal barrier island Paluxy reservoirs range from 2,300 to 9,600 feet in depth (Caughey, 1977). Most distal reservoirs are between 3 and 50 feet in thickness with thicker sections of silts and interbedded mudstones. Sand sizes are generally fine. Reservoirs form both on structures and at stratigraphic pinch-outs. The distal sands produce a mixture of oil, natural gas, and condensate. 


\subsubsection{Improved Oil Recovery Projects}

Tertiary recovery processes were implemented in several reservoirs of the Cretaceous SaltRelated Play in Texas. Polymer flooding, alkaline-polymer, in situ combustion, steam, and $\mathrm{CO}_{2}$ miscible processes have been employed in the play. Parameters for active projects are presented in Table 3.7.

\subsubsection{Polymer Flooding}

In 1980, Sun E\&P Co. initiated a polymer injection flood at Hitts Lake field, after successfully identifying a suitable polymer through laboratory studies. The field was discovered in 1953, and 35 wells were completed in the Paluxy at an average depth of 7,200 feet. The field produced $30 \%$ of the OOIP by primary recovery, and attempts to enhance recovery through waterflooding and gas injection failed.

As a result of the polymer flood, the total field production increased from 400 to 900 barrels of oil per day (BOPD). In 1984, the incremental oil recovered was in excess of 150,000 barrels and the economics were reported to be very favorable (Greaves et al., 1984).

\subsubsection{Alkaline-Polymer Projects}

Mitchell Energy has conducted alkaline-polymer projects in two units, the Alba SEFB and Alba NE Units, in the Subclarksville reservoir in the Alba field. Higher acid contents in the $15^{\circ}$ to $16^{\circ}$ API gravity crudes favored application of the alkaline-polymer process. The 22-well Alba SEFB

\begin{tabular}{|c|c|c|c|c|c|c|}
\hline \multicolumn{7}{|c|}{ 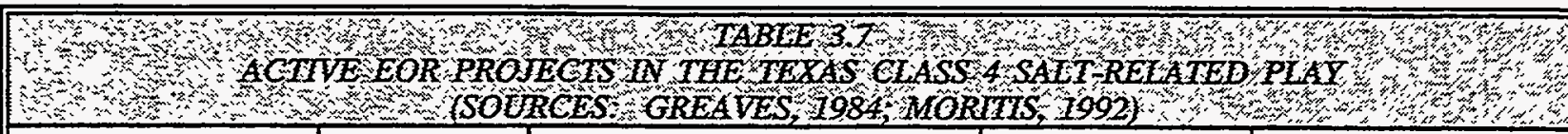 } \\
\hline \multirow[b]{2}{*}{ PARAMETER } & \multirow{2}{*}{$\begin{array}{l}\text { POLYMER } \\
\text { HITTSLAKE } \\
\text { PALUXY } \\
\text { ORYX(SUN) }\end{array}$} & \multicolumn{2}{|c|}{$\begin{array}{l}\text { ALKALINE-POLYMER } \\
\text { ALBA SUBCLARKSVILLE } \\
\text { MTCHELL ENERGY PROJECTS }\end{array}$} & \multirow[t]{2}{*}{$\begin{array}{c}\text { INSITU } \\
\text { COMBUSTION } \\
\text { FOREST HIIL } \\
\text { HARRIS } \\
\text { GREENWICH OIL }\end{array}$} & \multicolumn{2}{|c|}{$\begin{array}{l}\text { STEAM } \\
\text { CAMP HIIL } \\
\text { ENERCAP PROJECTS }\end{array}$} \\
\hline & & ALBA SEFB & ALBANE & & No. 1 & No. 2 \\
\hline START DATE & 1980 & 1972 & 1980 & 1976 & 1989 & 1990 \\
\hline SIZE, ACRES & 716 & 731 & 410 & 1,900 & 25 & 33 \\
\hline NO. WEILS & 26 & 22 & 12 & 121 & 37 & 46 \\
\hline DEPTH, FT & 7,301 & 4,200 & 4,100 & 5,000 & 400 & 425 \\
\hline POROSITY, \% & 19 & 23 & 21 & 28 & 37 & 37 \\
\hline PERMEABILTTY, $\mathrm{mD}$ & 300 & 525 & 471 & 950 & 2,500 & 2,500 \\
\hline GRAVITY, API & 26 & 16 & 15 & 10 & 18 & 18 \\
\hline $\begin{array}{l}\text { EOR PRODUCTION, } \\
\text { BOPD }\end{array}$ & $\begin{array}{r}900 \\
(1984) \\
\end{array}$ & $\begin{array}{c}140 \\
(1992) \\
\end{array}$ & $\begin{array}{r}69 \\
(1992) \\
\end{array}$ & $\begin{array}{r}400 \\
(1992) \\
\end{array}$ & $\begin{array}{c}30 \\
(1992)\end{array}$ & NA \\
\hline
\end{tabular}


project began in 1972; the reported production volume due to the alkaline-polymer process was 140 BOPD in 1992 (Moritis, 1992). Alkaline-polymer production response in the smaller (12 well), later (1980) Alba NE project was 70 BOPD in 1992.

\subsubsection{In Situ Combustion}

Pautz et al. (1992) reported two in situ combustion projects in the Slocum field in the Carrizo sand. In these projects, oil gravity was about $18^{\circ} \mathrm{API}$ and viscosity was $1,200 \mathrm{cP}$. Reservoir depth is less than 600 feet. Both projects were conducted by Petromac (Goldking). Tertiary oil production in the larger, nearly 80 -well project peaked at about $130 \mathrm{BOPD}$, while production in the smaller 27-well project was about 70 BOPD (Pautz et al., 1992). Performance of the smaller project was termed promising.

Forest Hill Co., as operator for Greenwich Oil Corporation, is using oxygen-enriched in situ combustion in the Harris sand in the Forest Hill field. Initial reservoir development in this field began in 1964. Crude viscosity is $1,000 \mathrm{cP}$ and gravity is $10^{\circ} \mathrm{API}$. The reservoir is 4,800 feet deep, has $28 \%$ porosity, and $626 \mathrm{mD}$ permeability (Hvizdos et al., 1982). OOIP in the 1950 -acre unit was about 39 million barrels, or 1,362 barrels per acre-foot (Bleakley, 1987).

A steam project was tried in the 1960s (Hvizdos et al., 1982), followed by air injection for in situ combustion in 1976. Beginning in 1980, Forest Hill Co. evaluated the effectiveness of oxygenenriched air injection. Oxygen concentration in a single injection well was varied from 21 to 90 volume percent. Results indicated (1) oxygen could be safely injected, (2) oxygen is cheaper than air over a wide range of pressures and flow rates, (3) oxygen of at least $80 \%$ purity should be used, and (4) average specific productivity of wells in the $90 \%$ oxygen pattern was higher than in wells in air injection patterns (Hvizdos et al., 1982). As a result, Forest Hill Co. switched to injecting 90\% oxygen. Development plans in 1987 foresaw 100 producing wells and 25 injection wells when the project was fully developed. Project goals were to reach a producing rate of $1,750 \mathrm{BOPD}$, and to recover $45 \%$ of the OOIP (Bleakley, 1987). Cumulative recovery through 1980 was only 1.26 million barrels, or $3.2 \%$ of the OOIP (Hvizdos, et al, 1982).

\subsubsection{Steam Projects}

Steam injection was tested by Shell Oil Co. in the Slocum field in northeast Texas. Production of $19^{\circ} \mathrm{API}$ oil ranging in viscosity from 1,000 to $3,000 \mathrm{cP}$ is from the shallow Carrizo formation (500 to 600 feet). The sand is generally very clean, having a permeability of about $3,500 \mathrm{mD}$. The viscosity of the oil at reservoir temperature $\left(75^{\circ} \mathrm{F}\right)$ allows only marginal primary recovery. The viscosity-temperature behavior of the oil is such that its viscosity is reduced by a factor of more than 100 when the temperature is increased to $350^{\circ} \mathrm{F}$, as exhibited in Figure 3.10 (Hall and Bowman, 1973). Such behavior suggests that oil could be produced successfully with thermal recovery processes. Other favorable conditions for thermal recovery were the shallow depth of the accumulation, the high oil saturation (65\%), and the availability of high-quality fresh water for generating steam or hot water. 


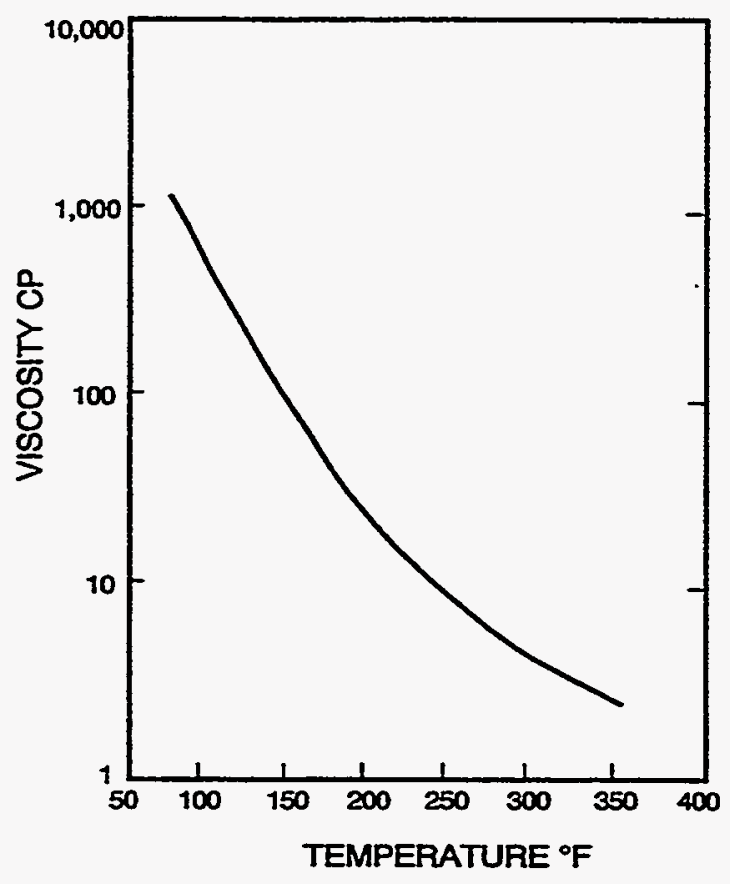

Figure 3.10 Viscosity-Temperature Relationship for Oil from the Texas Slocum Reservoir, a Class 4 Reservoir from the Cretaceous SaltRelated Play (Source: Hall and Bowman, 1973)

A 1/4-acre pilot was conducted with a normal five-spot pattern having four injectors and a central producer. Encouraged by the $40 \%$ recovery of the oil-in-place within the pilot area, Shell expanded the project to 20 patterns by 1969 . Each pattern was a 5.65-acre, 13-spot pattern. Both production and injection wells were completed a few feet into the fresh water zone beneath the reservoir. Through December 1969, the oil attributed to the initial 7-pattern project was 1.2 million barrels representing a recovery of $36 \%$ of the original oil-in-place. The total thermal recovery from the field was 1.4 million barrels.

However, numerous difficulties were associated with this process ranging from: (1) productivity decline in some wells due to the encroachment of the steam front as it moved out to the more distant wells, (i.e., excessive steam production and reduced oil recovery); (2) oil treating due to changes in production stream behavior; (3) organic solids production along with oil; and (4) production of hydrogen sulfide gas due to the increase in produced fluid temperature.

Furthermore, the large quantities of steam necessary for this project have hampered its economic attractiveness. Solutions to most of these problems were developed which led to a significant improvement in the oil-steam ratio, and hence, improvement in the associated profitability.

Additional steam injection projects were designed for the Slocum field between 1971 and 1975 with an addition of a total of 28 inverted 13-spot patterns. The project was terminated in 1977 due to the breakthrough of steam in most wells, high water production, and reduced residual oil saturation in areas effectively steam flooded. During the life of the project, 51 million barrels of steam 
and 25 million barrels of water were injected to produce 7 million barrels of oil and 193 million barrels of water.

Currently, conventional steamflood projects in the Camp Hill field in the Carrizo reservoir are being operated by Enercap Corporation. In 1989, the peak oil production due to this process was reported at $300 \mathrm{BOPD}$.

\subsubsection{5 $\quad \mathrm{CO}_{2}$ Miscible Project}

Chevron conducted a small $\mathrm{CO}_{2}$ miscible pilot in the Pittsburg field (Pittsburg sand) in the mid1980s. With a reservoir depth of 8,000 feet and oil gravity of $41^{\circ} \mathrm{API}$, miscibility was possible. Permeability was reported as $2 \mathrm{mD}$ (Pautz et al., 1992). Production response was not reported.

\subsection{IOR Activity in Other Plays}

Another in situ combustion project was carried out in the Trix-Liz Woodbine "C" reservoir in the Woodbine Fault Line Play. The Trix-Liz Woodbine "C" Zone is Cretaceous in age, occurs at an average depth of 3,650 feet, and has an average thickness of 9 feet. Core and log analyses indicated an average porosity of $28 \%$ and an average connate water saturation of $35 \%$. Primary production from the reservoir accounted for $15 \%$ of the OOIP. The primary drive mechanism was gravity drainage supported by a weak natural edge-water drive (Buchwald et al., 1973).

The sensitivity of the Trix-Liz reservoir to the freshness of injected water placed limitations on the choice of secondary recovery methods. A review of reservoir properties revealed that an in situ combustion process had the greatest probability of being successful. In 1968 the first well was ignited in the reservoir, followed in 1969 by ignition in a second well. The merging of the two burn zones from the ignited wells was accomplished after 4 years of in situ combustion.

Oil recovery from the Trix-Liz "C" reservoir as of January 1,1972 was 650,000 barrels. Of this volume, 419,000 barrels represented primary recovery production. In situ combustion contributed 230,000 barrels of oil. The ultimate recovery of oil from this reservoir by primary production and by the in situ combustion process is estimated to be $60 \%$ of the OOIP.

\subsection{References}

Bleakley, W.B., 1987, Making new production technology work for you: Petroleum Engineer International, vol. 59, No. 1, January, p. 20-22.

Buchwald, R.W., W.C. Hardy, and G.S. Neinast, 1973, Case histories of three in-situ combustion projects: Journal of Petroleum Technology, vol. 25, No. 7, July, p.784-792.

Casey, TJ., 1969, A field test of in-situ combustion process in a near depleted water drive reservoir: SPE 2520 44th Annual Technical Conference, Denver, Colorado. 
Caughey, C. A., 1977, Depositional systems in the Paluxy formation: The University of Texas at Austin, Bureau of Economic Geology, Geologic Circular 77-8, 60 p.

Dutton, S. P. and C.M. Garrett, Jr., 1985, Abandoned oil fields of the Texas Gulf Coast and the East Texas Basin: The University of Texas at Austin, Bureau of Economic Geology, Geologic Circular 85-3, 48 p.

Fisher, W.L. C.V. Proctor, Jr., W.E. Galloway, and J.S. Nagle, 1970, Depositional systems in the Jackson Group of Texas-Their relationship to oil, gas, and uranium: The University of Texas at Austin, Bureau of Economic Geology, Geologic Circular 70-4, 28 p.

Galloway, W.E. and E.S. Cheng, 1985, Reservoir facies architecture in a microtidal barrier system -- Frio formation, Texas Gulf Coast: The University of Texas at Austin, Bureau of Economic Geology, Report of Investigations No. 144, 36 p.

Galloway, W.E., T.E. Ewing, C.M. Garett, N. Tyler, and D.G. Bebout, 1983, Atlas of major Texas oil reservoirs: The University of Texas at Austin, Bureau of Economic Geology Special Publication, 139 p.

Greaves, B.L., R.N. Marshall, and J.H. Thompson, 1984, Hitts Lake Unit polymer project: SPE 13123 59th Annual Technical Conference, Houston, Texas.

Hall, A.L. and R.W. Bowman, 1973, Operation and performance of the Slocum thermal recovery project: Journ. of Petrol. Techn., April, p. 402-408.

Hvizdos, L.J., J.V. Howard, and G.W. Roberts, 1982, Enhanced oil recovery via oxygenenriched in-situ combustion: test results from the Forest Hill field in Texas: SPE 11218 57th Annual Fall Technical Conference, New Orleans, Louisiana.

ICF and BEG (The University of Texas at Austin, Bureau of Economic Geology), 1990, An assessment of the reserve growth potential of the Frio Barrier-Strandplain Play in Texas: Department of Energy Report DOE/BC/14000-6, August, 128 p.

Moritis, G., 1992, EOR increases $24 \%$ worldwide; claims $10 \%$ of U.S. production: Oil and Gas Journal, vol. 90 , No. 16, p. 51-79.

Oliver, W.B., 1971, Depositional systems in the Woodbine Formation (Upper Cretaceous), northeast Texas: The University of Texas at Austin, Bureau of Economic Geology, Report of Investigations No. 73, 28 p.

Tyler, N., W.E. Galloway, C.M. Garrett, Jr., and T.E. Ewing, 1984, Oil accumulation production characteristics, and targets for additional recovery in major oil reservoirs of Texas: The University of Texas at Austin, Bureau of Economic Geology, Geologic Circular 84-2, $32 \mathrm{p}$. 


\section{CHAPTER 4 MAJOR OKLAHOMA STRANDPLAIN/BARRIER ISLAND PLAYS}

The strandplain/barrier island reservoirs in Oklahoma represent over 30\% of the Class 4 remaining oil-in-place (ROIP) in the country, as defined in the DOE Tertiary Oil Recovery Information System (TORIS). The majority of the Class 4 resource in Oklahoma is found in three plays: the southern Oklahoma Desmoinesian, the southern Oklahoma Bromide, and Arkoma Morrowan Plays. This chapter describes the reservoir and production characteristics of these three plays and includes discussions of the unique geological context that leads to hydrocarbon trapping within each play.

Oklahoma Class 4 production has been significantly impacted by improved oil recovery, particularly by polymer activity in the southern Oklahoma Desmoinesian and Missourian Plays. Limited thermal operations in the Deese reservoir in the southern Oklahoma Desmoinesian Play have not significantly impacted IOR production. Few IOR projects have been conducted in other Oklahoma Class 4 reservoirs. These projects, even when successful, have not led to widespread application.

\subsection{Overview of Oklahoma Plays}

Oklahoma contains nearly 6 billion barrels of remaining oil-in-place (ROIP) in Class 4 reservoirs. This volume represents over $30 \%$ of the ROIP for Class 4 reservoirs listed in the TORIS database (Table 4.1). Cumulative recovery is $37 \%$ of the OOIP. Estimated remaining reserves with current operations are 428 million barrels (versus cumulative production of 3.8 billion barrels).

Major productive Class 4 reservoirs in Oklahoma are generally limited to a band across the southern portion of the state. Most of the Oklahoma strandplain/barrier island oil deposits occur in Bromide (Ordovician) and Desmoinesian (Pennsylvanian) Plays in the Ardmore Basin, a narrow depression to the southeast of the Anadarko Basin (Figure 4.1). Limited Class 4 oil production also comes from a Morrowan (Pennsylvanian) Play on the western end of the Arkoma Basin. These three plays contain nearly $60 \%$ of the Class 4 ROIP in Oklahoma.

During the early Paleozoic, the southern Oklahoma site of the Ardmore and Anadarko Basins was part of a widespread shallow shelf on the southern margin of the North American Craton. In Middle Ordovician time, carbonate deposition was interrupted by an influx of terrigenous clastics from the east and southeast. Deep water of the Southern Oklahoma Aulacogen was well to the southwest of this area, and a variety of clastic depositional environments including Bromide strandplain and barrier island environments migrated back and forth across the shelf in response to minor changes in sediment supply and/or relative sea level.

Shallow shelf deposition continued for some time, but by the end of Mississippian time, the area had been uplifted and part of its sedimentary fill removed by erosion. Regional compression caused by plate tectonic movement resulted in downwarping in the Ardmore Basin and in the Anadarko Basin area north of the uplifting Wichita mountains. Shallow water clastic 


\begin{tabular}{|c|c|c|c|c|}
\hline PLAY & $\begin{array}{c}\text { ORIGINAL } \\
\text { OIL-IN-PLACE } \\
\text { MMBO }\end{array}$ & $\begin{array}{c}\text { CUMULATIVE } \\
\text { RECOVERY } \\
\text { MMBO }\end{array}$ & $\begin{array}{c}\text { REMAINING } \\
\text { OIL-IN-PLACE } \\
\text { MMBO }\end{array}$ & $\begin{array}{c}\text { NUMBER } \\
\text { OF } \\
\text { RESERVOIRS }\end{array}$ \\
\hline S. OK DESMOINESIAN & 2,783 & 943 & 1,612 & 10 \\
\hline S. OK BROMIDE & 1,260 & 303 & 947 & 8 \\
\hline ARKOMA MORROWAN & 1,323 & 423 & 854 & 8 \\
\hline SUBTOTAL LARGEST PLAYS & 5,366 & 1,669 & 3,413 & 26 \\
\hline NEMAHA RIDGE ORDOVICIAN & 1,399 & 784 & 607 & 4 \\
\hline S. OK MISSOURIAN & 1,135 & 494 & 575 & 4 \\
\hline SEMINOLE PLATFORM WLCOX & 1,012 & 453 & 542 & 4 \\
\hline SE ANADARKO WOLFCAMPIAN & 409 & 103 & 301 & 2 \\
\hline ANADARKO BASIN MISSOURIAN & 265 & 95 & 149 & 1 \\
\hline ARKOMA SIMPSON & 155 & 50 & 93 & 2 \\
\hline S. OK SPRINGERAN & 118 & 32 & 81 & 1 \\
\hline CENTRAL OK ATOKAN & 62 & 22 & 39 & 1 \\
\hline S. OK PONTOTOC & 49 & 16 & 30 & 1 \\
\hline S. OK VIRGILIAN & 38 & 15 & 23 & 1 \\
\hline NE OK MISSOURIAN & 24 & 7 & 14 & 1 \\
\hline NE OK MISSISSIPPIAN & 27 & 15 & 12 & 1 \\
\hline NE OK DESMONIAN SS & 8 & 3 & 5 & 1 \\
\hline SE CIIATAUQUA & 3 & 1 & 2 & 1 \\
\hline SUBTOTAL OTHER OKLAHOMA & 4,705 & 2,088 & 2,473 & 25 \\
\hline $\begin{array}{l}\text { TOTAL OKLAHOMA } \\
\text { PLAYS }\end{array}$ & 10,071 & 3,757 & 5,885 & 51 \\
\hline
\end{tabular}

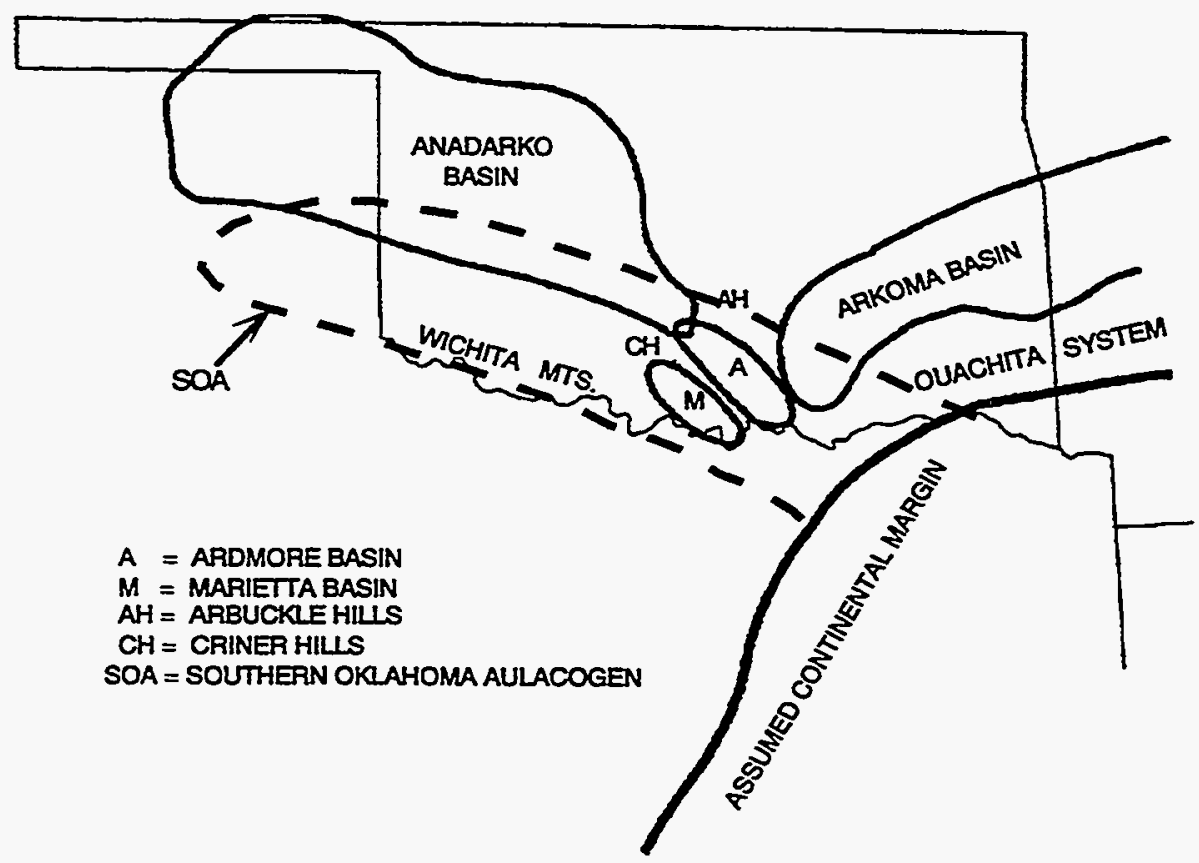

Figure 4.1 Structural Features of the Oklahoma Class 4 Production Areas (Modified from: Johnson et al., 1988; Sutherland, 1988; Haiduk, 1990) 
sedimentation with local sources to the southeast resumed and a variety of depositional environments including strandplain and barrier island environments are represented in the Desmoinesian sedimentary record.

The Arkoma Basin was also a site of shallow shelf deposition during the early Paleozoic. The Basin subsided through the Mississippian with development of the Ouachita Trough to the south which allowed accommodation of considerable thicknesses of deep-water sediments, but by the end of Mississippian time the region was uplifted and erosion was taking place. Early Pennsylvanian (Morrow) seas transgressed the area, and sources to the north and northeast provided sediments to build widespread strandplain, barrier island, and other shallow clastic deposits as sea level varied.

The ROIP volumes and average reservoir parameters, calculated from TORIS reservoir data, for the three major plays and all other Oklahoma strandplain/barrier island plays averaged together are summarized in Table 4.2. Oklahoma Class 4 production is primarily light oil from moderate depth reservoirs. Average net pay exceeds 50 feet and average permeability approaches $300 \mathrm{mD}$. Estimated ultimate recovery efficiency with current operations ranges from $29 \%$ of the OOIP in the Southern Oklahoma Bromide Play to $43 \%$ in the Southern Oklahoma Desmoinesian Play.

Production in Oklahoma Class 4 reservoirs is fairly evenly split between majors and independents. As shown in Figure 4.2, 48\% of the 1991 production volume was produced by majors, $45 \%$ by small independents, with the remaining $7 \%$ produced by midsize or large independents. Annual production volumes since 1970 from the three major plays are illustrated in Figure 4.3. Recent declines in all plays have relatively low slopes reflecting generally mature secondary production. Note that the production increase in the Southern Oklahoma Desmoinesian (Pennsylvanian) Play during the early 1980 s resulted primarily from several large polymer projects started during that time period.

\begin{tabular}{|c|c|c|c|c|c|}
\hline \multirow{3}{*}{\begin{tabular}{|l} 
and \\
PARAMETER \\
\end{tabular}} & 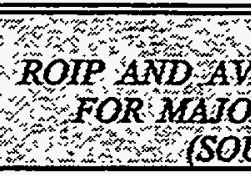 & $\begin{array}{l}\text { TABEE } \\
\text { GE RESER } \\
K E A H O M A \\
E B D O T O\end{array}$ & 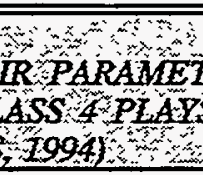 & 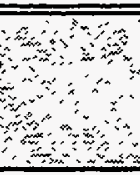 & 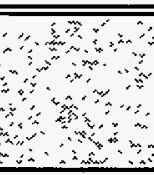 \\
\hline & \multicolumn{5}{|c|}{ MAJOR PLAYS } \\
\hline & $\begin{array}{c}\text { SOUTHERN } \\
\text { OKLAHOMA } \\
\text { DESMOINESIAN }\end{array}$ & $\begin{array}{c}\text { SOUTHERN } \\
\text { OKLAHOMA } \\
\text { BROMIDE }\end{array}$ & $\begin{array}{c}\text { ARKOMA } \\
\text { MORROWAN }\end{array}$ & $\begin{array}{c}\text { AUL } \\
\text { OTHERS }\end{array}$ & $\begin{array}{l}\text { OVERALL } \\
\text { AVERAGE }\end{array}$ \\
\hline $\begin{array}{l}\text { REMAINING OIL-IN- } \\
\text { PLACE, MMBO }\end{array}$ & 1,612 & 947 & 836 & 2,473 & \\
\hline NET PAY, FT & 31 & 106 & 48 & 55 & 60 \\
\hline POROSITY, \% & 19 & 16 & 18 & 18 & 18 \\
\hline $\begin{array}{l}\text { INITAL OIL } \\
\text { SATURATION, \% }\end{array}$ & 67 & 76 & 63 & 69 & 69 \\
\hline DEPTH, FT & 4,141 & 5,875 & 3,138 & 4,569 & 4,431 \\
\hline PERMEABIITY,mD & 234 & 431 & 223 & 281 & 292 \\
\hline GRAVITY, ${ }^{\circ} \mathrm{API}$ & 36 & 34 & 37 & 37 & 36 \\
\hline INITLAL PRESSURE, PSI & 1,778 & 2,583 & 1,244 & 1,731 & 1,834 \\
\hline ULTIMATE RECOVERY, \% & 43 & 29 & 38 & 42 & 38 \\
\hline
\end{tabular}




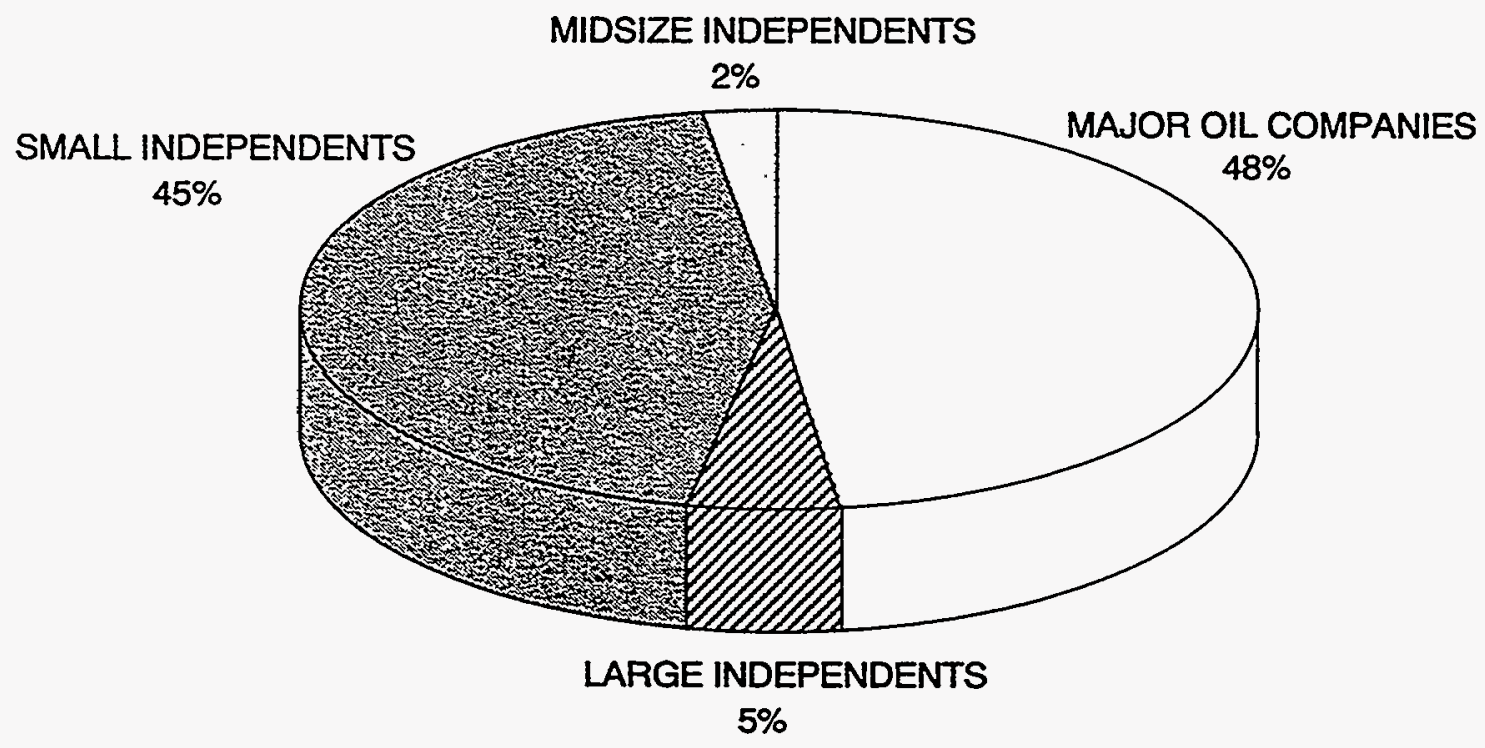

Figure 4.2 Operator Profile for Oklahoma Class 4 Reservoirs (Source: BPO TORIS, 1994)

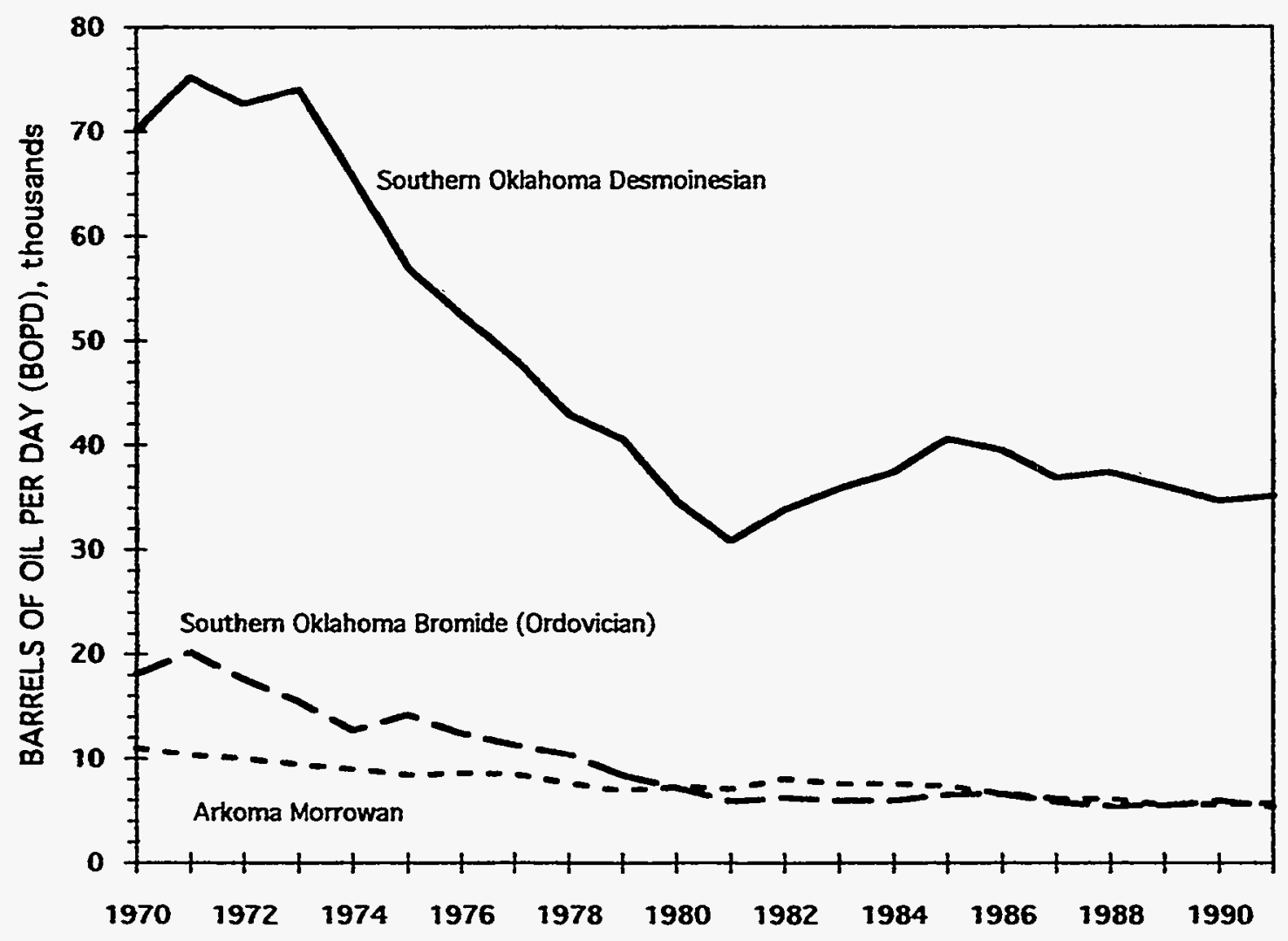

Figure 4:3 Historical Production for Major Oklahoma Class 4 Reservoirs (Source: BPO TORIS, 1994) 
Historical improved oil recovery (IOR) activity in Oklahoma Class 4 reservoirs is summerized in Table 4.3. Twenty-nine of 40 reported IOR projects have been in the Southern Oklahoma Desmoinesian (Pennsylvanian) Play. Six IOR projects are reported in the Southern Oklahoma Missourian Play. Although several processes have been tested, the polymer process has been the predominant process employed ( 33 of 40 or $83 \%$ of the projects).

\subsection{Southern Oklahoma Desmoinesian Play}

\subsubsection{Basin Development History}

Southern Oklahoma was the site of a deep aulacogen or rift valley during Late Precambrian and Early Cambrian times (Axtmann, 1983; Johnson et al., 1988) (Figure 4.1). This crustal break was the site of massive accumulation of sediments and igneous rocks in the Late Precambrian and through the start of the Paleozoic Era. The presence of this aulacogen was to have a significant impact on Pennsylvanian-age sedimentation and tectonics. Down-dropping in the area continued at a rapid rate throughout the Cambrian Period, then, progressively more slowly, into the Ordovician. Igneous activity was concentrated in the earliest phases of the rifting, and no significant mountain ranges or uplifts were produced in connection with the rifting during the early Paleozoic.

Cambro-Ordovician sediment influx into the low generally kept pace with the rate of subsidence of the aulacogen. With no major nearby clastic-sediment source, thick carbonate sections accumulated in a shallow-shelf environment. Occasional clastic pulses washed over southern Oklahoma, most derived from an eastern or southeastern source. Strandlines and barrier islands formed during some of these sediment influxes.

During Mississippian time, the southern rim of the continent became less stable. In southern Arkansas, eastern Texas, and Louisiana, the Ouachita Trough began to subside, and its rate of subsidence increased as the Mississippian went on. The inland sea still covered most of Oklahoma and the surrounding states, but by the close of the Mississippian Period, a broad regional uplift caused the seas to withdraw from the continental margin. Erosion removed the uppermost sedimentary cover across most of the region, with the exception of the deeper portions of the Anadarko and Ardmore Basins.

\begin{tabular}{|c|c|c|c|}
\hline BY PLAY & $\begin{array}{c}\text { NO. OF } \\
\text { PROJECTS }\end{array}$ & BY PROCESS & $\begin{array}{c}\text { NO. OF } \\
\text { PROJECTS }\end{array}$ \\
\hline S. OK DESMOINESIAN & 29 & POLYMER & 33 \\
\hline S. OK BROMIDE & 1 & STEAM & 4 \\
\hline ARKOMA MORROWAN & 1 & IN SITU & 1 \\
\hline S. OK MISSOURIAN & 6 & $\mathrm{CO}_{2}$ & 1 \\
\hline $\begin{array}{l}\text { SE ANADARKO } \\
\text { WOLFCAMPIAN }\end{array}$ & 3 & SURFACTANT & 1 \\
\hline TOTAL & 40 & TOTAL & 40 \\
\hline
\end{tabular}


During the Pennsylvanian Period, a new tectonic regime was established across the Oklahoma area. Compression was occurring as adjacent crustal plates encroached on the southern fringes of the North American Craton (Axtmann, 1983). Some of the ancient normal faults defining the original aulacogen became the site of uplift under the new stresses of the Pennsylvanian, and segments of the trough along the southern edge were uplifted to form the Wichita Mountains.

To the north of the Wichita Mountains, the crust was bowed down into a broad low, the Anadarko Basin (Figure 4.1), which extended from the Oklahoma panhandle into the northeast corner of Texas. In south-central Oklahoma, along the southeastern extension of the Anadarko Basin, shattered slivers of the aulacogen were squeezed and jumbled. This Arbuckle Orogeny was responsible for the major folds and faults observed in south-central Oklahoma (Ghazal, 1976). A series of narrow hills or islands was raised between a series of depressed, low blocks. Positive slivers, like the Hunton, Tishomingo and Criner Hills, and the Arbuckles were eroded. Coarse-grained debris from this erosion was washed into adjacent intervening depressions like the Ardmore and Marietta Basins (Figure 4.1). The basins across southern and western Oklahoma were filled by wedgeshaped sedimentary packages composed of conglomerates, sandstones, and shale. Over 25,000 feet of sediment, mostly derived from the Wichita Mountains, accumulated in the Anadarko Basin during Pennsylvanian time (Markas, 1966). Basin sediments were laid down in a wide variety of settings, including strandplains and barrier islands.

As Desmoinesian-age deposition began, tectonic activity was low around the Ardmore Basin. The Criner Hills had been worn down by that time, and a stable shallow-marine shelf environment had become established. The earliest sediments deposited in the Desmoinesian Series were the Lester, Frensley, and Pumpkin Creek Limestones (Johnson et al., 1988), separated by intervening shale units. Above the limestone and shale sequence is a complex mix of sediments classified as the Deese group (Figure 4.4). This group contains sandstones, shales, conglomerates (which include large numbers of limestone pebbles), cherts, and a few bedded limestones (Tomlinson and McBee, 1988).

In the Deese group, many beds thicken and thin rapidly making long-distance correlation difficult and unreliable. The Desmoinesian section is about 5,300 feet thick around the town of Deese (Tomlinson and $\mathrm{McBee}, 1988$ ) but increases to 8,000 feet toward the southeast. The Deese wedges included fluvial, deltaic, strandline, barrier island, and offshore environments at various locations within the basin. Some of the Deese units are rich in a variety of fossil types indicating the presence of both open-marine and shallow shoreline-associated environments in the area at various times. The source of most of the early Deese clastics was to the southeast, but by late Deese time, the primary source area had shifted to the Arbuckle region. Upper Deese units tend to cover larger areas including the site of the eroded Criner Hills and represent more widespread deposition of sands in the Ardmore Basin (Tomlinson and McBee, 1988).

During the Desmoinesian in the Anadarko Basin, deltas periodically prograded from northeast to southwest (GRI, 1993). Class 4 production is mainly from Lower Desmoinesian sands of the Deese-equivalent Cherokee group (Figure 4.4). 


\begin{tabular}{|c|c|c|c|}
\hline \multirow{2}{*}{$\sum_{\frac{1}{\omega}}^{\frac{5}{6}}$} & \multirow[b]{2}{*}{ SERIES } & \multicolumn{2}{|c|}{ GROUP } \\
\hline & & $\begin{array}{c}\text { ANADARKO } \\
\text { BASIN } \\
\text { s.\& sw. } \quad \text { w. \& cTR. }\end{array}$ & $\begin{array}{l}\text { ARDMORE } \\
\text { BASIN }\end{array}$ \\
\hline 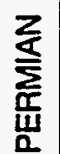 & WOLFCAMPIAN & $\begin{array}{c}\text { CHASE } \\
\text { COUNCIL GROVE } \\
\text { ADMIRE }\end{array}$ & PONTOTOC \\
\hline \multirow{5}{*}{ 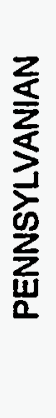 } & VIRGILIAN & 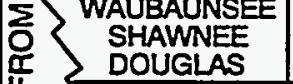 & \\
\hline & MISSOURIAN & 志 & HOXBAR \\
\hline & DESMOINESIAN & 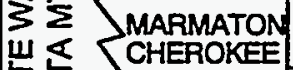 & DEESE \\
\hline & ATOKAN & 选高 & \multirow[t]{2}{*}{ DORNICK HILS } \\
\hline & MORROWAN & MORROW & \\
\hline \multirow{2}{*}{ 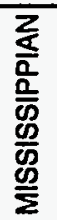 } & \multirow[b]{2}{*}{ CHESTERIAN } & SPRINGER & \multirow{2}{*}{ NOBLE RANCH } \\
\hline & & CHESTER & \\
\hline
\end{tabular}

\section{Figure 4.4 Stratigraphic Column for the Pennsylvanian of South-Central Oklahoma (Modified from: Johnson et al, 1988; GRI, 1993)}

\subsubsection{Reservoir and Play Characteristics}

The coast of the Desmoinesian sea was a high-energy region where wave action sorted and cleaned the sands. The best deposits for reservoir formation in the coastal sand complex are of the offshore barrier type where wave action is at a maximum. The wide range of depositional environments represented in the sediments resulted from shorelines that shifted back and forth over large areas repeatedly during the Pennsylvanian.

The major Pennsylvanian-age reservoirs in south-central Oklahoma produce from beds on structural highs within the Ardmore Basin. These highs were variously formed by Pennsylvanian or later folding, by drape over pre-existent structures, and by folding of sediments along active fault trends. Numerous large and small faults surround and cut through the Ardmore Basin. Movements were extensive on these faults during Pennsylvanian and post-Pennsylvanian time, and the resulting structures are complex.

Many of the traps in Desmoinesian intervals, especially those in the Anadarko Basin, have both structural and stratigraphic components. Some of the traps formed on the flanks of structures where porous strandplain/barrier island sands pinch out, or where they are truncated by faults. 


\subsubsection{Production Characteristics}

Production in Deese and Deese-equivalent intervals is widespread in south-central Oklahoma. Oil has been found throughout most of the Desmoinesian section. Desmoinesian Class 4 production comes from such fields as the Sho-Vel-Tum and Golden Trend, both of which produce from the Deese Group. The Sho-Vel-Tum field is listed in the TORIS database as having 1,072 million barrels of OOIP. The Golden Trend field, an assemblage of smaller fields, is listed as having 847 million barrels of OOIP. The Hewitt and Knox fields have smaller reserves, but are also large Desmoinesian producers. The Hewitt field had 591 million barrels of OOIP, and the Knox field had 157 million barrels of OOIP. These major production units are flanked by a number of smaller Desmoinesian oil fields with improved oil recovery potential.

Desmoinesian intervals in this play generally contain multiple sands, are steeply dipping, and often contain significant faulting. Wells are generally completed in several Pennsylvanian sand intervals. In most cases, fields also produce from several other intervals.

Production in some Desmoinesian Pennsylvanian fields in this play began in the early 1900 s. Most reservoirs produced by a combination of solution-gas drive, gravity drainage, and gas cap expansion during primary. Waterflood development began in the 1960s and continued through the 1970s. Most waterfloods simultaneously flood several intervals creating a flood-balancing challenge, because permeability varies between intervals. Channeling and early water breakthrough problems are prevalent, and waterflood recovery efficiencies are often low. These common waterflooding problems provided a strong incentive for early application of IOR techniques.

Recent advances in stratigraphic interpretation hold promise for future work in the south-central Oklahoma area. Studies of environments of deposition have made it possible to identify subtle permeability barriers within reservoirs, and to identify updip hydrocarbons that have not been previously tapped.

\subsubsection{Improved Oil Recovery Projects}

Historical IOR projects in the Southern Oklahoma Desmoinesian Play are listed in Table 4.4. Most activity has been in the Sho-Vel-Tum field (23 of 29 projects). In Sho-Vel-Tum, primary emphasis has been on polymer projects to remedy channeling problems experienced during waterflooding. Small in situ combustion and steam projects have been conducted in lower gravity $\left(14^{\circ}\right.$ to $16^{\circ} \mathrm{API}$ crude areas. Small $\mathrm{CO}_{2}$ and surfactant projects have also been conducted in the Deese interval.

\subsubsection{Polymer Projects}

All large projects have been polymer projects. Crude gravity in these projects ranges from $22^{\circ}$ to $35^{\circ}$ API. Mobil and Texaco are the operators of these large, 1980 s vintage projects. Production increases in Sho-Vel-Tum during the 1980s from these large polymer projects have previously been noted. 


\begin{tabular}{|c|c|c|c|c|c|c|c|c|}
\hline \multicolumn{9}{|c|}{$\begin{array}{l} \\
\text { N }\end{array}$} \\
\hline FIEID & RESERVOIR & OPERATOR & PROCESS & $\begin{array}{c}\text { DATE } \\
\text { STARTED }\end{array}$ & ACRES & $\begin{array}{l}\text { NO. OF } \\
\text { WELLS }\end{array}$ & $\begin{array}{l}\text { DEPTH, } \\
\text { FT }\end{array}$ & $\begin{array}{c}\text { GRAVIY, } \\
\text { API }\end{array}$ \\
\hline \multirow[t]{6}{*}{ HEWIIT } & HEWIT & EDRNGER & POLYMER & 1981 & 278 & 24 & 2,584 & 35 \\
\hline & HEWIT & EXXON & POLYMER & 1981 & 886 & 137 & 2,400 & 35 \\
\hline & HOXBAR & TEXACO & POLYMER & 1982 & 300 & 24 & 2,350 & 35 \\
\hline & HOXBAR & TEXACO & POLYMER & 1984 & 240 & 15 & 2,400 & 33 \\
\hline & LONE GROVE & IEXACO & POLYMER & 1984 & 1,200 & 96 & 4,500 & 35 \\
\hline & LONE GROVE & IEXACO & POLYMER & 1985 & 100 & 8 & 4,000 & 30 \\
\hline \multirow[t]{23}{*}{ SHO-VELTUM } & DEESE & $\operatorname{cox}$ & POLYAIER & 1979 & 10 & 4 & 3,172 & 24 \\
\hline & DEESE-TUSSY & $\operatorname{cox}$ & SURF. & 1980 & 10 & 9 & 3,172 & 24 \\
\hline & DEESE & MOBI & STEAM & 1986 & 55 & 14 & 1,500 & 16 \\
\hline & DEESE & MOBIL & POLYMIER & 1981 & & & & 35 \\
\hline & DEESESPPGR & MOBIL & POLYMER & 1982 & 1,360 & 123 & 4,400 & 30 \\
\hline & DEESE & MOBIL & POLYMER & 1982 & 780 & 64 & 3,500 & 30 \\
\hline & DEESE & MOBIL & POLYMER & 1982 & 350 & 31 & 4,000 & 31 \\
\hline & DEESE & MOBIL & POLYMER & 1982 & 451 & 36 & 3,900 & 34 \\
\hline & TATUMS-PENN & MOBIL & POLYMER & 1982 & 2,750 & 192 & 2,600 & 25 \\
\hline & DEESE & MOBL & POLYMER & 1982 & 450 & 35 & 3,500 & 28 \\
\hline & DEESE & MOBL & POLYMER & 1982 & 1,980 & 143 & 4,900 & 26 \\
\hline & DES MOIN. & SFEEIL & STEAM & 1964 & 80 & 19 & 850 & 14 \\
\hline & DEESE & SHEI & POLYMER & 1984 & & 34 & 3,200 & 28 \\
\hline & DEESE & SOHIO & POLYMER & 1985 & 120 & 5 & 4,640 & 38 \\
\hline & DEESE & TEXACO & $\mathrm{CO}_{2}$ & 1983 & & & 5,530 & 24 \\
\hline & DEESEHOXBAR & TEXACO & POLYMER & 1983 & 1,390 & 124 & 3,100 & 25 \\
\hline & DEESE & TEXACO & POLYMER & 1983 & 225 & 23 & 4,400 & 27 \\
\hline & HOXBAR & IEXACO & POLYMER & 1984 & 220 & 13 & 2,400 & 33 \\
\hline & DEESE & IEXACO & POLYMER & 1985 & 570 & 56 & 3,500 & 34 \\
\hline & TUSSY & TEXACO & POLYMER & 1986 & 1,128 & & 3,000 & 43 \\
\hline & DEESE & TEXACO & POLYMER & 1981 & 190 & 12 & 5,500 & 22 \\
\hline & DEESEHOXBAR & IEXACO & POLYMIER & 1983 & & 124 & 3,100 & 25 \\
\hline & DEESE & COX-MOBL & IN STIU & 1962 & 11 & 22 & 1,500 & 16 \\
\hline
\end{tabular}

Production in the Sho-Vel-Tum field comes from shallow Permian zones, the Deese, Hoxbar, and Dornick Hills-Springer groups in the Pennsylvanian interval, and the deeper Sycamore interval. Waterflood performance characteristics of these different intervals are summarized in Figure 4.5. Although the Dornick Hills-Springer group is of Pennsylvanian age, no Dornick Hills-Springer reservoirs are classified as Class 4 reservoirs in the TORIS database. Over $80 \%$ of water injection has been into the Class 4 Deese and Dornick Hills-Springer intervals. Waterflooding has been most efficient in the Dornick Hills-Springer interval recovering 35\% of the OOIP while requiring only 5 barrels of injection per barrel of oil recovered (Johnson et al., 1987a). Waterflood recovery in the Hoxbar and Deese intervals is much poorer, only $11 \%$ of the OOIP, requiring 12 to 14 barrels of injection per barrel of oil recovery.

Low waterflood efficiencies attributed to channeling and multiple-interval flooding prompted polymer applications in all intervals. Acreages under polymer flood for the Hoxbar, Deese, and Dornick Hills-Springer groups are 1,390, 11,300, and 5,100 acres, respectively (Johnson et al., 1987b). Locations of the Deese polymer projects are shown in Figure 4.6. 

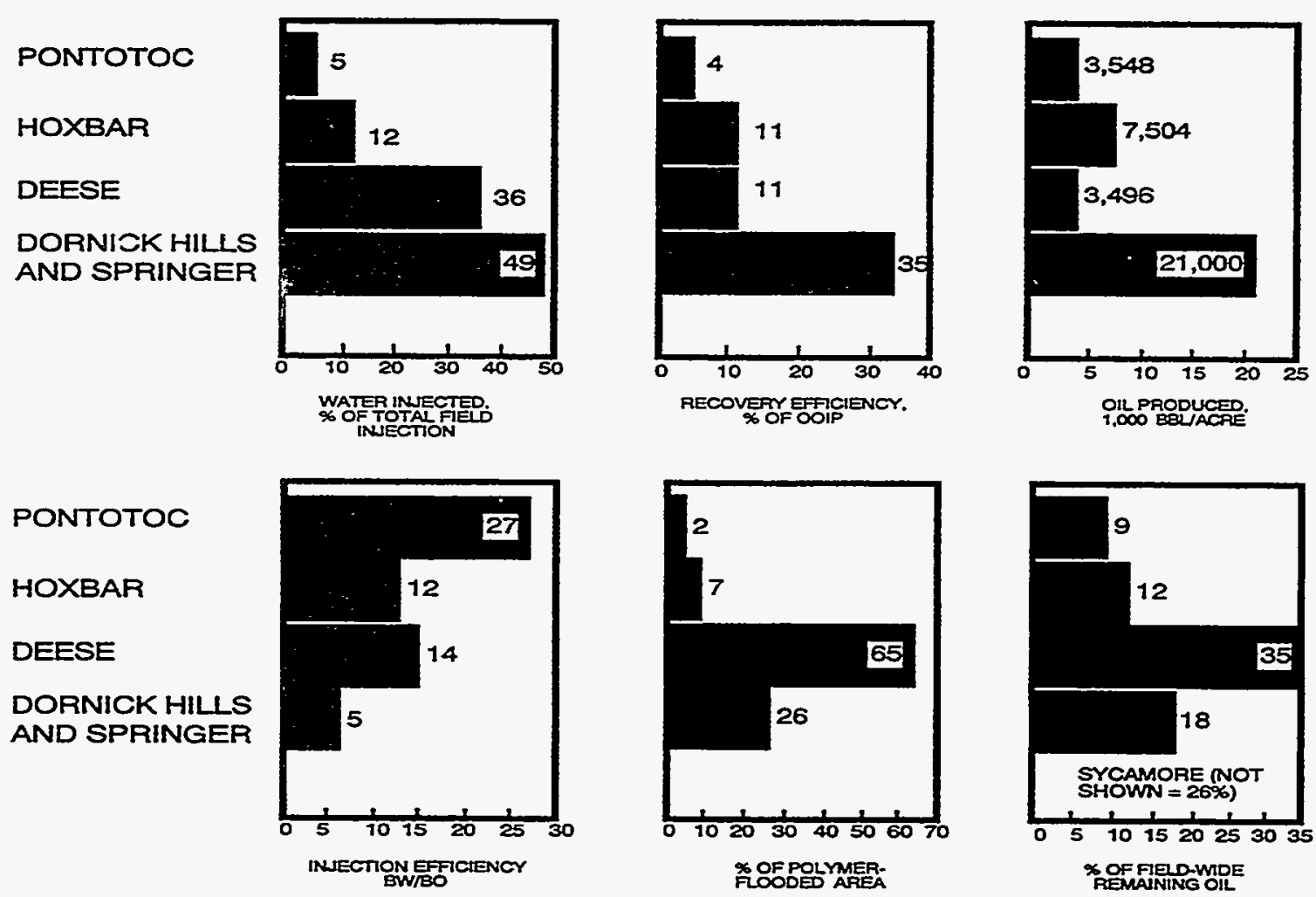

Figure 4.5 Waterflood Efficiencies in Selected Intervals of the Sho-Vel-Tum Field, Oklahoma (Modified after: Johnson et al., 1987a)

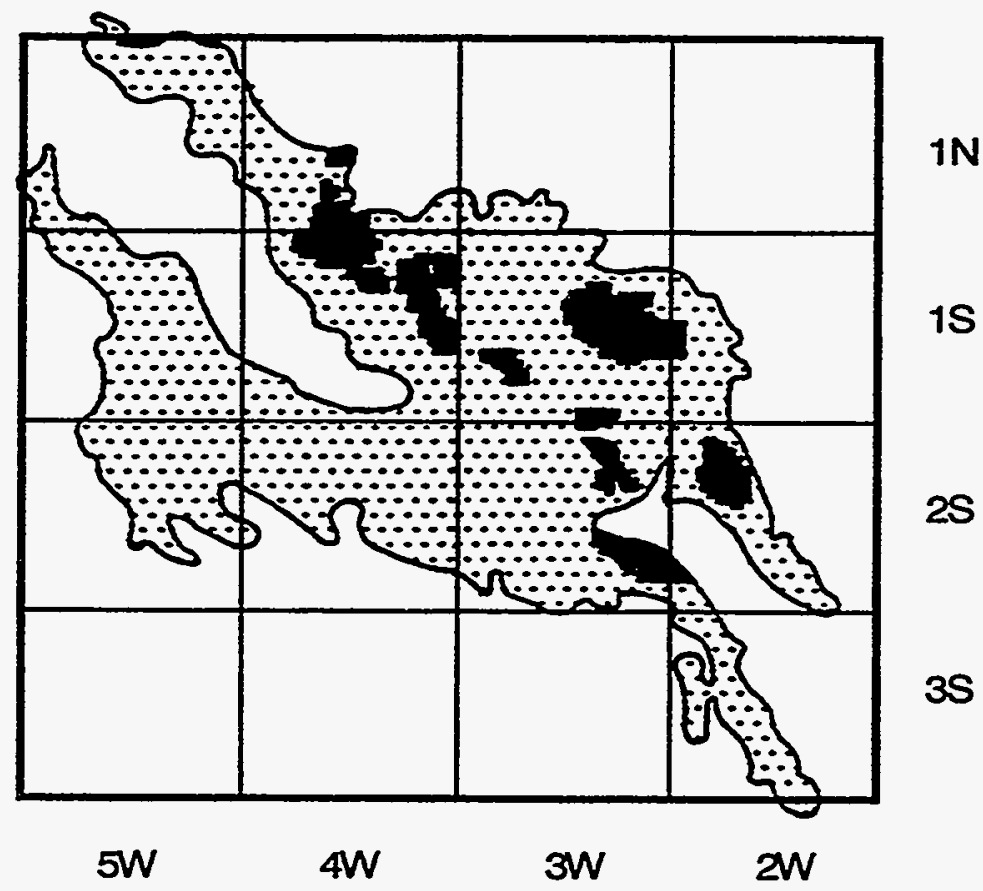

Figure 4.6 Location of Deese Interval Polymer Projects in the Sho-Vel-Tum Field, Oklahoma (Source: Johnson et al., 1987b) 


\subsubsection{Reservoir Management}

Besides polymer, advanced reservoir management techniques have been successfully used at Sho-Vel-Tum. Mobil applied 3-D seismic and integrated work-team concepts in their Countyline Unit, a 5 square mile waterflood (Kendall et al., 1992). The Countyline Unit was experiencing low waterflood recovery (only $11.2 \%$ of the OOIP) due to a combination of complex faulting, structural deformation, heterogeneity, and depleted gas caps. Application of these advanced reservoir management techniques caused Mobil to redefine the reservoir description leading to waterflood redesign and infill drilling. Results reported by Mobil include (1) several million barrels of added reserves, (2) ultimate recovery improved by $78 \%$, and (3) a new methodology to extend field life (Kendall et al., 1992). Mobil recognized the value of extending the concepts to other leases/units in the field.

Exxon experienced similar results with comprehensive reservoir management techniques in the flooded Hoxbar-Deese intervals in their Hewitt Unit in the Hewitt field (Ruble, 1982). Exxon reported reserve increases of 5 million barrels. Their reservoir management effort incorporated injection and production surveillance programs, injection distribution, producer stimulations, artificial lift optimization, infill drilling, and cross-linked polymer applications.

\subsubsection{Thermal Projects}

Thermal techniques have been applied in a small part of the field. In this area, heavy oil is found in the unconsolidated, steeply dipping, 4th Deese sand. Shell operated a small steamflood on its Hefner lease during the 1960s. At about the same time, Mobil started an in situ combustion project in a nearby unit, the Cox Penn Sand Unit. In the Shell steamflood, surface fissures with steam eruptions developed and the project was discontinued within a few years (Chiou and Murer, 1989). Mobil's in situ combustion project also lasted only a few years because problems in propagating the combustion front were experienced. Neither project was considered economic (Olsen and Johnson, 1993). A cyclic steam project started by Mobil in the same Unit in 1986 has been more economically encouraging (Moritis, 1992) even though numerous operating problems have been experienced (Chiou and Murer, 1989). Operating problems included oil treating, wellhead equipment failures, thermal well completions, artificial lift, and low steam injectivity.

Thermal projects in Sho-Vel-Tum are especially susceptible to environmental problems. The highly faulted and fractured nature of the area, poorly plugged wells, and age of existing wells contribute to aquifer or surface communication problems.

\subsection{Southern Oklahoma Bromide Play}

\subsubsection{Basin Development History}

As discussed in Section 4.2.1, southern Oklahoma Early Paleozoic geology was profoundly influenced by the presence of a Late Precambrian-Early Cambrian aulacogen (Figure 4.1). The Bromide formation was deposited during the Middle Ordovician Period as part of the Simpson Group. The Southern Oklahoma Aulacogen was still subsiding at an unusually high rate during the 
Ordovician Period. Although the southern margin of the craton was generally extremely stable and the water depths over broad areas (from the Northeastern U.S. to the Southwest) were relatively uniform and shallow (Johnson et al. 1988); the waters in southern and southwestern Oklahoma remained exceptionally deep, leading to the accumulation of thick Simpson sediments in that area. The eastern and northern ends of the basin were partially filled in during the period of Bromide deposition by periodic flooding with clastic sediments as the southern margin of the North American Craton warped or as sea level varied. Johnson et al. (1988) described the clastics as coming from "an eastern source." Frederickson et al. (1965) and Smith (1992) attribute the sediments to the Ozark area.

Simpson sediments, including the Bromide sandstones, are consistently recognizable over wide areas of the carbonate-rich shelf, and may include sand, silt, and fine clays eroded from an exposed landmass. Terrigenous clastics thicken to the east in Oklahoma, toward the presumed source area. In the Anadarko and Ardmore Basins, the Bromide is sandiest to the north and east. In the western portion of the Ardmore and Anadarko Basins, the Bromide is composed mainly of limestone or limy shales (GRI, 1993).

\subsubsection{Reservoir and Play Characteristics}

Reservoir models for the Bromide formation have traditionally considered the primary trapping mechanisms to be structure, often small, faulted anticlines (Smith, 1992; GRI, 1993). Reverse faults commonly underlie reservoirs in structural traps in the Anadarko and Admore Basins (GRI, 1993). Recent detailed studies have shown that a number of stratigraphic pinch-outs and internal permeability barriers are involved in many reservoirs, and in the segmenting of production into compartments within individual sand units. Smith (1992) specifically identified the following stratigraphic reservoir factors that affect Simpson/Bromide production: (1) interbedded low porosity/low permeability cementation barriers, (2) discontinuous sand lenses, (3) thin shale barriers, and (4) high porosity/high permeability zones. Some of the Bromide sands are described as structureless massive bodies indicating probable presence of high-energy beach ridge or eolian facies associated with either strandplain or barrier island deposits. Production comes from multiple sands, generally aligned along structural highs, capped by sealing Simpson Group shales.

Sand grains in the Simpson beds are generally well-rounded, indicating that they have been eroded, worn, deposited, and then re-eroded and reworked (Johnson et al., 1988; Frederickson et al., 1965). Bromide sediments are quite fossiliferous in many locations, with a broad variety of faunas. Skeletal limestone beds interspersed with sand units indicate deposition in clean, lowturbidity environments (Amsden and Sweet, 1983).

\subsubsection{Production Characteristics}

The Simpson Group has been a prolific producer of oil in south-central Oklahoma in the east part of the Anadarko and Ardmore Basins (GRI, 1993). The TORIS database shows that 444 million barrels of OOIP of the total Class 4 oil reserves within the Golden Trend are expected to come from Bromide rocks. The Eola-Robberson and Cumberland fields are also producing from the Bromide. Both have over 200 million barrels of OOIP. Cumulative oil production per field in 
the Bromide ranges from 36,000 to $12,000,000$ barrels (Smith, 1992). The predominant drive mechanism is pressure depletion and/or solution gas (GRI, 1993).

\subsubsection{Improved Oil Recovery Projects}

Current work in the Simpson Bromide involves infill drilling, the analysis of deep, untested, or incompletely studied structures, and limited IOR activity in existing fields.

The EOR project database (Pautz et al., 1992) shows only one project within this play, a Texacooperated polymer project in the Apache field. Polymer flooding of the 3,900 foot Bromide reservoir began in 1984 . Crude gravity is $39^{\circ} \mathrm{API}$ and viscosity is $2 \mathrm{cP}$. Porosity averages $13 \%$ and permeability is over $1,000 \mathrm{mD}$. The project involved 7 injection wells and 19 producers. Performance results are not available.

\subsection{Arkoma Morrowan Play}

\subsubsection{Basin Development History and Play Characteristics}

The cratonic edge in southeastern Oklahoma and central Arkansas had been a stable carbonate shelf during most of the early Paleozoic (Johnson et al., 1988). By Mississippian time, however, the Ouachita plate was impinging on the margin of the continent, and the stability was upset. The southern edge of the region was moving downward by combinations of flexure and normal faulting. An arcuate trough formed in the foreland area between the North American Craton and the adjacent Ouachita plate, and large amounts of coarse-grained sediment were dumped onto the subsiding shelf (i.e., the Arkoma Basin) as this activity began.

Coarse sediments were probably derived from areas to the south and/or east, possibly including island arc complexes off the continental edge. Sediment was also washing in from sources to the northeast. At the end of Mississippian time, the region rose above sea level and widespread erosion of the youngest Mississippian sediments took place (Figure 4.7).

By early Pennsylvanian (Morrow) time, seas again transgressed the shelf and significant amounts of sediment once again began to accumulate on the continental margin (Johnson et al., 1988). From late Mississipian through Morrowan, Atokan, and Desmoinesian time, clastics prograded basinward as deltas and barrier island complexes (Briggs, 1974). The Morrowan sediments appear to have had source areas to the north and northeast, in the region of the Illinois Basin and, possibly, around the Ozark area (GRI, 1993, Johnson et al., 1988). These sediments vary rapidly in thickness and texture across the region. There is a marked increase in percentage of limestone in the Morrow westward into Oklahoma and a corresponding decrease in the percentage of sandstone (Johnson et al., 1988).

Frequent shifting of the Morrow coastline caused a stacked series of strandline/barrier island sands to develop across the Arkoma Basin (GRI, 1993). Repeated advances and retreats of this strandline/barrier island complex resulted in widespread deposition of reservoir-quality sandstones separated by thin shales. 


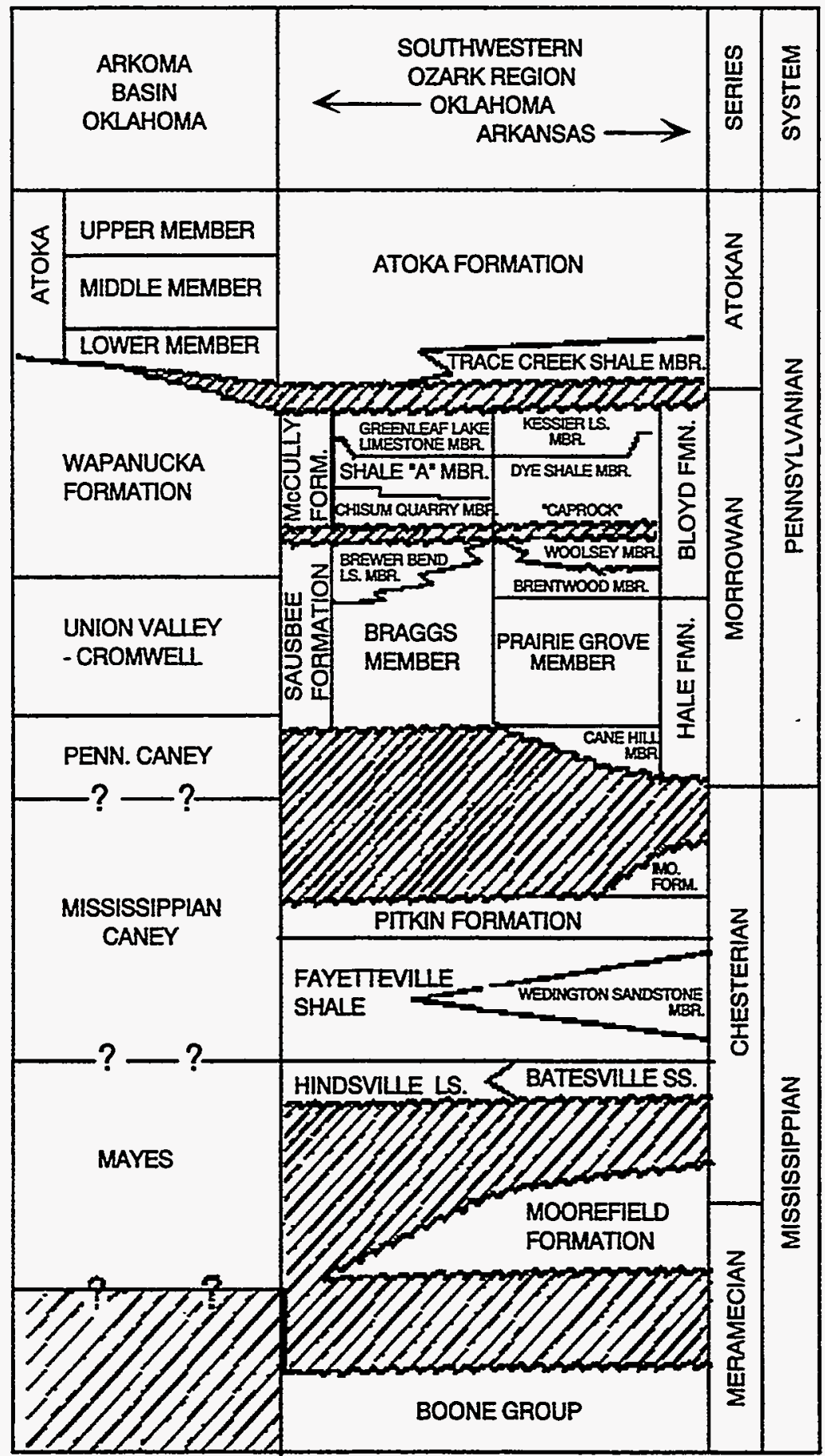

Figure 4.7 Stratigraphic Correlation Chart for Upper Mississippian and Lower Pennsylvanian Formations and Members in the Arkoma Basin (modified from: Johnson et al., 1988) 


\subsubsection{Reservoir and Production Characteristics}

Arkoma Basin oil production is limited to the western end of the structural basin. The eastern and central portions of the basin yield large quantities of natural gas, but very little oil. The predominance of natural gas appears to relate to tectonic activity, depth of burial, and geothermal gradients across the region.

The TORIS database lists three Class 4 oil reservoirs located in the Oklahoma portion of the Arkoma Basin having OOIP volumes in excess of 200 million barrels. The fields are the Cromwell (263 million barrels), the Wewoka District (262 million barrels), and the largest, the Allen District (457 million barrels). The Little River field has more limited reserves (155 million barrels).

Oklahoma Morrowan reservoirs in the Arkoma Basin produce mainly from combination stratigraphic/structural traps. Faulted anticlines are the dominant traps in the Arkansas part of the Basin (GRI, 1993).

The dominant drive mechanisms reported for reservoirs in this play are pressure depletion and/or water drive.

\subsubsection{Improved Oil Recovery Projects}

The EOR project database (Pautz et al., 1992) shows only one Class 4 project within this play, a 215-acre Mobil-operated polymer project in the Fitts field. Polymer flooding of the Cromwell, Viola, and Hunton reservoirs began in 1981 . Crude gravity is $40^{\circ} \mathrm{API}$ and viscosity is $2 \mathrm{cP}$. Depth is about 2,500 feet. Mobil reported permeability up to $1,500 \mathrm{mD}$ and an initial oil saturation of 77\%. Performance results are not available.

\subsection{IOR Activity in Other Oklahoma Class 4 Plays}

\subsubsection{Southern Oklahoma Missourian Play}

Polymer and steam projects have been conducted in the Southern Oklahoma Missourian (Pennsylvanian) Play. The Healdton field has been the site of significant polymer flooding activity. Arco, Mobil, and Unocal each conducted relatively large polymer projects (Pautz et al., 1992). Primary and secondary production characteristics in the Healdton field parallel those in the ShoVel-Tum field.

Conoco has conducted two steam pilots in the Pennsylvanian sand in the Loco field. Oil gravity in these steam projects was in the $20^{\circ}$ to $22^{\circ}$ API range. Projected recoveries at project start were $38 \%$ and $52 \%$ of OIP with steam/oil ratios of 5.7 and 4.2, respectively (Powers et al., 1985). Despite promising results, these projects have not been expanded to commercial-size.

\subsubsection{Southeast Anadarko Morrowan Play}

Only minor IOR activity has occurred in the Anadarko Basin. Polymer projects have been reported in the Pennsylvanian Morrow sand in the Postle field (Pautz et al., 1992). Mobil began 
considering IOR activity in this field in the early 1970s. At that time, low-tension waterflooding was considered (Roy et al., 1977). In preparing for tertiary recovery, Mobil conducted a relatively extensive reservoir management program. Mobil applied polymers in lieu of the originally planned low-tension waterflood. Later on in 1990, Mobil considered applying the $\mathrm{CO}_{2}$ miscible process in the Postle field (Moritis, 1990). A CO 2 project was not listed for the Postle field in the 1992 Oil and Gas Journal Survey (Moritis, 1992).

\subsection{References}

Amsden, T.W. and W.C. Sweet, 1983, Upper Bromide formation and Viola group (Middle and Lower Ordovician) in Eastern Oklahoma: Oklahoma Geological Survey Bulletin 132, 76 p.

Axtmann, T.C., 1983, Structural mechanisms and oil accumulation along the Mountain View-Wayne Fault, south-central Oklahoma, Part 1: The Shale Shaker, vol. 34, No. 1, September, p. 1-12.

Briggs, G., 1974, Carboniferous depositional environments in the Ouachita Mountains-Arkoma Basin area of southeastern Oklahoma: Geological Society of America, Special Paper No. 148, p. 225-239.

Chiou, R.C.S. and T.S. Murer, 1989, Cyclic steam pilot in gravity drainage reservoir: SPE 19659 64th Annual Technical Conference, San Antonio, Texas, p. 319-332.

Frederickson, E.A., R.H. Redman, and J.M. Westheimer, 1965, Geology and petroleum of Love County, Oklahoma: Oklahoma Geological Survey Circular 63, 92 p.

Ghazal, R.L., 1976, Structural analysis and mapping of the western part of the Caddo Anticline, Carter County, Oklahoma, Part 1: The Shale Shaker, vol. 27, No. 7, p. 126-137.

GRI (Gas Research Institute), 1993, Atlas of major midcontinent gas reservoirs: D.G. Bebout, W.A. White, T.F. Hentz, and M.K. Grasmick (editors), 85 p.

Haiduk, J., 1990, Facies analysis, paleoenvironmental interpretation, and diagenetic history of Britt sandstone (Upper Mississippian) in portions of Caddo and Canadian Counties, Oklahoma: Shale Shaker, vol. 40, No. 5, March-April, p. 118-136.

Johnson, K.S., T.W. Amsden, R.E. Denison, S.P. Dutton, A.G. Goldstein, B. Rascoe, Jr., P.K. Sutherland, and D.M. Thompson, 1988, Southern midcontinent region: in L.L. Sloss, ed., The Geology of North America, Volume D-2, Sedimentary Cover - North American Craton: U.S.: The Geological Society of North America, p. 307-359.

Johnson, H.R., K. Biglarbigi, L.K. Schmidt, R.M. Ray, and S.C. Kyser, 1987a, Reservoir/fluid characteristics favor enormous long-term recovery potential: Oil and Gas Journal, vol. 85, No. 3, January 19 , p. 38-43.

Johnson, H.R., K. Biglarbigi, L.K. Schmidt, R.M. Ray, and S.C. Kyser, 1987b, Primary and secondary recovery in the Sho-Vel-Tum oilfield, Oklahoma: Department of Energy Report DOE/ $\mathrm{BC} / 14000-1$, October, $26 \mathrm{p}$.

Kendall, J., G. Killberg, L. Zambrano, and J.E. Valusek, 1992, New technologies aid multidisciplinary success in 80-year-old field: Petroleum Engineer International, vol. 64, No. 12, December, p. 14-18. 
Markas, J.M., 1966, Subsurface geology of northern McClain County, Oklahoma: Shale Shaker, vol. 16, No. 9, May, p. 198-213.

Moritis, G., 1990, $\mathrm{CO}_{2}$ and $\mathrm{HC}$ injection lead EOR production increase: Oil and Gas Journal, vol. 88, No. 17, April 23, p. 49-82.

Moritis, G., 1992, EOR increases $24 \%$ worldwide; claims $10 \%$ of U.S. production: Oil and Gas Journal, vol. 90, No. 16, April 20, p. 51-79.

Olsen, D.K. and W.I. Johnson, 1993, Feasibility study of heavy oil recovery in the Midcontinent region (Kansas, Missouri, Oklahoma): Department of Energy Report NIPER-560/DE93000165, August, 168 p.

Pautz, J.F., C.A. Sellers, C. Nautiyal, and E. Allison, 1992, Enhanced oil recovery projects data base: Department of Energy Report NIPER-583, February, 344 p. plus Appendix D.

Powers, M.L., C.J. Dodson, F. Ghassemi, and J.S. Moore, 1985, Commercial application of steamflooding in an oilfield comprising multiple thin sand reservoirs: Journal of Petroleum Technology, vol. 37, No. 9, September, p. 1707-1715.

Roy, M.B., C.W. Tucker, C.J. Lakey, and W.B. Cloud, 1977, Waterflood redevelopment prior to future tertiary attempts-a case history: SPE 6460 Oklahoma City Regional Meeting on Operating Practices in Drilling and Production, Oklahoma City, Oklahoma, 12 p.

Ruble, D.B., 1982, Case study of a multiple sand waterflood, Hewitt Unit, OK: Journal of Petroleum Technology, vol. 34, No. 3, March, p. 621-627.

Smith, P.W., 1992, Factors controlling Simpson Group production in central Oklahoma, Part 1: The Shale Shaker, vol. 34, No. 2, January/February, p. 12-26.

Sutherland, P.K, 1988, Late Mississippian and Pennsylvanian depositional history in the Arkoma Basin area, Oklahoma and Arkansas: Geological Society of America Bulletin, vol. 100, No. 11, November, p. 1787-1802.

Tomlinson, C.W. and W. McBee, Jr., 1988, Pennsylvanian sediments and orogenies of Ardmore District, Oklahoma: in Petroleum Geology of the Mid-Continent, Tulsa Geological Society, Special Publication No. 3, p. 85-89. 


\section{CHAPTER 5 MAJOR CALIFORNIA STRANDPLAIN/BARRIER ISLAND PLAYS}

The strandplain/barrier island reservoirs in California represent a significant portion of the Class 4 resource in the country, as defined in the DOE Tertiary Oil Recovery Information System (TORIS). Most of the Class 4 resource in Califormia is found in three plays: the San Ardo-King City Shelf Sandstone in the Salinas Basin; the Vaqueros Strandplain Sand in the Cuyama Basin; and the Vedder/Pyramid Hills Strandplain Sandstone in the San Joaquin Valley. This chapter describes the geologic characteristics of these three distinct plays relative to the trapping and production of hydrocarbons. The characteristics of the numerous other strandplain/barrier island plays in California are not described in this chapter.

The reservoir and production characteristics of the California Class 4 plays are summarized in this chapter based on an analysis of over 50 reservoirs contained in the TORIS database and a review of the technical literature. This analysis indicates that reservoirs in these plays have excellent reservoir quality and tend to contain heavy oil. Based on literature review, the improved recovery process which has been most widely utilized in the California Class 4 reservoirs is steam injection. Although other improved recovery processes may be applicable in California, most of the future recovery potential depends on maintaining the profitability of steam flood operations through the reduction of operating costs and improvements in process efficiency. The requirements associated with meeting increasingly stringent environmental restrictions also pose a significant challenge to future operations.

\subsection{Overview of California Plays and Basin Development History}

California is a major contributor to oil production from Class 4 reservoirs. Class 4 reservoirs in California contain 3.4 billion barrels of remaining oil-in-place (ROIP), representing approximately $18 \%$ of the ROIP for Class 4 reservoirs identified in the TORIS database (Table 5.1). Cumulative recovery of 1.3 billion barrels is $28 \%$ of the OOIP. Estimated remaining reserves with current operations are only 47 million barrels. Approximately $78 \%$ of the ROIP in California Class 4 reservoirs is contained in three major plays: the San Ardo-King City Shelf Sandstone, the Vaqueros Strandplain Sands, and the Vedder/Pyramid Hills Strandplain Sandstone Plays.

Three major elements dominate the early Tertiary-aged paleogeography of California (Nilsen, 1984) and control subsequent development of most California Tertiary basins. Each of these elements evolved from a Cretaceous trench, forearc basin, and magmatic arc framework (Nilsen and Clarke, 1975; Clark et al., 1975; Nilsen, 1977; Nilsen and McKee, 1979). Highlands in the eastern part of the state underlain by Mesozoic granitic plutons constitute the first major element. The second major element is the elongate and broad Sacramento-San Joaquin Basin which developed on the old forearc basin. It was a shallow marine shelf bounded by a coastal plain to the east and by a deep basin on the west. Persistent arches (e.g., the Stockton and Bakersfield Arches) tended to subdivide the basin. The third element, a borderland terrain to the west, consists of a series of uplands, often islands, separated by subsiding, deep, and often partly restricted basins receiving 


\begin{tabular}{|c|c|c|c|c|}
\hline \multicolumn{5}{|c|}{ 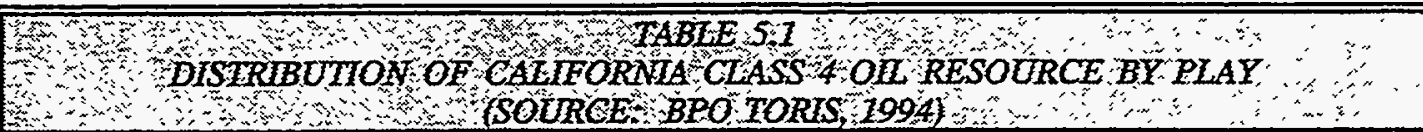 } \\
\hline PLAY & $\begin{array}{l}\text { ORIGINAL } \\
\text { OIL-IN-PLACE } \\
\text { MMBO }\end{array}$ & $\begin{array}{l}\text { CUMULATTVE } \\
\text { RECOVERY } \\
\text { MMBO }\end{array}$ & $\begin{array}{l}\text { REMAINING } \\
\text { OIL-IN-PLACE } \\
\text { MMBBO }\end{array}$ & $\begin{array}{c}\text { NUMBER } \\
\text { OF RESERVOIRS }\end{array}$ \\
\hline SAN ARDO-KING CITY SHELF SS & 1,509 & 407 & 1,090 & 2 \\
\hline $\begin{array}{l}\text { VAQUEROS (PAINTED ROCKS) } \\
\text { STRANDPLAIN SANDS }\end{array}$ & 1,045 & 268 & 777 & 2 \\
\hline $\begin{array}{l}\text { VEDDER/PYRAMID HIIIIS } \\
\text { STRANDPLAIN SS }\end{array}$ & 1,204 & 440 & 735 & 8 \\
\hline SUBTOTAL LARGEST PLAYS & 3,758 & 1,116 & 2,602 & 12 \\
\hline PICO TURBIDITE SS & 314 & 47 & 266 & 1 \\
\hline $\begin{array}{l}\text { SANTA MARGARTTA } \\
\text { STRANDPLAN/DELTAIC SAND }\end{array}$ & 202 & 48 & 152 & 5 \\
\hline $\begin{array}{l}\text { VAQUEROS/ALGERIA } \\
\text { STRANDPLAIN }\end{array}$ & 204 & 64 & 139 & 4 \\
\hline $\begin{array}{l}\text { SAN JOAQUIN/KERN } \\
\text { RIVERDELTAIC/LACUSTRINE }\end{array}$ & 83 & 7 & 76 & 2 \\
\hline $\begin{array}{l}\text { OLCESE/ZILCH } \\
\text { FLUVIALALLUVIAL SS }\end{array}$ & 50 & 7 & 43 & 1 \\
\hline TEMBLOR DELTAIC/SHEIF SS & 48 & 8 & 39 & 2 \\
\hline LLAJAS STRANDPLAIN SS & 39 & 2 & 37 & 1 \\
\hline NON-DEFINED & 46 & 14 & 31 & 1 \\
\hline SISQUOC SHELF SS & 29 & 8 & 21 & 1 \\
\hline PICO STRANDPLAIN/DELTAIC SS & 18 & 3 & 15 & 1 \\
\hline $\begin{array}{l}\text { SUBTOTAL OTHER } \\
\text { CAIIFORNIA PLAYS }\end{array}$ & 1,032 & 207 & 819 & 19 \\
\hline TOTAL CALIFORNIA PLAYS & 4,790 & 1,322 & 3,421 & 31 \\
\hline
\end{tabular}

thick accumulations of turbidite sediments. Tectonism was the chief controlling factor on sedimentation in most California sedimentary basins during the Tertiary.

Deposition of strandplain/barrier island sediments took place on the shallow shelves adjoining rapidly subsiding Tertiary basins. Sediments contributing to these deposits came from coastal plain sources to the east, and in some cases, from the borderland terrain to the west.

Well-developed strandplain/barrier island deposits in the Salinas Basin are in Middle and Upper Miocene Lombardi, Aurignac, and Thorup sands of the Monterey formation. In the Cuyama Basin, similar deposits occur in the Oligocene- to Miocene-age Vaqueros formation. The San Joaquin Basin also has a prominent strandplain/barrier island play in the Oligocene- to Mioceneage Vedder, Jewett, and Pyramid Hills sands.

The ROIP volumes and other reservoir parameters for the three major plays and all other Class 4 California plays are averaged and summarized in Table 5.2. California Class 4 reservoirs produce medium to mainly heavy oil from thick formations having an average net pay of 132 feet. These reservoirs are located at an average depth of 3,000 feet, have an average porosity of $30 \%$, average permeability above $1,600 \mathrm{mD}$, and an initial oil saturation slightly below $70 \%$.

Estimated ultimate recovery efficiencies with current operations for the San Ardo-King City, Vaqueros, and Vedder/Pyramid Hills Plays are 33, 26, and 36\% of the OOIP respectively. Production in California's Class 4 reservoirs is dominated by major producers, as shown in Figure 5.1. 


\begin{tabular}{|c|c|c|c|c|c|}
\hline \multirow{2}{*}{\multicolumn{6}{|c|}{ 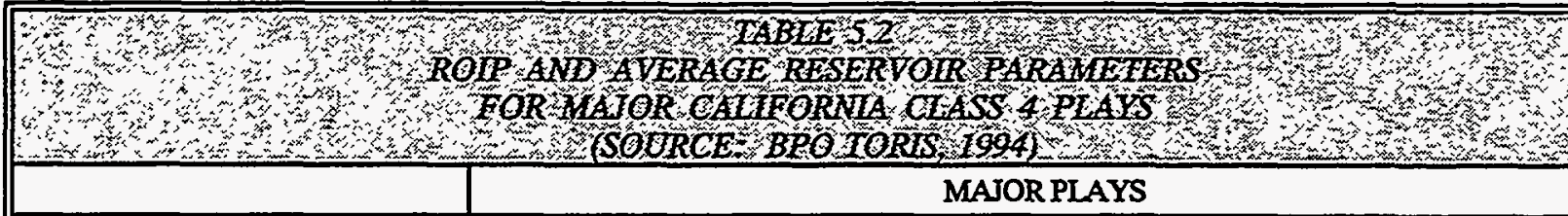 }} \\
\hline & & & & & \\
\hline 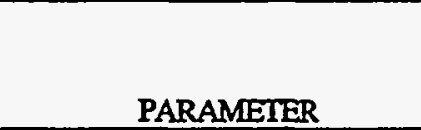 & $\begin{array}{c}\text { SAN ARDO-KING } \\
\text { CITY } \\
\text { SHEIIFSS }\end{array}$ & $\begin{array}{l}\text { VAQUERROS } \\
\text { STRANDPLAIN } \\
\text { SANDS }\end{array}$ & $\begin{array}{l}\text { VEDDER/ } \\
\text { PYRAMII } \\
\text { HIIIS }\end{array}$ & $\begin{array}{c}\text { OTHERS } \\
\text { CALIFORNIA } \\
\text { PLAYS }\end{array}$ & $\begin{array}{l}\text { OVERALL } \\
\text { AVERAGE } \\
\text { VALUES }\end{array}$ \\
\hline $\begin{array}{l}\text { REMAINING OIL-IN-PLACE, } \\
\text { MMBO }\end{array}$ & 1,090 & 777 & 735 & 819 & \\
\hline NET PAY,FT & 117 & 215 & 61 & 138 & 132 \\
\hline POROSITY, \% & 34 & 26 & 31 & 28 & 30 \\
\hline INIIIAL OIL SATURATION, \% & 73 & 69 & 70 & 65 & 69 \\
\hline DEPTH, FT & 2,236 & 3,500 & 3,552 & 2,652 & 2,985 \\
\hline PERMEABLITY,mD & 3,600 & 169 & 1,654 & 1,124 & 1,637 \\
\hline GRAVITY, ${ }^{\circ} \mathrm{API}$ & 12 & 32 & 22 & 21 & 22 \\
\hline INITIAL PRESSURE, PSI & 971 & 1,466 & 1,313 & 1,183 & 1,233 \\
\hline ULTIMATE RECOVERY, \% & 33 & 26 & 36 & 23 & 29 \\
\hline
\end{tabular}

The production data from 1991 indicate that $82 \%$ of the 1991 production volume was produced by majors, followed by $18 \%$ by small independents.

Annual production volumes since 1970 for the three major plays are illustrated in Figure 5.2. The production curves illustrate the increase in heavy oil production between 1971 and 1977 in the San Ardo-King City Play, which is a reflection of improved oil recovery (IOR) activities. Similarly, there is a sharp increase in the daily oil production rate, primarily heavy oil, in the Vedder/ Pyramid Hills Play after 1976 reflecting major IOR activities. In contrast, the Vaqueros Strandplain Play showed a steep decline in oil production which is consistent with limited or no IOR activity.

Historically, steam injection is the major IOR process used in the California plays. Four projects were conducted in the San Ardo-King City Play, followed by three projects in the reservoirs of the Vedder/Pyramid Hills Play. Table 5.3 summarizes production from the steam projects by play based on the 1992 Oil and Gas Journal IOR Survey (Moritis, 1992).

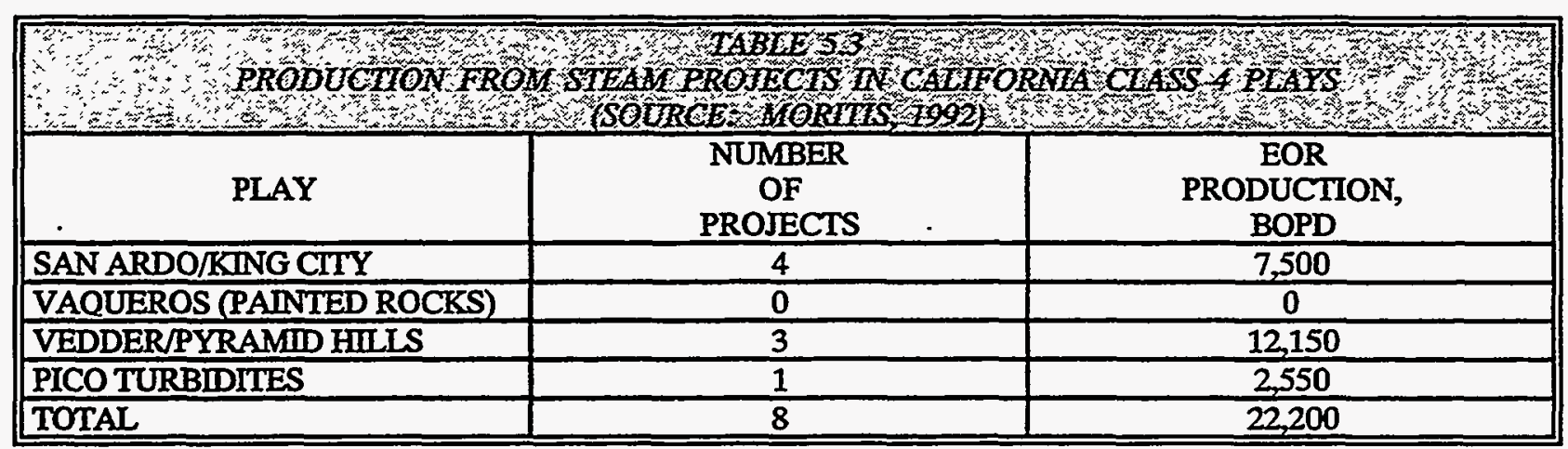


SMALL INDEPENDENTS

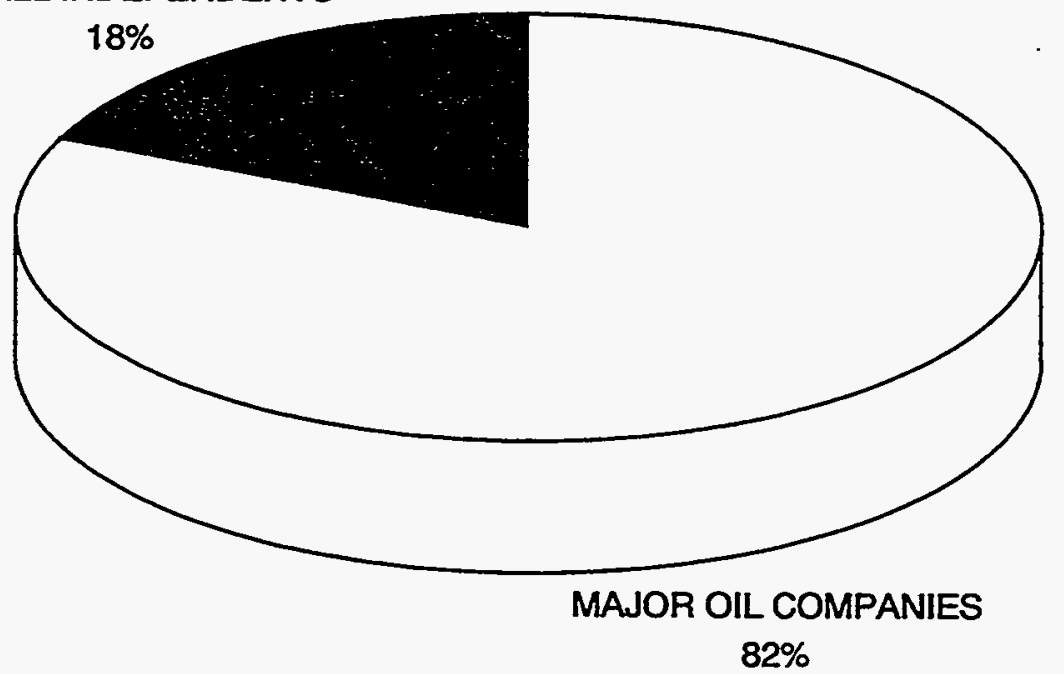

Figure 5.1 Operator Profile for California Class 4 Reservoirs (Source: BPO TORIS, 1994)

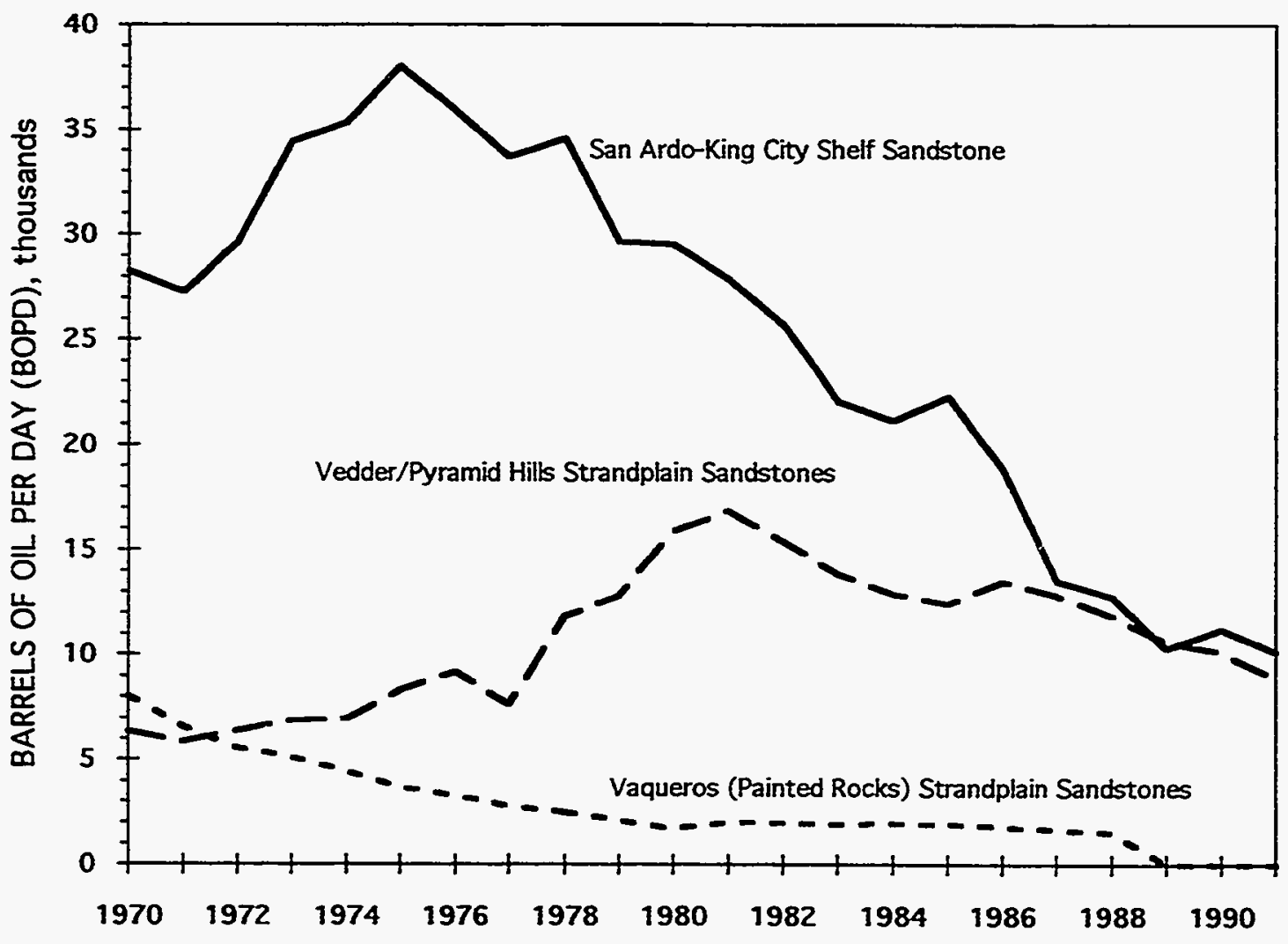

Figure 5.2 Historical Production for Major California Class 4 Plays (Source: BPO TORIS, 1994) 


\subsection{San Ardo - King City Play, Salinas Basin, California}

\subsubsection{Play Description}

The San Ardo-King City Play in the Salinas Basin (Figure 5.3) of southern California has several fields which produce from strandplain/barrier island deposits. San Ardo field, vastly larger than the rest, produces from the Lombardi and the Aurignac sands (Figure 5.4) of the Upper Miocene Monterey formation. Other much smaller fields nearby (e.g., Lynch Canyon field, Lombardi Pool, Paris Valley field) produce from reservoirs similar in age to the San Ardo field, while the King City field to the northwest produces from Middle Miocene sands of the Monterey (Figure 5.5).
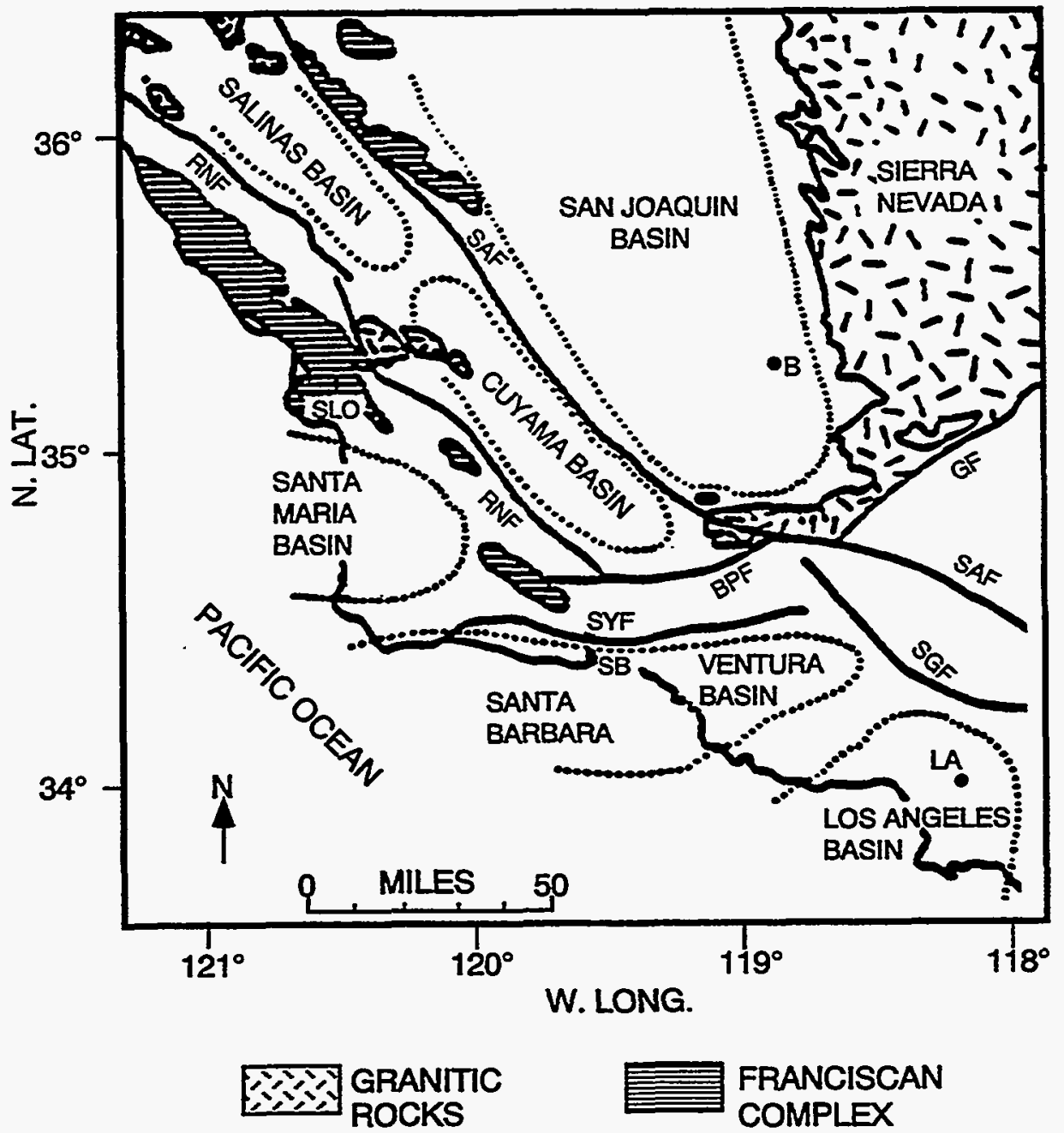

Figure 5.3 Major Basins in West Central California-Faults: R-NF, Rinconada-Nacimiento Fault; SAF, San Andreas Fault; BPF, Big Pine Fault; SYF, Santa Ynez Fault; SGF, San Gabriel Fault, GF, Garlock Fault. Cities: B, Bakersfield; SLO, San Luis Obispo; SB, Santa Barbara; LA, Los Angeles, (Modified from: Lagoe, 1984, reprinted by permission) 


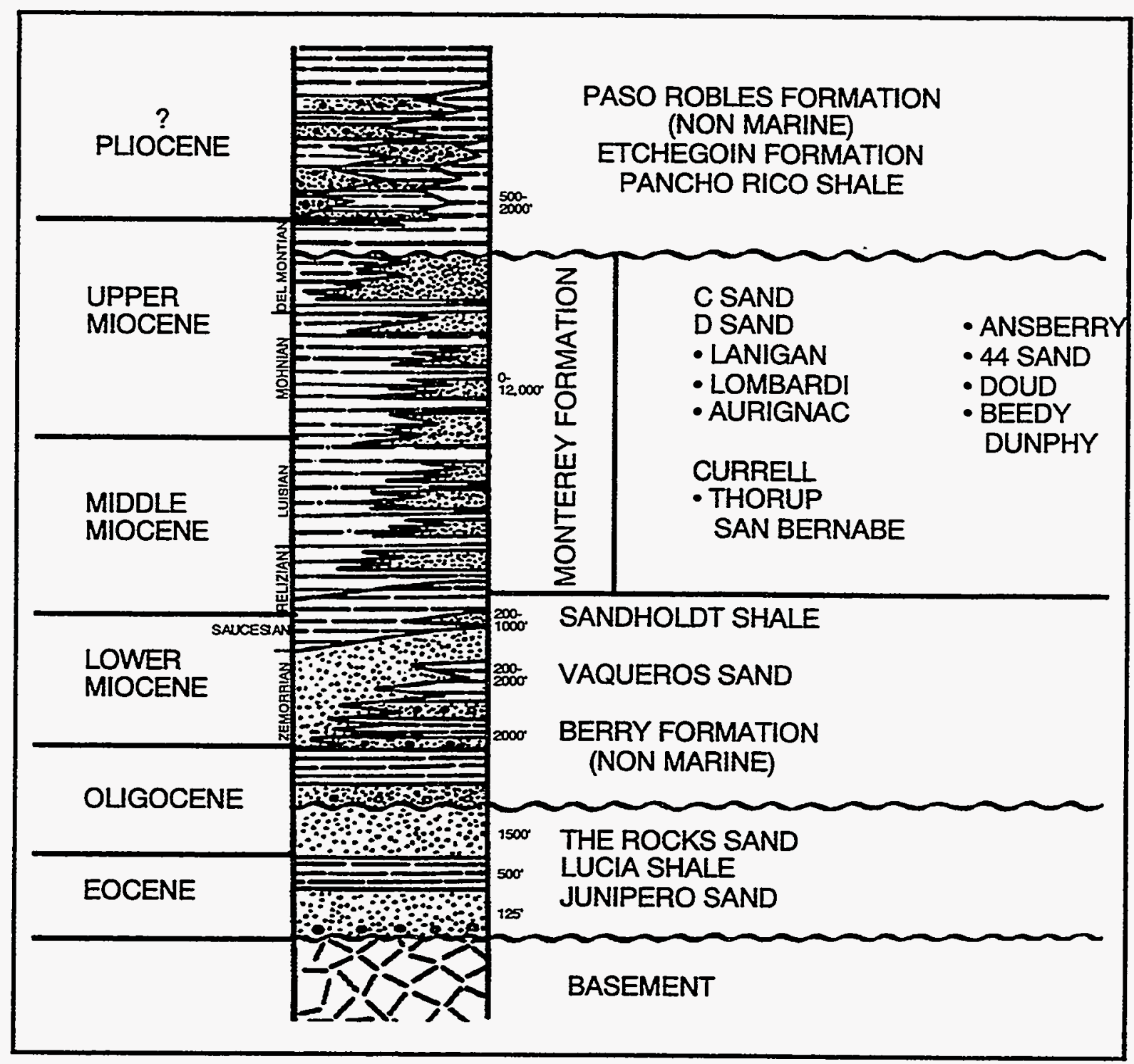

Figure 5.4 Stratigraphic Column for the California Class 4 San ArdoKing City Play (Modified from: Gribi, 1963) 


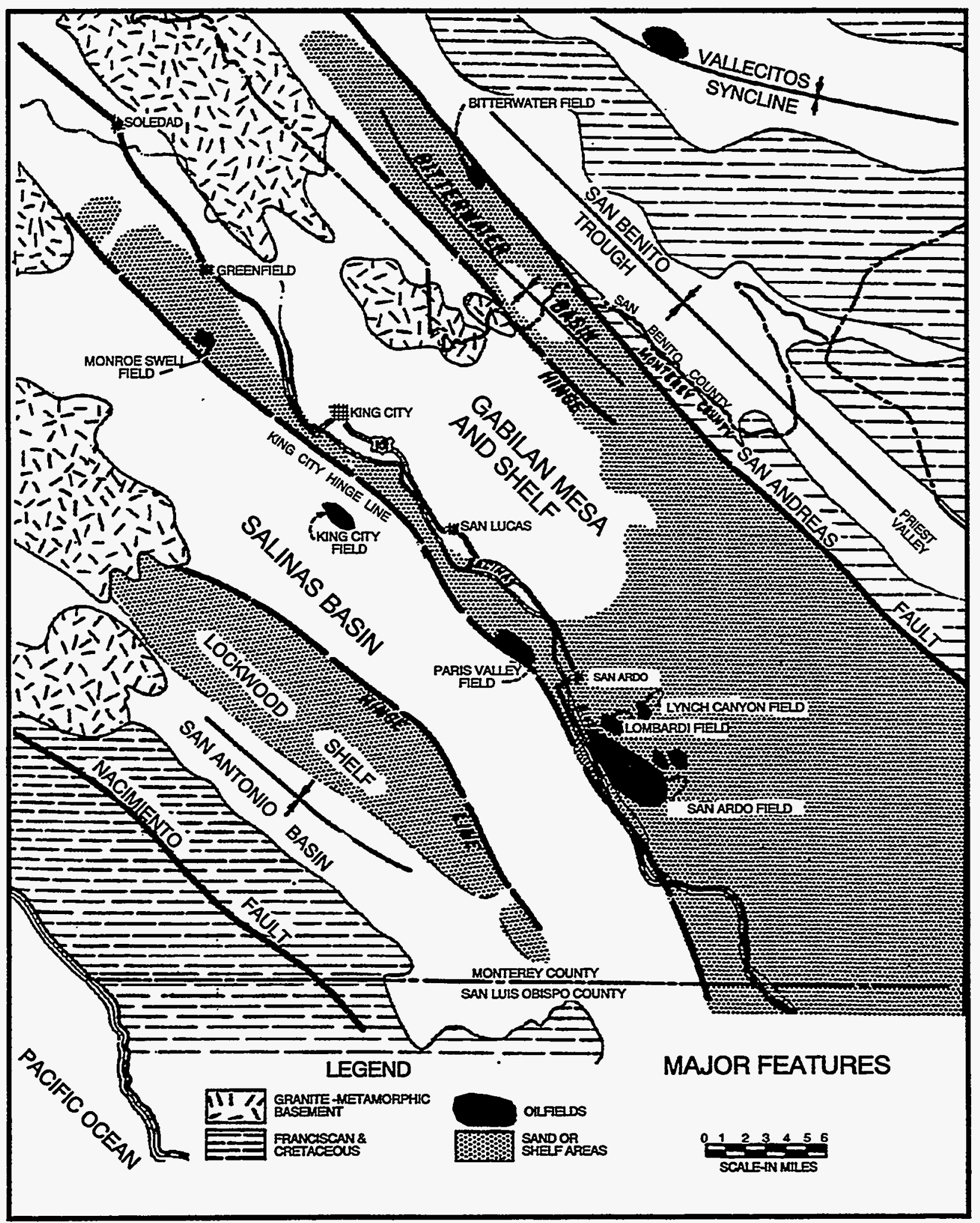

Figure 5.5 Structural Features Associated with California Class 4 Reservoirs of the SanArdo-King City Play (Modified from: Gribi, 1963) 
The Salinas Basin is a structural trough and Miocene sedimentary basin lying between the Salinas River on the northeast and the Lockwood Valley on the southwest. The basin is about 45 miles long, averages 6 miles wide, and contains up to 15,000 feet of marine sediments at its deepest point (Gribi, 1963). Up to 3,000 feet of Middle Miocene sediments were deposited with only small variation in intraformational thickness throughout the basin. On the east side of the basin, sediments lap onto non-marine or basement rocks. Strandplain/barrier island sands are developed along this depositional edge. Most sands exhibit a transgressive architecture overall, but according to Gribi (1963), in the King City field area, up to 1,500 feet of sand are interbedded in the Middle Miocene section. During deposition of the Upper Miocene, up to 8,000 feet of shales were deposited in the basin center, but the section thins rapidly shoreward. Again, strandplain/barrier island sands in a transgressive architecture were deposited on the eastern shelf of the basin. Individual sand bodies range from 30 to 200 feet in thickness and are traceable for up to 15 miles along strike (Gribi, 1963). After deposition of the potential reservoir sands, movement along basement faults caused development of a linear feature-the King City Hinge Line on Figure 5.5-separating the shelf from the deep basin. Organic shales of the deeply buried Monterey in the basin center are the likely source for hydrocarbons trapped in these strandplain/barrier island reservoirs.

\subsubsection{Reservoir Characteristics, Models, and Major Controls on Production}

San Ardo field produces from two Upper Miocene strandplain/barrier island sands, the Lombardi sand and the Aurignac sand (Figure 5.4 and Figure 5.6). In these reservoirs, as in other Upper Miocene reservoirs in the basin, sands are very coarse and well-sorted with permeabilities averaging 4 Darcies in the Lombardi, 1 Darcy in the Aurignac, and porosities in both about 30\% (Miller, 1953). At San Ardo field, oil is stratigraphically trapped against the seaward edge of distal bar facies sands on the western edge of the deposit, toward the King City Hinge Line (Figure 5.5 and Figure 5.6). Uplift on vertical faults at the end of Santa Margarita deposition led to doming along the shelf edge and subsequent removal of up to 150 feet of reservoir rock at San Ardo field.

The King City field produces from the Middle Miocene Thorup sand, a well-cemented sand with permeabilities in the 0.5 to 2 Darcy range (Figure 5.4). In this reservoir, oil is also stratigraphically trapped by updip pinch-out toward the King City Hinge Line, but in this instance, against the landward edge of the strandplain/barrier island sand development. Post-Monterey vertical tectonic movements have complicated the structure of the King City field.

\subsubsection{Production Characteristics}

Within the major California strandplain/barrier island plays, the San Ardo-King City Play has the highest estimated ROIP at approximately 1.1 billion barrels of heavy oil. The OOIP is estimated at 1.5 billion barrels, as reported in the TORIS database, of which $27 \%$ has been recovered.

The reservoirs of the San Ardo-King City Play are characterized by heavy crude with average oil gravity of $12^{\circ}$ API. Reservoirs occur at average depths of 2,200 feet with average porosity, permeability, and initial oil saturation of $34 \%, 3,600 \mathrm{mD}$, and $73 \%$ respectively. Average net and gross pay are slightly over 100 feet and 140 feet, respectively. 


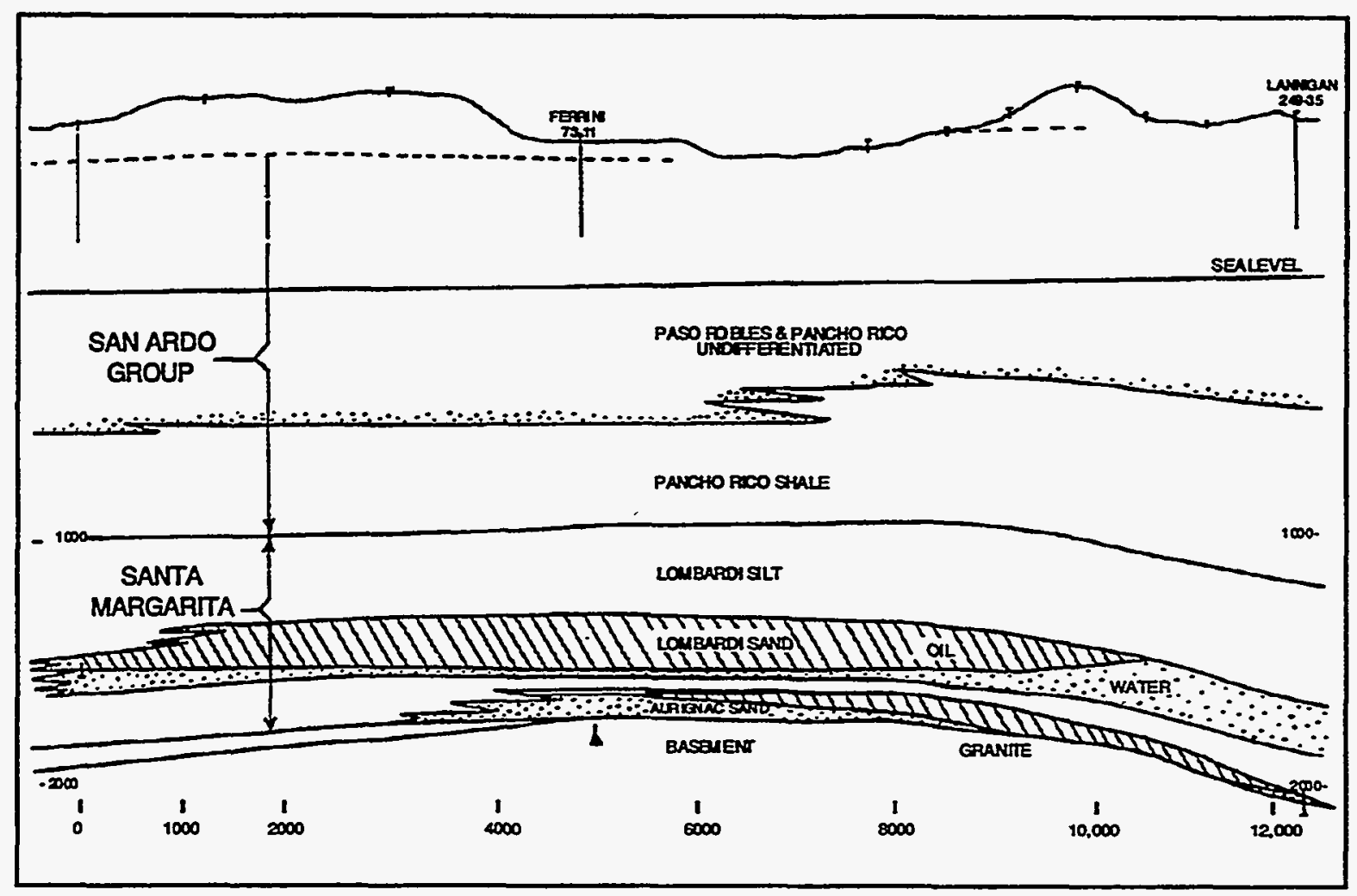

Figure 5.6 Stratigraphic Cross Section Through the California Class 4 San Ardo Field (Source: Baldwin, 1953)

\subsubsection{Improved Oil Recovery Projects}

Steam flooding is the primary recovery process used in the San Ardo-King City Play in California. In the early days of steam flooding, Texaco was very active in developing this process in the San Ardo field. The two major producing reservoirs in the field are the Aurignac and Lombardi sands. Table 5.4 exhibits reservoir properties for the two producing formations based on the TORIS database and data from field operators. Mobil was also active in San Ardo field development using cyclic steam and in situ combustion.

During the early stages of San Ardo field development, Texaco tested an inverted five-spot pilot and a conventional five-spot pattern, both in the Aurignac formation. Results of the steam flood in the two pilot tests indicated that the inverted five-spot pattern recovered oil more efficiently. The average production reported from the inverted five-spot was 401 barrels of oil per day (BOPD) compared to 104 BOPD from the conventional five-spot (Traverse et al., 1983). Using information from the pilot test, a full-scale steam drive was initiated in 1969 by Texaco using a 20-acre inverted nine-spot pattern with three effective producers per injector. Table 5.5 summarizes the results of the steam projects initiated by Mobil and Texaco in the reservoirs of the San Ardo field. Results from these projects have demonstrated that $50 \%$ recovery of the OOIP is achievable. In addition, infill drilling accounted for significant additional recovery representing approximately $10 \%$ of the ultimate field recovery. 


\begin{tabular}{|c|c|c|c|c|c|c|}
\hline \multicolumn{7}{|c|}{ 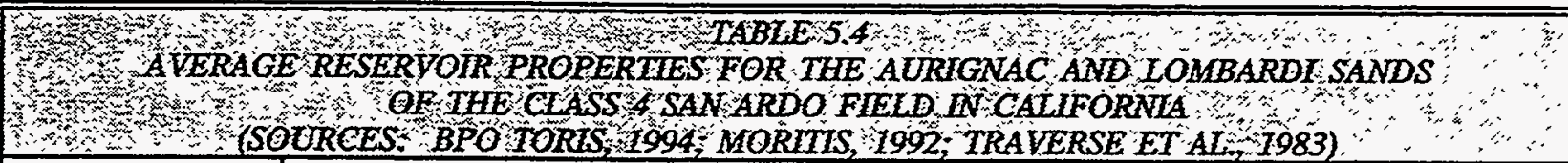 } \\
\hline \multirow[b]{2}{*}{ PARAMETER } & \multicolumn{3}{|c|}{ AURIGNAC RESERVORS } & \multicolumn{3}{|c|}{ LOMBARDI RESERVOIR } \\
\hline & TORIS & MOBIL & TEXACO & TORIS & MOBIL & TEXACO \\
\hline DEPTH, FT & 2,350 & 2,300 & 2,300 & 2,122 & 2,100 & 2,000 \\
\hline NET PAY, FT & 100 & & 97 & 133 & & 103 \\
\hline GROSS PAY, FT & 120 & & & 160 & & \\
\hline POROSITY, \% & 34 & 35 & 35 & 33 & 33 & 35 \\
\hline PERMEABII ITY, $\mathrm{mD}$ & 2,200 & 2,000 & $1,000-3,000$ & 5,000 & 2,250 & $3,000-7,000$ \\
\hline $\begin{array}{l}\text { INITLAL OIL } \\
\text { SATURATION, } \% \\
\end{array}$ & 73 & $\begin{array}{c}55 \\
\text { (Project start) }\end{array}$ & & 74 & $\begin{array}{c}55 \\
\text { (Project start) }\end{array}$ & \\
\hline GRAVITY, ${ }^{\circ}$ API & 12 & 12 & 13 & 11 & 11 & $11-12$ \\
\hline
\end{tabular}

As part of field and reservoir management, Texaco started an extensive program in 1985 to improve the quality of the field's production testing systems. Texaco created a production testing system which delivered a five-fold improvement in testing frequency and reduced the field gauging variability from $\pm 40 \%$ to approximately $\pm 5 \%$ (Christianson et al., 1991).

In addition, Texaco developed a process to shut off steam and water encroachment in production wells. The process involves placing a stable resin across the zone to be shut off. The resin leaks off into the formation where it polymerizes to form an impermeable plug. This resin plug is stable to a temperature of $700^{\circ} \mathrm{F}$ and inert to normal oil field chemicals. Four applications of the resin technology were tested: water entry in production wells, steam cutting in production wells, near surface casing leaks, and injection well leaks (Littlefield et al., 1992). In the San Ardo field, the resin technology was tested in one well for water production, but results were not documented to indicate the success or failure of the test.

Pautz et al. (1992) reported data concerning the Mobil-operated in situ combustion project in the Aurignac reservoir. Production in this 182-acre, 30-well project peaked at $360 \mathrm{BOPD}$. The project began in 1974 and was terminated in 1985 . The project was considered successful.

\begin{tabular}{|c|c|c|c|c|}
\hline \multirow{2}{*}{\multicolumn{5}{|c|}{ 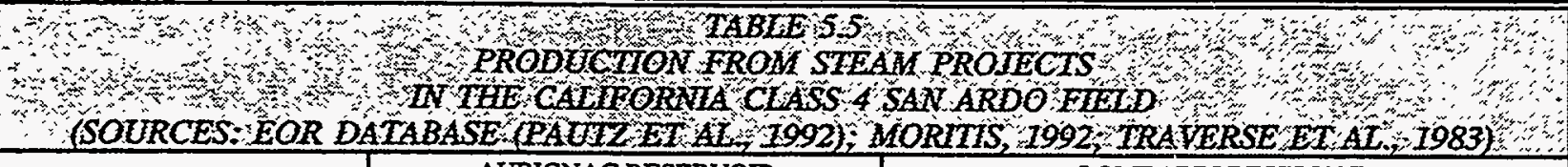 }} \\
\hline & \multicolumn{2}{|c|}{ AURIGNAC RESERVOIR } & \multicolumn{2}{|c|}{ LOMBARDI RESERVOIR } \\
\hline PARAMETER & MOBLL & TEXACO & MOBIL & TEXACO \\
\hline EARLIEST PROJECT DATE & 1964 & 1964 & 1963 & 1965 \\
\hline $\begin{array}{l}\text { MAXIMUM PROJECT SIZE, } \\
\text { ACRES }\end{array}$ & 2,909 & 1,350 & 3,041 & 240 \\
\hline $\begin{array}{l}\text { CURRENT PROJECT SIZE, } \\
\text { ACRES }\end{array}$ & 95 & 240 & 470 & 51 \\
\hline CURRENT NO. WEIIS & 56 & 36 & 128 & 31 \\
\hline $\begin{array}{l}\text { CURRENT EOR } \\
\text { PRODUCTION (BOPD) }\end{array}$ & 3000 & 100 & 1,900 & 2,500 \\
\hline CURRENT STATUS & ACTIVE & ACTIVE & ACTTVE & ACTIVE \\
\hline \multirow[t]{2}{*}{ EOR HISTORY } & $\begin{array}{l}\text { CYCLIC STEAM } \\
\text { AND STEAM } \\
\text { DRIVE } \\
\end{array}$ & $\begin{array}{l}\text { CYCLIC STEAM } \\
\text { AND STEAM } \\
\text { DRIVE }\end{array}$ & $\begin{array}{l}\text { CYCLIC STEAM AND } \\
\text { STEAM DRIVE }\end{array}$ & $\begin{array}{l}\text { CYCLIC STEAM AND STEAM } \\
\text { DRIVE }\end{array}$ \\
\hline & $\begin{array}{l}\text { IN SITU } \\
\text { COMBUSTION } \\
\text { TEST (1974-1985) } \\
\end{array}$ & $\begin{array}{l}\text { CONVERTED TO } \\
\text { HOT WATER IN } \\
1986\end{array}$ & & \\
\hline
\end{tabular}




\subsection{Vaqueros Formation Play, Cuyama Basin, California}

\subsubsection{Play Description}

The Vaqueros Sandstone is one of the major California plays producing from strandline and shoreline/ barrier island depositional environments. Four TORIS Class 4 fields are productive in Vaqueros or equivalent formations: Capitan field and Summerland (offshore) field produce from the Vaqueros; Cuyama South field produces from the Homan reservoir; and Russell Ranch field produces from the Dibblee Sands.

The Vaqueros formation is a late Oligocene to early Miocene Age transgressive sequence of marine strata located in the Cuyama Basin (Figure 5.3) (Lagoe, 1984). Subsidence along a basin margin surrounded by fluvial systems caused the development of barrier bars (i.e., barrier islands of this report) in the Vaqueros (Edwards, 1971). The sands of the barrier bars or barrier islands are coarse-grained and cross-bedded (Edwards, 1971).

Astratigraphic column for the Vaqueros formation (Figure 5.7) shows the basic relationships of the Cuyama Basin rocks in the Caliente Range (Lagoe, 1984). The lowest unit in the Vaqueros is the Quail Canyon Sandstone member which outcrops only in the southeast Caliente Range, but is widespread in the subsurface of Salinas Valley in the Cuyama Basin (Bartow, 1978). It is present along the margins of the Cuyama Valley in the South Cuyama oil field and the Taylor Canyon oil field (Bartow, 1974). The lithology and fossil content suggest a shallow marine environment of deposition (Bartow, 1978).

\begin{tabular}{|c|c|c|c|c|}
\hline AGE & STAGE & \multicolumn{3}{|c|}{ STRA TIGRAPHIC UNTTS } \\
\hline$\dot{i}$ & & \multicolumn{2}{|c|}{ QUATALFM } & \\
\hline \multirow{6}{*}{ 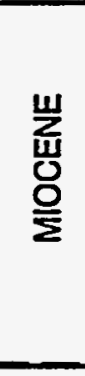 } & MOHNLAN & \multicolumn{2}{|c|}{$\begin{array}{l}\text { SANTA MARGARTA } \\
\text { FM }\end{array}$} & $\begin{array}{l}\text { CAUENT } \\
\text { FM }\end{array}$ \\
\hline & WISIAN & \multirow{3}{*}{ 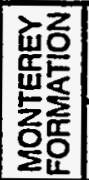 } & $\begin{array}{l}\text { WHTEROCK } \\
\text { BUUFF SHAIE }\end{array}$ & \multirow{3}{*}{\begin{tabular}{|c|} 
BRANCH \\
CANYON \\
SANDSTONE
\end{tabular}} \\
\hline & RELZIAN & & MBR & \\
\hline & \multirow{3}{*}{ SAUCESIAN } & & $\begin{array}{l}\text { SALTOS SHALE } \\
\text { MBR }\end{array}$ & \\
\hline & & \multirow{3}{*}{ 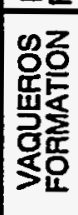 } & \multicolumn{2}{|c|}{$\begin{array}{l}\text { PAINTED ROCK } \\
\text { SANDSTONE MBR }\end{array}$} \\
\hline & & & \multicolumn{2}{|c|}{ SODALAKESHALEMBR } \\
\hline \multirow{2}{*}{ 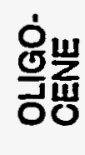 } & \multirow[t]{2}{*}{ ZEMORAAN } & & \multicolumn{2}{|c|}{ QUAILCANYON SANDSTONE MBR } \\
\hline & & \multicolumn{3}{|c|}{ SIMMLER FORMATION } \\
\hline$\dot{8}$ & & \multicolumn{3}{|c|}{$\begin{array}{l}\text { PALEOGENE SEDMENTARY } \\
\text { ROCKS }\end{array}$} \\
\hline
\end{tabular}

Figure 5.7 Stratigraphic Column for the California Class 4 Vaqueros Formation Play (Source: Lagoe, 1984, reprinted by permission) 
The Painted Rock Sandstone member of the Vaqueros formation is a thick clastic unit of shallow marine origin (Yeats et al., 1989). At Caliente Mountain, the Painted Rock Sandstone is more than 6,000 feet thick (Bartow, 1974). In the southwest section, the Painted Rock thins to 300 feet over the granitic basement high where both the Quail Canyon and Soda Lake Members are absent (Bartow, 1974).

The Vaqueros formation was deposited during a rapid transgression from late Oligocene to early Miocene (Osborne and Fritsche, 1987). The western section has marine deposits ranging from offshore to backshore and the eastern section is prodelta, delta front, and delta plain (Osborne and Fritsche, 1987). Rigsby (1989) subdivides the western section of the Vaqueros paleogeographically into barrier/spit, outer shoreface, and inner shelf environments. Sediment reached the Vaqueros shelf from two directions; from the mainland to the east and from the partially emergent trench-slope break in the west (Rigsby, 1989). The sediment sources included Salinian granitic rocks, Franciscan rocks from the north, and granitic and volcanic rocks from the southeast (Edwards, 1971). As transgression crossed the area, the western shoreline was drowned producing filled incised valleys and backstepping shoreline barrier deposits in the eastern part of the region (Rigsby, 1989).

Comparison of the oil produced from fields in the Vaqueros and Monterey formations with rocks in the region suggests the Soda Lake Shale as the most likely source (Lundell and Gordon, 1988).

\subsubsection{Reservoir Characteristics, Models, and Major Controls on Production}

The Oligocene sandstones of the Vaqueros formation at Capitan and Hondo oil fields are defined as shoreline sandstones and conglomerates and inner shelf sandstone facies (Rigsby et al., 1991). Outcrops of the inner shelf sand are burrowed, cross-bedded, gravelly sandstones (Rigsby et al., 1991). At Hondo field, the base of the Vaqueros shows a sharp grain-size change from interbedded fluvial-deltaic sands of the Sespe formation to inner shelf sands of the Vaqueros (Rigsby et al., 1991).

Figure 5.8 shows the position of the Russell Ranch and South Cuyama oil fields in relation to the mountain ranges and faults in the Cuyama Basin (Yeats et al., 1989; Lagoe, 1984). Both of these fields produce light oil from $30^{\circ}$ to $40^{\circ}$ API from the Dibblee and Colgrove reservoir sandstones of the Vaqueros formation (Kornacki, 1988). The Russell Fault in the subsurface of the Cuyama Basin is the controlling structure on oil production for the entire southern Salinian block of coastal California (Yeats et al., 1989). Movement along the fault began in the late Oligocene about 23 million years ago (Yeats et al., 1989).

The lower Miocene Dibblee reservoir sandstone at Russell Ranch field has been interpreted as shoreline barrier island deposition (TORIS). Isopach maps of the field reveal a syncline trending counterclockwise from the Russell Fault (Yeats et al., 1989). Folding along the fault trend formed a very thick deposit of the upper Vaqueros in Russell Ranch field (Yeats et al., 1989). Further evidence of right-lateral displacement along the Russell Fault is found in the South Cuyama field where a tongue of shallow-marine sandstone thins and intertongues with the Saltos Shale Member of the Monterey formation (Yeats et al., 1989). 


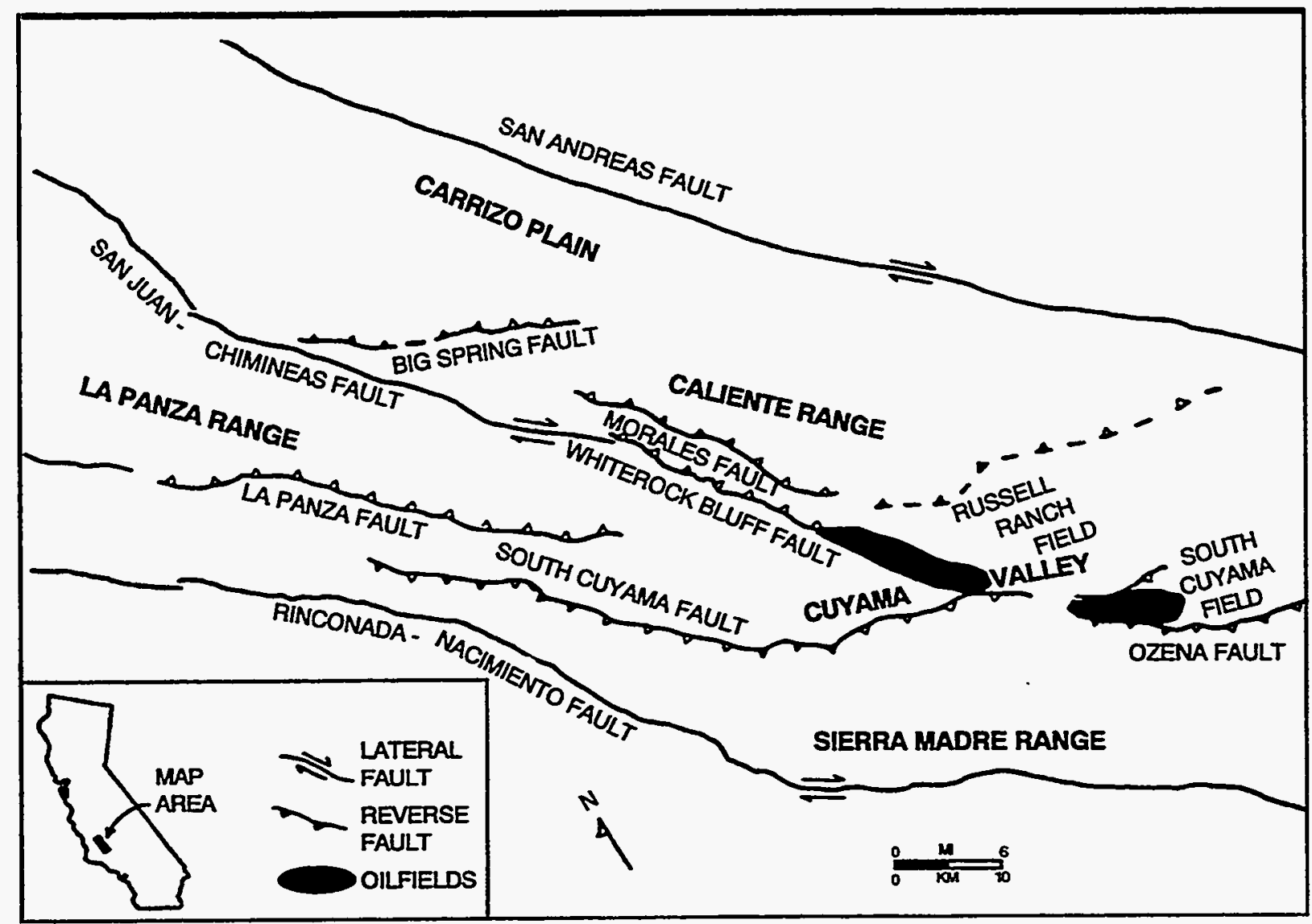

Figure 5.8 Regional Structural Map of Cuyama Basin and Vicinity (Modified from: Yeats et al., 1989, reprinted by permission; Lagoe, 1984, reprinted by permission)

\subsubsection{Production Characteristics}

The Vaqueros Strandplain/Barrier Island Play Class 4 reservoirs average 200 feet of net pay producing light oil with an average gravity of $32^{\circ}$ API. Vaqueros reservoirs are located at average depths of 3,500 feet. Average initial oil saturation was $69 \%$. The average permeability and porosity for Class 4 reservoirs of this play, as reported in the TORIS database, are $169 \mathrm{mD}$ and $26 \%$, respectively. The OOIP is reported at slightly over 1.0 billion barrels with a cumulative recovery of 268 million barrels. The ROIP represents $74 \%$ of the OOIP.

\subsubsection{Improved Oil Recovery Projects}

Although no major IOR projects have been conducted in the reservoirs of this play, waterflooding and gas injection were conducted in South Cuyama and Russell Ranch fields mainly for pressure maintenance (California, 1991 and 1992). 


\subsection{Vedder And Pyramid Hills Play, San Joaquin Valley, California}

\subsubsection{Play Description}

Class 4 production in the Vedder/Pyramid Hills Play comes from six fields: Edison, Greeley, Jasmin, Mount Poso, Round Mountain, and Round Mountain Main fields. Most production comes from different members of the Vedder formation. Some production is realized from the Jewett and Freeman formations.

The Vedder formation has been described as a slope or "ramp" between non-marine and deepmarine deposits (Bloch, 1986). It is a thick subsurface deposit in the eastern San Joaquin Valley of California (Bloch, 1986; Olson, 1988). Several outcrops at Poso Creek and Chalk Cliff (Olson, 1988 ) in the southeastern portion of the San Joaquin Valley are up to 750 feet thick (Block, 1986). Downdip, the Vedder thickens to over 1,500 feet reflecting deposition under conditions of rapid subsidence (Bloch, 1986).

The Vedder (upper Oligocene) and the overlying Jewett (lower Miocene) sandstones are part of a retrogradational parasequence (a landward-stepping series of deposits bounded above and below by marine transgressions) defined by seismic data. Both formations contain a wide variety of alluvial, fluvial-deltaic, and shallow marine facies (Tye et al., 1991). A stratigraphic column (Figure 5.9) shows the relationship of these formations to underlying and overlying sediments (Bartow and McDougall, 1984). A major unconformity developed as the Jewett Sand transgressed over the Vedder (Olson, 1988). A period of rapid subsidence occurred during the late Oligocene and early to mid Miocene, and deposition continued with the Freeman Silt (Olson, 1988). The thick sequence of the Vedder has been described as alluvial, fluvial-deltaic, shallow marine to shoreline barrier origin in the Upper Vedder (Tye et al., 1991; Olson, 1988; and Iyican, 1991). Dean (1986), however, attempted to define the entire Vedder as a submarine fan deposit consisting of offlapping clastic wedges representing deep marine environments.

\subsubsection{Reservoir Characteristics, Models, and Major Controls on Production}

The Vedder, Jewett (Pyramid Hill Member), and Freeman Silt (middle Miocene) are the major oil-bearing sands in the southern San Joaquin Valley (Figure 5.3) (Bartow and McDougall, 1984). Portions of these formations in the Mount Poso and Round Mountain fields have been described as near-shore marine, barrier island, or shoreface deposits. Faulting is of major importance in trapping oil in both Mount Poso and Round Mountain fields.

The main producing horizon at the Mount Poso oil field is a barrier island deposit in the Upper Vedder Sand at a depth of 1,800 feet (Iyican, 1991). Mount Poso field is bounded by sealing faults on both the north and east and is a remarkably homogeneous sand (Iyican, 1991) with good lateral continuity and no major shale breaks (Stokes et al., 1987). Production began at Mount Poso in 1926. Primary production continued until 1971, when steam drive methods took over to produce the heavy, $15^{\circ}$ API gravity oil (Iyican, 1991). Original oil-in-place is estimated at 214 million barrels (Iyican, 1991).

The gross pay zone at Mount Poso field is $70 \mathrm{feet}$, and the net pay zone is $55 \mathrm{feet}$ (Chu, 1983). Mount Poso field is 290 acres in extent and, as of 1983, had 159 producing wells (Chu, 1983). The 


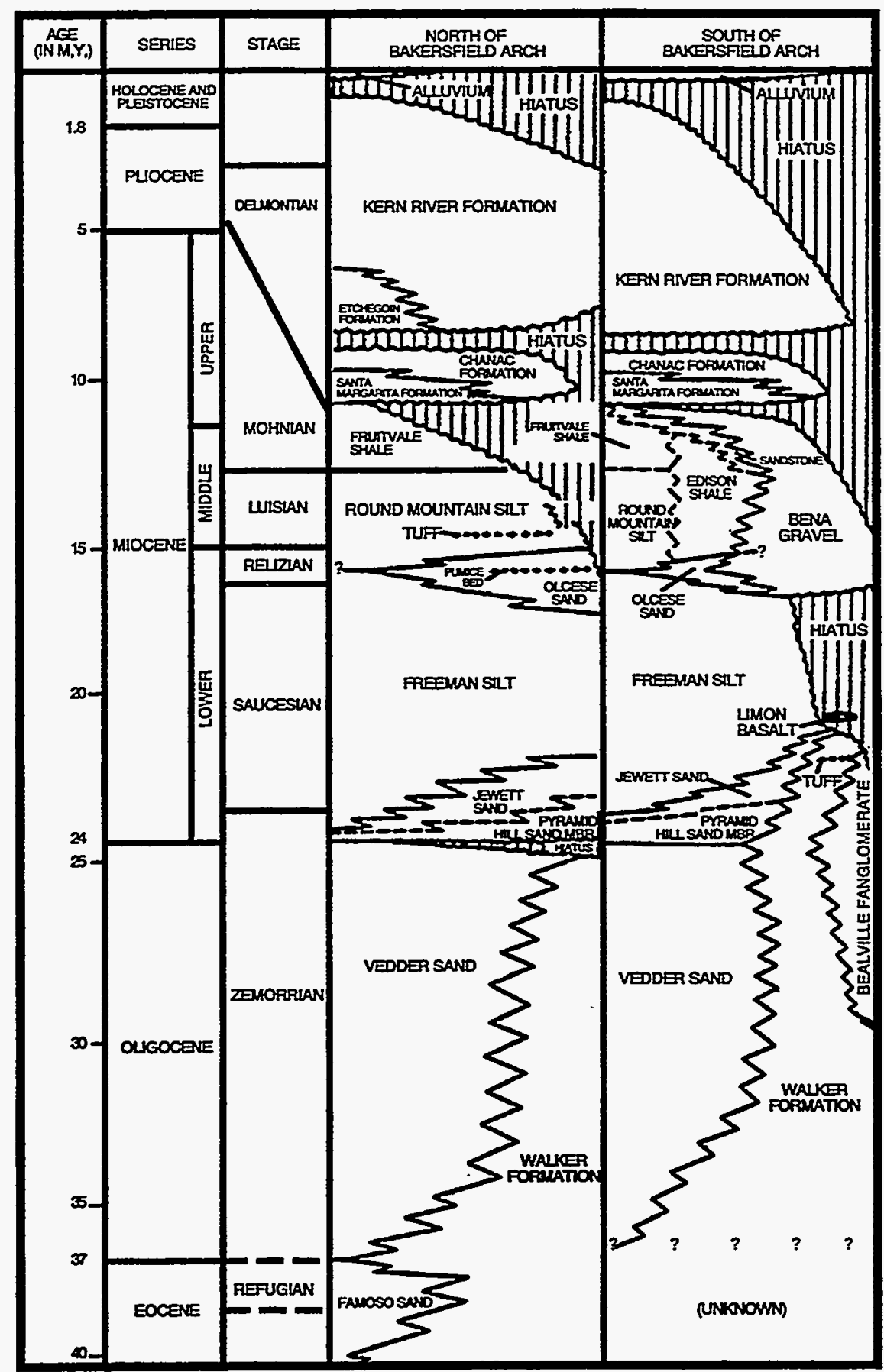

Figure 5.9 Stratigraphic Column for the California Class 4 Vedder Formation Play (Modified from: Bartow and McDougall, 1984, p. 6) 
average porosity for the Upper Vedder Sand at Mount Poso field is 33\% and permeability averages 10 to 20 Darcies (Stokes et al., 1987).

Mount Poso field is a long, narrow, fault-bounded field with a dip of $6^{\circ}\left(\mathrm{O}^{\prime} \mathrm{Dell}\right.$ and Rogers, 1978). The field is an easterly rising homocline (Stokes et al., 1987). The Upper Vedder sand at Mount Poso field is coarse- to medium-grained, well-sorted, subrounded and unconsolidated. Thin silt stringers, probably interdune swale deposits as defined in this report, occur in the Upper Vedder and may inhibit oil flow within the reservoir (Stokes et al., 1987). These stringers are not continuous throughout the field but are correlatable only in small areas. Minor faulting also occurs in the Upper Vedder, but reservoir pressure data indicate no barriers to fluid movement (Stokes et al., 1987).

The Round Mountain oil field produces from several zones in the Upper Oligocene to Mid Miocene parasequences of the Upper Vedder, the Pyramid Hill Member of the Jewett, and the Freeman formations (Harding and Tuminas, 1989). As of 1984, the estimated oil recovery was approximately 92 million barrels (Harding and Tuminas, 1989).

Oil fields in the San Joaquin Valley are excellent examples of the influence of major fault systems on oil entrapment and production. The San Joaquin Valley is a foredeep basin formed by major wrench faults, with normal faults on the flank of the Bakersfield Arch (Harding and Tuminas, 1989). Faulting in the region of the Bakersfield Arch has trapped approximately 700 million barrels of oil reserves (Harding and Tuminas, 1989). The mechanism for oil entrapment is a complex of normal faults (Harding and Tuminas, 1989). The Round Mountain Main and Coffee Canyon reservoirs are sealed by faulting against down-dropped shales, while the Pyramid Hills reservoir is sealed by a large lateral fault which places the reservoir against crystalline basement rocks (Harding and Tuminas, 1989).

\subsubsection{Production Characteristics}

Vedder/Pyramid Hills Class 4 reservoirs are located at an average depth of 3,500 feet producing oil with an average gravity of $22^{\circ}$ API from a net pay thickness of 61 feet. As indicated in the preceding Table 5.2, the average reservoir porosity, permeability, and initial oil saturation are $31 \%$, $1,650 \mathrm{mD}$, and $70 \%$ respectively.

Estimated OOIP for the reservoirs of this play is 1.2 billion barrels with an ultimate recovery of $19 \%$ of the OOIP. The ROIP is approximately 735 million barrels, representing over $60 \%$ of the OOIP.

\subsubsection{Improved Oil Recovery Projects}

Shell's Mount Poso steamflood project is the primary thermal project in the Vedder/Pyramid Hills Play. Mount Poso field is located approximately 14 miles north of Bakersfield, California. Shell began steam flooding the main productive horizon, the Upper Vedder sand, in 1970.

Net pay in the Upper Vedder reservoir averages 55 feet with a net to gross pay ratio of 0.73 (Stokes et al., 1987). Porosity averages $33 \%$ with permeability averaging up to 20 Darcies. Even 
though the $15^{\circ}$ to $16^{\circ} \mathrm{API}$ crude has a viscosity of $280 \mathrm{cP}$ at reservoir temperature, waterdrive primary recovery was high for heavy oil reservoirs-35\% of the OOIP (Stokes et al., 1987).

The project was developed in four phases from 1971 through 1977. In each phase, steam was injected simultaneously for approximately two years into a row of injectors updip near a sealing fault and another row downdip near the oil-water contact. The purpose of downdip injection was to prevent the formation of a cold oil bank ahead of the steam condensation front in the mid-dip region. The field is bounded on the north and east by a sealing fault and on the west and south by a water-oil contact.

Field pilots and extensive physical model studies aided in understanding the process mechanisms and provided a sound basis for project design. Furthermore, a comparison of phase 1 performance with model results showed excellent agreement on a total performance basis. Results of the steam-drive process have increased field reserves significantly by improving the recovery efficiency from $35 \%$ (primary recovery efficiency) to more than $60 \%$.

The project addressed production problems similar to those encountered in most thermal projects (i.e., sand control and lifting of fluids in hot wells). For the most part, these problems were solved with conventional operating techniques.

Two separate simulation studies were conducted by Shell Oil in the Mount Poso field to determine changes in operating policy necessary to optimize financial performance. Results indicated that inert gas and cold water injection can improve the oil-steam ratio for the steam drives from 0.275 to 0.31 . In addition, steam cuts can improve the oil-steam ratio without changes in oil production rates, thereby improving net oil production rate and net income. Additional results are summarized by O'Dell et al. (1978) and Iyican (1991).

\subsection{References}

Baldwin, T.A., 1953, San Ardo field-a geologic case history: Journal of Petroleum Technology, vol. 5, No. 1, January, p. 9-10.

Bartow, J.A., 1974, Sedimentology of the Simmler and Vaqueros formations in the Caliente RangeCarrizo Plain area, California: Stanford University Ph.D. Thesis, 224 p.

Bartow, J.A., 1978, Oligocene continental sedimentation in the Caliente Range area, California: Journal of Sedimentary Petrology, vol. 48, No. 1, p. 75-98.

Bartow, J.A. and K. McDougall, 1984, Tertiary stratigraphy of the southeastern San Joaquin Valley, California: U.S. Geological Survey Bulletin, No. 1529-J, 45 p.

Bloch, R.B., 1986, Ramp-style deposition of Oligocene Marine Vedder formation, San Joaquin Valley, California: American Association of Petroleum Geology Pacific Section Convention, Bakersfield, California, Abstract, American Association of Petroleum Geologists Bulletin, vol. 70, No. 4, p. 463.

California, 1991 and 1992, Annual Reports: Division of Oil, Gas, and Geothermal Resources.

Christianson, B.A. and E.L. Berger, 1991, San Ardo field production testing system upgrade: SPE 21533 International Operations Symposium, Bakersfield, California, p. 111-117. 
Chu, Chieh, 1983, State-of-the-art review of steamflood field projects: SPE 11733 California Regional Meeting, Ventura, California, p. 621-642.

Clarke, S.H., Jr., D.G. Howell, and T.H. Nilsen, 1975, Paleogene geography of California: in D. W. Weaver, G. R. Hornaday and A. Tipton, eds., Paleogene Symposium and Selected Technical Papers, Conference on Future Energy Horizons of the Pacific Coast: Pacific Section, American Association of Petroleum Geologists, Society of Economic Paleontologists and Mineralogists, Society of Exploration Geophysicists, Long Beach, California, p. 121-154.

Dean, J.S., 1986, Depositional model for submarine fan deposits of Vedder Sandstone, Eastern San Joaquin Basin: American Association of Petroleum Geologists Pacific Section Convention, Bakersfield, California, Abstract, American Association of Petroleum Geologists Bulletin, vol. 70 , No. 4, p. 466.

Edwards, L.N., 1971, Paleogeographical interpretation of the Vaqueros and Rincon formations, Ventura Basin, California: 67th Annual Geological Society of America Cordilleran Section Meeting Program, vol. 3, No. 2, p. 115.

Gribi, E.A., Jr., 1963, The Salinas Basin oil province: in Geology of Salinas Valley and the San Andreas Fault: American Association of Petroleum Geologists and Society of Economic Paleontologists and Mineralogists, Pacific Sections, Annual Spring Field Trip Guidebook, Los Angeles, California, American Association of Petroleum Geologists Pacific Section, p. 16-27.

Harding, T.P. and A.C. Tuminas, 1989, Structural interpretation of hydrocarbon traps sealed by basement normal block faults at stable flank of foredeep basins and at rift basins: American Association of Petroleum Geologists Bulletin, vol. 73, No. 7, p. 812-840.

Iyican, L.M., 1991, Mount Poso Upper Vedder simulation study: SPE 21544 Thermal Operations Symposium, Bakersfield, California, p. 201-209.

Kornacki, A.S., 1988, Provenance of oil in southern Cuyama Basin, California: Annual American Association of Petroleum Geologists-Society of Economic Paleontologists and MineralogistsEnergy Minerals Division-Division of Professional Affairs Convention, Houston, Texas, American Association of Petroleum Geologists Bulletin, vol. 72, No. 2, p. 207.

Lagoe, M.B., 1984, Paleogeography of Monterey formation, Cuyama Basin, California: American Association of Petroleum Geologists Bulletin, vol. 68, No. 5, p. 610-627.

Littlefield, B.A., P.D. Fader, and B.W. Surles, 1992, Case histories of new low-cost fluid isolation technology: SPE 24802 67th Annual Technical Conference, Washington, D.C.

Lundell, L. and S. Gordon, 1988, Origin of Cuyama Basin oils: Annual American Association of Petroleum Geologists-Society of Economic Paleontologists and Mineralogists-Society of Exploration Geophysicists, Pacific Sections \& Society of Professional Well Log Analysts Convention, Santa Barbara, California, American Association of Petroleum Geologists Bulletin, vol. 72 , No. 3, p. 386-387.

Miller, H.O., 1953, San Ardo field - a history of development: Journal of Petroleum Technology, vol. 5, No. 1, January, p. 11-13.

Moritis, G., 1992, EOR increases $24 \%$ worldwide; claims $10 \%$ of U.S. production: Oil and Gas Journal, vol. 90, No. 16, April 20, p. 51-79. 
Nilsen, T.H., 1984, Oligocene tectonics and sedimentation, California: Sedimentary Geology, vol. 38, Nos. 1-4, p 305-336.

Nilsen, T.H., 1977, Early Tertiary tectonics and sedimentation in California: in T. H. Nilsen, ed, Late Mesozoic and Cenozoic Sedimentation and Tectonics in California: San Joaquin Valley Geological Society Short Course, Bakersfield, California, p. 86-98.

Nilsen, T.H. and S.H. Clark, Jr., 1975, Sedimentation and tectonics in the Early Tertiary continent borderland of central California: U.S. Geological Survey Professional Paper 925, $64 \mathrm{p}$.

Nilsen, T.H. and E.H. McKee, 1979, Paleogene paleogeography of the Western United States, in J.M. Armentrout, M.R. Cole, and H. TerBest, Jr., eds., Cenozoic Paleogeography of the Western United States: Pacific Section, Society of Economic Paleontologists and Mineralogists, Pacific Coast Paleogeographic Symposium 3, p. 256-276.

O'Dell, P.M. and W.L. Rogers, 1978, Use of numerical simulation to improve thermal recovery performance in the Mount Poso field, California: SPE 7078 5th Symposium on Improved Methods of Oil Recovery, Tulsa, Oklahoma.

Olson, H.C., 1988, Oligocene-Middle Miocene depositional systems north of Bakersfield, California : Eastern Basin Equivalents of the Temblor formation: Society of Economic Paleontologists and Mineralogists, Los Angeles., California, Studies of the Geology of the San Joaquin Basin, p. 189-205.

Osborne, J.G. and A.E. Fritsche, 1987, Stratigraphy and depositional environments of the Vaqueros formation, central and western Santa Monica Mountains, California: 83rd Annual Geological Society of America Cordilleran Section Meeting, Hilo, Hawaii, No. 124851; Abstract With Programs (Geological Society of America) vol. 19, No. 6, p. 437.

Pautz, J.F., C.A. Sellers, C. Nautiyal, and E. Allison, 1992, Enhanced oil recovery projects data base: Department of Energy Report NIPER-583, February, 344 p. plus Appendix D.

Rigsby, C.A., 1989, Nearshore conglomerates of Vaqueros formation, westernmost Santa Ynez Range, Califomia: Annual American Association of Petroleum Geologists-Society of Economic Paleontologists and Mineralogists-Society of Exploration Geophysicists-Society of Professional Well Log Analysts, Pacific Section Meeting, Palm Springs, California, American Association of Petroleum Geologists Bulletin, vol. 73, No. 4, p. 550.

Rigsby, C.A., G.A. Miles, and D.E. Schwartz, 1991, Lithostratigraphy and depositional environments of the Vaqueros formation in Hondo field, Capitan field, and the western Santa Ynez Mountains, California: Annual American Association of Petroleum Geologists-Society of Economic Paleontologists and Mineralogists-Society of Exploration Geophysicists-Society of Professonal Well Log Analysts, Pacific Section Meeting, Bakersfield, California, American Association of Petroleum Geologists Bulletin, vol. 75, No. 2, p. 378.

Stokes, D.D., J.R. Brew, D.G. Whitten, and L.W. Wooden, 1987, Steam drive as a supplemental recovery process in an intermediate-viscosity reservoir, Mount Poso field, California: EOR Field Case Histories (SPE Reprint Series No. 23), Society of Petroleum Engineers, Richardson, Texas, p. 348-354.

Traverse, A.D., A.D. Deibert, and A.J. Sustek, 1983, San Ardo-a case history of a successful steamflood: SPE 11737 California Regional Meeting, Ventura, California, p. 665-672. 
Tye, R.S, J.S. Hewlett, P.R. Thompson, and D.K. Goodman, 1991, Integrated analysis of parasequences in an Oligocene transgressive systems tract : San Joaquin Basin, California: Annual American Association of Petroleum Geologists-Society of Economic Paleontologists and Mineralogists-Society of Exploration Geophysicists-Society of Professonal Well Log Analysts, Pacific Section Meeting-Division of Professional Affairs Convention, Dallas, Texas, American Association of Petroleum Geologists Bulletin, vol. 75, No. 3, p. 684.

Yeats, R.S. J.A. Calhoun, B.B. Nevins, H.F. Schwing, and H.M. Spitz, 1989, Russell Fault : early strike-slip fault of California Coast Ranges: American Association of Petroleum Geologists Bulletin, vol. 73, No. 9, p. 1089-1102. 


\section{CHAPTER 6 \\ MAJOR ROCKY MOUNTAIN STRANDPLAIN/BARRIER ISLAND PLAYS}

The strandplain/barrier island reservoirs in the Rocky Mountain region represent a significant portion of the Class 4 resource in the country, as defined in the DOE Tertiary Oil Recovery Information System (TORIS). The Class 4 resource in the Rocky Mountain states is found in four significant plays or groups of plays: the Muddy Plays in Wyoming and Montana; the Gallup Barrier Island Play in New Mexico; the D-J Plays in the Denver Basin; and other strandplain/barrier island plays in Colorado, Montana, and Wyoming. This chapter describes the geologic characteristics of these plays relative to the trapping and production of hydrocarbons.

The reservoir and production characteristics of the Rocky Mountain Class 4 plays are summarized in this chapter based on the analysis of almost 60 reservoirs contained in the TORIS database and review of the technical literature. This analysis indicates that reservoirs in these plays exhibit fairly poor reservoir quality and recovery. Production has been impacted by the application of improved recovery processes. Based on literature review, the improved recovery processes which have shown favorable results in the Rocky Mountain Class 4 plays include: polymer flooding, gel polymer treatments, cyclic $\mathrm{CO}_{2}$ stimulation treatments, and surfactant flooding. Significant potential exists for further application of improved recovery technologies in Rocky Mountain Class 4 reservoirs (See Chapters 7 and 8).

\subsection{Overview of Rocky Mountain Plays}

Rocky Mountain states contain 2.1 billion barrels of remaining oil-in-place (ROIP) in Class 4 reservoirs, representing 11\% of the ROIP for Class 4 reservoirs listed in the TORIS database (Table 6.1). Fields are generally in a very mature state with over $97 \%$ of the estimated ultimate recoverable oil with current operations already having been produced. Cumulative recovery is $32 \%$ of the OOIP. Remaining reserves with current operations are estimated to be less than 30 million barrels (versus cumulative production of 1.0 billion barrels).

About $44 \%$ of the ROIP in the Rocky Mountain states is contained in Wyoming's Muddy Plays. Another $26 \%$ is contained in New Mexico's Gallup Barrier Island Play, followed by the D-J Plays in the Denver Basin with 10\%, and other plays in Colorado, Montana, and Wyoming contributing the remaining $20 \%$. The ROIP volumes and average reservoir parameters, calculated from TORIS reservoir data, for these plays are summarized in Table 6.2. Some production from reservoirs variously interpreted as being a strandplain/barrier island origin also occurs in the Frontier formation of Wyoming.

Class 4 production is primarily light oil from moderate depth reservoirs. Net pay ranges from 18 to 45 feet. Average permeability ranges from a low of $33 \mathrm{mD}$ in the Gallup Barrier Island Play to a high of $478 \mathrm{mD}$ in the D-J Plays. Estimated ultimate recovery efficiencies with current operations in the Muddy, Gallup Barrier Island, and D-J Plays are 28, 14, and 24\% respectively. 


\begin{tabular}{|c|c|c|c|c|c|}
\hline \multicolumn{6}{|c|}{ 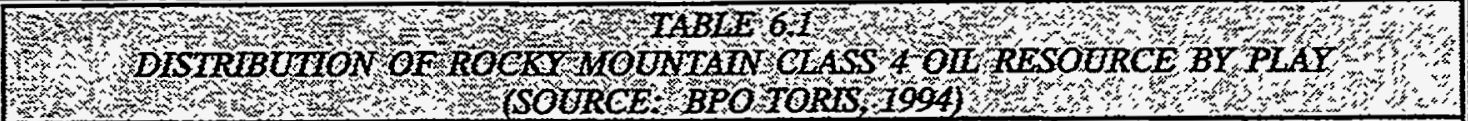 } \\
\hline PLAY & STATE & $\begin{array}{l}\text { ORIGINAL } \\
\text { OIL-IN-PLACE } \\
\text { MMBO }\end{array}$ & $\begin{array}{l}\text { CUMULATTVE } \\
\text { RECOVERY } \\
\text { MMBO }\end{array}$ & $\begin{array}{l}\text { REMAINING } \\
\text { OIL-IN-PLACE } \\
\text { MMBO }\end{array}$ & $\begin{array}{l}\text { NUMBER } \\
\text { OF RESERVOIRS }\end{array}$ \\
\hline LOWER CRETACEOUS STRANDPLAIN SS & $\overline{W Y}$ & 1,035 & 252 & 782 & 16 \\
\hline CRETACEOUS MUDDY NEARSHORE SS & MT & 224 & 130 & 92 & 1 \\
\hline LOWER CRETACEOUS MUDDY ESTUARNE SS & WY & 54 & 30 & 24 & 1 \\
\hline $\begin{array}{l}\text { LOWER CRETACEOUS SS COMMINGLED-SW } \\
\text { WY }\end{array}$ & WY & 61 & 39 & 22 & 1 \\
\hline SUBTOTAL MUDDY PLAYS & & 1,374 & 450 & 920 & 19 \\
\hline GALLUP BARRIER ISLAND & $\mathrm{NM}$ & 651 & 104 & 546 & 8 \\
\hline DJ CAMBRIDGE ARCH & NE & 242 & 116 & 120 & 10 \\
\hline DAKOTA BARRIER ISLAND & $\mathrm{NM}$ & 50 & 20 & 26 & 3 \\
\hline DENVER BASIN D-J SANDS & $\mathrm{CO}$ & 31 & 8 & 24 & 3 \\
\hline $\begin{array}{l}\text { NW CO CRETACEOUS DAKOTA CHANNEL } \\
\text { SANDS }\end{array}$ & $\mathrm{CO}$ & 28 & 9 & 19 & 1 \\
\hline $\begin{array}{l}\text { LOWER CRETACEOUS DAKOTA STRANDPLAIN } \\
\text { SS }\end{array}$ & WY & 25 & 13 & 12 & 2 \\
\hline SAN JUAN BASIN DAKOTA-MORRISON SANDS & $\mathrm{CO}$ & 19 & 7 & 12 & 1 \\
\hline SUBTOTALD-J PLAYS & & 396 & 173 & 212 & 20 \\
\hline VINTA-PICEANCE BASIN MORRISON SANDS & $\mathrm{CO}$ & 163 & 58 & 104 & 1 \\
\hline CENTRAL MONTANA STRUCTURAL TRAP & $\mathbf{M T}$ & 115 & 23 & 91 & 1 \\
\hline $\begin{array}{l}\text { UPPER CRETACEOUS ALMOND BARRIER } \\
\text { BARS SW WY }\end{array}$ & WY & 194 & 91 & 100 & 2 \\
\hline TRIASSIC NEARSHORE SS-BIG HORN BASIN & WX & 116 & 59 & 54 & 2 \\
\hline MIDDLE CAMBRIAN FLATHEAD SS-SW WY & WY & 50 & 13 & 37 & 1 \\
\hline $\begin{array}{l}\text { UPPER CRETACEOUS PARKMAN SS-POWDER } \\
\text { RIVER }\end{array}$ & $\mathbf{W Y}$ & 26 & 11 & 15 & 1 \\
\hline $\begin{array}{l}\text { UPPER CRETACEOUS MESAVERDE SS-WIND } \\
\text { RIVER }\end{array}$ & $\mathbf{W Y}$ & 20 & 8 & 11 & 1 \\
\hline $\begin{array}{l}\text { UPPER MISSISSIPPIAN DARWIN } \\
\text { STRANDPLAIN-SW WY } \\
\end{array}$ & WY & 13 & 3 & 10 & 1 \\
\hline $\begin{array}{l}\text { TRANSGRESSTVE AMSDEN DEPOSTIS } \\
\text { BIGHORN BASIN }\end{array}$ & WY & 13 & 5 & 7 & 1 \\
\hline SUBTOTAL OTHER PLAYS & & 711 & 271 & 428 & 11 \\
\hline $\begin{array}{l}\text { TOTAL WYOMINGROCKIES } \\
\text { PLAYS }\end{array}$ & & 3,131 & 998 & 2,106 & 58 \\
\hline
\end{tabular}

The Lower Cretaceous (Albian) Muddy Sandstone is the uppermost member of the Dakota Group and is correlative with the J Sandstone in the Denver Basin of eastern Colorado, the Vaughan Bow Island sandstones of Montana, parts of the Bear River formation in the Overthrust belt of Utah and Wyoming, and the Viking formation in Canada.

The Muddy Sandstone is a relatively thin stratigraphic interval, usually less than 100 feet thick, that is characterized by a wide variety of marine and nonmarine depositional paleoenvironments resulting in rapid vertical and lateral facies changes. The sequence of depositional environments found in the Muddy Sandstone and correlative formations was controlled by changes in sea level and consists of (from older to younger): (1) strandplain/barrier island deposits formed during a sea level drop (regression); (2) valley fill and fluvial channel deposits formed during a sea level drop and subsequent sea level rise (transgression); and (3) strandplain/barrier island deposits formed during a sea level rise (transgression). 


\begin{tabular}{|c|c|c|c|c|c|}
\hline 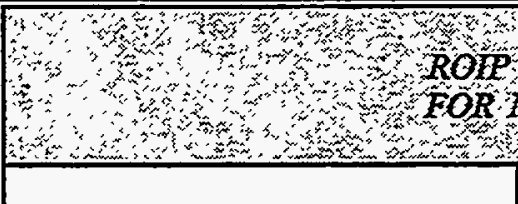 & 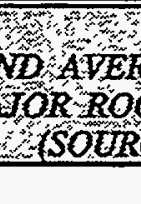 & $\begin{array}{l}\text { BEE } 62 \\
\text { RESER } \\
\text { ROUNTA } \\
\text { BPOTOR }\end{array}$ & 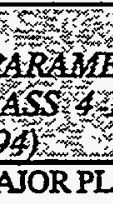 & 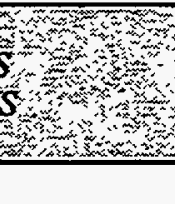 & 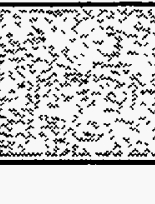 \\
\hline PARAMETER & $\begin{array}{c}\text { MUDDY } \\
\text { PLAYS }\end{array}$ & $\begin{array}{c}\text { GALUUP } \\
\text { BARRIER } \\
\text { ISLAND }\end{array}$ & $\begin{array}{c}\text { D-J } \\
\text { PLAYS }\end{array}$ & $\begin{array}{c}\text { OTHER } \\
\text { WYOMING } \\
\text { ROCKIES }\end{array}$ & $\begin{array}{l}\text { OVERAII } \\
\text { AVERAGE } \\
\text { VALUES }\end{array}$ \\
\hline REMAINING OIL-IN-PLACE, MMBO & 920 & 546 & 212 & 428 & \\
\hline NET PAY,FT & 18 & 24 & 20 & 45 & 27 \\
\hline POROSITY, \% & 18 & 12 & 21 & 16 & 17 \\
\hline INITIAL OIL SATURATION, \% & 71 & 66 & 69 & 71 & 69 \\
\hline DEPTH, FT & 6,878 & 4,604 & 4,377 & 5,408 & 5,317 \\
\hline PERMEABILTTY, mD & 83 & 33 & 478 & 82 & 169 \\
\hline GRAVIT, ${ }^{\circ}$ API & 39 & 42 & 34 & 35 & 37 \\
\hline INITIAL PRESSURE, PSI & 2,849 & 1,855 & 1,725 & 2,190 & 2,155 \\
\hline ULTIMATE RECOVERY, $\%$ & 28 & 14 & 24 & 46 & 28 \\
\hline
\end{tabular}

The Muddy Sandstone and equivalent strata have produced more than 1.5 billion bbl of oilequivalent hydrocarbons. Cumulative production volumes for valley fill and channel, transgressive marine and older marine reservoirs are 359, 315 and 268 million barrels of oil-equivalent hydrocarbons, respectively (Dolson et al., 1991).

Major oil companies produced nearly two-thirds of the 1991 production from Class 4 reservoirs in the Rocky Mountain region (Figure 6.1). Small independent operators produced 29\% of 1991 production, while midsize and large independent operators each produced 3\% of 1991 production. Annual production volumes since 1970 from the Wyoming/Montana Muddy Plays, the Gallup Barrier Island Play, and the D-J Sand Plays are illustrated in Figure 6.2. Shallow production declines reflect the maturity of the production.

Historical improved oil recovery activity in Rocky Mountain Class 4 reservoirs is summarized in Table 6.3. Most activity has been in the Muddy and D-J Plays with polymer flooding representing the most widely used process. None of the three surfactant projects, two in the Bell Creek field and one in the Big Muddy field, are currently active. The in situ combustion project in the Hospah South field in New Mexico has also been terminated. Individual well gel polymer and cyclic $\mathrm{CO}_{2}$ stimulation treatments, some of which are known to have been performed in Class 4 reservoirs, are not listed in Table 6.3.

\begin{tabular}{|c|c|c|c|}
\hline \multicolumn{3}{|c|}{ 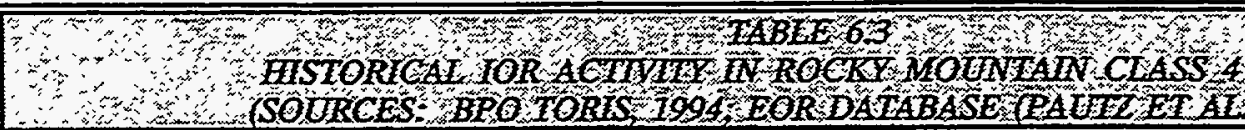 } & 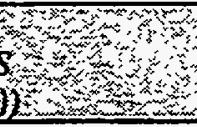 \\
\hline BY PLAY & $\begin{array}{c}\text { NO. OF } \\
\text { PROJECTS }\end{array}$ & BY PROCESS & $\begin{array}{c}\text { NO. OF } \\
\text { PROJECTS }\end{array}$ \\
\hline MUDDY PLAYS & 6 & POLYMER & $\overline{7}$ \\
\hline GAILUP BARRIER ISLAND & $\overline{1}$ & GEL POLYMER & 1 \\
\hline D-J PLAYS & $\overline{5}$ & SURFACTANT & $\overline{3}$ \\
\hline OTHER PLAYS & & IN SITU COMBUSTION & 1 \\
\hline TOTAL ALL PLAYS & 12 & TOTAL ALI PLAYS & $\overline{12}$ \\
\hline
\end{tabular}




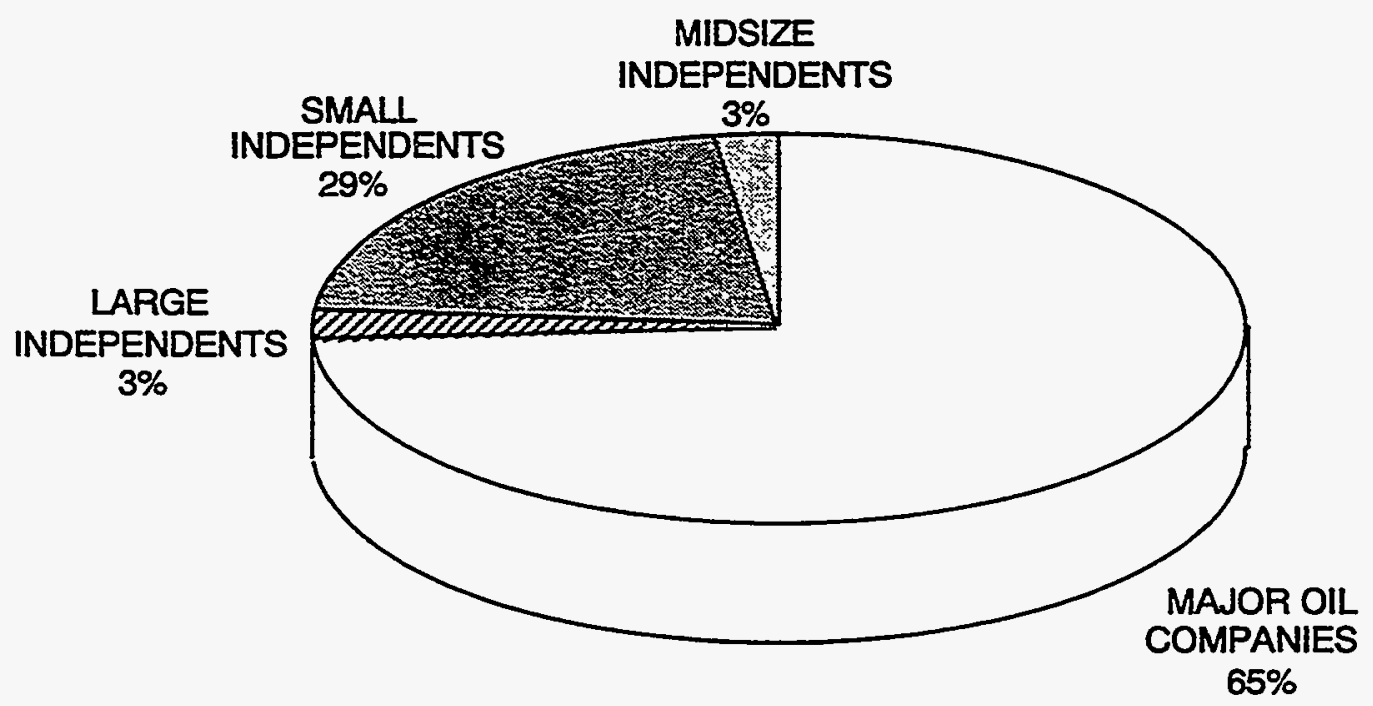

Figure 6.1 Operator Profile for Rocky Mountain Class 4 Reservoirs (Source: BPO TORIS, 1994)

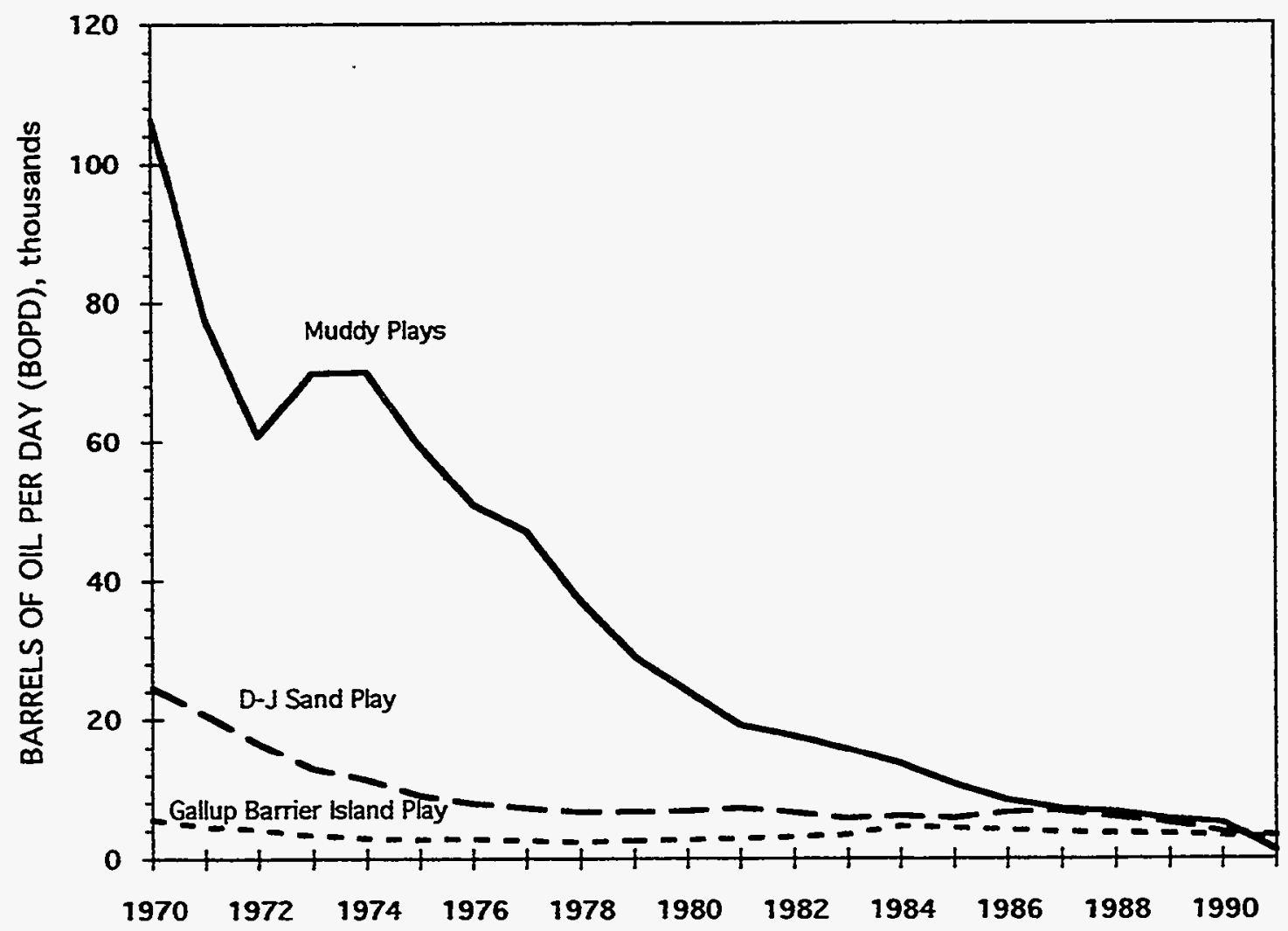

Figure 6.2 Historical Production for Major Rocky Mountain Class 4 Plays (Source: BPO TORIS, 1994) 


\subsection{Muddy, Dakota, and Equivalent Formations Strandplain/Barrier Island Plays}

Because Rocky Mountain Class 4 reservoirs have many similarities in terms of geological and production characteristics, they will be discussed together in the following sections. Most emphasis will be placed on the Muddy Sandstone, a play which is considered to be representative of the other formations in the combined play. Improved oil recovery projects, however, will be discussed separately for each formation or sub-play.

\subsubsection{Play Description}

The Lower Cretaceous (Albian) Muddy Sandstone is the uppermost member of the Dakota Group and is bounded by the Skull Creek Shale below and the Mowry Shale above (Figure 6.3). The formations correlative with the Muddy Sandstone are the J Sandstone in the Denver basin of eastern Colorado, the Vaughan Bow Island sandstones of Montana, parts of the Bear River formation in the Overthrust belt of Utah and Wyoming, and the Viking formation in Canada. The Dakota Sandstone of Utah and northwestern Colorado is equivalent to or younger than the Muddy Sandstone of Wyoming.

The Muddy Sandstone is a relatively thin stratigraphic interval, usually less than 100 feet thick, that is characterized by a wide variety of marine and nonmarine depositional paleoenvironments resulting in rapid vertical and lateral facies changes. The complex stratigraphic and lithofacies relationships within and between members of the Muddy and the presence of subaerial unconformities within the Muddy are evidence of a complicated interplay between both regional and local basin tectonics and eustatic sea-level changes during Muddy time.

Dolson et al. (1991) outline the following three predominant rock assemblages found in the Muddy Sandstone:

- Fine-grained to conglomeratic lithic and quartz arenites containing abundant coaly debris, shale rip-up clasts, erosive basal contacts, and trough and planar cross-bedding. These assemblages are most commonly point bar, braided stream, or fluvial channel deposits.

- Fine to very fine-grained quartz arenites (occasionally arkosic) with either gradational or sharp bases, abundant to moderate trace fossils, horizontal to low-angle laminations, and occasional cross-bedding. This facies generally comprises beach, barrier island or offshore bar standstones. Gradational lower contacts occur in units conformable with the Skull Creek Shales. Sharp lower contacts are associated with unconformities.

- Interbedded black organic-rich fissile shales, coals, and waxy green shales (relatively rare) interbedded with thinly bedded sandstones containing ripple or wavy laminations. This facies can occur within lagoon, overbank and splay deposits or abandoned channel fills.

The sequence of depositional environments found in the Muddy Sandstone and correlative rocks result from sea level changes. Initial Muddy deposition, time T1 on Figure 6.4, consisted of strandplain/barrier island sands that prograded seaward during a sea-level highstand and subsequent regression. The shoreline regressed from the position indicated at time $\mathrm{T} 1$ to the position of time T2 (Figure 6.4). Examples of these strandplain/barrier island sandstones include the Rozet 


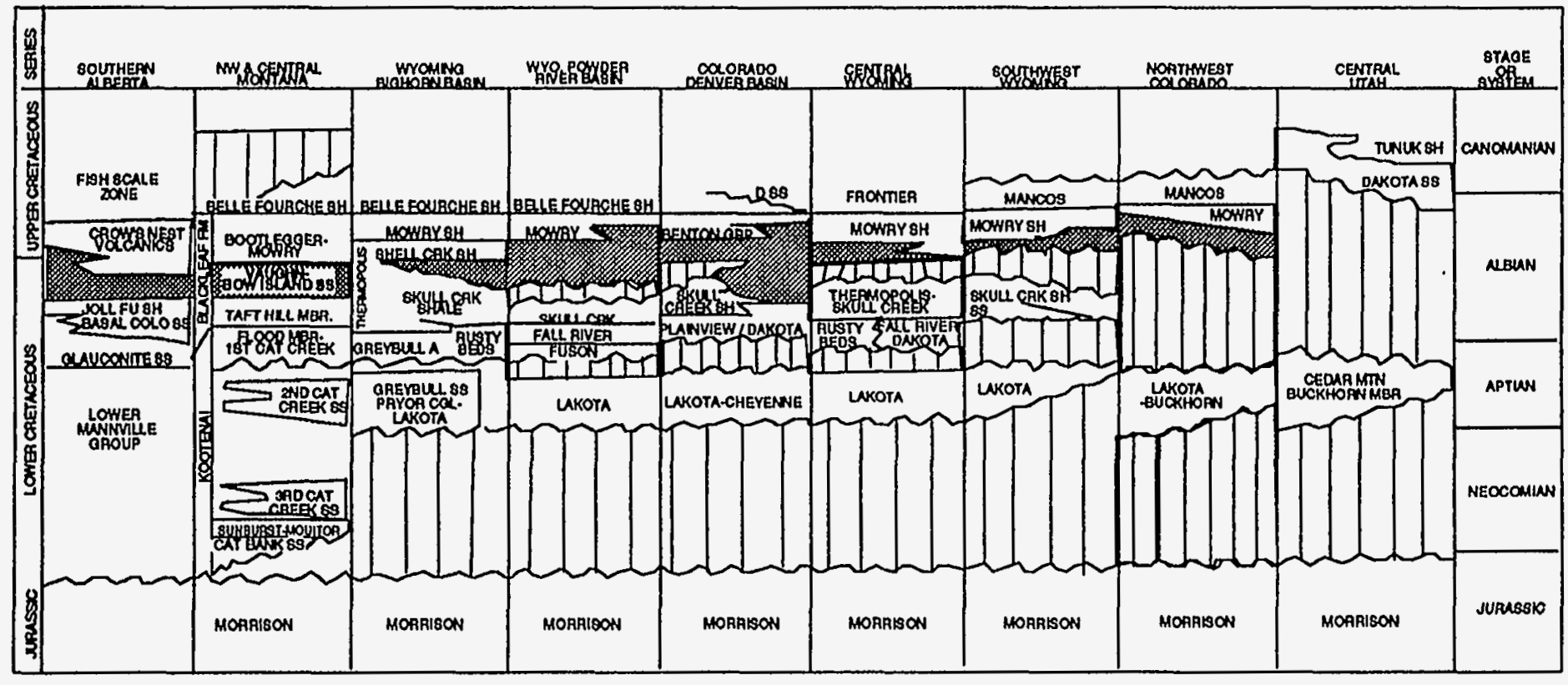

Figure 6.3 Stratigraphic Correlation Chart of Cretaceous Rocks in the Rocky Mountian Region; Muddy Sandstone and Correlative Rocks are Indicated by Shading. (Modified from: McGookey, 1972) 
member, Lazy B and the Bell Creek field Muddy formation of the Powder River Basin (Gustason et al., 1986); the Fort Collins member of the Denver Basin (Mac Kenzie, 1971); and the J-3 sand of the Denver Basin (Dolson and Nibbelink, 1985). These sandstones are the older marine or maximum regression shoreline sandstones of Dolson et al. (1991).

Recurrent movement along basement faults created structural and topographically high areas. A sea level drop caused a regional erosional surface at time T3 (Figure 6.4), and a drainage system was incised by erosion into and/or through the strandplain/barrier island sandstones deposited during T1 and T2. The erosional surface is referred to as the lowstand surface of erosion (LSE). The topographic lows created by basement fault movement controlled the location of the drainage systems and the subsequent valley incisement (Figure 6.4). As the sea-level rose, the incised drainage valleys were inundated by the sea and filled with sediments. The resultant valley fill deposits are the Recluse, Cyclone, Ute and Springen Ranch members in the Powder River Basin (Gustason et al., 1986); the Horsetooth member in the Denver Basin (MacKenzie, 1971) and parts of the J-2 sand in the Denver Basin (Dolson et al., 1991)

Individual valley widths range from tens of miles to hundreds of feet. Internal valley fills are highly variable, representing a spectrum of sedimentary environments and lithologies. Valley fill sediments can consist of both fluvial and marine sandstones or may be dominantly shale, depending upon the availability of sediment during transgression.

In spite of continued sea level rise, barrier island sequences, referred to as transgressive marine deposits by Dolson et al. (1991), formed over the valley fill deposits (not shown in figure). Muddy Sandstone deposition ended with the deposition of overlying marine Mowry Shale.
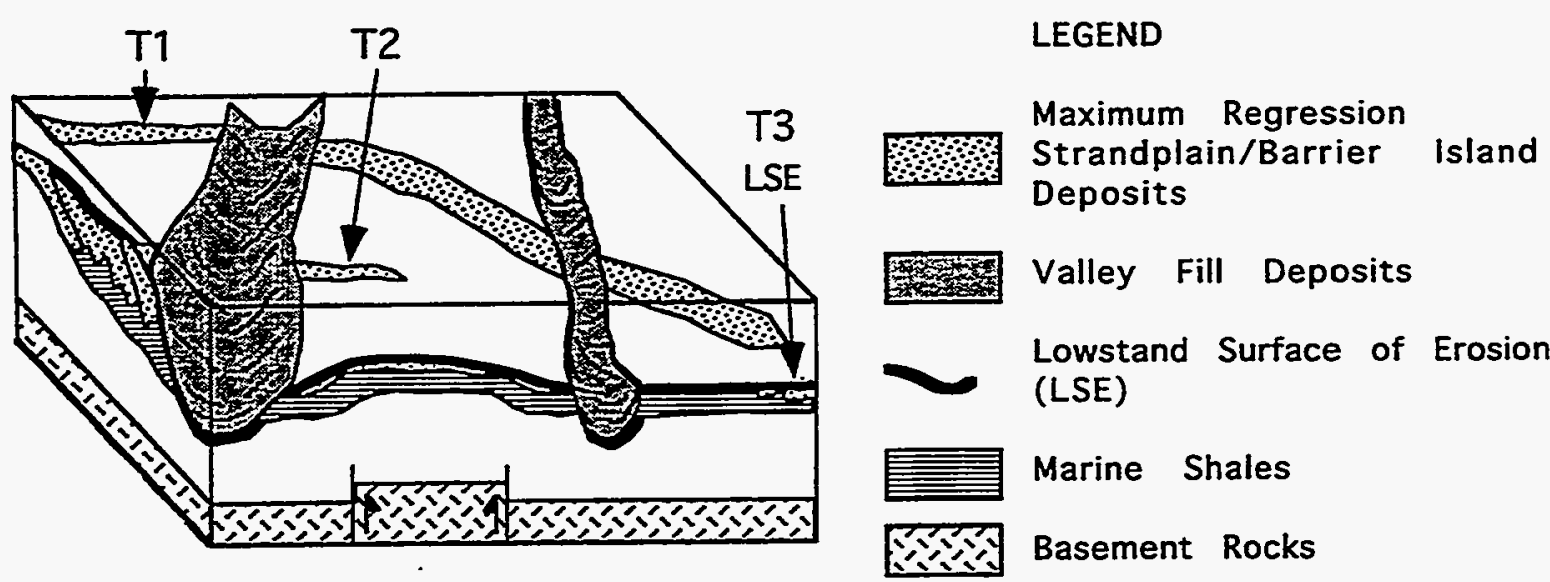

Figure 6.4 Stratigraphic Model for Sequence of Deposition of the Muddy Sandstone (Modified from: Weimer et al., 1982) 


\subsubsection{Reservoir Models, Reservoir and Production Characteristics}

Production from the Muddy Sandstone and equivalent lower Cretaceous strata is present in many basins in the northern Rocky Mountain states of Montana, Wyoming, Utah and Colorado (Figure 6.5). The Muddy Sandstone and equivalent strata have produced more than 1.5 billion barrels of oil-equivalent hydrocarbons (Dolson et al., 1991). Significant reserves are still being discovered after nearly 70 years of continuous exploration. No production in the Muddy Sandstone has been established in the Williston or Paradox basins or in north-central Montana, probably due to burial depth insufficient to generate hydrocarbons from Mowry and Skull Creek Shale source rocks (Burtner and Warner, 1984).

Patterns of production are related to combinations of favorable Laramide structure, diagenesis, hydrodynamics, migration paths and burial history. High-quality reservoirs are most commonly developed within or near major valley systems where an adequate sediment supply was available for reservoir development and preservation during transgression. Where the Muddy Sandstone is thin on intervening regional divides or within lowstand basins, production is usually poor with little or no reservoir developed.

A fair correlation exists between porosity and permeability independent of Muddy Sandstone depositional environments within producing fields (Dolson et al., 1991). No clear relationships exist between porosity and depth for producing fields in any formation of the Dakota Group. The development of secondary dissolution porosity is cited as a major factor in the lack of clear-cut correlation between porosity and depth (Dolson et al., 1991).

Anomalously high porosity at depth has been encountered, primarily on the Moxa Arch, Wyoming. Here, porosity can exceed $20 \%$ with permeability in excess of 1 Darcy at 15,000 feet, primarily from coarse-grained, channel sandstones (Dolson et al., 1991). This porosity results from dissolution of intergranular calcite and dolomite cement.

Work conducted by Almon and Davies (1979) indicates that diagenetic clay mineral assemblages can be equated to specific, equivalent sedimentologic units (different reservoir zones). The older marine sandstones (e.g., Bell Creek field sand) are characterized by a kaolinite-chlorite-illitequartz assemblage with some smectite. The valley and channel fills of the Muddy Sandstone are characterized by an illite-smectite assemblage with sporadic chlorite, quartz and kaolinite. The transgressive marine Muddy sandstones are characterized by a kaolinite-quartz assemblage.

Well stimulation and completion treatment design should consider the diagenetic assemblages present in the reservoir sandstones. In the oldest Muddy Sandstones, the rocks will tend to be acid sensitive, occasionally fresh water sensitive, and there will be migration of fines. In the younger Muddy sandstones, the principal problem will be the migration of fines and the stabilizing of the kaolinite.

Muddy Sandstone reservoirs typically are underpressured at shallow depths and overpressured below 10,000 feet. Drive mechanism is commonly solution gas. Most fields require secondary recovery early in the field history and depletion rates are rapid without pressure maintenance.

Cumulative production and reservoir properties for representative fields are presented in Table 6.4. Production can be related to the various Muddy Sandstone reservoir types (Figure 6.6). 


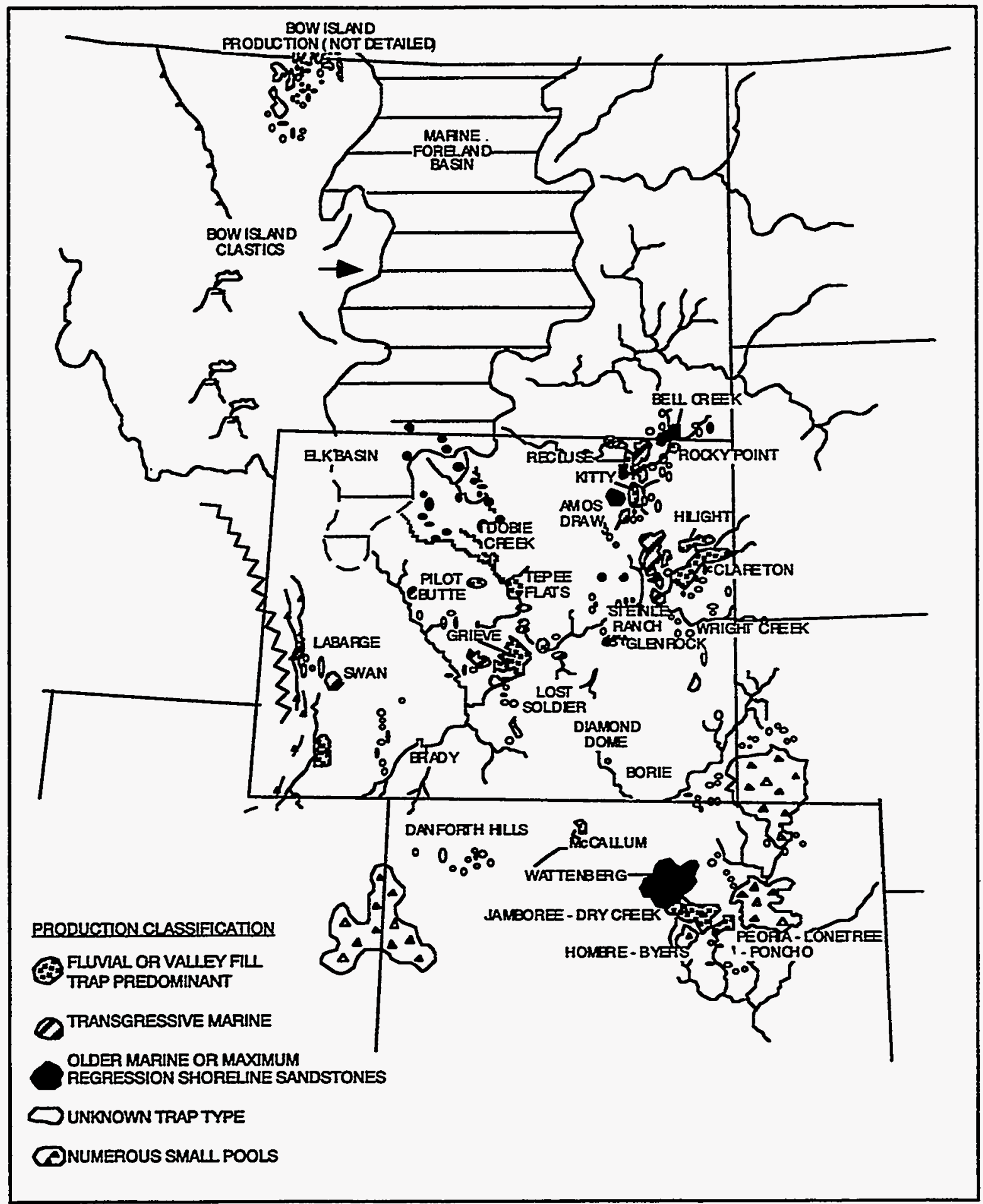

Figure 6.5 Depositional Classification of Selected Muddy Sandstone Fields. See Table 6.4 Reservoir Characteristics for Some of the Fields Shown (Modified from: Dolson et al, 1991, reprinted by permission) 


\begin{tabular}{|c|c|c|c|c|c|c|c|}
\hline \multicolumn{8}{|c|}{ 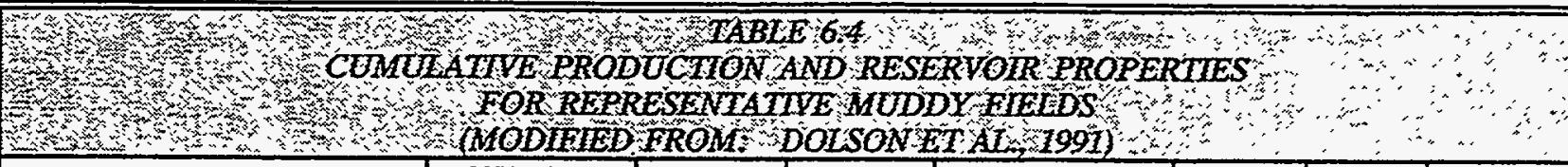 } \\
\hline FIEID NAME & FORMATION & $\begin{array}{l}\text { TRAP } \\
\text { STATE }\end{array}$ & TYPE & ENVIRONMENT & MMBO & $\begin{array}{l}\text { BCF } \\
\text { GAS }\end{array}$ & MMBOE \\
\hline BEI L CREEK & $\mathrm{KMD}$ & $\mathrm{MT}$ & STRAT & $\mathrm{OM}$ & 124 & 39 & 130 \\
\hline HIIGETT & $\mathrm{KMD}$ & WY & STRAT & $\mathrm{TM}, \mathrm{VF}$ & 74 & 227 & 113 \\
\hline WATTENBERG & $\mathrm{KMD}$ & $\mathrm{CO}$ & STRAT & $O M$ & 4 & 415 & 72 \\
\hline ADENA & $\mathrm{J}$ & $\mathrm{CO}$ & STRAT & $\overline{T M}$ & 59 & 71 & 71 \\
\hline CHURCH BUTTES & $\mathrm{KO}$ & WY & $\mathrm{COMB}$ & $\mathrm{CH}$ & 2 & 300 & 54 \\
\hline GRETVE & $\mathrm{KMD}$ & WY & STRAT & VF & 29 & 68 & 41 \\
\hline RECLUSE & $\mathrm{KMD}$ & WY & STRAT & VF & 22 & 94 & 38 \\
\hline KITTY & KMD & WY & STRAT & VF & 19 & 88 & 35 \\
\hline GLENROCK SOUTH & KMD & WY & COMB & VF & 28 & 20 & 31 \\
\hline CLARETON & $\mathrm{KMD}$ & WY & STRAT & VF & 29 & 14 & 31 \\
\hline GAS DRAW & KMD & WY & STRAT & TM, VF & 26 & 12 & 28 \\
\hline FDDLER CREEK & $\mathrm{KOD}$ & WY & STRAT & VF & 27 & 6 & 28 \\
\hline OSAGE & $\mathrm{KMD}$ & WY & STRAT & VF & 27 & 0 & 27 \\
\hline ROCK RTVER & $\mathrm{KMD}$ & WY & STRUC & TM? & 25 & 0 & 25 \\
\hline PLUM BUSH CREEK & $\mathrm{J}$ & $\mathrm{CO}$ & COMB & $\mathrm{CH}$ & 19 & 2 & 19 \\
\hline CLAY BASIN & $\mathbf{K D}$ & UT & STRUC & & 0 & 104 & 18 \\
\hline ROZET & KMD & WY & STRAT & OM & 17 & 4 & 18 \\
\hline SLOSS & $\mathbf{J}$ & NE & COMB & & 17 & 5 & 18 \\
\hline BAXIER BASIN, SOUTH & $\mathbf{K D}$ & WY & COMB & & 0 & 98 & 17 \\
\hline PEORIA & J & $\mathrm{CO}$ & STRAT & VF & 13 & 15 & $\overline{15}$ \\
\hline UTE & $\mathrm{KMD}$ & WY & STRAT & $T M$ & 10 & 23 & 14 \\
\hline MUSH CREEK & $\mathrm{KMD}$ & WY & SIRAT & VF & 13 & 2 & 13 \\
\hline BIG BEAVER & $\mathrm{J}$ & $\mathrm{CO}$ & & & 13 & 2 & 13 \\
\hline YENTER & $\mathrm{J}$ & $\mathrm{CO}$ & & & 9 & 22 & 12 \\
\hline SPRINGEN RANCH & KMD & WY & STRAT & TM-DC & 10 & 11 & 12 \\
\hline SKULL CREEK & KMD & WY & STRAT & VF & 12 & 1 & 12 \\
\hline FLDLER CREEK E UNIT & KAND & WY & STRAT & VF & 11 & 0 & 11 \\
\hline SINGLETON & $\mathrm{J}$ & NE & STRAT & $T M$ & 11 & 2 & 11 \\
\hline ENDERS & 3 & NE & COMB & & 9 & 1 & 9 \\
\hline THIRD CREEK & $\mathrm{J}$ & $\mathrm{CO}$ & STRAT & VF & 4 & 29 & 9 \\
\hline WIIISON RANCH & $\mathrm{J}$ & NE & & & 8 & 3 & 9 \\
\hline SAGE SPRINGS CREER & $\mathrm{KMD}$ & WY & COMB & TM-DC? & 8 & & 8 \\
\hline MOUNT HOPE & $\mathrm{J}$ & $\mathrm{CO}$ & COMB & & 7 & 6 & 8 \\
\hline FERRIS & $\mathrm{KMD}$ & $\mathbf{W Y}$ & STRUC & & 0 & 41 & 7 \\
\hline BAXTER BASIN, NORTH & $\mathrm{KD}$ & WY & $\mathrm{COMB}$ & & & 43 & 7 \\
\hline COLLUMS & KMD & WY & STRAT & $\mathbf{M M}$ & 6 & 7 & 7 \\
\hline HORSE CREEK & $\mathrm{KMD}$ & WY & STRUC & $\mathrm{OM}$ & 7 & & 7 \\
\hline JACINTO & $\mathrm{J}$ & NE & COMB & & 7 & 1 & 7 \\
\hline KMMBALL & $\mathrm{J}$ & NE & STRAT & & 6 & 2 & 7 \\
\hline MOSEBAR & $\mathrm{KMD}$ & WY & STRAT & & 5 & 8 & 7 \\
\hline LOST SOLDIER & $\mathrm{KMD}$ & WY & STRUC & VF & 7 & & 7 \\
\hline WHIIETAII & KMD & WY & STRAT & $\mathbf{T M}$ & 6 & 2 & 6 \\
\hline LEWIS CREEK & $\mathrm{J}$ & $\mathrm{CO}$ & & & 5 & 3 & 6 \\
\hline WERTZ & $\mathrm{KMD}$ & WY & STRUC & VF? & & 34 & 6 \\
\hline OLSEN & $\mathrm{J}$ & NE & STRAT & & 6 & 0 & 6 \\
\hline MIIL GIIETIE & $\mathrm{KMD}$ & WX & STRAT & $\mathrm{TM}$ & 4 & 10 & 6 \\
\hline STEINLE RANCH & $\mathrm{KMD}$ & WY & STRAT & $\mathrm{TM}$ & 4 & 9 & 6 \\
\hline
\end{tabular}

Sorted by decreasing MMBOE cumulative as of 1988

$\mathrm{KMD}=$ Muddy Sandstone, J = J Sandstone, $\mathrm{KD}=$ Dakota (age equivalent)

STRAT = stratigraphic, comb $=$ combination of stratigraphic and structure, STRUC $=$ structural

$\mathrm{OM}=$ older marine, $\mathrm{TM}=$ transgressive marine, $\mathrm{VF}=$ valley fill, $\mathrm{CH}=$ channel of unknown type, $\mathrm{DC}=$ distributary channel.

No value indicates environment unkown by the authors. 


\section{VALLEY FILL \&}

CHANNELS

359 MILLION BOE

(74 RESERVOIRS)

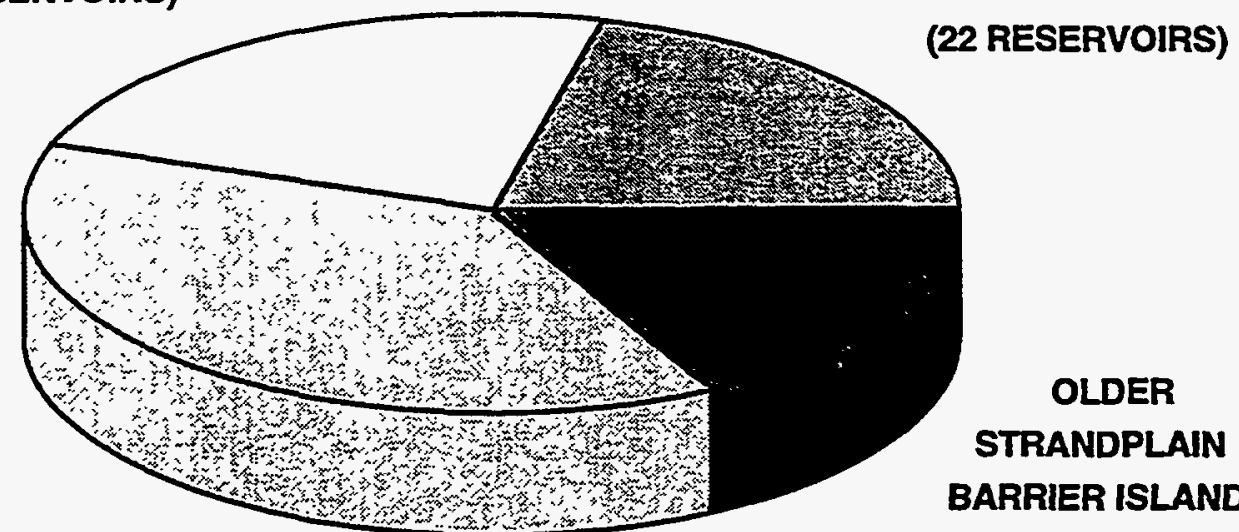

UNKNOWN
TRANSGRESSIVE

STRANDPLAIN

BARRIER ISLAND

315 MILLION BOE

(22 RESERVOIRS)

TOTAL MUDDY AND EQUIVALENT $=1,527$ MILLION BOE

Figure 6.6 Cumulative Production from Different Muddy Sandstone Depositional Environments (Modified from: Dolson et al., 1991, reprinted by permission)

Cumulative production and reservoir properties for representative fields are presented in Table 6.4. Production can be related to the various Muddy Sandstone reservoir types (Figure 6.6).

Valley fill and fluvial channel reservoirs have produced at least 359 million barrels of oilequivalent (MMBOE), transgressive marine reservoirs have produced another $315 \mathrm{MMBOE}$, and older marine reservoirs have produced more than 268 MMBOE (Dolsen et al., 1991).

Reservoirs in the transgressive marine sandstones have the best per field reserves with cumulative production of 10-25 MMBOE common (Figure 6.6). Hilight field exhibits the largest cumulative production with $74 \mathrm{MMBO}$ and 227 billion cubic feet produced since its discovery in 1969. Adena field (Denver Basin) has similar production (Mygdal, 1963). Most of the larger transgressive marine fields overlie major valley systems, indicating the importance of fluvial sand input during transgression for thick reservoir development. The higher per-field reserves are attributed to a more homogeneous reservoir, particularly when compared to highly variable valley-fill traps.

In general, the older marine reservoirs are lower in productivity, where $268 \mathrm{MMBOE}$ has been produced out of 14 fields. Only 3 of the 14 fields contain major reserves. Reservoir destruction due to capping paleosol formation may contribute to the low reserves (Weimer et al., 1986; Odland et al., 1988). Older marine reservoirs commonly have a sheet geometry with few traps available.

An exception to the low productivity of older marine reservoirs is Bell Creek field. Weimer (1985) attributed the bulk of the more than 130 MMBOE production to exceptionally porous and permeable sandstones preserved under a major unconformity. 
Valley fill and channel reservoirs are most numerous but typically have small per-field reserves. The two largest valley-fill fields are Grieve with $41 \mathrm{MMBOE}$ (Mitchell, 1976) in the Wind River Basin and the Recluse field with $38 \mathrm{MMBOE}$. The Clareton trend contains over $60 \mathrm{MMBOE}$ in numerous pools.

The $585 \mathrm{MMBOE}$ of reserves not attributed to specific fields in the discussion above is distributed through hundreds of small pools whose individual cumulative productions have not exceeded 2 MMBOE.

\subsubsection{Improved Oil Recovery Projects (Major Plays)}

Significant IOR activity has occurred in the Muddy and D-J Plays. Polymer and surfactant processes have received attention in the Muddy Play and in a Frontier formation reservoir interpreted as of possible strandplain/barrier island origin (Szpakiewicz et al., 1987). Polymer, gel polymer, and in situ combustion processes have been applied in the D-J Plays. Only one polymer project has been reported in New Mexico's Gallup Barrier Island Play. In the northern Rockies, $\mathrm{CO}_{2}$ and gel polymer applications have received attention.

\subsubsection{Muddy and Frontier Plays}

Polymer and micellar-polymer processes have been the predominant processes used in the Muddy Plays. Polymer projects have been conducted in the Fiddler Creek, Hilight, and Ute fields listed as Class 4 reservoirs in the TORIS database. Table 6.5 summarizes data from the Enhanced Oil Recovery Project Database (Pautz et al., 1992) for these projects. Reservoir depth ranges from 4,400 feet in the Fiddler Creek field to 9,600 feet in the Hilight field. Bottom-hole temperature in the Hilight field exceeds that normally recommended for polymers. Oil gravities are in the $40^{\circ}$ API range and reservoirs are thin rather than massive. Note that Dolson et al. (1991) consider the Fiddler Creek to be a valley fill environment (Table 6.4) rather than strandplain/barrier island.

\begin{tabular}{|c|c|c|c|}
\hline \multicolumn{4}{|c|}{ 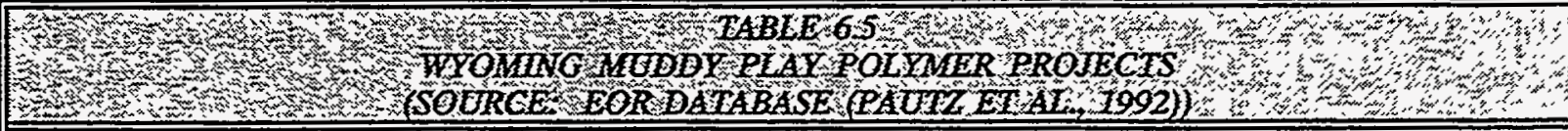 } \\
\hline PARAMETER & FIDDLER CREEK & HILIGHT & UTE \\
\hline $\begin{array}{l}\text { LOCATION (COUNTY, } \\
\text { STATE) }\end{array}$ & WESTERN, WY & CAMPBELL, WY & CAMPBELL, WY \\
\hline RESERVOIR & NEWCASTLE & MUDDY & MUDDY \\
\hline DATE STARTED & 1985 & 1975 & - \\
\hline SIZE, ACRES & 660 & 120 & 4,683 \\
\hline NO. OF WELLS & 14 & 9 & - \\
\hline DEPTH, FT & 4,400 & 9,600 & 6,386 \\
\hline TEMPERATURE, ${ }^{\circ} \mathrm{F}$ & 120 & 234 & - \\
\hline GRAVITY, ${ }^{\circ}$ API & 40 & 40 & - \\
\hline POROSITY, \% & 20 & 17 & 17 \\
\hline NET PAY, FT & 6 & - & 18 \\
\hline GROSS PAY, FT & - & - & 66 \\
\hline
\end{tabular}


Historical activity also includes micellar-polymer or surfactant projects in the Bell Creek and Big Muddy (Frontier) fields. These projects were conducted in conjunction with past Department of Energy field demonstration or tertiary incentive programs. Although none of these projects are currently active, their results provide valuable geological and engineering insight concerning the Rocky Mountain Class 4 resource.

\section{Bell Creek}

Bell Creek field was discovered in 1967 and was subsequently divided into geologically based units for the purposes of waterflooding. Waterflooding began in Unit $A$, a unit in the northern part of the field, in 1970 using an edge-line drive along the western edge of the Unit. Process screening indicated Union Oil Company's Uniflood ${ }^{\text {Tx }}$ micellar-polymer process would be an effective tertiary process. A confined, 40-acre pilot in the northern part of Unit A was selected for the pilot.

Before chemical injection, the pilot area was waterflooded for nearly 2 years resulting in oil saturations being near waterflood residual. The chemical injection sequence included an alkaline silicate preflush to control clays, the Uniflood ${ }^{\text {th }}$ micellar slug, followed by a polymer mobility buffer. Micellar slug injection was completed by October 1979. Performance was worse than anticipated due to unexpected permeability variations, directional permeability, and previously unknown flow barriers (Holm, 1982). Another analysis (Fanchi and Dauben, 1982) indicated that sulfonate equivalent weight and water salinity in the chemical slug also contributed to the poor performance.

A second Uniflood ${ }^{\text {th }}$ micellar-polymer project was started in 1981 in Bell Creek Unit A. Project location was about 3.5 miles south of the first pilot in an area that geological and engineering investigation had established as being more homogeneous (Honarpour et al., 1989). Results were more favorable, and cumulative tertiary oil production from the 179-acre project area was 1.37 million barrels of oil through August 1987.

An extensive, integrated geological and engineering analysis of the Bell Creek Unit A primary, secondary, and tertiary production from the two tertiary pilots was supported by the DOE (Sharma et al., 1990; Honarpour et al., 1989; Jackson et al., 1991; Cheng and Sharma, 1991). Besides demonstrating integrated reservoir management techniques, this work defined the mechanisms that control production in Bell Creek Unit A. Sharma et al. (1990) identified five factors affecting oil production. These five factors are: (1) the stratigraphic relation of barrier sandstones to valley-fill; (2) the development and architecture of barrier island facies; (3) the depth and width of erosional cuts into the barrier island and the nature of infilling material; (4) clay content; and (5) local faulting with associated fluid flow alteration.

The DOE-funded work in Bell Creek field culminated in guidelines for developing an integrated reservoir model (Jackson et al., 1991). These guidelines establish that different levels of model detail are required for primary, secondary, and improved oil recovery (IOR) operations. For primary, only a basic geological model is required. For secondary operations, the model must be expanded to a permeability model including external boundaries, lateral variations in pay thickness, and dip-strike considerations. For IOR operations, the model must be further expanded to a flow-unit model identifying directional permeability trends, spatial variations in clay content, and faults distorting flow paths. 
Experience at Bell Creek indicates the strong need for a technique to identify heterogeneities affecting fluid flow prior to starting IOR projects. To this end, Cheng and Sharma (1991) developed a differential oil-in-place (DOIP) technique for identifying heterogeneities within a field using data available prior to IOR operations. Results were validated in the Bell Creek project area by comparing DOIP values with known heterogeneities.

\section{Big Muddy Field}

Conoco conducted two micellar-polymer pilots in the Second Wall Creek (Frontier formation) reservoir in the Big Muddy field. An initial one-acre pilot led to a 90-acre, DOE cost-shared pilot. Preflush injection began in February 1980, followed by micellar slug injection in January 1981, followed by polymer drive bank injection in August 1982. Polymer injection was discontinued in 1985 due to injectivity problems and deteriorating production performance.

Project incremental recovery through May 1987 was 290,000 barrels with ultimate project recovery estimated at 390,000 barrels (Cole, 1988). Tertiary oil recovery was estimated at 219,000 barrels (Borah and Gregory, 1988) with recovery being only a fourth of original predictions. Independent project reviews (Cole, 1988 and Borah and Gregory, 1988) cited lack of fluid containment as the primary cause of poor performance. Poor containment resulted from a natural fracture system, fracturing resulting from injection overpressuring, and completion quality in old or abandoned wells. Facilities design practices resolved the oil treating problems often experienced in micellar-polymer projects.

\subsubsection{Gallup Barrier Island Play}

Only one IOR project has been conducted in the Gallup Barrier Island Play, an Arco polymer project in the Gallup formation in the Horseshoe field. This project, which began in 1983, is relatively small (Pautz et al; 1992) and little information is available.

\subsubsection{DJ (Dakota) Plays}

As with the Muddy and Gallup Barrier Island Plays, polymer methods have been the primary IOR processes applied in this group of plays. Polymer projects have been conducted in the Sleepy Hollow Reagan Sand Unit (DJ Cambridge Arch) in Nebraska and in the Hospah sands in the Hospah and Hospah South fields (Dakota barrier islands) in New Mexico. A 1-year-long in situ combustion project was also conducted in Hospah South field.

Amoco started polymer flooding the Reagan sand in the Sleepy Hollow Reagan Unit in 1985. Waterflood efficiency had been limited by an unfavorable mobility ratio with the $31^{\circ} \mathrm{API}, 24 \mathrm{cP}$ viscosity crude. Conditions favoring polymer application included (1) high injectivity, (2) high oil saturation, and (3) a readily available source of fresh water (Christopher, Clark, and Gibson, 1988). Oil production increased within 1 year of polymer injection and the producing water-oil ratio dropped significantly. Estimated incremental recovery through October 1987 was 621,000 barrels of oil. 
Operating problems were experienced with producer plugging and corrosion once polymer broke through in producers. This project is considered a technical and economic success.

Tenneco conducted an in situ combustion pilot in the Lower Hospah sand in the South Hospah field in 1980-1981. In this field, the Lower Hospah (Gallup) sand is a clean, blanket sand about 100 feet thick. Crude gravity is $26^{\circ}$ API. Secondary recovery activities prior to the in situ combustion pilot included cyclic gas-water injection followed by waterflooding. Primary and secondary recovery predictions of only $34 \%$ of the OOIP prompted IOR interest. Poor performance caused the project to be terminated within 1 year. Post-project analysis indicated the project failed because the combustion front propagated through the transition/water zone underlying the oil layer (Struna and Poettman, 1986).

Polymer methods have been applied in the Hospah area with more encouraging results reported. Tesoro started separate polymer projects in the Hospah and Hospah South fields in 1983. Crude gravity in these projects was $24^{\circ} \mathrm{API}$. Results in the Upper Hospah sand in the Hospah field were considered encouraging (Pautz et al., 1992).

Gel polymers have been applied in the Dakota formation in the Sage Spring Creek Unit Ain the Sage Spring Creek field. Although this reservoir is not listed in the TORIS database, prior work (Jackson, 1986 and Mallory, 1972) considered the reservoir to be of the strandplain/barrier island type. At Sage Spring Creek, the Dakota sandstone exhibits a Dykstra-Parsons permeability coefficient of 0.82 and is fractured (Mack and Warren, 1984). In-depth fluid diversion using the sequential aluminum citrate process was implemented during 1978 to improve conformance. Incremental recovery due to the sequential aluminum citrate process was estimated at about 10 barrels of incremental oil per lb of polymer.

Colloidal dispersion gels (see section 6.2.4.2) have been applied in a Dakota well in the East Burke Ranch field. This field offsets the Sage Spring Creek field. Performance was better than that observed in the Sage Spring Creek Unit A project (Mack and Smith, 1994).

\subsubsection{Process Technologies of Regional Interest}

In the northern Rockies, both $\mathrm{CO}_{2}$ and gel polymer processes are of regional interest. $\mathrm{CO}_{2}$ miscible flooding applications are dependent on $\mathrm{CO}_{2}$ supply infrastructure. At present, no Class 4 reservoirs listed in TORIS are undergoing $\mathrm{CO}_{2}$ miscible floods; however, cyclic $\mathrm{CO}_{2}$ stimulation treatments have been performed in some wells completed in Class 4 reservoirs. Gel polymers are frequently applied in the Northern Rockies, including wells completed in Class 4 reservoirs. Recent field results with colloidal dispersion gels and acrylamide-polymer/chromium (III) carboxylate gels are furthering development and application of gel polymer technology.

\subsubsection{Cyclic $\mathrm{CO}_{2}$ Stimulation}

Through the efforts of the Enhanced Oil Recovery Institute at the University of Wyoming, field tests using cyclic $\mathrm{CO}_{2}$ stimulations have been performed during recent years. Not all of the treatments have been in Class 4 reservoirs, but results establish generally applicable process guidelines. 
Although current economics (Branting and Whitman, 1992) do not favor widespread application, the process technology is an area of active interest in Wyoming.

\section{Amoco Experience}

During 1990, Amoco conducted 13 cyclic $\mathrm{CO}_{2}$ stimulation treatments in Wyoming in the Lost Soldier (2), Wertz (5), Beaver Creek (1), Little Buffalo Basin (2), and Salt Creek Light Oil (3) fields (Passmore, 1991). Ongoing $\mathrm{CO}_{2}$ miscible floods provided a ready $\mathrm{CO}_{2}$ source for the Lost Soldier and Wertz tests, while $\mathrm{CO}_{2}$ was trucked to the other fields. Design criteria included creating a $50 \% \mathrm{CO}_{2}$ saturation 150 feet from the wellbore. $\mathrm{CO}_{2}$ was injected over a 1- to 2-week period, followed by a soak period averaging 35 days.

Treatments in Lost Soldier and Wertz fields were conducted at pressures above minimum miscibility pressure. Four of the seven treatments in Lost Soldier and Wertz fields were considered economically successful (Passmore, 1991). In Lost Soldier field, two Cambrian (Class 4 reservoir) wells were stimulated, each with about $40 \mathrm{MMCF}$ of $\mathrm{CO}_{2}$. One well failed due to mechanical reasons, but the successful treatment exhibited a $\mathrm{CO}_{2}$ utilization factor of $6.2 \mathrm{MCF}$ of $\mathrm{CO}_{2}$ per barrel of oil. In Wertz field, four Darwin Madison (Class 4 reservoir) wells were treated with $\mathrm{CO}_{2}$ volumes ranging from 40 to $78 \mathrm{MMCF}$. Two of the four treatments were successful. The average $\mathrm{CO}_{2}$ utilization factor for the successful treatments was $13.4 \mathrm{MCF}$ of $\mathrm{CO}_{2}$ per barrel of oil. Characteristic responses included increased oil production and, due to significantly lower water production, lower total fluid volumes. Submersible pump failures were the primary operating problem.

The three treatments in the Wall Creek reservoir in Salt Creek field were conducted at pressures below minimum miscibility pressure. Treatment volumes ranged from 14 to $36 \mathrm{MMCF}$ of $\mathrm{CO}_{2}$. Two of the three treatments exhibited poor containment with rapid $\mathrm{CO}_{2}$ breakthrough to offset wells. Amoco considered the results encouraging and was planning further, smaller volume treatments to increase containment.

\section{Wyoming Carbonics, Inc. (WCI) Experience}

WCI performed 29 cyclic $\mathrm{CO}_{2}$ treatments during 1990-1991 (Carlisle, 1992). Well selection and treatment guidelines were developed from the experience gained with these treatments. Wells with thief zones or extensive fractures do not make good candidates for treatment. Good initial production potential is more important than current production rate. Other guidelines for equipment, operating practices, and $\mathrm{CO}_{2}$ soak time as a function of reservoir pressure were developed. For low-pressure ( $<400$ psi) reservoirs, shut-in times of only 5 to 8 days are recommended. For moderate-pressure ( 400 to $1,000 \mathrm{psi}$ ) reservoirs, shut-in times from 10 to 14 days are recommended. For high-energy $(1,000$ to $2,400 \mathrm{psi})$ reservoirs, shut-in times from 15 to 30 days are recommended.

\section{Detailed Analysis of Lower Cretaceous Projects}

The University of Wyoming (Smith and Surdam, 1992) analyzed Cretaceous, cyclic $\mathrm{CO}_{2}$ stimulation projects in North Grieve and Beaver Creek fields in the Wind River Basin, Crooks Gap field 
in the Great Divide Basin, Cole Creek field in the Powder River Basin, and Grass Creek field in the Bighorn Basin. Treated formations included the Dakota, Muddy, Cody, and Frontier. Confinement problems were experienced in all but Cole Creek field, a Dakota formation project; however, this project was the only project which experienced scaling problems. Scaling problems were attributed to a combination of a long soak time, abundant calcite in the reservoir, and a large nearwellbore pressure drop.

\subsubsection{Gel Polymer Applications}

Gel polymers have historically been widely applied in the Wyoming/Rocky Mountain region. A portion of these applications have been in Class 4 reservoirs. Gel polymer applications can be applied for either near-wellbore or in-depth fluid diversion. Field results with two recently developed technologies, colloidal dispersion gels and acrylamide-polymer/chromium (III) carboxylate gels have been promising.

In-depth fluid diversion treatments have historically relied upon in situ crosslinking. One approach has been to sequentially inject slugs of polymer and aluminum citrate, the crosslinking agent. Since crosslinking occurs in situ, flexibility and control of this process can be poor. With colloidal dispersion gels, weak gels are formed prior to injection using low polymer and crosslinker concentrations. Since gels are formed prior to injection, the process provides more flexibility and control.

Mack and Smith (1994) documented the results of 29 field projects. Twenty-two of the 29 projects were considered successful with reported chemical costs of $\$ 1$ to $\$ 2$ per barrel of incremental oil. Problems were experienced when projects were started late in waterflood life or when fractures or extreme channeling situations were encountered. Although most treatments were in non-Class 4 Minnelusa formation reservoirs, one application was in a Dakota well in East Burke Ranch field. The East Burke Ranch field offsets the Sage Spring Creek Unit A project where the sequential aluminum citrate injection process was used. Observed chemical costs were less than $\$ 1$ per incremental barrel of oil, and performance was considered better than was observed in the Sage Spring Creek Unit A project.

Promising results have also been experienced with acrylamide-polymer/chromium (III) carboxylate gels. Marathon (Southwell and Posey, 1994) documented the results of 26 injection well treatments performed in 1989-1992. Although the treatments were performed in non-Class 4, fractured Tensleep and Phosphoria reservoirs in the Oregon Basin and Pitchfork fields in Wyoming, results may have future application to Class 4 reservoirs. Unlike conventional gel treatments, many of these treatments were large volume treatments up to 20,000 barrels. Despite the large treatment volumes, overall results were attractive with gross development costs quoted as $\$ 0.99$ per incremental barrel of oil. Sydansk and Moore (1992) referenced even lower costs for long-term results on treatments performed in 1985-1986.

These gel treatments have also been used in a $\mathrm{CO}_{2}$ miscible flood to control conformance problems. Amoco (Borling, 1994) performed ten injection well treatments in their Wertz $\mathrm{CO}_{2}$ flood in southwest Wyoming (non-Class 4 Tensleep reservoir). Amoco reported payout times ranging from 1.1 to 3.7 months. Pattern lives were also extended for up to 2 years. Importantly, the treatments were performed in full compliance with company, state, and federal environmental standards. 


\subsection{References}

Almon, W.R. and D.K. Davies, 1979, Regional diagenetic trends in the Lower Cretaceous Muddy Sandstone, Powder River Basin: Society of Economic Paleontologists and Mineralogists, Special Publication No. 26, p. 379-400.

Borah, M.T. and M.D. Gregory, 1988, A summary of the Big Muddy field low-tension flood demonstration project: SPE 17536 Rocky Mountain Regional Meeting, Casper, Wyoming, p. 499508.

Borling, D.C., 1994, Injection conformance control case histories using gels at the Wertz field $\mathrm{CO}_{2}$ tertiary flood in Wyoming: SPE/DOE 27825 Ninth Symposium on Improved Oil Recovery, Tulsa, Oklahoma, p. 469-482.

Branting, J.K and D.L. Whitman, 1992, The feasibility of using $\mathrm{CO}_{2}$ EOR techniques in the Powder River Basin of Wyoming: SPE 24337 Rocky Mountain Regional Meeting, Casper, Wyoming, p. 271-278.

Burtner, R.L. and M.A. Warner, 1984, Hydrocarbon generation in the Lower Cretaceous Mowry and Skull Creek shales of the northern Rocky Mountains area, in J. Woodward, F.F. Meissner, and J.L. Clayton, eds., Hydrocarbon source rocks of the Greater Rocky Mountain region: Rocky Mountain Association of Geologists Symposium, p. 449-467.

Carlisle, C., 1992, Our first nine months' experience with $\mathrm{CO}_{2}$ cyclic stimulation in Wyoming oil fields (August 1990-April 1991): Proceedings of the Seventh Wyoming Enhanced Oil Recovery Symposium, Laramie, Wyoming, p. 65-78.

Cheng, A.M. and B. Sharma, 1991, Delineation of favorable areas for EOR from differential oil-inplace calculations in Bell Creek field, Montana: SPE 21824 Rocky Mountain Regional Meeting, Denver, Colorado, p. 217-226.

Christopher, C.A., T.J. Clark, and D.H. Gibson, 1988, Performance and operation of a successful polymer flood in the Sleepy Hollow Reagan Unit: SPE/DOE 17395 Enhanced Oil Recovery Symposium, Tulsa, Oklahoma, p. 799-810.

Cole, E.L., 1988, An evaluation of the Big Muddy field low-tension flood demonstration project: Department of Energy Report DOE/BC/10830-0, December, 151 p.

Dolson, J., D. Muller, M.J. Evetts, and J.A. Stein, 1991, Regional paleotopographic trends and production, Muddy Sandstone (Lower Cretaceous) central and northern Rocky Mountains: American Association of Petroleum Geologists Bulletin, vol. 75, No. 3, p. 409-435.

Dolson, J. and K. Nibbelink, 1985, Cretaceous depositional systems, northern D-J (Cheyenne) basin: examples from the Dakota Group and Laramie-Fox Hills formations; in D.L. Macke and E.K. Maughan, eds., Society of Economic Paleontologists and Mineralogists, Rocky Mountain Section Field Trip Guidebook, p. 1-30.

Fanchi, J.R. and D.L. Dauben, 1982, An evaluation of the Bell Creek field micellar-polymer pilot: Department of Energy Report DOE/BC/10033-5, December, p. 42. 
Gustason, E.R., R.A. Ryer, and S.K. Odland, 1986, Unconformities and facies relationships of Muddy Sandstone, northern Powder River Basin, Wyoming and Montana: American Association of Petroleum Geologists Bulletin, vol. 70, No. 8, p. 1042.

Honarpour, M., M.J. Szpakiewicz, B. Sharma, M.M. Chang, R. Schatzinger, S. Jackson, L. Tomutsa, and N. Maerefat, 1989, Integrated reservoir assessment and characterization: Department of Energy Report NIPER-390, May, 336 p.

Holm, L.W., 1982, Design, performance, and evaluation of the Uniflood micellar-polymer process-Bell Creek field: SPE 11196 57th Annual Technical Conference, New Orleans, Louisiana, $29 \mathrm{p}$.

Jackson, S.R., L. Tomutsa, M. Szpakiewicz, M.M. Chang, M.M. Honarpour, and R.A. Schatzinger, 1991, Construction of a reservoir model by integrating geological and engineering information-Bell Creek field, a barrier/strandplain reservoir; in Lake, L.W., H.B. Carroll, Jr., and T.C. Wesson, eds., Reservoir Characterization II, Academic Press, San Diego, California, p. 524 556 of 726.

Jackson, S.R., 1986, Selection of deposystem for heterogeneity research: Department of Energy Report NIPER-153, 19 p.

Kaufmann, E.G., 1977, Upper Cretaceous cyclothems, biotas and environments, Rock Canyon anticline, Pueblo, Colorado: The Mountain Geologist, vol.14, p. 129-152.

Mack, J.C. and J.E. Smith, 1994, In-depth colloidal dispersion gels improve oil recovery efficiency: SPE/DOE 27780 Ninth Symposium on Improved Oil Recovery, Tulsa, Oklahoma, p. 527-539.

Mack, J.C. and J. Warren, 1984, Performance and operation of a crosslinked polymer flood at Sage Spring Creek Unit A, Natrona County, Wyoming: Journal of Petroleum Technology, vol. 36, No. 7, July, p. 1145-1156.

MacKenzie, D.B., 1971, Post-Lytle Dakota Group on the west flank of Denver Basin, Colorado: The Mountain Geologist, vol. 8, p. 91-131.

McGookey, D.P., 1972, Cretaceous System, in W. Mallory, ed., Geologic atlas of the Rocky Mountain region: Rocky Mountain Association of Geologists, Denver, Colorado, p. 198.

Mallory, W.E., ed., 1972, Geologic atlas of the Rocky Mountain region: Rocky Mountain Association of Geologists, Denver, Colorado.

Mitchell, G.C., 1976, Grieve oil field, Wyoming: a Lower Cretaceous estuarine deposit: The Mountain Geologist, vol. 13, p.71-87.

Mygdal, K.A., 1963, Adena, largest field in the Denver Basin, in D.W. Bolyard and P.J. Katich, eds., Geology of the northern D-J Basin and adjacent uplifts: Rocky Mountain Association of Geologists 14th Annual Field Conference Guidebook, p. 222-225.

Odland, S.K. E.R. Gustason, and P.E. Patterson, 1988, Amos Draw field: a diagenetic trap related to an intraformational unconformity in the Muddy Sandstone, Powder River Basin, Wyoming, in R.P. Didrich, M.K. Dyka, and W.R. Miller, eds., Eastern Powder River Basin and Black Hills field conference: Wyoming Geological Association 39th Annual Field Conference Guidebook, p. 147-160. 
Passmore, R., 1991, Amoco's experience with $\mathrm{CO}_{2}$ cyclic stimulation in Wyoming, 1990-91: Proceedings of the Seventh Wyoming Enhanced Oil Recovery Symposium, Laramie, Wyoming, p. 51-63.

Pautz, J.F., C.A. Sellers, C. Nautiyal, and E. Allison, 1992, Enhanced oil recovery projects data base: Department of Energy Report NIPER-583, February, 344 p. plus Appendix D.

Sharma, B., M.M. Honarpour, M.J. Szpakiewicz, and R.A. Schatzinger, 1990, Critical heterogeneities in a barrier island deposit and their influence on various recovery processes: SPE Formation Evaluation, vol. 5, No. 1 March, p. 103-112.

Smith, L.K and R.C. Surdam, 1992, Cyclic $\mathrm{CO}_{2}$ enhanced oil recovery in Wyoming Cretaceous fields: Wyoming Geological Association 43rd Annual Field Conference Guidebook, p.145166.

Southwell, G.P. and S.M. Posey, 1994, Applications and results of acrylamide-polymer/chromium (II) carboxylate gels: SPE/DOE 27779 Ninth Symposium on Improved Oil Recovery, Tulsa, Oklahoma, p. 513-526.

Struna, S.M. and F.H. Poettmann, 1986, In-situ combustion in the Lower Hospah formation, McKinley County, New Mexico: SPE/DOE 14917 Fifth Symposium on Enhanced Oil Recovery, Tulsa, Oklahoma, p. 469-477 plus tables and figures.

Szpakiewicz, M., K. McGee, and B. Sharma, 1987, Geologic problems related to characterization of clastic reservoirs for EOR: SPE Formation Evaluation, vol. 2, No. 4, December, p. 449-460.

Sydansk, R.D. and P.E. Moore, 1992, Gel conformance treatments increase oil production in Wyoming: Oil and Gas Journal, vol. 90, No. 3, January 20, p. 40-45.

Weimer, R.J., 1985, New age interpretation of Bell Creek Sandstone, Powder River Basin, Montana and Wyoming (abs.): American Association of Petroleum Geologists Bulletin, vol. 69, No. 5, p. 870.

Weimer, R.J., J.J. Emme, C.L. Farmer, L.O. Anna, T.L. Davis, and R.L. Kidney, 1982, Tectonic influence on sedimentation, Early Cretaceous east flank, Powder River Basin, Wyoming and South Dakota: Colorado School of Mines Quarterly, vol. 77, No. 4, 61 p.

Weimer, R.J., S.A. Sonneberg, and G.B. Young, 1986, Wattenberg field, Denver Basin, Colorado: in C.W. Spencer and R.F. Mast, eds., Geology of tight gas reservoirs: American Association of Petroleum Geologists Studies in Geology No. 24, p. 143-164. 


\section{CHAPTER 7 \\ IMPROVED OIL RECOVERY CHALLENGES}

Improved oil recovery applications in Class 4 reservoirs face reservoir, process, and regional challenges. For discussion purposes within this report, challenges have been grouped as follows: special technologies, advanced waterflooding, chemical processes, $\mathrm{CO}_{2}$ processes, thermal processes, and challenges by region. Special technologies and advanced waterflooding challenges apply across most geographic regions, while process challenges are often more region-specific.

\subsection{Special Technologies}

Four special technologies are particularly relevant to improved oil recovery applications: reservoir management, infill drilling, computer technologies, and horizontal drilling. Reservoir management is a cross-cutting strategy applicable to any production operation, but it is particularly critical in improved oil recovery applications. Reservoir management has played a major role in all regions where major Class 4 resources exist. Infill drilling, computer technologies, and horizontal drilling can be elements within an improved oil recovery project. Challenges facing technology applications apply to all regions. Within a selected region, certain technologies have greater application than others.

\subsubsection{Reservoir Management}

Thakur (1991) defines reservoir management as "the judicious use of available resources to maximize economic recovery." People, equipment, technology, and money represent available resources. In mature operations, like many in Class 4 reservoirs, each resource must be optimally applied to maintain profitability and maximize economic recovery. External financial pressures for short-term economic performance contribute to the sense of urgency with regards to reservoir management.

Hickman (1993) recognizes reservoir management as a strategy that involves "merging expertise in various technologies." Critical concepts are (1) production operations are total systems, not just reservoirs, and (2) expertise within various disciplines must be effectively merged. The production system consists of the reservoir rock, the reservoir fluids, the wellbores, injected fluids, surface facilities, and, importantly, any person involved in any phase of the operations. Data and inputs from many sources (legal, environmental, accounting, pumpers, foremen, vendors, secretaries, etc.) in addition to engineering and geology must be considered in the systems approach. As these parties interact concerning the reservoir management opportunity, synergy occurs. The resulting interpretations, answers, and recommendations are more creative and insightful than are possible with the traditional discipline-oriented approach.

Although the concept of interdisciplinary teams is straightforward, industry is challenged in the implementation process. Katzenbach and Smith (1993) define a team as "a small number of people with complementary skills who are committed to a common purpose, set of performance goals, and 
approach for which they hold themselves mutually accountable." Teams share leadership roles, encourage open-ended discussion and problem solving, and do real work together. Integrated information systems are essential (Greene and Rees, 1992). The paradigm shift from individual contributions to team accomplishments challenges both management and staff (Greene and Rees, 1992). Management can struggle with releasing control to the team, while staff can struggle with redefined career expectations in the team environment. Team performance is ultimately judged by the success of actions taken in the field.

\subsubsection{Infill Drilling}

In certain areas, infill drilling represents a major improved oil recovery application. Current economic conditions dictate that infill drilling be "smart" infill drilling. Although blanket infill drilling may be profitable in some reservoirs, geological targeting either increases the margin or provides that extra recovery required to make the program economic. Historical applications in Class 4 reservoirs include the Frio Play in Texas (ICF and BEG, 1990) and Deese reservoirs in Oklahoma (Kendall et al., 1992). Furthermore, the drilling and completion operation must incorporate ongoing technology developments, be cost-optimized considering basin-reservoir experience, and must be in compliance with applicable environmental regulations. Despite having drilled wells for years, industry is still challenged with implementing optimally designed drilling programs.

Reservoir characterization efforts provide the foundation for geologically targeted infill drilling. Despite recent improvements in approaches, industry is still challenged to understand and predict spatial variations in the different facies within a reservoir. Experience indicates facies-level analysis and depositional knowledge are required to optimize geological targeting. Team efforts considering engineering, geological, and production data have been technically effective, but industry is challenged with making team results timely and affordable.

\subsubsection{Computer Technologies}

Computer hardware and software are critical for data capture, data management and analysis, and visualization. Maintaining competency with continually developing computer tools represents an ongoing challenge for industry, especially independents. Although Mobil used 3-D seismic and computer-aided exploration software and workstation technology to increase Class 4 production and reserves from Deese intervals in their Countyline Unit in Sho-Vel-Tum field in Oklahoma (Kendall et al., 1992, see section 4.2.4.2), instances of similar applications by independent operators are rare. Independent operators are challenged with staying current with evolving software capabilities, cost of hardware and software, and training. With limited manpower, time for training can represent a critical challenge. 


\subsubsection{Horizontal Drilling}

To date, horizontal drilling applications have not played a role in Class 4 production, either in conventional production or improved oil recovery operations. Oklahoma's primarily multiplesand applications in the Deese are not favorable to horizontal drilling. Fractured (and faulted) reservoirs in the Rocky Mountain region represent a potential application, but spatial variations/ faults challenge the application. Although horizontal well technology has been applied in Class 3 reservoirs in Elk Hills field in California (Gangle et al., 1991), the technology has not been applied in steam operations in Class 4 reservoirs. Although untested, potential applications may exist in selected Gulf Coast Class 4 reservoirs having a certain degree of dip, good vertical permeability, and numerous compartments or fault blocks. In those instances, horizontal applications to minimize coning may be applicable.

\subsection{Advanced Waterflooding}

Polymer flooding, profile modification or conformance improvement treatments, and microbial waterflooding are grouped within advanced waterflooding. Both polymers and gel polymers for conformance improvement have received widespread application in Class 4 reservoirs, especially in Oklahoma and the Rocky Mountain areas. Emerging microbial waterflooding technology may have application in selected reservoirs.

\subsubsection{Polymer Flooding}

Polymer flooding has been widely applied in both Oklahoma and Rocky Mountain Class 4 reservoirs. Polymer usage has widespread appeal in the Rocky Mountain region due to (1) medium gravity and viscosity crudes needing mobility control and (2) favorably low formation water salinities. Polyacrylamide polymers are the polymer of choice in the Rocky Mountain area. Oklahoma applications with higher formation water salinities have favored biopolymers. In both regions, mobility control polymer flooding and crosslinked polymer treatments are often combined.

Polymer flooding has historically been troubled by polymer injectivity and by temperature and salinity limitations. Although one source (NIPER and K\&A, 1991) indicates that polymer advances have improved temperature and salinity limitations up to $250^{\circ} \mathrm{F}$ and $18 \% \mathrm{NaCl}$, practical field applications are more restrictive. Although one guideline (NIPER and K\&A, 1991) indicates that reservoir permeability should exceed $100 \mathrm{mD}$ to prevent injectivity problems, permeabilities in several of the Oklahoma and Rocky Mountain Class 4 projects average less than $100 \mathrm{mD}$. Pilot injectivity testing is considered an essential element of polymer flood design.

Shear, oxidative, and bacterial degradation problems experienced in early polymer projects can be resolved if known operating practices are followed. An area of challenge continues to be developing more environmentally acceptable biocides.

In most U.S. polymer projects, polymer flooding is not started until late in field life. European polymer projects, which generally apply polymers early in the project life, report significantly higher recoveries than U.S. projects (NIPER and K\&A, 1991). Higher recoveries in European 
projects can be attributed to (1) higher permeabilities (1 to 5 Darcies) or (2) starting projects sooner. Further research is needed to define the factors contributing to Europe's observed higher recoveries and to assess potential recovery impacts of modifying U.S. practices.

NIPER and K\&A (1991) indicate that developing reservoir-specific injection protocols represents a continuing research need. The injection protocol concept includes using different polymers in different slugs plus designing polymer concentration, slug sequence, and slug size to optimize flood economic performance.

\subsubsection{Profile Modification (Gel Polymers)}

Conformance improvement or gel polymer treatments play a major improved oil recovery role in two of the previously discussed Class 4 play areas, Oklahoma and the Rocky Mountain region. As current economic conditions impede other improved oil recovery options, gel polymers may soon play a more important role. Gel polymer applications face several key challenges: (1) correctly identifying the reservoir problem, (2) selecting the proper gel system, (3) tailoring treatment design to the individual well, and (4) properly applying the treatment in the field.

Considering the scope of these challenges, it is no surprise that historical success rates with crosslinked polymer treatments have been poor (Mody et al., 1988). According to Mody and Dabbous (1989), more than two-thirds of treatment failures could be attributed to improper application. Recent industry effort in documenting successes and failures and developing specific application guidelines for different gel polymer systems (Smith, 1994; Southwell and Posey, 1994) are a major step forward in addressing design aspects of gel polymers.

Field application is critical to gel polymer success. Mody et al. (1988) indicated that most gel polymer failures are caused by: (1) improper selection of candidate wells, (2) lack of knowledge of wellbore integrity, (3) lack of adequate preparation of the wellbore prior to job, (4) improper placement of the gel polymer within the wellbore, (5) limited time allotted to implement the treatment, and (6) understanding the injection profile prior to and after the treatment. Of these factors, all may properly be considered to fall within the realm of comprehensive reservoir management practices. Field experience confirms the importance of the comprehensive reservoir management approach.

Gel polymer applications have higher environmental challenges than other improved oil recovery processes. Challenges include human exposure to chemicals during handling and disposal of excess gel polymer if treatments must be prematurely stopped. Although concerns are most prevalent with the conventional chromium redox system, each gel polymer system has its unique environmental challenges. Industry must continue to address safety and environmental issues of current systems while searching for more benign formulations.

\subsubsection{Microbial Waterflooding}

Microbial applications include well stimulation, wellbore cleanup, and microbial waterflooding (permeability modification and enhanced waterflooding). A combination of mechanisms has been proposed for beneficial microbial effects. These mechanisms include surfactant generation, 
wettability alterations, gaseous by-products $\left(\mathrm{CO}_{2}, \mathrm{~N}_{2}, \mathrm{H}_{2}\right.$, and $\left.\mathrm{CH}_{4}\right)$, and plugging. From a costrecovery standpoint, the microbial processes are like gel polymers in that they are low-cost, lower recovery processes. Wellbore cleanup and stimulation represent the most frequently used current applications. Unlike gel polymers, the microbial processes are not widely accepted and applied in the field.

Bryant (1990) proposed the following screening criteria for microbial application: (1) injected and connate water salinities less than $100,000 \mathrm{ppm},(2)$ permeability greater than $75 \mathrm{mD}$, and (3) depth less than 6,800 feet corresponding to a temperature limitation of about $170^{\circ} \mathrm{F}$.

Widespread application of microbial technology awaits (1) favorable economic results from well-documented, larger-scale field projects and (2) increased reliability and predictability. Identified near-term research needs include (1) field testing performance in reservoirs with higher initial oil saturation, (2) development of lower cost, readily available nutrients, and (3) additional development of profile modification and well stimulation methods (NIPER and K\&AA, 1991).

\subsection{Chemical Processes}

Alkaline and surfactant (micellar-polymer) processes are chemical processes which have not been widely applied in Class 4 reservoirs. Mitchell Energy conducted two separate heavy oil alkaline projects in the Subclarksville reservoir in Alba field in the Cretaceous, Salt-Related Play in Texas (see section 3.4.4.2). Micellar-polymer projects have been conducted in Muddy reservoirs in Bell Creek and Big Muddy fields in Montana and Wyoming (see section 6.2.3.1) and in the Hoffman field (Dougherty sand) in Texas's Jackson play (see section 3.3.4). At present, no micellar-polymer projects are active within Class 4 reservoirs listed in the TORIS database.

\subsubsection{Alkaline Processes}

Past alkaline floods often experienced poor mobility control, high alkaline consumption rates, and severe scale problems. Experience has shown that polymers can control mobility problems, and low $\mathrm{pH}$ alkaline agents like sodium bicarbonate can reduce alkaline consumption rates and reduce scaling. Although alkaline floods have been typically perceived as applying to low-gravity, high-acid crudes, research indicates low-acid oils can also respond favorably (Lorenz, 1988). Combinations of lower $\mathrm{pH}$ alkalis and surfactants can be more effective in reducing interfacial tension and recovering more oil than either alkalis or surfactants alone. This knowledge has fostered increased interest in the alkaline process, but significant challenges remain. Further research is needed to better understand mechanisms and to develop effective injection strategies. Additionally, economic potential must be demonstrated in well-documented field pilot tests.

\subsubsection{Micellar-Polymer (Surfactant)}

Although the micellar-polymer process can recover significant oil, past results have been unpredictable. Pope (1993) evaluated the economics of micellar-polymer flooding using different scenarios. Even with high efficiency from improved synthetic surfactants (chemical cost about $\$ 5$ 
per incremental barrel) and a $\$ 20$ per barrel oil price, front-end costs still make the process unattractive.

In addition to cost, Pope offered eight other reasons why the micellar-polymer process is not considered commercial. These reasons included negative industry perceptions, high risk, required high expertise levels to design and operate, and high sensitivity to reservoir characteristics. Challenges include (1) continuing development of lower cost, effective surfactants and (2) process improvements which would accelerate recovery or decrease front-end investments. Pope recognized the potential for recovery acceleration using horizontal wells.

\section{4 $\mathrm{CO}_{2}$ Processes}

Both miscible and cyclic $\mathrm{CO}_{2}$ stimulation processes have been tested in Class 4 reservoirs. Miscible tests in Texas's Frio Play (see section 3.2.4) were encouraging but suspected supply limitations have precluded further commercial applications. A small $\mathrm{CO}_{2}$ pilot has also been conducted in the Pittsburg Field in Texas's Cretaceous, Salt-Related Play (see section 3.4.4.5). Cyclic $\mathrm{CO}_{2}$ stimulation treatments are being tested at various locations throughout Wyoming (see section 6.2.4.1).

NIPER and K\&A's research.needs analysis (1991) identified two major technical challenges facing $\mathrm{CO}_{2}$ flooding: mobility control and predictability. Research efforts with foams, surfactants, gas viscosifiers, and gel polymers are active. Experience in field projects indicates that corrosion and other operating challenges can be managed with proper design and execution.

A recent analysis of field projects indicates progress is being made regarding predictability, at least from a reservoir economic screening standpoint. Flanders et al. (1993) evaluated the economics of $\mathrm{CO}_{2}$ floods in small-to-medium size fields using characteristic production responses observed in field projects. According to their analysis, production response curves were quite similar even in vastly different projects. Actual cost data were examined to develop minimum, maximum, and probable development and operating costs for the economic analysis. Economic conditions assumed that the $\mathrm{CO}_{2}$ supply and delivery infrastructure, the single biggest factor affecting economic viability (NIPER and K\&A, 1991), was already in place.

Sensitivities to $\mathrm{CO}_{2}$ cost, tax incentives, depth, pore volume ( $\left.\emptyset \mathrm{Ah}\right)$ and operating costs were evaluated. Their analysis indicated that $15 \%$ rates of return could be achieved with $\mathrm{CO}_{2}$ costs in the $\$ 0.75$ to $\$ 0.85$ per MCF range. Economic viability was determined to be highly dependent on field-specific start-up costs. Reservoir management (i.e., proper design, implementation, and surveillance) was considered critical to project viability. In West Texas, Amoco considers real-time monitoring and injection adjustment to be critical to the tertiary reservoir management program (Merchant and Thakur, 1993).

Since $\mathrm{CO}_{2}$ viability is dependent on the $\mathrm{CO}_{2}$ source and supply infrastructure, the greatest potential for $\mathrm{CO}_{2}$ applications is forseen in the northern Rocky Mountain region. Results from miscible $\mathrm{CO}_{2}$ floods and cyclic stimulation treatments are stimulating demand, and if Brock and Bryan's perception (1989) that the Rocky Mountain supply infrastructure will expand to meet demand as it has in the Permian Basin is correct, long-term potential for $\mathrm{CO}_{2}$ projects looks promising. 


\subsection{Thermal Processes}

Nearly all of California's Class 4 production comes from steam projects. Steam projects have also been tried in Texas, Oklahoma, and the Rocky Mountain areas. Although in situ combustion projects have been tried in Class 4 reservoirs, project results have inhibited further applications. Where either process meets screening guidelines, operators prefer steam over in situ combustion because steam projects exhibit faster response, require less front-end investment, experience fewer operational problems, are less complex, and staff do not need to be as experienced.

\subsubsection{Steam Applications}

Steam applications face two major challenges: environmental restrictions and high operating costs. Reservoir challenges include injection profile and conformance control. Despite these challenges, existing operations can remain profitable when effective reservoir management practices establish tight operational control.

Although continued operations in California's large steam projects will provide most of the Class 4 steam production, expansion of steam processes may be possible. Encouraging projects have been or are being conducted in the Carrizo sand in Texas's Cretaceous Salt-Related Play (see section 3.4.4.4) and in the 4th Deese sand in Oklahoma's southern Oklahoma Desmoinesian (Pennsylvanian) Play (see section 4.2.4.3). The unconsolidated nature of the sand in both areas favors steam applications.

\subsubsection{In Situ Combustion}

In situ combustion applications are plagued by operator perceptions from early projects. These early projects often experienced (1) unanticipated geological heterogeneities affecting fluid flow, (2) severe operating problems, and (3) safety problems associated with injecting air or oxygen. These factors caused most early projects to be economically unattractive. Despite these early failures, the process is still considered a viable recovery process (Sarathi and Olsen, 1993). Advanced reservoir characterization methodologies should minimize the likelihood of unanticipated reservoir heterogeneities. The few, recent in situ combustion projects have demonstrated that operating problems and safety concerns can be resolved. Reservoir management practices should help maintain the tight cost control required to keep projects profitable.

Amajor challenge to realizing in situ combustion's potential is capturing the expertise of early pioneers in the process. Technology must be effectively transferred to today's engineers through guidebooks and interaction with early pioneers. Old perceptions about in situ combustion will change only as economic viability using modern technologies is demonstrated in well-documented field tests. With demonstrated economic viability, the in situ combustion process appears applicable to several Class 4 reservoirs. 


\subsection{Regional Challenges}

Numerous improved oil recovery projects have been conducted in Class 4 reservoirs over the years. Projects, usually of several different types, have been conducted in all geographic regions containing a significant volume of remaining-oil-in-place. Despite widespread attempts, the impacts of these projects on regional production and improved oil recovery activity levels varies considerably by region. In retaining access to the Class 4 resource, the country is challenged with (1) increasing contributions from improved oil recovery in areas where projects already make an impact and (2) with expanding improved oil recovery applications to reservoirs and regions not currently being impacted.

In Texas, improved oil recovery applications have not impacted production levels. Reservoir management and strategic infill drilling have received most attention in the Frio Strandplain Play. Although results from miscible $\mathrm{CO}_{2}$ projects in the Frio Strandplain Play were promising, suspected supply limitations have limited subsequent applications. In the Jackson Barrier/Strandplain Play, polymer and thermal processes have been the dominant processes in the past, but IOR activity is not impacting current production. Although polymer, alkaline-polymer, in situ combustion, steam and $\mathrm{CO}_{2}$ miscible processes have been employed in the Cretaceous, Salt-Related Play, none of the projects have led to widespread application. Operators are challenged to apply evolving technology and establish IOR projects which will impact production from Texas Class 4 reservoirs.

In Oklahoma, polymer and gel polymer applications produce significant oil in the Pennsylvanian Deese interval sandstones in the southern Oklahoma Desmoinesian and Missourian Plays. As in California, experience indicates that reservoir management is the key to (1) maintaining current operations and (2) developing new potential in these projects. Few improved oil recovery projects have been conducted in other Oklahoma Class 4 reservoirs. These projects, even when successful, have not led to widespread application of improved oil recovery processes in formations other than the Deese. Operators are challenged to expand improved oil recovery activity into these other Class 4 reservoirs in Oklahoma.

In California, significant oil production is realized from steam projects. Further impacts in California depend upon maintaining profitability of existing projects. Cost-effective reservoir management techniques are essential to maintaining profitability.

In the Rocky Mountain region, polymer, gel polymer, and $\mathrm{CO}_{2}$ processes offer potential in Class 4 reservoirs. Polymers have impacted production, and contributions from gel polymer applications can be expected to increase because (1) improved application guidelines are evolving from efforts to document both successes and failures of field treatments and (2) the technology remains economically attractive at moderate, $\$ 12$ to $\$ 15$ oil prices. Future contributions from $\mathrm{CO}_{2}$ depend on development of the $\mathrm{CO}_{2}$ supply infrastructure.

\subsection{References}

Brock, W.R. and L.A. Bryan, 1989, Summary results of $\mathrm{CO}_{2}$ EOR field tests, 1972-1987: SPE 18977 Joint Rocky Mountain Regional/Low Permeability Reservoirs Symposium, Denver, Colorado, p. 499-508. 
Bryant, R.S., 1990, Screening criteria for microbial EOR processes: Department of Energy Report NIPER-478, December, $17 \mathrm{p}$.

Flanders, W.A., R.A. McGinnis, and A.G. Shatto, 1993, $\mathrm{CO}_{2}$ EOR economics for small-to-medium-size fields: SPE 26391 68th Annual Technical Conference, Houston, Texas, p. 87-100.

Gangle, F.J., K.L. Schultz, and G.S. McJannet, 1991, Horizontal wells in a thick steeply dipping reservoir at NPR-1, Elk Hills, Kern County, CA: SPE 21792 California Regional Meeting, Long Beach, California, p. 389-401.

Greene, J.F. and G.D. Rees, 1992, Work teams help independents make best use of technology: Oil and Gas Journal, vol. 90, No. 42, October 19, p. 49-53.

Hickman, T.S., 1993, A rationale for reservoir management economics: SPE 26411 68th Annual Technical Conference, Houston, Texas, p. 101-107.

ICF and BEG (University of Texas at Austin, Bureau of Economic Geology), 1990, An assessment of the reserve growth potential of the Frio Barrier-Strandplain Play in Texas: Department of Energy Report DOE/BC/14000-6, August, 128 p.

Katzenbach, J.R. and D.K. Smith, 1993, The discipline of teams: Harvard Business Review, vol. 71, no. 2, March-April, p. 111-120.

Kendall, J., G. Killberg, L. Zambrano, and J.E. Valusek, 1992, New technologies aid multidisciplinary success in 80-year-old field: Petroleum Engineer International, December, vol. 64, No. 12, p. 14-18.

Lorenz, P.B., 1988, Combination alkaline-surfactant flooding: a state-of-the-art review: Department of Energy Report NIPER-349, October, 29 p.

Merchant, D.H. and S.C. Thakur, 1993, Reservoir management in tertiary $\mathrm{CO}_{2}$ floods: SPE 26624 68th Annual Technical Conference, Houston, Texas, p. 155-169.

Mody, B.G. and M.K. Dabbous, 1989, Reservoir sweep improvement with cross-linked polymer treatments: SPE 17948 Middle East Oil Conference, Manama, Bahrain, 13 p.

Mody, B.G., R.S. McKitrick, and D. Shahsavari, 1988, Proper application of crosslinked polymer decreases operating costs: SPE 17288 Permian Basin Oil and Gas Recovery Conference, Midland, Texas, p. 205-211.

NIPER and K\&A, 1991, Research needs to maximize economic producibility of the domestic oil resource: Department of Energy Report NIPER-527, July 29, 521 p.

Pope, G.A., 1993, Observations about surfactant flooding and future implications: in NIPER-DOE Chemical EOR Workshop: Department of Energy Report NIPER-698, August, p. 24-29.

Sarathi, P.S. and D.K. Olsen, 1993, Status report, thermal processes for heavy oil recovery: Department of Energy Report NIPER-275, December, 16 p.

Smith, J.E., 1994, Closing the lab-field gap: a look at near-wellbore flow regimes and performance of 57 field projects: SPE/DOE 27774 Ninth Symposium on Improved Oil Recovery, Tulsa, Oklahoma, p. 445-459. 
Southwell, G.P. and S.M. Posey, 1994, Applications and results of acrylamide-polymer/chromium (III) carboxylate gels: SPE/DOE 27779 Ninth Symposium on Improved Oil Recovery, Tulsa, Oklahoma, p. 513-526.

Thakur, G.C., 1991, Waterflood surveillance techniques - a reservoir management approach: Journal of Petroleum Technology, vol. 43, No. 10, October, p. 1180-1188. 


\section{CHAPTER 8 FUTURE IMPROVED RECOVERY POTENTIAL FOR TORIS CLASS 4 RESERVOIRS}

At the projected termination of current production operations in the TORIS Class 4 reservoirs, an estimated 19.1 billion barrels of oil will remain in the ground (Refer to Chapter 2 and Figure 2.1). This remaining oil-in-place volume is the target for the future application of improved oil recovery technologies. Nearly $35 \%$ of this resource, or 6.7 billion barrels, is estimated to be unrecovered mobile oil, the target for advanced secondary recovery technologies (ASR). The ASR technologies considered in this analysis include infill drilling, polymer flooding, or profile modification. The remainder of the unrecovered oil resource, 12.4 billion barrels, is considered to be immobile or residual oil, the target for enhanced oil recovery processes (EOR). The EOR technologies considered in this analysis include chemical flooding (alkaline and surfactant), miscible $\mathrm{CO}_{2}$ injection, steam injection, and in situ combustion processes. This chapter discusses the methodology used in the assessment of the future improved oil recovery potential for the TORIS Class 4 reservoirs, and includes a detailed discussion of the predicted recovery potential by process, the portion of this potential that is at risk of abandonment, and the impact of the future application of recovery technologies in the regions discussed in Chapters 3-6.

The future improved oil recovery potential for the TORIS Class 4 reservoirs was estimated to be between 1.0 and 4.3 billion barrels, depending on oil price and the level of technology advancement. The analysis indicated that the majority of this potential could be realized through the future application of infill drilling (alone and in combination with polymer flooding and profile modification), chemical flooding (surfactant and polymer), and thermal processes. The majority of this potential is in Texas, Oklahoma, California and the Rocky Mountains. Approximately two-thirds of this future potential is at risk of abandonment by the year 2000, which emphasizes the urgent need for the development and implementation of economical improved oil recovery processes in Class 4 reservoirs.

\subsection{Improved Oil Recovery Potential Prediction Methodology}

The recovery potential which could result from the future application of improved recovery technologies in the Class 4 reservoirs included in the TORIS database was estimated using the TORIS predictive and economic models. The TORIS database and predictive models were originally developed by the National Petroleum Council (1984) and are maintained and updated by the DOE Bartlesville Project Office. TORIS is used to analyze the recovery potential for various improved oil recovery processes on a reservoir-by-reservoir basis using the average reservoir parameters and historical recovery data in the database and the individual process predictive models, as discussed below.

The TORIS reservoir database contains the average geologic and reservoir parameters for over 2,500 reservoirs in the country. The database contains volumetric original oil-in-place values for each reservoir plus the historical production and injection data. The ultimate recovery that will result from the continued operation of each reservoir is established using decline curve models and 
then the target remaining mobile and immobile oil-in-place volumes are calculated. The decline curve analysis is also utilized to determine the projected reservoir abandonment dates with respect to the timing of future improved recovery projects.

The reservoir parameters contained in the database are screened by the TORIS system to determine the recovery processes that are viable for implementation in each reservoir. The screening criteria used by TORIS for the implemented and advanced technology cases are shown in Table 8.1 and Table 8.2, respectively. The enhanced oil recovery screening criteria are those established by the 1984 NPC study. Screening criteria for advanced secondary recovery processes were developed subsequent to the NPC study. The implemented technology case is considered to be the stateof-the-art case while the advanced technology case assumes a relaxation of some of the screening criteria due to reasonable technological improvements. For example, the profile modification screening criteria in the advanced technology case assumes that the conformance control chemicals are stable at higher reservoir temperature and water salinity than in the implemented technology case. The advanced technology case also assumes some recovery process efficiency improvements, such as decreased chemical retention, increased injectant sweep efficiency, or improved overall process displacement efficiency. See the 1984 NPC study for details on the assumed individual process improvements between the implemented and advanced technology cases and for more details on the predictive models themselves.

The predictive models for each of the viable recovery processes are run using the average reservoir parameters. Results are obtained for both the implemented and advanced technology cases. The resultant injection and production streams are then used as input to the economic models. The economic models consider the capital investments and operating costs required to implement and maintain the individual recovery projects. The economic models examine project economics at various oil prices using West Texas Intermediate as the benchmark. The project economics for the application

\begin{tabular}{|c|c|c|c|c|c|c|c|c|}
\hline \multicolumn{9}{|c|}{ 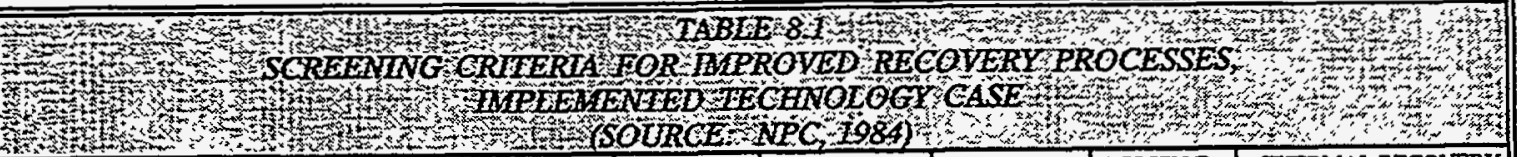 } \\
\hline SCREENING PARAMETERS & UNIIS & $\begin{array}{l}\text { PROFILE } \\
\text { MODIFI- } \\
\text { CATION }\end{array}$ & $\begin{array}{l}\text { POLYMER } \\
\text { FLOODNG }\end{array}$ & $\begin{array}{l}\text { SURFACTANT } \\
\text { FLOODING }\end{array}$ & $\begin{array}{l}\text { ALKALINE } \\
\text { FLOODING }\end{array}$ & $\begin{array}{l}\text { MISCIBLE } \\
\text { FLOODING } \\
\text { (CARBON } \\
\text { DIOXIDE) }\end{array}$ & STEAM C & $\begin{array}{l}\text { N SITU } \\
\text { MBUSTION }\end{array}$ \\
\hline OIL GRAVTY & ${ }^{\circ} \mathrm{API}$ & - & - & $=$ & $<30$ & $\geq 25$ & 10 to 34 & 10 to 35 \\
\hline IN SIIU OII VISCOSITY $(\mu)$ & $\mathbf{c P}$ & $<100$ & $<100$ & $<40$ & $<90$ & - & $\leq 15,000$ & $\leq 5,000$ \\
\hline DEPTH (D) & Feet & - & - & - & - & - & $\leq 3,000$ & $\leq 11,500$ \\
\hline PAY ZONE THICKNESS (H) & Feet & - & - & - & $=$ & $=$ & $\geq 20$ & $\geq 20$ \\
\hline RESERVOIR TEMPERATURE $\left(T_{R}\right)$ & ${ }^{\circ} \mathrm{F}$ & $<180$ & $<200$ & $<200$ & $<200$ & - & - & - \\
\hline POROSITY (ळ) & Fraction & $\overline{-}$ & - & - & - & - & $\geq 0.20^{(2)}$ & $20.20^{(2)}$ \\
\hline PERMEABIITY, AVERAGE $(k)$ & $\mathrm{mD}$ & $>20$ & $>20$ & $>40$ & $\mathbf{2 0}$ & - & 250 & 35 \\
\hline TRANSMISSIBI $\Pi T Y(\mathrm{kh} / \mu)$ & $\mathrm{mD} / \mathrm{A}-\mathrm{cP}$ & - & $=$ & - & - & - & $\geq 5$ & 25 \\
\hline RESERVOIR PRESSURE $\left(\mathrm{P}_{\mathrm{R}}\right)$ & psi & - & - & - & - & $\geq \mathrm{MMP}^{(1)}$ & $\leq 1,500$ & $\leq 2,000$ \\
\hline $\begin{array}{l}\text { MINMUM OIL CONTENT AT START } \\
\text { OF PROCESS }\left(S_{0} \times,\right)\end{array}$ & Frection & - & - & - & $=$ & - & $\geq 0.10$ & $\geq 0.08$ \\
\hline $\begin{array}{l}\text { SALINITY OF FORMATION } \\
\text { BRINE (IDS) }\end{array}$ & ppm & $\begin{array}{c}<100,00 \\
0\end{array}$ & $<100,000$ & $<100,000$ & $<100,000$ & - & - & - \\
\hline ROCK TYPE & - & & $\begin{array}{c}\text { Sandstone } \\
\text { or } \\
\text { Carbonate }\end{array}$ & Sardstone & Sandstone & $\begin{array}{c}\text { Sandstone } \\
\text { or } \\
\text { Carbonate }\end{array}$ & $\begin{array}{c}\text { Sandstone } \\
\text { or } \\
\text { Carbonate }\end{array}$ & $\begin{array}{c}\text { Sandstone } \\
\text { or } \\
\text { Carbonate }\end{array}$ \\
\hline
\end{tabular}

(1) MMP denotes minimum miscibility pressure, which depends on temperature and cride oil composition.

(2) Ignored if oil saturation $\left(S_{0}\right)$ x porosity $(\emptyset)$ criteria are satisfied. 


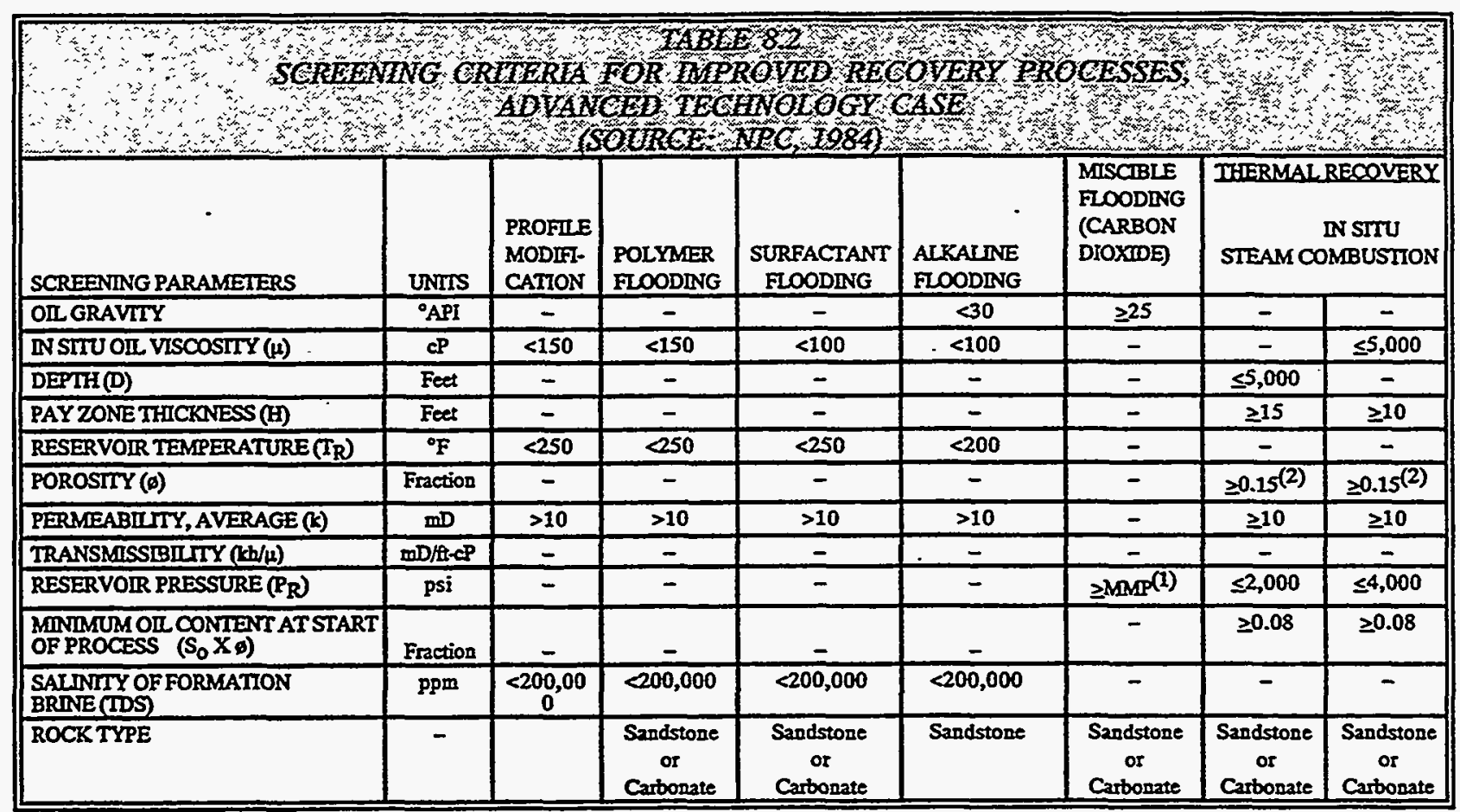

(1) MMP denotes minimum miscibility pressure, which depends on temperature and crude oil composition.

(2) Ignored if oil saturation $\left(S_{0}\right) \times$ porosity $(\phi)$ criteria are satisfied.

of the viable recovery processes in each reservoir are compared at each oil price and the optimum process is selected based on oil recovery volumes and projected rates of return. The recovery processes are considered to be viable in TORIS if the project rate of return exceeds defined minimum hurdle rates. Because the goal of the DOE R\&D effort is to maximize the recovery of the remaining oil resource, TORIS is set up to select the viable process which recovers the most oil from each reservoir, rather than to select the process with the best economics. The maximum oil recovery potential for a group of reservoirs can then be defined for both the implemented and advanced technology cases.

\subsection{Improved Recovery Potential for Class 4}

The recovery potential for the Class 4 TORIS reservoirs was evaluated for the implemented and advanced technology cases described above at oil prices of $\$ 12, \$ 20$, and $\$ 30$ per barrel. The total recovery potential for Class 4 ranges between 1.0 and 4.3 billion barrels depending on the prevailing oil price and the level of technology advancement, as summarized in Table 8.3. For the implemented technology case, which is essentially the future application of existing recovery technologies, the recovery potential ranges from 1.0 billion barrels at $\$ 12 /$ barrel to 1.8 billion barrels at $\$ 30$ / barrel. The majority of this potential is attributable to the expanded application of advanced secondary recovery processes. If reasonable technological advancements can be achieved, the recovery potential increases significantly for Class 4, ranging from 1.7 to 4.3 billion barrels at oil prices of $\$ 12$ to $\$ 30 /$ barrel, respectively. The majority of the advanced technology case potential is attributable to the application of ASR technologies in the $\$ 12$ and $\$ 20 /$ barrel cases, but EOR technologies have the greater impact in the $\$ 30 /$ barrel case. 


\begin{tabular}{|c|c|c|c|c|c|c|}
\hline \multirow[b]{4}{*}{$\begin{array}{l}\text { OII PRICE } \\
\text { (WTI) } \\
\text { (S/BBL) }\end{array}$} & 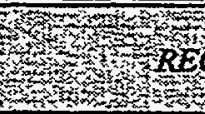 & OWERT & 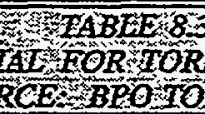 & 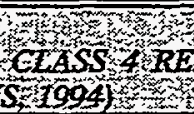 & 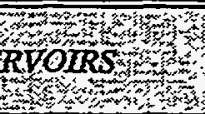 & 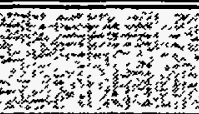 \\
\hline & \multicolumn{6}{|c|}{ RECOVERY POTENTLAL IN MIILUONS OF BARRELS } \\
\hline & \multicolumn{2}{|c|}{$\begin{array}{c}\text { ADVANCED } \\
\text { SECONDARY RECOVERY }\end{array}$} & \multicolumn{2}{|c|}{ ENHANCED OIL RECOVERY } & \multicolumn{2}{|c|}{ TOTAL POTENTIAL } \\
\hline & $\begin{array}{l}\text { DMPLEMENTED } \\
\text { TECHNOLOGY }\end{array}$ & $\begin{array}{l}\text { ADVANCED } \\
\text { IECHNOLOGY }\end{array}$ & $\begin{array}{l}\text { IMPLEMENTED } \\
\text { TECHNOLOGY }\end{array}$ & $\begin{array}{l}\text { ADVANCED } \\
\text { TECHNOLOGY }\end{array}$ & $\begin{array}{l}\text { IMPLEMENTED } \\
\text { TECHNOLOGY }\end{array}$ & $\begin{array}{l}\text { ADVANCED } \\
\text { TECHNOLOGY }\end{array}$ \\
\hline 12 & 995 & 1,641 & 10 & 88 & 1,005 & 1,729 \\
\hline 20 & 1,150 & 1,784 & 372 & 1,245 & 1,522 & 3,029 \\
\hline 30 & 1,193 & 1,974 & 646 & 2,354 & 1,839 & 4,328 \\
\hline
\end{tabular}

The advanced secondary recovery potential for Class 4 increases from 1.0 billion barrels at $\$ 12 /$ barrel to 1.2 billion barrels at $\$ 30 /$ barrel for the implemented technology case, while the recovery potential for the advanced technology case increases from 1.6 to 2.0 billion barrels at $\$ 12 /$ barrel and \$30/barrel, respectively (Figure 8.1). Most of this ASR potential is attributable to infill drilling alone and in combination with polymer flooding and profile modification. ASR recovery potentials by process for the various cases considered are summarized in Table 8.4.

The enhanced oil recovery potential for Class 4 increases from 10 million barrels at $\$ 12 /$ barrel to 646 million barrels at $\$ 30 /$ barrel for the implemented technology case, while the recovery potential for the advanced technology case increases from 88 million barrels to nearly 2.4 billion barrels at $\$ 12 /$ barrel and $\$ 30 /$ barrel, respectively (Figure 8.2). Most of the EOR potential in the implemented technology case results from the expansion of ongoing steamfloods, with some additional potential for $\mathrm{CO}_{2}$ and surfactant flooding at the higher oil prices. In the advanced technology case, most of the EOR potential results from the application of chemical flooding processes, with some contribution from in situ combustion, $\mathrm{CO}_{2}$ flooding, and new steamflood projects at higher prices. EOR recovery potentials by process for the various cases considered are summarized in Table 8.5.

Examination of the data shown in Tables 8.4 and 8.5 reveals that the recovery potential for the individual processes does not necessarily increase as the oil price increases. This phenomena is a result of the TORIS selection methodology described in Section 8.1. At each oil price, TORIS selects the recovery process for each reservoir in order to maximize oil recovery. So for any given reservoir, the selected recovery process may be different at one oil price than at another. For example, infill drilling may be the selected process in a given reservoir at $\$ 12$ or $\$ 20 / \mathrm{barrel}$, but at $\$ 30 /$ barrel, one of the other ASR or EOR processes may recover more oil economically than infill drilling. The end result is that the overall recovery potential for the Class 4 reservoirs does increase as the oil price increases, and oil recovery is maximized.

\subsection{Abandonment Risk of the Class 4 Resource}

A significant portion of the Class 4 resource is at risk of abandonment by the year 2000 , meaning that many of the reservoirs that have potential for future application of improved recovery technologies could be abandoned prior to the initiation of these projects. For the implemented technology case considered in this analysis, nearly 740 million barrels of the 1 billion barrel recovery potential at $\$ 12 /$ barrel is at risk of abandonment by the year 2000 . At $\$ 30 /$ barrel, 1.2 billion 


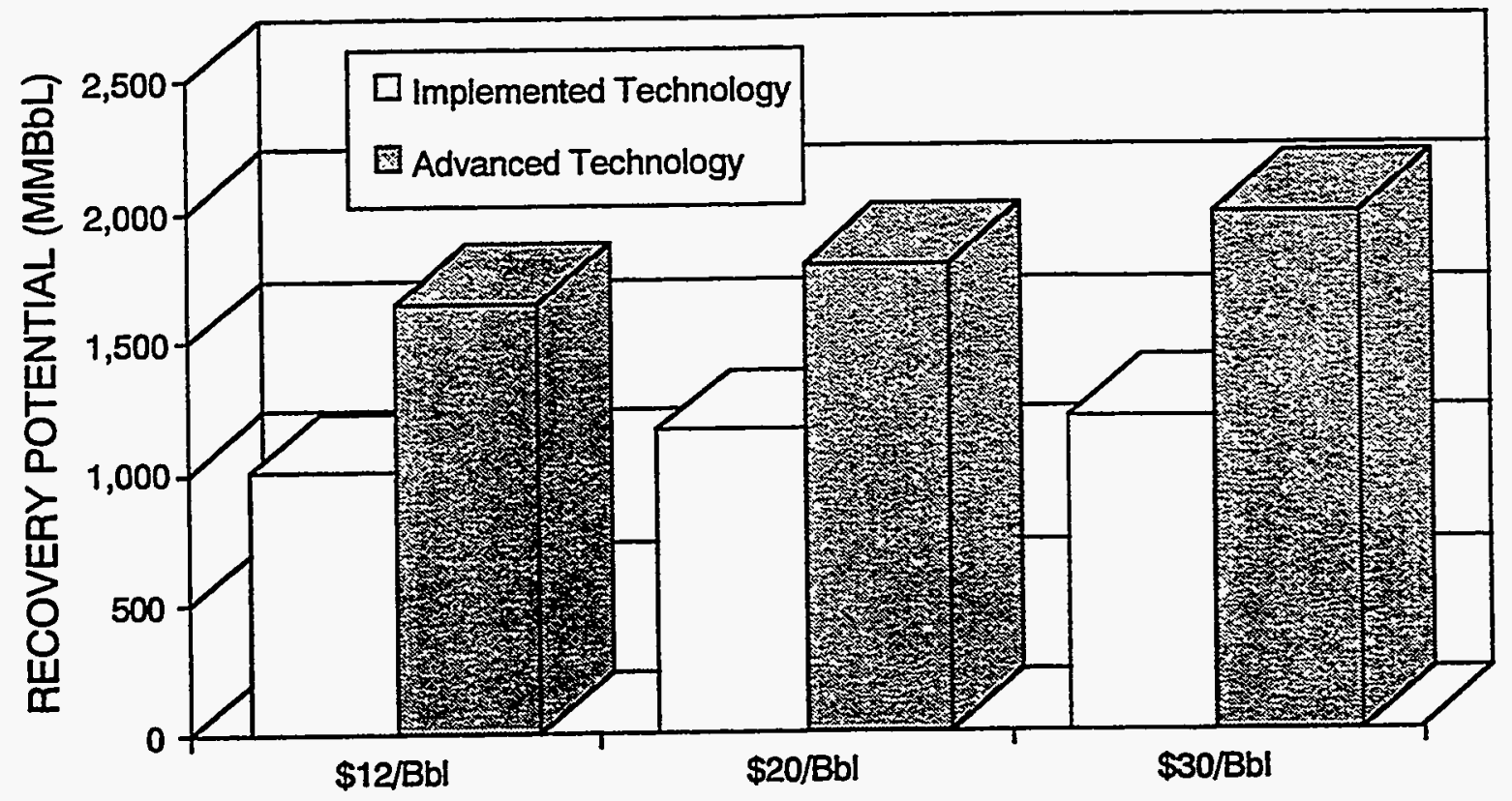

Figure 8.1 Advanced Secondary Recovery Potential for Class 4 Res-
ervoirs (Source: BPO TORIS, 1994)

\begin{tabular}{|c|c|c|c|c|c|c|}
\hline \multicolumn{7}{|c|}{ 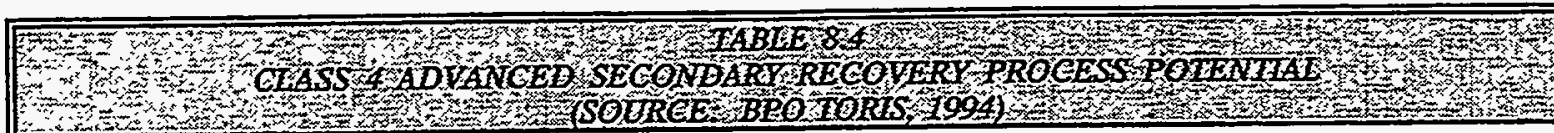 } \\
\hline \multirow[b]{3}{*}{ RECOVERY PROCESS } & \multicolumn{6}{|c|}{ RECOVERY POTENTIAL IN MIILIONS OF BARRELS } \\
\hline & \multicolumn{3}{|c|}{ IMPLEMENTED TECHNOLOGY } & \multicolumn{3}{|c|}{ ADVANCED TECHNOLOGY } \\
\hline & $\$ 12 / B B L$ & $\$ 20 / B B L$ & $\$ 30 / \mathrm{BBL}$ & $\$ 12 / B B L$ & $\$ 20 / B B L$ & $\$ 30 / B B L$ \\
\hline INFIL DRILING & 214 & 283 & 289 & 127 & 120 & 164 \\
\hline POLYMER FLOODING & 35 & 50 & 53 & 58 & 49 & 50 \\
\hline PROFILE MODIFICATION & 66 & 60 & 58 & 86 & 80 & 75 \\
\hline INFLL_POLYMER & 370 & 364 & 384 & 558 & 596 & 655 \\
\hline $\begin{array}{l}\text { INFLL/PROFILE } \\
\end{array}$ & 310 & 393 & 409 & 812 & 939 & 1,030 \\
\hline & 995 & 1,150 & 1,193 & 1,641 & 1,784 & 1,974 \\
\hline
\end{tabular}




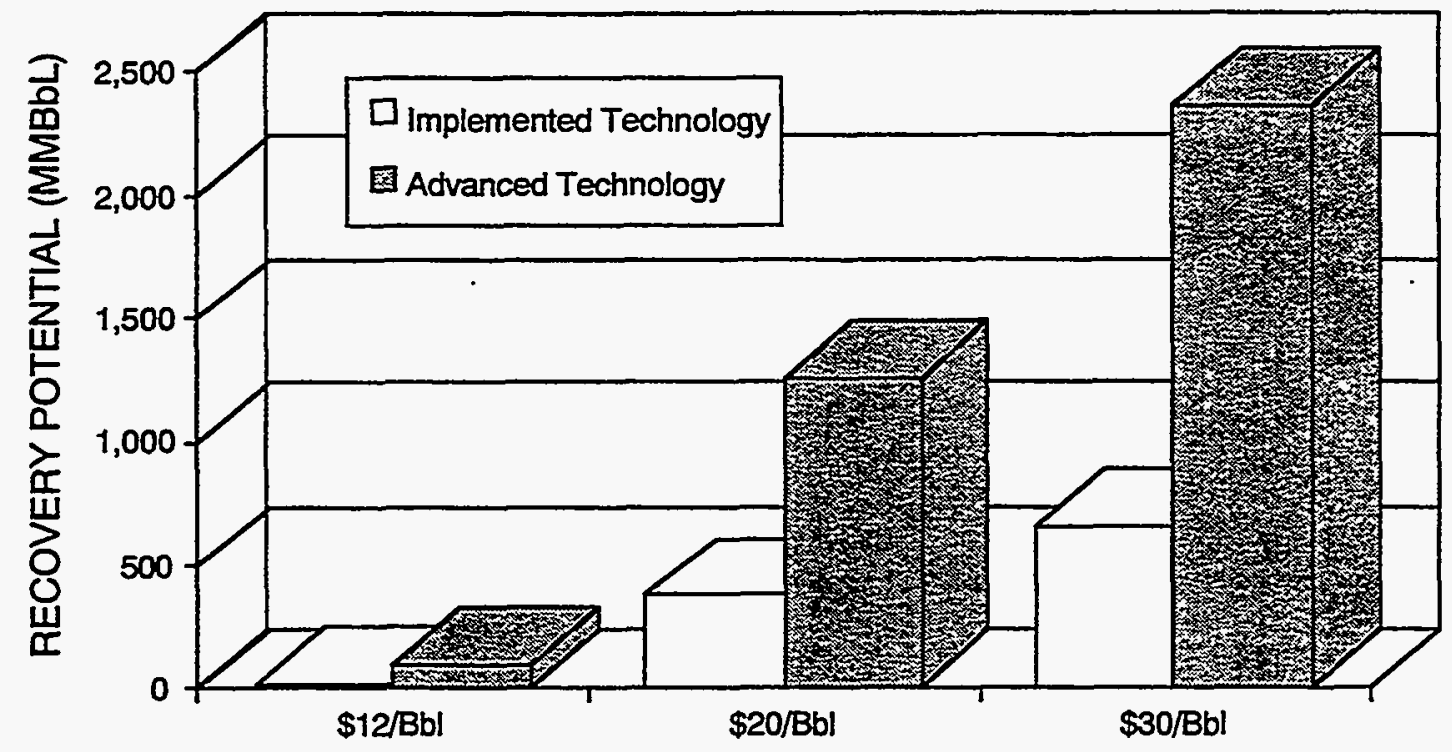

Figure 8.2 Enhanced Oil Recovery Potential for Class 4 Reservoirs (Source: BPO TORIS, 1994)

\begin{tabular}{|c|c|c|c|c|c|c|}
\hline \multicolumn{7}{|c|}{ 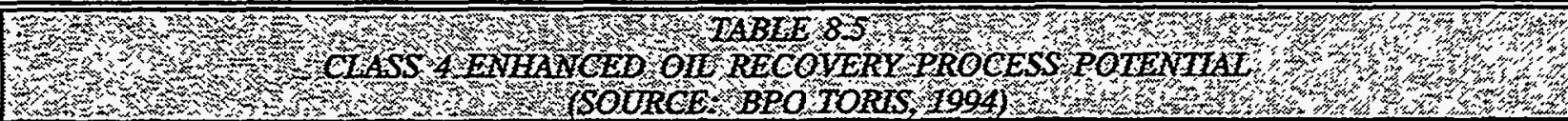 } \\
\hline \multirow[b]{3}{*}{ RECOVERY PROCESS } & \multicolumn{6}{|c|}{ RECOVERY POTENTIAL IN MILLIONS OF BARRELS } \\
\hline & \multicolumn{3}{|c|}{ IMPLEMENTED TEĆHNOLOGY } & \multicolumn{3}{|c|}{ ADVANCED TECHNOLOGY } \\
\hline & $\$ 12 / \mathrm{BBL}$ & $\$ 20 / \mathrm{BBL}$ & $\$ 30 / \mathrm{BBL}$ & $\$ 12 / \mathrm{BBL}$ & $\$ 20 / \mathrm{BBL}$ & $\$ 30 / B B L$ \\
\hline $\mathrm{CO}_{2}$ MISCIBLE & 0 & 101 & 170 & 0 & 74 & 142 \\
\hline ALKALINE & 0 & 0 & 0 & 66 & 307 & 117 \\
\hline SURFACTANT & 0 & 8 & 117 & 9 & 755 & 1,548 \\
\hline NEW STEAM & 9 & 18 & 46 & 13 & 23 & 197 \\
\hline $\begin{array}{l}\text { EXPANSION OF ONGOING } \\
\text { STEAMFLOODS }\end{array}$ & $\overline{0}$ & 241 & 285 & 0 & 0 & 0 \\
\hline IN SITU COMBUSTION & 0 & 4 & 28 & 0 & 86 & 350 \\
\hline TOTAL & 10 & 371 & 646 & 88 & 1,245 & 2,354 \\
\hline
\end{tabular}

barrels of the potential 1.8 billion barrels could be abandoned by the year 2000 (Figure 8.3 ). For the advanced technology case, 1.4 billion barrels of the 1.7 billion barrel recovery potential at $\$ 12 /$ barrel could be abandoned by the year 2000, while 2.3 billion barrels of the 4.3 billion barrel potential at $\$ 30 /$ barrel is at risk of abandonment (Figure 8.4 ). Only a minor portion of both the implemented and advanced recovery potential is at risk of abandonment after the year 2000 . The magnitude of the Class 4 recovery potential which is at risk of abandonment in the next six years illustrates the urgent need for the development and demonstration of cost-effective recovery technologies. 


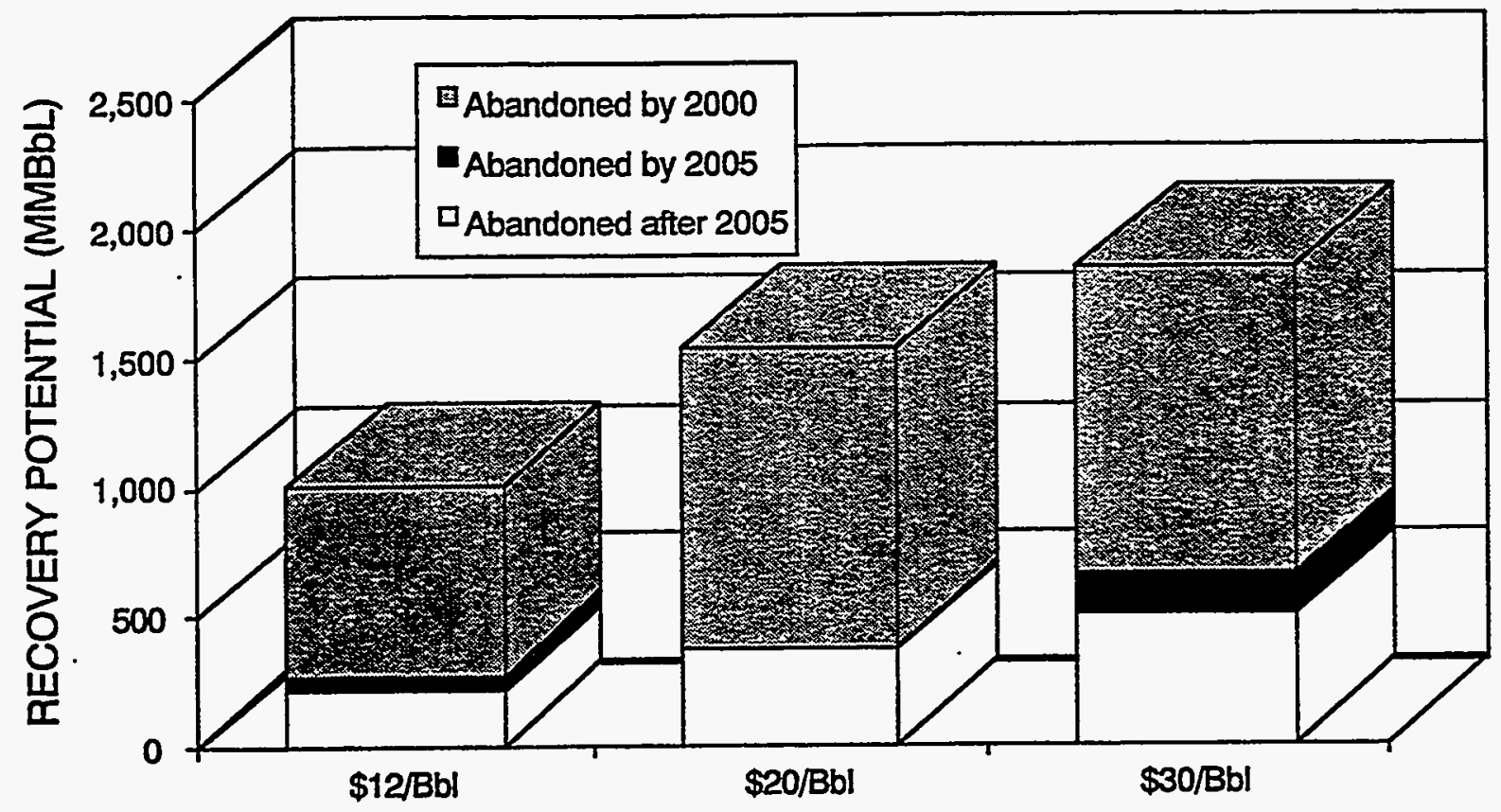

Figure 8.3 Total Potential at Risk of Abandonment, Implemented Technology (Source: BPO TORIS, 1994)

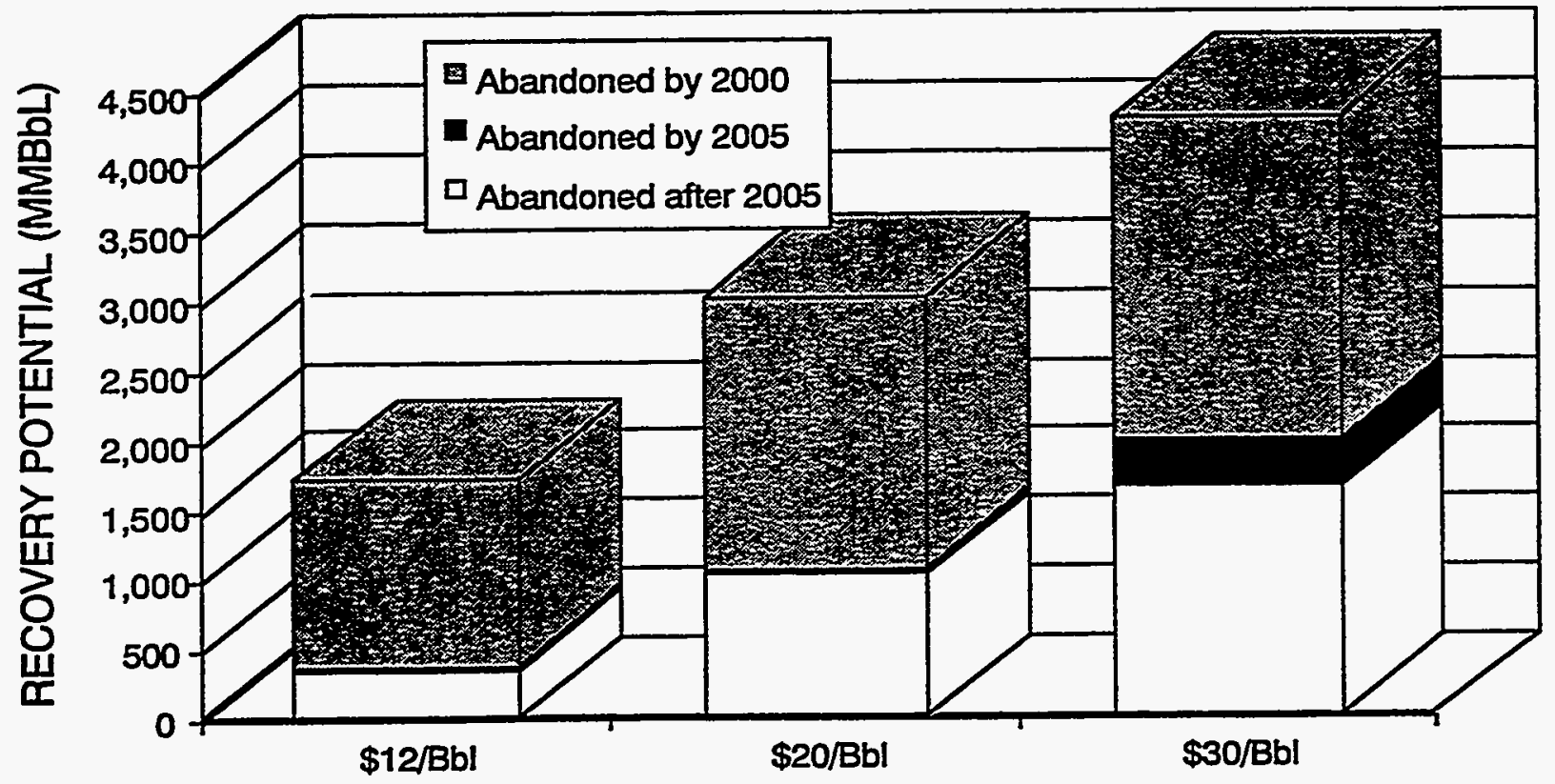

Figure 8.4 Total Potential at Risk of Ȧbandonment, Advanced Technology (Source: BPO TORIS, 1994) 


\subsection{Discussion of Recovery Potential for Class 4 by Region}

Most of the improved oil recovery potential for Class 4 results from the future application of recovery technologies in Texas, Oklahoma, California, and the Rocky Mountains. The recovery potentials for these regions at various oil prices are summarized for the implemented technology case in Table 8.6, and for the advanced technology case, in Table 8.7.

The improved recovery potential for the Class 4 reservoirs in Texas ranges from 358 million barrels at $\$ 12 /$ barrel to 659 million barrels at $\$ 30 /$ barrel for the implemented technology case, while in the advanced technology case the recovery potential ranges from 614 million barrels at $\$ 12 /$ barrel to 1.6 billion barrels at $\$ 30 /$ barrel. In the implemented technology case, most of the recovery potential is realized through the application of infill drilling in combination with polymer applications. At \$30/barrel, over one-third of the implemented technology case recovery potential is realized from the application of chemical and $\mathrm{CO}_{2}$ flooding processes. In the advanced technology case, most of the Texas improved recovery potential at the higher oil prices results from the application of the EOR processes, primarily chemical flooding (alkaline and surfactant), in situ combustion, and $\mathrm{CO}_{2}$ flooding processes. The ASR processes contribute between 538 and 620 million barrels of the advanced recovery technology case potential, depending upon oil price.

\begin{tabular}{|c|c|c|c|c|c|c|c|c|c|}
\hline \multicolumn{10}{|c|}{ 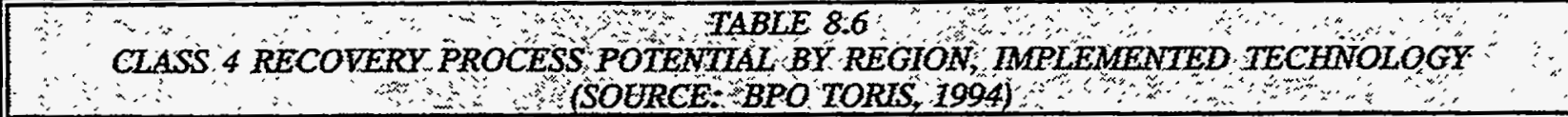 } \\
\hline \multirow[b]{3}{*}{ REGION } & \multicolumn{9}{|c|}{ RECOVERY POTENTLAL IN MILLIONS OF BARREIS } \\
\hline & \multicolumn{3}{|c|}{$\begin{array}{c}\text { ADVANCED SECONDARY } \\
\text { RECOVERY }\end{array}$} & \multicolumn{3}{|c|}{ ENHANCED OIL RECOVERY } & \multicolumn{3}{|c|}{$\begin{array}{c}\text { TOTAL RECOVERY } \\
\text { POTENTIAI }\end{array}$} \\
\hline & $\$ 12 / \mathrm{BB} 1$ & $\$ 20 / \mathrm{BBL}$ & S30/BBL & $\$ 12 / \mathrm{BBL}$ & $\$ 20 / \mathrm{BBL}$ & \$30/BBL & $\$ 12 / B B L$ & $\$ 20 / B B L$ & $\$ 30 / \mathrm{BBL}$ \\
\hline TEXAS & 358 & 403 & 429 & 0 & 81 & 230 & 358 & 484 & 659 \\
\hline OKLAHOMA & 280 & 318 & 322 & 0 & 0 & 14 & 280 & 318 & 336 \\
\hline CALIFORNLA & 112 & 119 & 119 & 10 & 264 & 342 & 122 & 382 & 461 \\
\hline ROCKY MOUNTALN & 208 & 249 & 257 & 0 & 27 & 60 & 208 & 277 & 317 \\
\hline OTHER & 37 & 61 & 66 & 0 & 0 & 0 & 37 & 61 & 66 \\
\hline TOTAL & 995 & 1,150 & 1,193 & 10 & 372 & 646 & 1,005 & 1,522 & 1,839 \\
\hline
\end{tabular}

\begin{tabular}{|c|c|c|c|c|c|c|c|c|c|}
\hline \multirow[b]{3}{*}{ REGION } & \multicolumn{9}{|c|}{ RECOVERY POTENTIAI IN MILUIONS OF BARRELS } \\
\hline & \multicolumn{3}{|c|}{$\begin{array}{l}\text { ADVANCED SECONDARY } \\
\text { RECOVERY } \\
\end{array}$} & \multicolumn{3}{|c|}{ ENHANCED OL RECOVERY } & \multicolumn{3}{|c|}{$\begin{array}{c}\text { TOTAL RECOVERY } \\
\text { POTENTLAL }\end{array}$} \\
\hline & S12/BBI & \$2O/BBL & $\$ 30 / \mathrm{BBL}$ & \$12/BBL & $\$ 20 / B B L$ & \$30/BBL & \$12/BBL & \$20/BBL & S30/BBL \\
\hline TEXAS & 538 & 588 & 620 & 76 & 756 & 993 & 614 & 1,344 & 1,613 \\
\hline OKIAHOMA & 492 & 518 & 588 & 0 & 342 & 802 & 492 & 860 & 1,390 \\
\hline CAIIFORNIA & 111 & 114 & 139 & 12 & 65 & 397 & 123 & 178 & 536 \\
\hline ROCKY MOUNTAIN & 447 & 492 & 549 & 0 & 74 & 129 & 447 & 566 & 678 \\
\hline OTHER & 53 & 72 & 78 & 0 & 8 & 33 & 53 & 81 & 111 \\
\hline TOTAI & 1,641 & 1,784 & 1,974 & 88 & 1,245 & 2,354 & 1,729 & 3,029 & 4,328 \\
\hline
\end{tabular}


The improved oil recovery potential for Oklahoma in both the implemented and advanced technology cases is dominated by the ASR technologies at $\$ 12 /$ barrel and $\$ 20 / \mathrm{barrel}$, but at $\$ 30 / \mathrm{barrel}$ in the advanced technology case, the application of EOR technologies results in over 800 million barrels of the total 1.4 billion barrel potential. For the implemented technology case, the future recovery potential for Oklahoma ranges from 280 to 336 million barrels, depending upon oil price. Virtually all of this potential results from infill drilling, with additional potential from polymer flooding and infill drilling in combination with polymer applications. These ASR processes also contribute between 492 and 588 million barrels of the advanced technology case potential at $\$ 12$ and $\$ 30 / b a r r e l$, respectively. In the advanced technology case, the future application of chemical flooding EOR processes results in recovery potential of 342 million barrels at $\$ 20 /$ barrel and 802 million barrels at \$30/barrel.

The improved recovery potential for California ranges from 122 million barrels at $\$ 12 /$ barrel to 461 million barrels at $\$ 30 / \mathrm{barrel}$ in the implemented technology case and from 123 million barrels at $\$ 12 /$ barrel to 536 million barrels at $\$ 30 /$ barrel in the advanced technology case. Most of this potential results from the expanded application of thermal processes in the Class 4 reservoirs. Additional potential is also realized from infill drilling and profile modification.

The improved recovery potential in the Rocky Mountain Class 4 reservoirs primarily results from the application of advanced secondary recovery processes. In the implemented technology case, the total recovery potential ranges from 208 to 317 million barrels at $\$ 12$ and $\$ 30 /$ barrel, respectively. This potential results almost exclusively from infill drilling in combination with polymer flooding and profile modification. This potential increases in the advanced technology case to 447 million barrels at $\$ 12 /$ barrel and 678 million barrels at $\$ 30 /$ barrel. Minor potential is also realized in the advanced technology case for chemical flooding, polymer flooding, $\mathrm{CO}_{2}$ flooding, and profile modification processes.

\subsection{Reference}

National Petroleum Council, 1984, Enhanced Oil Recovery, Washington D.C. 


\section{CHAPTER 9 \\ ENVIRONMENTAL ISSUES RELATED \\ TO PRODUCTION OPERATIONS}

Environmental issues that face oil production operations targeted at Class 4 reservoirs are not different than activities targeted at other reservoir types. Rather, environmental issues are tied to the location of the project (i.e., relationship of the project with existing oil production activities, surface and groundwater, urban areas, sensitive areas such as wetlands, floodplains, tundra, and coastal areas, the presence of listed endangered species or habitats, and the presence of historical, archeological, or paleontological sites) and the activities that occur during the project (i.e., construction of surface facilities, such as pipelines, fences, roads, pads, and buildings and recovery processes that may use fresh water and produce waste water, air emissions, solid waste, or noise). Activities conducted as part of DOE's program of field demonstrations in high-priority reservoir classes must have and comply with the usual and appropriate federal, state, and local environmental permits required of all similar oil production operations.

Production operations targeting Class 4 reservoirs do not entail any special environmental issues; factors that determine the nature and magnitude of potential environment impacts are siteand project-specific, such as:

- Environmental setting of the project including factors such as surface water, groundwater, land use, historic sites, wetlands, endangered species, socio-economic factors, etc.;

- Recovery operations involving facilities construction, water discharge, air emissions, waste generation, etc.; and

- Local, state, and federal regulatory requirements.

A complete discussion of environmental issues related to production operations would be too lengthy for this report and would be made obsolete by new legislation or regulations. Information can be obtained from a variety of sources including local, state, and federal government agencies, industry associations, libraries, historical societies, and consultants. A report is available from DOE that summarizes environmental regulatory requirements of the various states and provides points of contact for additional guidance (Madden et al., 1991). An organization that can provide considerable information is the Interstate Oil and Gas Compact Commission (IOGCC) in Oklahoma City, OK.

\subsection{National Environmental Policy Act}

Compliance with NEPA is a specific requirement of conducting work with the federal government. Basically, NEPA requires that potential environmental impacts and mitigating factors be considered in planning any federal action, i.e., before making a decision to expend federal funds, environmental consequences of the proposed action and alternative actions must be considered.

Making a sound decision requires adequate information about environmental conditions that might be impacted by the proposed activity. The types and possible sources of information that are useful in assessing environmental impacts are presented in Table 9.1. Since collecting all pertinent 


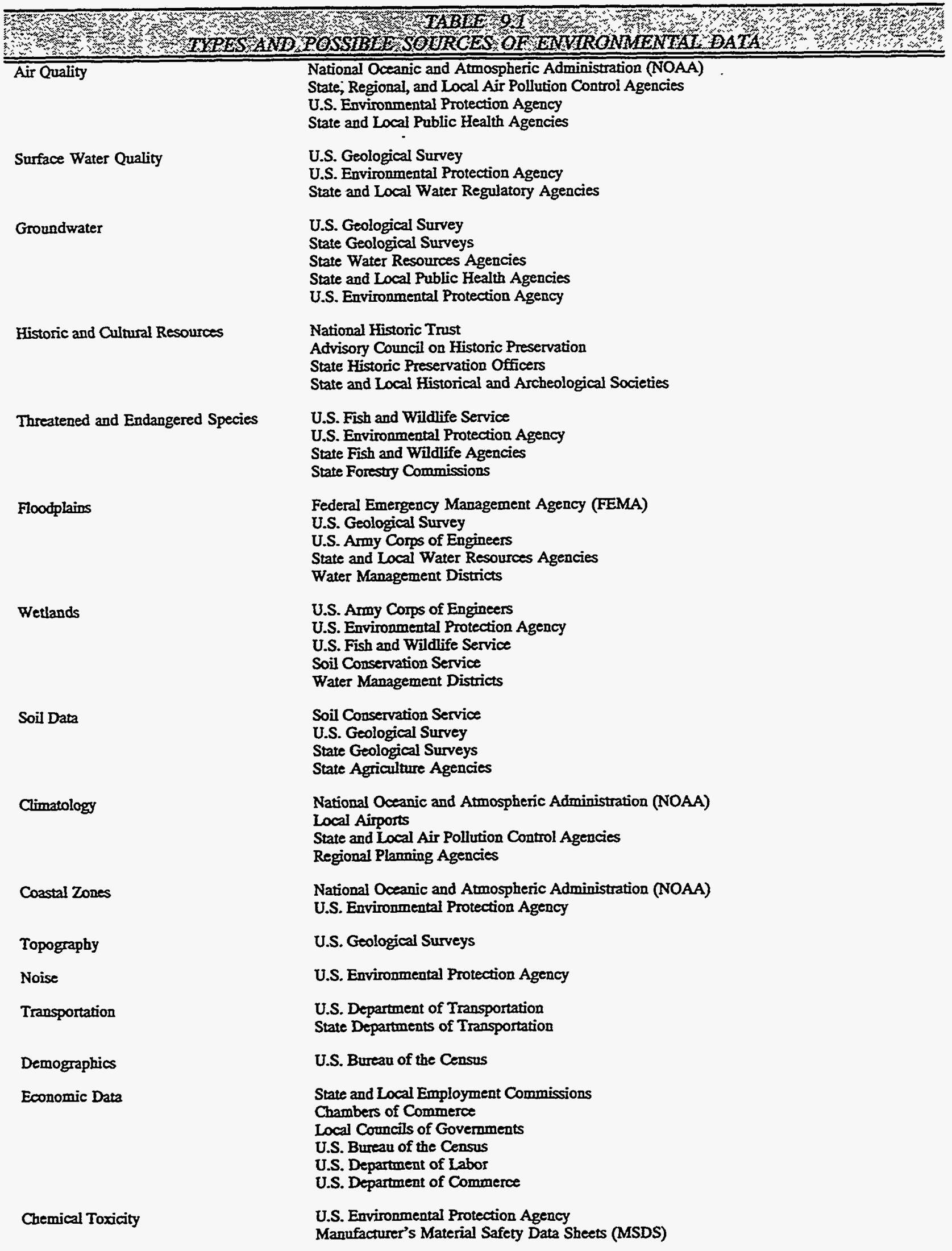


data can be time consuming, only those organizations selected to participate in demonstration projects will be required to collect complete information. Activities that will be part of a project are also considered for NEPA assessment. Pertinent factors include the following:

- Will new wells be drilled and, if so, will they be infill wells?

- Is the project site in an area in which oil production activities have occurred previously?

- Will surface construction, such as roads, buildings, pads, pipelines, be required?

- Will water discharges or air emissions occur? and

- Will hazardous waste be generated?

In the event that the proposed project likely will have an adverse environmental impact, measures proposed to mitigate the impact are an important part of the NEPA decision process. Examples of environmental concerns related to specific recovery processes are presented in Table 9.2.

In case the nature and magnitude of the potential environmental impacts are uncertain, NEPA requires that an Environmental Assessment (EA) be performed. The two possible outcomes of an EA are: (1) a determination that significant impacts may result from the action, in which case an Environmental Impact Statement (EIS) must be prepared; or (2) a determination that significant impacts are unlikely to occur in which case a Finding of No Significant Impact (FONSI) will be

\begin{tabular}{|c|c|c|c|c|}
\hline Issue & Steam Injection & In Situ Combustion & Chemical Flooding & $\mathrm{CO}_{2}$ Injection \\
\hline Air & $\begin{array}{l}\mathrm{SO}_{2} \mathrm{NO}_{\infty} \text { and } \mathrm{PM}_{10} \\
\text { emissions from steam } \\
\text { generators } \\
\text { Wellhead emissions of } \\
\mathrm{HC}\end{array}$ & $\begin{array}{l}\mathrm{HC} \text { and } \mathrm{CO} \text { emissions } \\
\text { from wells } \\
\mathrm{SO}_{2}, \mathrm{NO}_{x} \text { and } \mathrm{TSP} \\
\text { emissions from air } \\
\text { compressors }\end{array}$ & $\begin{array}{l}\text { Fugitive emissions } \\
\text { from on-site } \\
\text { manufacture of } \\
\text { chemicals }\end{array}$ & $\begin{array}{l}\text { Leaks of } \mathrm{CO}_{2} \text { in } \\
\text { process use or transport } \\
\mathrm{H}_{2} \mathrm{~S} \text { emissions from } \\
\text { wells }\end{array}$ \\
\hline Water Use & $\begin{array}{l}\text { Sigmificant water } \\
\text { demand }\end{array}$ & $\begin{array}{l}\text { Moderate water demand } \\
\text { in wet combustion } \\
\text { processes }\end{array}$ & $\begin{array}{l}\text { Significant water } \\
\text { demand }\end{array}$ & $\begin{array}{l}\text { Significant water } \\
\text { demand }\end{array}$ \\
\hline $\begin{array}{l}\text { Water } \\
\text { Effluent }\end{array}$ & $\begin{array}{l}\text { Disposal of produced } \\
\text { water }\end{array}$ & $\begin{array}{l}\text { Dispasal of produced } \\
\text { unater }\end{array}$ & $\begin{array}{l}\text { Aquifer contamination } \\
\text { from injected chemicals }\end{array}$ & $\begin{array}{l}\text { Disposal of produced } \\
\text { water }\end{array}$ \\
\hline & & $\begin{array}{l}\text { Aquifer contamination } \\
\text { from low } \mathrm{pH} \text { water } \\
\text { with trace metals } \\
\text { resulting from } \\
\text { corrosion of well } \\
\text { casings }\end{array}$ & $\begin{array}{l}\text { Disposal of produced } \\
\text { water } \\
\text { Spills or leaks of } \\
\text { chemicals to surface } \\
\text { waters }\end{array}$ & $\begin{array}{l}\text { Aquifer contamination } \\
\text { from low } \mathrm{pH} \text { water and } \\
\text { comosion of well } \\
\text { casings }\end{array}$ \\
\hline Solid Waste & $\begin{array}{l}\text { Disposal of scrubber } \\
\text { shudges } \\
\text { Disposal of water } \\
\text { treatment wastes }\end{array}$ & $\begin{array}{l}\text { Disposal of wastes } \\
\text { from wellhead gas } \\
\text { cleaning } \\
\text { Disposal of water } \\
\text { treatment wastes }\end{array}$ & $\begin{array}{l}\text { Disposal of wastes } \\
\text { from on-site chemical } \\
\text { mamufacture } \\
\text { Disposal of water } \\
\text { treatment wastes }\end{array}$ & $\begin{array}{l}\text { Disposal of water } \\
\text { treatment wastes }\end{array}$ \\
\hline
\end{tabular}

Key: Italicized entries are of major enviroumental concern; $\mathrm{SO}_{2}=$ sulfur dioxide, $\mathrm{NO}_{\mathrm{z}}=$ nitrogen oxides, $\mathrm{PM}_{10}=$ particulate matter $\leq 10 \mu$ in diameter, $\mathrm{HC}=$ hydrocarbons, $\mathrm{CO}=$ carbon monoxide, $\mathrm{TSP}=$ total suspended particulates, $\mathrm{CO}_{2}=$ carbon dioxide, $\mathrm{H}_{2} \mathrm{~S}=$ hydrogen sulfide 
prepared and an EIS will not be required. If a specific proposed action is similar to actions for which EAs have always resulted in FONSIs, then it is possible that the proposed action can be declared Categorically Excluded (CX) from further NEPA assessment, i.e., neither an EA nor an EIS will be required.

\subsection{Other Federal Regulations}

In addition to consideration of environmental factors in the planning process, the conduct of all demonstration projects must comply with applicable federal, state, and local regulations and be permitted by the appropriate agencies. As stated before, a complete summary here of all applicable regulations is not possible. A relatively complete summary of applicable regulations and agency points of contact can be found in the Environmental Regulations Handbook for Enhanced Oil Recovery (Madden et al., 1991). The American Petroleum Institute (API) has published guidelines for the management of solid waste in exploration and production operations (API, 1989).

Principal federal regulations that will be applicable to most oil production operations include, but are not limited to, the following:

- Resource Conservation and Recovery Act (RCRA) - The goals of RCRA are to protect human health and the environment, reduce or eliminate the generation of hazardous waste, and conserve energy and natural resources by regulating the management of active facilities (Oak Ridge National Laboratory, 1992a). Anyone who generates, transports, treats, stores, or disposes of hazardous waste must notify EPA of his or her activities and comply with RCRA. Drilling fluids, produced water and other wastes associated with exploration, development, or production of crude oil are exempt from regulation under RCRA (42 USC 6921 \$3001(b)(2)(A); also 40 CFR 261.4(b)(5); Arbuckle et al., 1991); however, they are regulated under regional or state solid waste disposal programs. States have jurisdiction to decide if wastes exempt from federal RCRA requirements are also exempt from state regulation as hazardous waste. Requirements vary from state to state.

- Safe Drinking Water Act (SDWA) - As it applies to oil and gas production operations, the SDWA is directed toward the prevention of contamination of underground sources of drinking water (USDW) by regulating underground injection and Underground Injection Control (UIC) programs (primarily 40 CFR 144, 145, 146, 147, and 148; Oak Ridge National Laboratory, 1992b). Wells related to oil and gas production that are used to inject fluids, either for improved recovery or fluid disposal, are called Class II injection wells. Regulations to implement the SDWA may not interfere with or impede the underground injection of brine or other fluids which are brought to the surface in connection with oil or natural gas production, or any underground injection for the secondary or tertiary recovery of oil or natural gas unless such requirements are essential to assure that underground sources of drinking water will not be endangered by such injection (42 USC 300h \$1421(b)(2)). Reporting, well construction, mechanical integrity testing, and area of review requirements vary from state to state. An organization that has considerable information regarding the requirements related to the SDWA is the Groundwater Protection Council (formerly the Underground Injection Practices Council) in Oklahoma City, OK. 
- Clean Water Act (CWA) - The objective of the CWA is to restore and maintain the chemical, physical, and biological integrity of the Nation's waters (Oak Ridge National Laboratory, 1993). Discharges from point sources into surface water are regulated and require permits under the National Pollution Discharge Elimination System (NPDES), $\$ 402$ of the act. Such discharges must meet certain quality and monitoring requirements that vary from state to state, and depend on the ambient quality and public use of the surface water. Specific implementing regulations that could be applicable to oil and gas production operations include those directed toward discharge of oil (40 CFR 110), oil pollution prevention related to non-transportation sources both on- and off-shore and the preparation of Spill Prevention Control and Countermeasures plans (40 CFR 112), designation of hazardous substances (40 CFR 125), water quality standards (40 CFR 131), guidelines establishing test procedures for the analysis of pollutants (40 CFR 136), and effluent guidelines and standards for various point source categories ( 40 CFR Subchapter $N$ ).

- Clean Air Act (CAA) - The CAA is directed toward the protection and enhancement of air quality. The CAA contains provisions for air pollution prevention and control, air quality and emission limitations, prevention of significant deterioration of air quality, requirements for non-attainment areas, emission standards for moving sources, acid deposition control, permits, and stratospheric ozone protection (Oak Ridge National Laboratory, 1991). Requirements vary from state to state and often vary between locations within a state.

- Endangered Species Act(ESA) and the related Fish and Wildlife Coordinating Act (FWCA)These acts are designed to protect plant and animal resources from adverse effects due to development projects. Both acts require consultation with wildlife authorities prior to committing resources to certain types of projects (Oak Ridge National Laboratory, 1989). An endangered species is one that is in danger of becoming extinct throughout all or a significant portion of its range. A threatened species is one that is likely to become endangered in the foreseeable future. The ESA makes it illegal to kill, collect, remove, harass, import, or export an endangered or threatened species without a permit from the Secretary of the Interior. The Act mandates coordination between the federal government and state and foreign governments. The purpose of the FWCA is to assure that fish and wildlife resources receive equal consideration with other values during the planning of development projects that affect water resources.

Other statutes that could affect oil production operations, but which will not be discussed here, include the Comprehensive Environmental Response, Compensation, and Liability Act (CERCLA); the Superfund Amendments and Reauthorization Act (SARA); the Oil Pollution Act; and the Toxic Substances Control Act (TSCA). To ensure that a specific oil production operation is conducted in compliance with all applicable environmental regulations, it is advisable that the operator contact the appropriate local, state, and federal regulatory agencies.

According to a study conducted by the American Petroleum Institute (Perkins, 1993), the petroleum industry spends more than $\$ 8$ billion per year on environmental quality protection. The study projects that new and potential environmental costs to the industry likely will range between $\$ 17$ billion and $\$ 25$ billion per year by the end of the 1990s. The abandonment of U.S. crude oil resources could be accelerated and the recovery potential decreased as a result of the cost of compliance with future regulatory requirements (ICF, 1990). One of the goals of the Domestic Natural 
Gas and Oil Initiative is to increase domestic natural gas and oil production and environmental protection by advancing and disseminating new exploration, production, and refining technologies (U.S. Department of Energy, 1993). Developing and utilizing recovery methods that are more cost effective and environmentally sound will help to mitigate the adverse impacts on production due to environmental regulations.

\subsection{References}

American Petroleum Institute, 1989, API Environmental guidance document-onshore solid waste management in exploration and production operations: American Petroleum Institute, Washington, D.C., Order No. 811-10850.

Arbuckle, J. Gordon et al., 1991, Environmental law handbook, 11th Edition, Government Institutes, Inc., Rockville, MD, 666 p.

Clean Air Act, 42 U.S.C. 7401 et seq.; Implementing regulations 40 CFR 50-52, 58, 60, 61, 124.

Clean Water Act, 33 U.S.C. 1251 et seq.; Implementing regulations 40 CFR 110, 112, 116, 117, $122,124,125,131,136,401,403,413,423,433,459$.

Endangered Species Act, 16 U.S.C. 1531 et seq.; Fish and Wildlife Coordinating Act, 16 U.S.C. 661 et seq.; Implementing regulations 50 CFR 17, 222, 225-227, 402, 424, 450, 451-453; ICF Resources, Inc. 1990, Potential cumulative impacts of environmental regulatory initiatives on U.S. crude oil exploration and production: Department of Energy Report DOE/FE/61679PH1.

ICF Resources Inc., 1990, Potential cumulative impacts of environmental regulatory initiatives on U.S. crude oil exploration and production: Department of Energy Report DOE/FE/61679P-H1.

Madden, M.P., R.P. Blachford, and R.B. Spears, 1991, Environmental regulations handbook for enhanced oil recovery: Department of Energy Report NIPER-546, $261 \mathrm{p}$.

National Environmental Policy Act, 42 U.S.C. 4321 et seq.; National Environmental Policy Act, Department of Energy implementing procedures and guidelines, 10 CFR 1021.

Oak Ridge National Laboratory, 1989, Environmental guidance program reference book - Endangered Species Act and the Fish and Wildlife Coordination Act, revision 5: Department of Energy Report ORNL/M-734.

Oak Ridge National Laboratory, 1991, Environmental guidance program reference book - Clean Air Act, revision 4: Department of Energy Report ORNL/M-1408.

Oak Ridge National Laboratory, 1992a, Environmental guidance program reference book - Resource Conservation and Recovery Act, revision 11: Department of Energy Report ORNL/M1897.

Oak Ridge National Laboratory, 1992b, Environmental guidance program reference book - Safe Drinking Water Act, revision 6: Department of Energy Report ORNL/M-1899. 
Oak Ridge National Laboratory, 1993, Environmental guidance program reference book - Clean Water Act, revision 6: Department of Energy Report ORNL/M-2263.

Perkins, Jody, 1993, Costs to the petroleum industry of major new and future Federal Government environmental requirements: American Petroleum Institute Discussion Paper \#070R.

Resource Conservation and Recovery Act, 42 U.S.C. 6901 et seq.; Implementing regulations 40 CFR 148, 260-281.

Safe Drinking Water Act, 42 U.S.C. 300 et seq.; Implementing regulations 40 CFR 124, 141-148.

U.S. Department of Energy, 1993, The domestic natural gas and oil initiative. 


\section{APPENDIXA \\ GLOSSARY OF GEOLOGICAL TERMS}

The purpose of this glossary of geological terms is not to reduce every geological term appearing in the text to laymen's language, but to provide sufficient background and explanation of key stratigraphic and sedimentological terms to allow the reader with a basic familiarity with natural processes to understand the origin and subsequent accumulation of strandplain/barrier island deposits. Most definitions found in this glossary have been taken or modified from the Glossary of Geology (Gary, M., R. McAfee, Jr., and C.L. Wolf, 1974, eds.: American Geological Institute, 857 p.). Many have been tailored to apply specifically to strandplain/barrier island deposits or simplified for a more general audience.

Aggrade, Aggradation - Building of a strandplain/barrier island complex in a vertical trend with time. In a hypothetical situation, where the rate of sediment influx exactly balances the rate of subsidence, the position of the coastline will remain fixed for long periods of time. The strandline will neither advance, nor retreat as the region subsides. In such cases, extremely thick sands will accumulate as the strandplain or barrier island deposit aggrades.

Arch - A relatively positive structural area. In the case of a subsiding region, an arch can also subside, but it will subside more slowly than the surrounding areas. In the case of the San Marcos Arch in Texas, the Arch was subsiding, along with the rest of the coast, but it was subsiding at a slower rate than the flanking embayments.

Aulacogen - A major fault-break in a continental plate where the Earth's crust has begun to separate. Such faulting is deep-seated, caused by movements in the mantle, and affects the entire crust at the site of the rift. Aulacogens typically fill with much greater sediment thicknesses than surrounding areas, and are often accompanied by volcanism and igneous activity. The East African Rift Valley System is an example of a developing aulacogen. The Southern Oklahoma Aulacogen failed to separate the crust completely.

Back-Barrier Sands - Sands deposited on the landward, lagoon side of a barrier island. These sands tend to have numerous layers of mud deposited in low-energy situations. These muds lithify into shaly streaks, which form low-permeability, unproductive zones in the sand. The thinnest shale streaks may be so thin that they are not recognized on electric logs, but they still can form permeability restrictions or barriers. These streaks can lower productivity and/or cause compartmentalization within the reservoirs.

Barrier Bar - (See barrier island)

Barrier Beach - (see offshore beach)

Barrier Core - The thickest, cleanest sediments in the center of a longshore bar or barrier island. The sediments deposited in a barrier core are constantly exposed to breaking waves. The wave energy washes out the fine-grained sediments, leaving behind a clean, sorted unit with the coarsest grain-size along a particular coast. Barrier core sands are generally massive, with little apparent bedding, and include beach and/or eolian dune facies. 
Barrier Island - Along, low, wave-built sandy (or coarser grained) island, parallel to the shore and exposed above high tide, commonly with dunes, vegetated zones, and swampy terrain. These islands shelter the coast and isolate shore waters in a lagoon between the shoreline and the island.

Barrier Peninsula - (see spit)

Barrier Spit - (see spit)

Barrier-Face Sand - (see fore-barrier sand)

Beach Plain - (see strandplain)

Beach Ridge - A low, essentially continuous mound of beach or beach-and-dune material heaped up by the action of waves and currents behind a beach beyond the limit of storm wave effects.

Also referred to as foreshore and backshore sands; well-sorted sands in massive beds or parallel (planar) beds with low-angle seaward dips; some small-scale cross stratification may occur near the lower contact with the distal bar facies; some shell and heavy mineral layers may be present.

This facies, along with the often overlying eolian facies, discussed below, constitutes the best reservoir rock associated with strandplain/barrier island systems.

Brackish - Referring to water with a salinity or salt content intermediate between fresh water and normal sea water.

Cape - An extensive rounded irregularity of land jutting out from the coast into a large body of water; a peninsula or a point.

Chronostratigraphy - The branch of stratigraphy that interprets geologic history by determining the age and time sequence of the earth's rock strata. Chronostratigraphy acknowledges and builds on the fact that the rock record contains significant gaps representing substantial and important periods of nondeposition and/or erosion.

Craton - A stable continental crust area. Over time, cratonic areas often undergo warping, and may be cut by faulting, but they have not been the site of major orogenies or mountain building.

Deep-Seated Faults - Faults that start at depth, often hundreds or thousands of feet below the surface. Deep-seated faults tend to be long-lived, remaining active over thousands of years. These faults may or may not reach the surface. Faults that do not reach the surface will generally cause surface and near-surface deposits to warp or bend over the projection of the fault.

Delta - Sedimentary deposit formed by sediment-laden moving water (e.g., current, river) when it loses speed upon entering a standing body of water (e.g., ocean, lake) and drops its sediment load.

Deltaic Deposit - Sediments deposited along a coast where a river is dumping large quantities of sediment into the coastal waters. Deltas generally build out into the water, except in situations where the coast is subsiding at a very rapid rate in excess of the rate of sediment supply by the river. 
Distal Bar - Also referred to as shoreface or fore-barrier sands; silt, sand and shale layers; sands may show some internal grading; common small-scale cross stratification; facies displays a general increase in grain size upward; may contain scattered shells.

This facies can be expected to have some reservoir quality sands, especially near its upper contact, but sands are generally thin and their lateral continuity may not be great

Dune - A low mound, ridge, bank or hill of loose, wind-blown granular material. These features form when sediments are exposed subaerially.

Ebb Tidal Currents - Tidal currents moving generally away from the shoreline as the tide falls or ebbs.

Ebb Tidal Delta - Asmall delta or deltaic-deposit formed at the seaward end of a tidal inlet as ebb tidal currents lose speed and drop their sediment load.

Embayment - An area of the coast that is subsiding at a relatively rapid rate. Rivers tend to flow to low-lying areas, so many embayments are also the site of major river deltas and thick sediment accumulations. Embayments may mark areas where the seashore moves inland from the general trend, but if sediment influx balances the increased rate of subsidence in an embayment, the coastline will follow the general trend without deviation.

Eolian - Also referred to as backshore and dune sands or barrier core sands (in part); clean wellsorted sands in massive beds or in large scale festoon cross-beds. This facies, along with the underlying beach ridge facies, constitutes the best reservoir rock associated with strandplain/barrier island systems.

Eustatic Sea Level Changes - Worldwide simultaneous sea level changes influenced only by changes in the total amount of water contained in the ocean basins or changes in their shape.

Facies - A sediment or rock type defined as having certain recognizable characteristics (e.g., having distinctive: color; mineralogic makeup; suite of sedimentary structures; faunal suite). Often facies are named genetically, i.e., based on their environments of origin.

Flood Tidal Currents - Tidal currents moving generally toward the shoreline as the tide rises or floods.

Flood Tidal Delta - A small delta or deltaic deposit formed at the landward or lagoonward end of a tidal inlet as flood tidal currents lose speed and drop their sediment load.

Fore Barrier Sands - Sands deposited on the deep-water side of a longshore bar, barrier island, or strandplain. Fore-barrier sediments are quite clean on the shoreface side of a deposit, but become dirtier with depth. Shallow-water fore-barrier sediments are deposited in the wave zone, and are washed clean of finer material. As the water deepens, however, waves have less effect, and fore-barrier deposits become dirtier.

Fore-Slope Sands - (see fore-barrier or shoreface sands)

Foreland - A prograded strip of low, flat land built by waves and currents at the base of a cliff.

Fluvial Deposits - Sediments deposited by a river system. Fluvial sediments occur inland from the coast. As river sediments reach the sea, they become deltaic sediments. 
Growth Faults - Normal faults that form contemporaneously with deposition due to sediment compaction and continue to move as deposition continues; sedimentary deposits associated with growth faults tend to display an aggradational architecture.

High-Energy Environment - Region of the coast with large amounts of wave action or strong water currents. Sediments in a high-energy environment are continuously worked and reworked by this moving water. Fine-grained sediments are constantly picked up, washed out and carried away to areas where the water is less active. The coarsest material remains behind in clean, well-sorted deposits, forming excellent reservoirs.

Incised Valley - A well-defined valley (from less than a mile to many tens of miles wide and from tens to many hundreds of feet in depth) that cuts sharply into sediments below an unconformity. They form in response to a relative fall in sea level, and fill with transgressive sediments as relative sea level rises.

Interdeltaic - Area of coastline between deltas. Usually little locally derived sediment reaches these regions. Sediments in interdeltaic areas are generally washed in from a relatively distant source by longshore currents.

Lagoon - The pool of quiet water trapped between an offshore barrier island and the mainland. Lagoonal environments include a wide variety of sediment types. The lagoon is generally a low-energy area, with lots of relatively muddy sediment. Small sand pockets may be deposited in lagoons during storms and around washover fans or tidal inlets. The coarser deposits within a lagoon tend to be small.

Poorly sorted silts and clays with scattered sand size particles of wind-blown quartz; erratically distributed thin stringers of moderate-to-well-sorted quartz sand; fauna often indicative of brackish or sometimes restricted conditions.

Washover lobe and flood tide delta sediments have some reservoir potential but sand quality cannot be expected to be consistent, and the sands are typically thin, erratically distributed, and are not continuous over long distances.

Linear Sand - Sand laid down as a long, narrow body. When linear sands produce hydrocarbons, the fields are often one or two well spacings wide. As a linear sand widens, it becomes a tabular sand body or tab sand.

Longshore Bar - A low, elongated sand ridge submerged at least by high tides, and built chiefly by wave action; occurring at some distance from, and extending generally parallel with the shoreline, and typically separated from the beach by an intervening trough.

Longshore Current - An ocean current caused by the approach of waves to a coast at an angle. It flows parallel to and near to the shore.

Longshore Drift - Material moved along the shore by a littoral or longshore current.

Low-Energy Environment - Regions of the coast with relatively quiet waters. These include much of the lagoonal setting and deeper-water areas, especially below wave base, where there is little current or breaking-wave action. Very fine-grained sediments tend to settle out quickly in these environments, producing shales and other non-reservoir-quality rocks. 
Marine Shelf Shale - Shale with some stringers of silt and/or poorly sorted sand; may become less shaly near contact with overlying distal bar facies; may contain scattered shells and thin shell layers; ample evidence of marine burrowing organisms.

Marsh - A water-saturated poorly drained area, intermittently or permanently water-covered, having aquatic and grasslike vegetation.

Massive Sand - Clean, well-sorted sand body with little obvious evidence of internal bedding. Barrier core sands are deposited in high-energy settings where the sediments are constantly being picked up, reworked and redeposited. The constant reworking tends to remove heterogeneities that would usually be recognized as bedding. Even though these sands appear uniform on logs and in cores, well-production histories from barrier core sands frequently show that there are numerous heterogeneities forming permeability barriers, even within well-sorted barrier core deposits.

Offshore Bar - (see longshore bar)

Offshore Barrier - (see barrier island)

Offshore Beach - A barrier island with no dunes present.

Open Shelf - A broad, relatively flat-bottomed, marine area, with relatively free circulation of water. Shelf-areas are covered by shallow to moderately deep water. The coarseness of the sediments depends on the local sources of supply. Clastic sediments will increase toward the shore and toward delta areas. In areas with little clastic influx, extensive carbonate deposits may form on the floor of the shelf.

Prograde, Progradation - Advance of a strandplain/barrier island complex seaward with time.

Ramp - A shallow, sloping marine area with relatively free circulation of water. A carbonateramp seafloor is very similar to an open shelf, but with a more steeply inclined, gradually deepening floor.

Restricted - Referring to water which does not circulate freely and may become periodically or consistently depleted in oxygen content.

Salt Dome - A domal structural feature caused by the buoyant vertical rise by plastic flow through a sedimentary section of deeply buried salt deposits.

Sequence - A conformable succession of genetically related strata bounded above and below by unconformities.

Sheet Sand - Sand laid down as a very broad body, generally thousands of feet or miles wide. Less widespread sands with a distinct linear trend are known as tabular sands or sand tabs. Very-narrow, elongate sand bodies are known as linear sands.

Shoreface - The narrow sloping sea-bottom zone extending seaward from the low-water shoreline.

Shoreline Barrier - (see barrier island)

Spit - A small point or low tongue of land commonly consisting of sand or gravel deposited by waves and longshore drift and having one end attached to the mainland with the other end terminating in open water. 
Storm Surge - An abnormal, sudden rise of sea level along an open coast during a storm, caused primarily by onshore wind stresses or atmospheric pressure reduction, resulting in water piled up against the coast.

Strandline - The shoreline, where the land first meets the water. Open-water strandlines tend to be high-energy settings and form good-quality reservoirs. Sheltered strandlines tend to be lower energy, muddy, and are poorer reservoir sites.

Strandplain - A prograded shore built seaward by waves and currents, continuous for some distance along the coast.

Subaerial - Exposed to the atmosphere or in the open air.

Submarine Bar - (see longshore bar)

Swale - Poorly sorted, thinly bedded silt and shale units; often with root traces; this facies may occur at any level in the subaerial part of the sequence.

Tabular Sand, Tab - Sand laid down as a relatively wide, but elongated body, wider than a linear sand, but more areally restricted than a sheet sand. Hydrocarbon fields which produce from sand tabs are generally at least three or four well spacings wide.

Tidal Inlet - A major channel followed by and/or formed by tidal currents; break in a barrier island or longshore bar where water is able to move out from river outlets or to flow back and forth from lagoons (in the barrier island case) to the open sea. In the strandplain/ barrier island environment, tidal inlets cut through the barrier core sediments and are perpendicular to both the shoreline and the long axis of the longshore bar, barrier island, or strandplain sediment bodies. The depositional setting around a tidal inlet is extremely complex, with localized, high-energy settings juxtaposed against muddy lagoon floors and clean, barrier core sands. Even when sands in a tidal inlet are in contact with the barrier core, subtle breaks in the sediment layers and attendant permeability barriers may make it difficult for hydrocarbons to flow from one sand body to the other.

Tidal inlet facies are quite variable but in general consist of one or more fining-upward sequences with sand and shell materials contained in lower cross beds and/or ripple beds (either of which may display bidirectional orientations). Deposits grade upward to finer sands and silt- to clay-size sediments with common shale drapes.

Tidal Currents - Water movements associated with and caused by rise and fall of water levels caused by tides.

Tidal Delta - (See ebb tidal delta and/or flood tidal delta)

Tidal Range - The difference in level or elevation of water between high and low tides at a given location.

Washover Fan - Sediment deposits washed over or eroded from a barrier island or longshore bar. Washover fans are formed of mixed materials, carried over the crest of the barrier island or longshore bar during exceptionally high-energy situations, like storms. These fans generally include much coarse-grained material. The deposits usually do not create good-quality, widespread reservoirs. 
Wave Base - The depth in shallow water to which wave action disturbs, sifts, and cleans the sand. Above wave base, sands are worked and reworked, cleaning the sediments, and potentially forming good reservoir deposits. As water depth increases, the amount of wave energy decreases, and sediments become muddier. 


\begin{tabular}{|c|c|c|c|c|}
\hline \multirow{3}{*}{\begin{tabular}{|c|} 
BTATE \\
ALABAMA \\
ABKANSAS
\end{tabular}} & FIELDNAME & AESERVOIRNAME & FORMATIONNAME & PLAY NAME \\
\hline & POLLARD & UPPEA TUSGALOOSA & LOWER TUSCALOOSA & CAETACEOUS \\
\hline & AITCHIE & BAKKEA SAND & GRAVES & UUPPERCAETACEOUS \\
\hline CALIFOANIA & ANT HILL & OLCESE & OLCESE & OLCESERILCHSS \\
\hline CALIFORNIA & ANTELOPE HILLS & WILLIAMS AREA EAST BLOCK AQUA & AQUA & TEMBLOR SS \\
\hline CALIFORNIA & BLACKWELLS CORNER & TEMBLOR AND AGUA & TEMBLOR & TEMBLOR SS \\
\hline CALIFOANIA & CAPITAN & COVAARUBIAS & SESPE EQUIVALENT & VAQUEROSIALGERIÁ STAAANDPLAIN. \\
\hline CALIFORNIA & CAPITAN & VAQUEROS & VAQUEROS & VAQUEROS/ALGERIA STRANDPLAIN \\
\hline CALIFORNIA & CAT CANYON WEST & ALEXANDER - MIOCENE & Sisouoc & SISQUOC SHELFSS \\
\hline CALIFOANIA & CONCEPTION OFFSHORE & SESPE EQUIVALENT & ALEGRIA & VAQUEROS/ALGERIA STRANDPLAIN \\
\hline CALIFOANIA & CUYAMA SOUTH & HOMAN & VAQUEROS & VAQUEROS (PAINTED ROCKS) STANDPLAIN SANDS \\
\hline CALIFOANIA & EDISON & VEDDER FAEEMAN & VEDDER \& FREEMAN.JEWETT & VEODEFUPYRAMID HILLS STRADPLAIN SS \\
\hline CALIFORNIA & GREELEY & VEODER & VEDDEA & VEODERUPYRAMID HILLS STRADPLAIN SS \\
\hline CALIFORNIA & JASMIN & CANTLEBERRY YEDDER (2 AREAS) & VEDDER & VEDDERUPYRAMID HILLS STAADPLAIN SS \\
\hline CALIFORNIA & KEAN BLUFF & MIOCENE & SANTA MARGARITA & SANTAMARGARITA STRANDPLAIN/DELTAIC SAND \\
\hline CALIFORNIA & MOUNT POSO & DORBEY AREA.VEDDEA & VEDDER & $\begin{array}{l}\text { VEDDEF/PYRAMID HILLS STRADPLAIN SS } \\
\end{array}$ \\
\hline CALIFORNIA & MOUNT POSO & UPPER VEDDEA & VEDDER & VEDDERUPYAAMID HILLS STRADPLAIN SS \\
\hline CALIFORNIA & OAKAIDGE & MLOCENE & TOPANGANAQUEROS & AON.DEFINED \\
\hline CALIFORNIA & PLACERITA & ALL AREAB & Pico & PICOTURBIDITE 88 \\
\hline CALIFORNIA & PLEITO & CREEK AREA & SANTAMARGAPITA & SANTA MARQARITA STAANDPLAIN/DELTAIC SAND \\
\hline CALIFOANIA & POSO CREEK & MCVAN AREA & ETCHEGOIN & SAN JOAQUINKEERN RIVER \\
\hline CALIFORNIA & ROSEDALE RANCH & LEADO & ETCHEQOIN & SAN JOAQUINKKERN RIVER \\
\hline CALIFOPNIA & ROUND MOUNTAIN & ROUND MTN. - JEWETT \& PYAAMID HILL & FPEEMANJ JEWET & VEDDEPUPYRAMID HILLS STRAOPLAIN SS \\
\hline CALIFORNIA & ROUND MOUNTAIN & COFFEE CANYON.VEDDER \& PYAAMID HILL & VEDDER \& PYAAMID HILLS & VEDDEFUPYRAMID HILLS STAADPLAIN SS \\
\hline CALIFORNIA & ROUND MOUNTAIN MAIN AREA & VEDDER & VEDDER & VEDDERVPYAAMID HILLS STRADPLAIN SS \\
\hline CALIFORNIA & RUSBELL RANCH & DIBBLEE SANDB & VAQUEROS & VAQUEROS (PAINTED ROCKS) STANDPLAIN SANDS \\
\hline CALIFORNIA & SAN ARDO & AURIONAC & MONTEREY & SAN ARDO.KING CITY SHELF SS \\
\hline CALIFOANIA & BAN ARDO & LOMBARDI & MONTEAEY & SAN ARDO.KING CITY SHELF SS \\
\hline CALIFORNIA & SHIELLS GANYON & EOCENE & LLAJAS & LLAJAS STRANDPLAIN SS \\
\hline CALIFORNIA & SUMMERLAND OFFSHORE & VAQUEROS & VAQUEROS & VAQUEROSIALGERIA STRANDPLAIN \\
\hline CALIFORNIA & TEJON GR - TEJON GRAPEVINE & WESTERN AREA $S$ & SANTA MARGARITA & SANTA MARGARITA STRANDPLAINIDELTAIC SAND \\
\hline CALIFORNIA & WAYSIDE CANYON & PLIOCENE & PICO & PICO STRANDPLLAIN/DELTAIC SB \\
\hline CALIFORNIA & WHEELER RIDGE & CENTAAL AREA COAL OIL CANYON.MAIN & EAUITVALE & BANTA MARGARITA STRANDPLAINIDELTAIC SAND \\
\hline CALIFORMIA & WHITE WOLF & AEEF RIDGE & AEEF AIDGE & SANTA MARGARITA STRANDPLAIN/DELTAIC SAND \\
\hline COLORADO & BOXEP & D SAND & DAKOTA & DENVER BASIN D J BANDS \\
\hline COLORADO & MOFFAT & DAKOTA & DAKOTA & NWW COCRETACEOU S DAKOTA CHANNEL SANDS \\
\hline COLORADO & PRICE GAAMPS & MORAIBON & DAKOTA.MOAAISON & SAN JUAN BASIN DAKOTA.MORAISON SANDS \\
\hline COLORADO & SABER & D SAND & DAKOTA & DENVER BASIN D.J SANDS \\
\hline COLORADO & SABER & DSANO & DAKOTA & DENVER BASIN D.J SANDS \\
\hline COLORADO & WILSON CAEEK & MORRISON SAND & MORRISON & UINTA'PICEANGE BASIN MORAISON SANDS \\
\hline ILLINOI8 & DALE CONSOLIDATED & AUXVABES & AUXVABES & UPPER VALMEYERAN \\
\hline ILLINOIS & JOHNBONVILLE CONBOLIDATEO & AUXVASES & AUX VABES & UPPER VALMEYERAN \\
\hline IILLINOI8 & LAWAENCE & JACKSON & FRAILEYS & CHESTERIAN TIDE.DOMINATEO DELTA \\
\hline ILLINOI8 & LAWRENCE & AUXVABES & AUXVASES & UPPER VALMEYERAN \\
\hline IILINOI8 & LOUDEN & CYPRESS & CYPAES8 & CHESTERIAN STRANDPLAIN \\
\hline ILLINOIS & MAIN CONSOLIDATED & BAMPLE & RIDENHOWER & CHESTERIAN TIDE.DOMINATEO DELTA \\
\hline ILLINOIS & PATOKA EABT & CYPREB8-BENOIBT & CYPAES8 & CHESTERIAN STAANDPLAIN \\
\hline ILLINOI8 & BT. JAMES & CYPAEBS & CYPRESS & CHESTERIAN STAANDPLAIN \\
\hline INDIANA & CABORN CONSOLIDATEO & MANBFIELD & MANSFIELD & PENNSYLVANIAN DELTAIC SAND \\
\hline INDIANA & GAIFFIN CONSOLIDATED & TOTAL FIELD & CYPAESS & CHESTEAIAN SAND PLAY \\
\hline INDIANA & HEUSLEA CONSOLIDATED & MANGFIELD & MANSFIELD & PENNSYLVANIAN DELTAIC SAND \\
\hline KANBAB & OTis & AEAQAN & AEAGAN & CENTRAL KANSAS UPLIFT \\
\hline KANBAB & RAY & AEAOAN & AEAGAN & CENTAAL KANSAS UPLIFI \\
\hline LOUIBIANA & CHANDELEUR 6OUND BLOCK 25 & BB AA BAND & LA & MOCENE \\
\hline LOUISIANA & TEPETATE, WEST & MILLER & MILLER BAND & QJGOCENE \\
\hline LOUIBIANA & VINTON & UPPER MIOCENE & UPPPER MIOCENE & MOCENE \\
\hline LOUISIANA & WELSH & CAMEPINA & CAMEPINA & LAGOCGENE \\
\hline
\end{tabular}




\begin{tabular}{|c|c|c|c|c|}
\hline 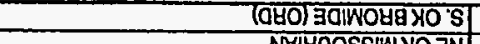 & 3alWoya & 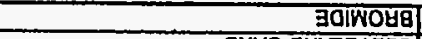 & $7710 \forall W$ & 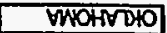 \\
\hline & 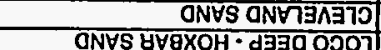 & ONB8 ONVIBAGT & HINOSWTI $\exists N O T$ & WWOHAOO \\
\hline NEIYNOSSINDO S & 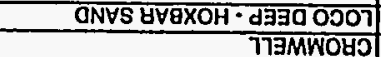 & 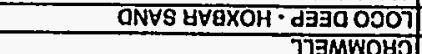 & LOIHLSIO O007) & BWOFODO \\
\hline 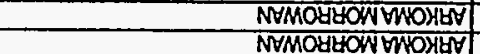 & 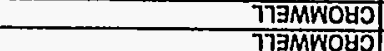 & 719MWO女5 & 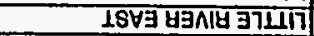 & WWO+NO+O \\
\hline NFMOYHOW WWOYHA & 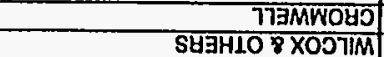 & 77 MMKOY & ४日3กाष & WWOANDO \\
\hline XOJTWWHOILVIAGTONIWES & 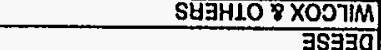 & SHAH10 8XOJ7IM & BgnIष 971117 & WWONOFO \\
\hline 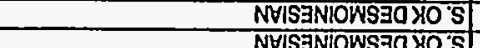 & $\begin{array}{l}35930 \\
35390\end{array}$ & 33930 & HIHONNOST & BWOAVDTO \\
\hline NEISENIOWSZOXOST & 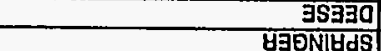 & 3S330 8'UVQXOH'OOLOINOd & XONY & WWotwoto \\
\hline NHESONIYdS XO'S & 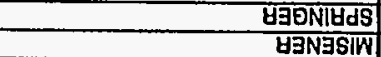 & U3ONIYdS & XONYY & WWOHNOA \\
\hline NESOIV PO TVYLNES & 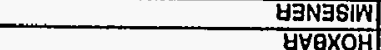 & NOLNOH ONY YINBSIN & मПभО्डम & WWO+Noto \\
\hline NAIYNOSSINHO'S & 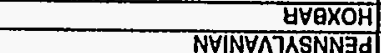 & उSت30.4VGXOH & ISVG मIMAH & 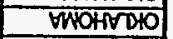 \\
\hline 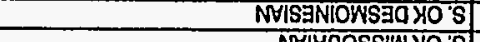 & 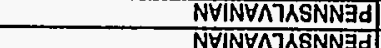 & NEINZNTKBNNEd & ILIMEH & BWOFVOLO \\
\hline NAIEROSSINXO'S & 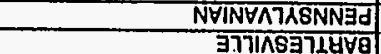 & NVINYATASNNABU & NOLOTVaH & WWOHFOTO \\
\hline S8 NVINIOWSZOXO BN & 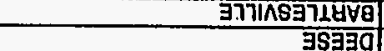 & J771169718 & छाषHसाก & Wortioto \\
\hline 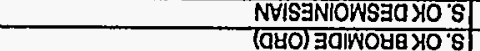 & 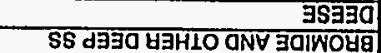 & 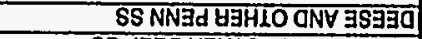 & ONABINEATOO & WWOHFOO \\
\hline 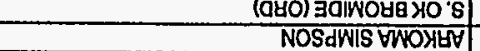 & 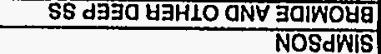 & SS daga \&BHLO ONY JOINOYG & ONABINGOTOO & DWOAFOtO \\
\hline 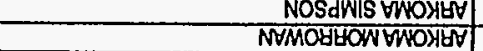 & $\begin{array}{l}\text { NOSdWIS } \\
77 \text { MWOYO }\end{array}$ & NOSdWIS Y VTOIN & Sप119 & 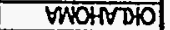 \\
\hline 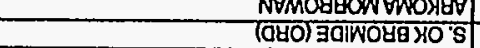 & $\frac{77 \exists M W D Q 80}{\text { NOSdWIS }}$ & Т7ЕМКО४У & 81119 & Whothoto \\
\hline 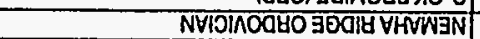 & $\begin{array}{r}\text { NOSdWIS } \\
\text { XOJIM QNZ ONY NOSdWIS }\end{array}$ & 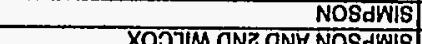 & NOSHa日EOY.VTOS & BWOANDHO \\
\hline 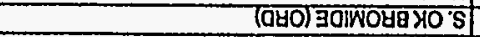 & 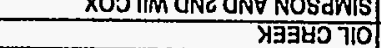 & 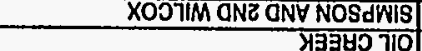 & IS 9 M ONOWOG & WWOHEOTO \\
\hline 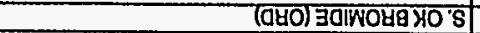 & 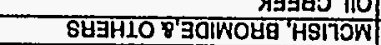 & 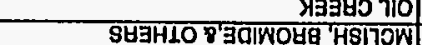 & $\exists N \sin \theta 0$ & BWORVAO \\
\hline NGMOZHOW WWOXEAT & 77घMWO80 & 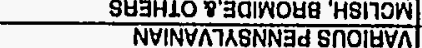 & anVIGagwno & WHOWVOOO \\
\hline 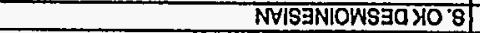 & 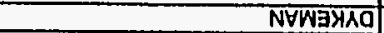 & $\frac{\text { NYINYATASNNGd SNOIUYN }}{\text { NEWBYAO }}$ & 77 घMWOप: & BMotrivato \\
\hline W0101NOd\%S & प्रषOA 0ज甘 & 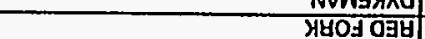 & 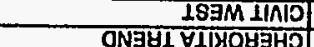 & BYOHVDO \\
\hline NYMOUEOW WWOXEA & 7าझMWO४० & 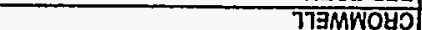 & 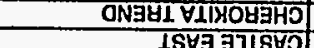 & DYNOHFDO \\
\hline NVISaNIOWS & (G89Ba) NVING $\Lambda 7 K B N N=$ & 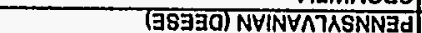 & ISY9 & WWOFजिए। \\
\hline XOJTWWEOIIVAGTONIWGS & 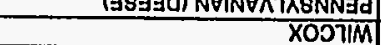 & 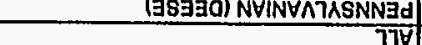 & म०णष्ष & Grotaroto \\
\hline 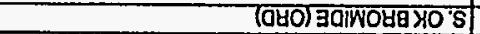 & $\frac{\text { Xo5nM }}{\text { בalWoyg }}$ & 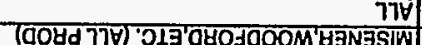 & S037Mog & BWOFNOAO \\
\hline 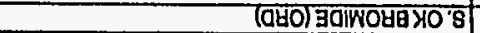 & בalWora & 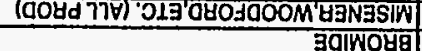 & HL४ОMSヨาAY & DMo+rodo \\
\hline ANMOALOW WWOXEA & 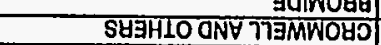 & 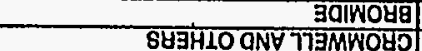 & IHOVdV & BHOHVOLO \\
\hline 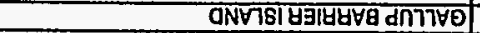 & dก7Tष & 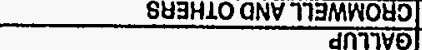 & I016L8IONAาT & BWOHNOWO \\
\hline 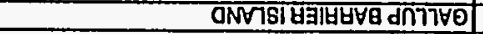 & dกา7v0 & $\frac{\text { dก77vo }}{\text { dก77vo }}$ & O4910 & CONGWMEN \\
\hline 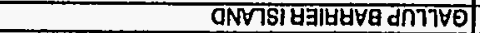 & 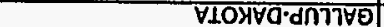 & 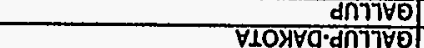 & 8YOOOY ANFW & DOKGWMEN \\
\hline 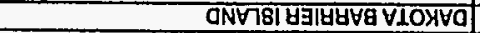 & & 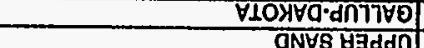 & I8EM HIIEONIT| & COXONMEN \\
\hline 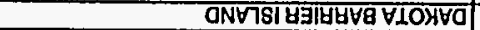 & ONFS yaddi & $\begin{array}{ll}\text { anVS Hadd } \\
\text { ONGS }\end{array}$ & HLOOS HVdSOH & OOXENMEN \\
\hline 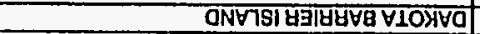 & 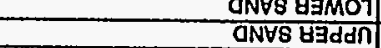 & 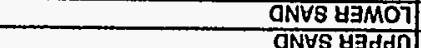 & HINOS HVABOH & DOXEWMENA \\
\hline QNVISIYIIULVO dกTIVO & $\frac{\text { anvs baddn }}{\text { dnT7Vo }}$ & anVS YEdd & HYASOH & OOKGWMEN \\
\hline बNล & $\frac{d \cap 77 v 0}{d ก 7780}$ & $\begin{array}{l}\text { dח77VD } \\
\text { dก7778 }\end{array}$ & 3OHSA34OH & OODENMBN \\
\hline 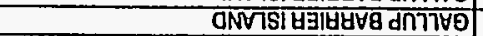 & 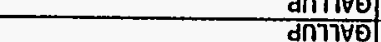 & dח7780 & Oplüosa & OSXINMAN \\
\hline 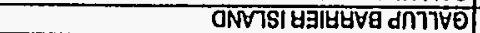 & $\frac{\text { dmive }}{\text { dnTivo }}$ & वกา7ष0 & 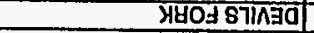 & OOXXWMSN \\
\hline 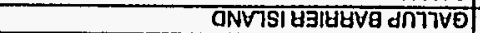 & 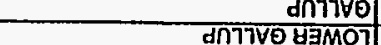 & dกา7vอ & VHO.VHO & OOXSWMEN \\
\hline 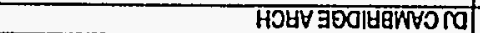 & 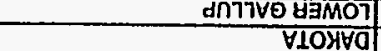 & 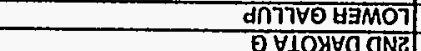 & 11810 & COXXWMEN \\
\hline 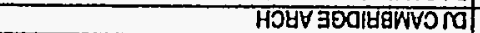 & 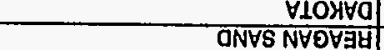 & OVIOXVOANE & MOYVAdS & पHSVZREN \\
\hline 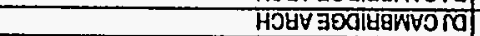 & $\begin{array}{l}\text { ONVS NHOVAY } \\
\text { ONES NNAd TVSVG }\end{array}$ & NYOYaY & MOT7OH К & BSBVZGAN \\
\hline HOBY JOaIBEWYO Na & $\begin{array}{r}\text { QNYS NNAd 7VSVG } \\
\text { VIOYVO }\end{array}$ & QNGS NVINVATKSANABd & 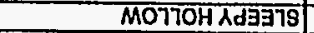 & BSBZAGN \\
\hline HOUY soalyaWrona & 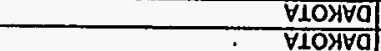 & ONVST & NO1Z7อNIS & VAS W \\
\hline HOHY JDOIUGWHO CO & 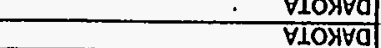 & 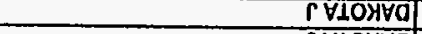 & 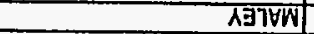 & BARVAQBN \\
\hline 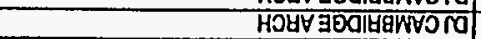 & 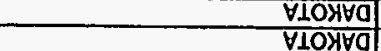 & SVIOXYO & 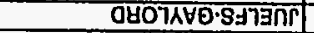 & V्XSVZQAN \\
\hline 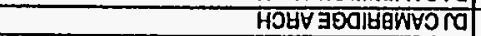 & 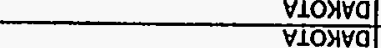 & 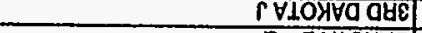 & NEWSINAH & DSBOABN \\
\hline HOY 3DOIU9WYOM & 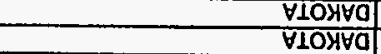 & 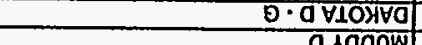 & NYWEOO & DASVZESN \\
\hline 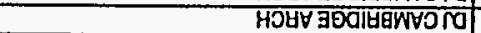 & $\begin{array}{ll}10 x+9 \\
\forall 10 x \forall a \mid\end{array}$ & $\begin{array}{r}\text { O AaOnW } \\
\text { ONES }\end{array}$ & म्र०00 & WRBVABan \\
\hline SAVGI TVUחIONEIS VNVINOW TVUINAO & 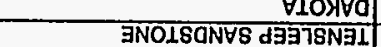 & 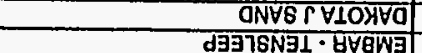 & NIHOTIV & BHSVAGIN \\
\hline 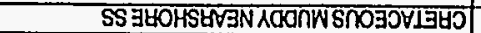 & & d9978NE1-8VEWG & NiBva哽 & BNINOW \\
\hline AV7d OIHAVYOILVUIS YSOOTVOSกL HAMOT| & VSOOTVOSOL HGMOT & $\begin{array}{r}\text { RagnW } \\
\text { g. }\end{array}$ & 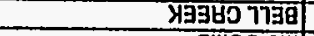 & BNYINOW \\
\hline 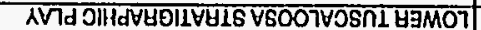 & VSOOTVOSกI UEMOT & 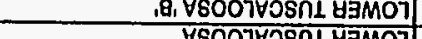 & EW00 JW & Iddis8ISBIW| \\
\hline JWVN $\lambda \forall 7 d$ & IW $\forall N$ NOIL $\forall W H O A$ & YSOOTVOSก L & OTIIANYQD & Iddis8issin \\
\hline & & & IWUN a7ala & 31V16 \\
\hline
\end{tabular}




\begin{tabular}{|c|c|c|c|c|}
\hline STATE & FIELD NAME & AESERVOIR NAME & FORMATION NAME & PLAYNAME \\
\hline OKLAHOAMA & MIDWELL & KEYES & KEYES & SE ANADARKO WOLFCAMPIAN \\
\hline OQAHOANA & OCONEEEAST & OIL CAEEK & OIL CREEK & ARKOMA SIMPSON \\
\hline ONLASTOMA & OKLAHOMACITY & LOWER SIMPSON & LOWER SIMPSON & NEMAHA FIDGE ORDOVICIAN \\
\hline OHLAHOMA & OKLAHOMA CITY & WILCOX & WILCOX & NEMAHA FIDGEORDOVICIAN \\
\hline OLAAHOMA & OVEARROOK BOUYH & DEESE & DEESE & 6.OKDESMOOINESIAN \\
\hline OKLAHOAMA & PAPOOSE & CROMWELL & CROMWELL & ARKOMAMOARAOWAN \\
\hline OHCAHOMA & PAULS VALLEY & BASAL PENNSYLVANIAN & BABAL PENNSYLVANIAN & S. OKDESMOINESIAN \\
\hline OTLAHOMA & PAULS VALLEY SE & OIL GREEK (PROJECT) & OIL CAEEK (PROJECT) & S. OKBROMIDE (ORD) \\
\hline OQALOOMA & POSTLE & MORROW & MORROW & SE ANADARKO WOLFCAMPIAN \\
\hline OKLASOAMA & RED BANK & DUTCHEA & DUTCHEP & SE CHAUTAUQUA \\
\hline OHLAYOMA & BEMINOLE & WILCOX \& OTHER SANDS & WILCOX\& OTHER SANDS & SEMINOLE PLATFORM WICOX \\
\hline OAOAHOMA & SEMINOLE WEST & WILCOX & WILCOX & SEMINOLE PLATFORM WILCOX \\
\hline OQAHOMA & SHO.VEL.TUM & DEESE & DEESE & 8. OKDESMOINESIAN \\
\hline OAQAHOMA & SHO.VEL-TUM & HOXQAR & HOXBAR & S.OKMISSOURIAN \\
\hline OKCAHOMA & SOLOIER CAEEK & cIsco & CISCO & S.OKVIRGILIAN \\
\hline OCALTONA & BOONER TREND & LAYTONAND OTHER 88 & LAYTONAND OTHER 88 & ANADARKO BASIN MISSOURIAN \\
\hline OCALOMA & THACKERVILLE NOATH & DEESE & DEESE & 8.OKDESMOINESIAN \\
\hline OKLAHOMA & TONKAWA & WILCOX & WILCOX & NEMAHARIDGE ORDOVICIAN \\
\hline OKRAHOMA & WATCHORN EABT & WILCOX & WLLCOX & NE OK MISSISBIPPIAN \\
\hline OERATOMA & WEWOKA DISTAIOT & CROMWELL & CROMWELL & ARKOMA MOAROWWAN \\
\hline PENNSYLVANIA & FOSTER-AENO.OIL CITY & MERAMEC & VENANGO & VENANGO GROUP SIRANOPLAIN BAA AND BEACH \\
\hline TEXAS & ALBA & & TX & CAETACEOUS, SALT.RELATED \\
\hline TEXAS & AMELIA & FALO & Faio & FAIO (BUNA) BARAIEPUSTRANDPLAIN \\
\hline IEXAS & ARMSTRONG & BAENNAN & BAENNAN & JACKSON BAAAIEPISTANDPLAIN \\
\hline IEXAS & AFMBTRONQ & BRENNAN & BAENNAN & JACKSON BARAIEPUSTANDPLAIN \\
\hline IEXAS & ARNOLD DAVID & CHAPMAN SAND & CHAPMAN SAND & FAIO STANDPLAIN \\
\hline TEXAS & AVIATORS & MIAANDO SAND & MIRANDO 8AND & JACKSON BAARIERVSTANDPLAIN \\
\hline TEXAS & BALOWIN & & TX & FAIO STANDPLAIN \\
\hline TEKAS & BEAUMONT & & TX & FFIO (BUNA) BAARIERUSTAANDPLAIN \\
\hline TEXAS & BENAVIDES & & $T x$ & JACKSON BARAIERYSTANDPLAIN \\
\hline TEXAS & BENAVIDES & & $T X$ & JACKSON BARRIERUSTANDPLAIN \\
\hline TEXAS & BLEESSING & $\overline{F \cdot 14 \cdot B}$ & $F \cdot 14 \cdot 8$ & FRIO STANDPLAIN \\
\hline IEXAS & ELESBINO & $F \cdot 14 \cdot B$ & $F \cdot 14 \cdot 8$ & FAIO STANDPLAIN \\
\hline TEXAS & BLESSING & F.3 & $\mathbf{F} \cdot \mathbf{3}$ & FAIO STANDPLAIN \\
\hline TEXAS & BLESSING & F.3 & E.3 & FAIO STANDPLAIN \\
\hline IEXAS & BL.OOMINGTON & 4600 & 4600 & FAIO STANDPLAIN \\
\hline TEXAS & BONNIE VIEW & BONNIE VIEW & BONNIE VIEW & FAIO STANDPLAIN \\
\hline IEXAS & CAMPANA, 8OUTH & & TX & JACKSON BARRIER/STANDPLAIN \\
\hline TEXAS & CAMPANA, BOUTH & & TX & MISCEELANEOUS \\
\hline TEXAS & CARTHAGE & BUANETT SAND & BUANETT SAND & CRETACEOUS, SALT.RELATED \\
\hline IEXAS & CARTHAQE & & IX & CRETACEOUS, SALT-RELATED \\
\hline TEXAS & CEORO HILL & COLE BAND & COLE BAND & JACKBON BAARIERISTANDPLAIN \\
\hline TEXAS & CHAPEL HILLL & FREDRICKSBURG GROUP & FAEDAICKGBUARG GAOUP & CRETAGEOUS, SALT.RELATED \\
\hline TEXAS & CHARAMOUSCA, WEBT & WILCOX2 & $T X$ & JACKSONBARAIER/STANDPLAIN \\
\hline IEXXA & COKE & PALUXY & PALUXY & CAETACEOUS, BALT.AELATED \\
\hline TEXAS & COKE & SUB.CLAAKBVILLE & SUB.CLARKSVILLE & CRETACEOUS, BALT.HELLATED \\
\hline TEXAS & COLE, WEST & MIRANDO SAND & MIAANDO SAND & JACKSON BARAIERISTANDPLAIN \\
\hline TEXAS & COLETTO CREEK & $2800^{\prime} \mathrm{POOL}$ & 2800 SAND & MMISCEULANEOUS \\
\hline TEXAS & CONOCO DRISCOLL & TUPPER FIRST GOVERNMENT WELLS SAND & UPPER FIRBT GOVERNMMENT WELL 8 SAND & JACKGON BARAIER/STANDPLAIN \\
\hline TEXAS & CORPUB CHAIBTI & & $7 x$ & FRIO BTANOPLAIN \\
\hline TEXAS & CORBICANA & SHALLOW & SHALLOW & MISCELLANEOUS \\
\hline IEXAS & EAQLE HILLL. & & $T x$ & JACKBON BARRIERISTANDPLAIN \\
\hline TEXAS & ELPAR & $F \cdot 07, E$ & F.07,E & FRIO BTANDPLAIN \\
\hline TEXAS & ELPAR & F.07,EABT & $\overline{T X}$ & FAIO STANDPLAIN \\
\hline TEXAS & ENCINO & 6400 8AND & B400 SAND & FRIO STANDPLAIN \\
\hline TEXAS & ESCOBAS & MIRANDO & MIRANDO & JACKSON BARPIERISTANDPLAIN \\
\hline
\end{tabular}




\begin{tabular}{|c|c|c|c|c|}
\hline STATE & FIELD NAME & BESERVOIR NAME & FOAMATION NAME & PLAYNAME \\
\hline IEXAS & EZZELL & & - & JACKSON BARAIERUSTANDPLAIN \\
\hline IEXAS & FITZSIMMONS & & $\overline{I X}$ & JACKSON BARRIERUSTANDPLAIN \\
\hline IEXAS & FLOUA BLUFF, EAST & MASSIVE, UP. & MASSIVE, UP. & FFIO STANDPLAIN \\
\hline TEXAS & FOAEST HILL & HARAIS SAND (B.F SEQMENTS) & HARRIS SAND (B.F SEGMENTS) & CRETACEOUS, SALT.RELATED \\
\hline TEXAS & FAANCITAB, NORTH & & $T \times$ & FRIO STANDPLAIN \\
\hline TEXAS & GANADO & & FX & FAIO STANDPLAIN \\
\hline IEXAS & OANADO DEEP & HULTQUIST & HULTQUUIST & FRIO STANDPLAIN \\
\hline TEXAS & GANADO OEEP & & IX & FAIO STANOPLAIN \\
\hline TEXAS & GANADO, WEST & 4700 ZONE & $4700 \mathrm{ZONE}$ & FRIO STANDPLAIN \\
\hline IEXAS & GOVEANMENT WELL 8 NORTH & GOVERNMENT WELLS SAND & GOVERNMENT WELLS SAND & JACKSON BARRIER/STANDPLAIN \\
\hline IEXAS & GOVERNMENT WEULS, SOUTH & GOVERNMENT WELLS & GOVERNMENT WELLS SAND & JACKSON BARRIER/STANDPLAIN \\
\hline IEXAS & GAETA & 4400 & 4400 & FAIO STANDPLAIN \\
\hline EXXAS & HAM GOSSETT, EAST & & WOODBINE & WOODBINE FAULT LINE \\
\hline TEXAS & HEYSER & 5400 NO. 2 & $6400 \mathrm{NO} .2$ & FAIO STANDPLAIN \\
\hline IEXAS & HEYSER & 6400 NO. 3 & $6400 \mathrm{NO} .3$ & FRIO STANDPLAIN \\
\hline TEXAS & HEYSER & & $7 x$ & FAIO STANDPLAIN \\
\hline IEXAS & HIITS & PAULUXXY & PALUXY & CAETACEOUS, SALT-RELATED \\
\hline TEXAS & HOFFMAN & LOMA NOVIA 2730 & LOMA NOVIA 2730 & JACKSON BARAIERSSTANDPLAIN \\
\hline TEXAS & HOFFMAN & & $T x$ & JACKSON BARAIEPUSTANOPLAIN \\
\hline TEXAS & JEENNINGS & MIRANDO & MIRANDO & JACKSON BAARIERUSTANDPLAIN \\
\hline TEXAS & JENNINOS, WEST & 3000 8AND & 3000 SAND & JACKSON BAARIEIEUSTANDPLAIN \\
\hline TEXAS & KERENS, SOUTH & WOODaINE & WOODBINE & WOODBINE FAULTLLINE \\
\hline TEXAS & LAROSA & 6800 SAND & 6900 SAND & FAIO STANDPLAIN \\
\hline TEXAS & LA WARD, NOATH & FA10 & FAIO & FAIO STANDPLAIN \\
\hline TEXXS & LAKEPASTURE & FT.668 & FT.568 & FAIO STANDPLAIN \\
\hline TEXAS & LAKE PASTUAE & H.A4O SAND & H. 440 SAND & FAIO STANDPLAIN \\
\hline IEXAS & LAS ANIMAS.LEFEVAE & COLE & COLE & JACKSON BARAIEPUSTANDPLAIN \\
\hline TEXAS & LOLITA & MARQINULINA ZONE & MARQINULINA ZONE & FRIO STANDPLAIN \\
\hline IEXAS & LOLITA & TONEY ZONE & TONEY ZONE & FA1O STANDPLAIN \\
\hline IEXAS & LOLITA DEEP & 4.WAY ZONE & 4.WAY ZONE & FAIO STANDPLAIN \\
\hline IEXAS & LOMA NOVIA & LOMA NOVIA SAND & LOMA NOVIA SAND & JACKSON BAFRIER/STANDPLAIN \\
\hline IEXAS & LONDON GIN & DOUGHTEA SAND & DOUGHTER SAND & FAIO STANDPLAIN \\
\hline TEXAB & LOPEZ & MIRANDO SAND & MIRANDO SAND & JACKSON BARAIER/STANDPLAIN \\
\hline TEXAS & LOUISE & & IX & FAIO STANDPLAIN \\
\hline TEXAS & LOVELLS LAKE & FAIO2 & FRIO 2 & FRIO (BUNA)BARRIER/STRANDPLAIN \\
\hline IEXAS & LUCULLE & HOCKLEY, UPPEA & HOCKLEY, UPPEA & JACKSON BAARIER/STANDPLAIN \\
\hline IEXAS & LUNDELL & COLE SAND & COLE SAND & JACKSON BARPIEPUSTANDPLAIN \\
\hline TEXAS & LUNDELL & PETTUS & PETTUS & JACKSON BARRIERISTANDPLAIN \\
\hline TEXAS & LUNDELL & PETTUS & PETUUS & JACKSON BAFRIEFISTANDPLAIN \\
\hline IEXAS & MAGNET WITHERS & FAIO POOL & FRIOPOOL & FRIO STANDPLAIN \\
\hline IEXAS & MANZIEL & PALUXY & PALUXY & CAETACEOUS, SALT-RELATED \\
\hline IEXAS & MAAKHAM N.GAY GITY,N & CORNELIUS & CORNELIUS & FRIO STANDPLALIN \\
\hline TEXAS & MAAKHAM, NOATH & CORNELIUS & CORNELIUS & FRIO STANDPLAIN \\
\hline IEXAS & MAAKHAM NORTH - BAY CITY NORTH & EAST CAYCE & EABT CAYCE & FALO STANDPLAIN \\
\hline IEXAS & MARKHAM, NORTH - BAY CITY NOATH & WEST CAYCE & WEST CAYCE & FRIO STANOPLAIN \\
\hline TEXAS & MAAKHAM, NORTH - BAY CITY, NORTH & WEST CORNELIUS & WEST CORNELIUS & FAIO STANDPLAIN \\
\hline IEXAS & MARKH AM, NORTH-BAY CITY, NOATH & CAALSON & CARLSON & FRIO STANDPLAIN \\
\hline IEXAS & MARKHAM, NORTH-BAY CITY, NORTH & CAYCE & CAYCE & FRIOSTANDPLAIN \\
\hline TEXAS & MARY ELLENOCONNOR & Fa.40 SAND & FO.40 SAND & FAIO STANDPLAIN \\
\hline IEXAS & MARY ELLEN OCONNOR & FQ. 40 SAND & FQ.40 SAND & FAIOSTANDPLAIN \\
\hline IEXAS & MARY ELLEN OCONNOR & FS.98 & FS.86 & FFIO STANDPLAIN \\
\hline TEXAS & MAURBRO & MARGINULINA & MARGINULINA & FAIO STANDPLAIN \\
\hline IEXAS & MC FADDIN & $4400^{\circ}$ & $4400^{\circ}$ & FAIO STANDPLAIN \\
\hline IEXAS & MEXIA & WOODBINE & WOODBINE & WOODBINE FAULTLINE \\
\hline TEXAS & MIDFIELOS & & $7 x$ & FRIO STANDPLAIN \\
\hline IEXAS & MIDWAY LAKE & & TX & CRETACEOUS, SALT.AELATED \\
\hline
\end{tabular}




\begin{tabular}{|c|c|c|c|c|}
\hline BTATE & FIELDNAME & RE8ERVOIRNAME & FOAMATION NAME & PLAYNAME \\
\hline TEXAS & MIRANDO CITY & MIRANDO BAND & MIRANDO SAND & JACKSON BARAIER/STANDPLAIN \\
\hline IEXAS & MUSTANO IBLAND & B SAND & B SAND & FRIO STANDPLAIN \\
\hline TEXAS & MUSTANG ISLAND & $7 \cdot A$ & $7 \cdot A$ & FAIO STANDPLAIN \\
\hline TEXAS & MUSTANG ISLAND & B BAND & OSAND & FAIO STANDPLAIN \\
\hline TEXAS & MUSTANG ISLAND & O SAND & OSAND & FRIO STANDPLAIN \\
\hline FEXAS & NEW HOPE & HILL SAND & HILL SAND & CRETACEOUS, SALT-AELATED \\
\hline TEXAS & NEWHOPE & PITTSBURG & PITISBUAG & CRETACEOUS, SALT-RELATED \\
\hline TEXAS & NOME & ALL SANDO & ALL SANDS & FAIO (BUNA) BAARIERUSTRANOPLAIN \\
\hline IEXAS & NOME & X. SAND & X-SAND & FAIO (BUNA) BARRIERUSTRANDPLAIN \\
\hline TEXAS & ODEM & $6700 \mathrm{~B}$ & $6700 \mathrm{~B}$ & FAIO STANDPLAIN \\
\hline TEXAS & ODEM & $6700 \mathrm{~B}$ & $6700 \mathrm{~B}$ & FAIO STANDPLAIN \\
\hline TEXAS & ODEM & ODEM & ODEM & FAIO STANDPLAIN \\
\hline TEXAS & OHERN & PETTUS & PETTUS & JACKSON BARRIER/STANDPLAIN \\
\hline TEXAS & OILTON & BRUNI & BRUNI & JACKSON BARRIERISTANDPLAIN \\
\hline TEXAS & OLDOCEAN & ARMSTRONO & ARMSTRONO & FAIO BTANDPLAIN \\
\hline TEXAS & OLDOCEAN & CHENAULT & CHENAULT & FRIO STANDPLAIN \\
\hline TEXAS & OLDOCEAN & & $\mathrm{TX}$ & FAIO STANDPLAIN \\
\hline TEXXS & PETTUS & & PEETTUS & JACKSON BARRIERUSTANDPLAIN \\
\hline TEXAS & PHEASANT, SOUTHWEST & 01500.1 & B160 BAND & MISCEULANEOUS \\
\hline TEXAS & PHOENIX LAKE & & $T x$ & MISCELLANEOUS \\
\hline IEXAS & PICKETR PIDGE & FalO & FAIO & FAIO STANDPLAIN \\
\hline TEXAS & PIEOAELUMARE & QOVEANMENT WELL, S SAND & QOVERNMENT WELL 8 SAND & JACKSON BARRIER STANDPLAIN \\
\hline IEXAS & PITSSBUAOH FIELD & PITTBBURAH SAND UNIT & PITTSBURQH BAND UNIT & CAETACEOUS, SALT-AELATED \\
\hline TEXAS & PLYMOUTH & & HEEP & FRIO STANDPLAIN \\
\hline TEXAS & POATILA & 7300 BAND & 7300 BAND. & FAIO BTANDPLAIN \\
\hline TEXAS & POATILLA & 7400 BAND & 7400 SAND & FRIO STANDPLAIN \\
\hline TEXAS & PORTILLA & B100 SAND & 8100 SAND & FRIO STANOPLAIN \\
\hline IEXAS & POWELL & & WOODEINE & WOODBINE FAULT UNE \\
\hline IEXAS & PAADO & COMBINED ZONES & COMEINED ZONES & JACKSON BARRIERUSTANDPLAIN \\
\hline TEXAS & PAADO & COMBINED ZONES & COMBINED ZONES & JACKSON BARRIERIBTANDPLAIN \\
\hline TEXAS & PAADO & LOMA NOVIA MIDDLEIII & LOMA NOVIA MIDDLEII & JACKSON BARAIER/BTANDPLAIN \\
\hline TEXAS & QUITMAN & & PALUXY & CRETACEOUS, BALT.AELATED \\
\hline TEXAS & QUITMAN & SUB.CLARKBVILLE & SUB.CLARKSVILLE & CAETACEOUS, BALT.AELATED \\
\hline TEXAS & QUITMAN, NORTHWEST & PALUXY & PALUXY & CAETACEOUS, SALT.RELATED \\
\hline TEXAB & RANDADO & & $T x$ & JACKSON BAAFIERVSTANDPLAIN \\
\hline TEXAS & REFUGIO HEARD & AREA & AAREA & FRIO STANDPLAIN \\
\hline TEXAS & AEFUGIO NEW & 6200 FB1 & $6200 \mathrm{FB1}$ & FRIO STANDPLAIN \\
\hline TEXAS & AEFUQIO.FOX & & $7 x$ & FRIO BTANDPLAIN \\
\hline TEXA8 & HOCHE & "C' SAND & C. SAND & FAIO STANDPLAIN \\
\hline IEXAS & BAND FLAT & & PALUXY & CRETACEOU B, BALT.RELATED \\
\hline EXXAS & SANDUSKY & OJLCAEEK SAND & OIL CAEEK SAND & MISCELLANEOUS \\
\hline IEXAS & SAXET & DEEP & $5 x$ & FAIO STANDPLAIN \\
\hline EXXAB & SAXET, DEEP & & DEEP & FRIO STANDPLAIN \\
\hline TEXAS & SENITA & HOCKLEY,JACKSON & HOCKLEY,JACKSON & JACKBON BAARIER/STANDPLAIN \\
\hline TEXAS & BEVEN BIBTEA8 & GOVT. WELLLS BAND & GOVT. WELLS SAND & JACKSON BARRIERUSTANDPLAIN \\
\hline TEXAS & SEVENTY.SIX, BOUTH & & $7 x$ & JACKSON BARFIER/STANDPLAIN \\
\hline TEXAS & SHAMBURGER LAKE & PALUXY & PALUXY & CAETACEOUS, BALT.RELATED \\
\hline TEXAB & BLOCUM & CARRIZO BAND & CAARIZO SAND & CAETACEOUS, SALT.RELATED \\
\hline TEXAS & GUGAR VALLEY & LAUAENCEA & LAUAENCE A & FRIO STANDPLAIN \\
\hline TEXA8 & TAFT & 4000' BAND & 4000' BAND & FAIO BTANDPLAIN \\
\hline TEXAS & TOMO'CONNOA & CATAHOULA.FRIO-MIOCENE & CATAHOULA.FAIO-MIOCENE & FRIO STANDPLAIN \\
\hline TEXAS & TOMOCONNOA & 6500 & 6000 & FRIO 8TANDPLAIN \\
\hline TEXAS & TOMOCONNOR & 4400 BAND & IA400 SAND & JFRIO STANDPLAIN \\
\hline
\end{tabular}




\begin{tabular}{|c|c|c|c|c|}
\hline STATE & FIELDNAME & RESERVOIRNAME & FOAMATION NAME & PLAYNAME \\
\hline IEXAS & TOMOCONNOR & A500 GRETA MASS. & A500 GRET M MASS. & FRIO STANOPLAIN \\
\hline TEXAS & TOMOCONNOR & 6400 SAND & 6400 SAND & FAIO STANDPLAIN \\
\hline TEXAS & TRIXLIZ & WOODBINE B & WOODBINE B & WOODBINE FAULT TINE \\
\hline TEXAS & TRIXLIZ & WOODBINE D & WOODBINED & WOODGINE FAULT LINE \\
\hline IEXAS & VOLPE & LOPE2 & LOPEZ & $\begin{array}{l}\text { JACKSON BARAIEPISTANDPLAIN } \\
\end{array}$ \\
\hline IEXAS & WEST RANCH & $41 \cdot A$ & $41-\mathrm{A}$ & FRIO STANDPLAIN \\
\hline IEXAS & WEST RANGH & $98 \cdot A$ & $88 \cdot \mathrm{A}$ & FAIO STANDPLAIN \\
\hline TEXAS & WEST RANCH & QLABSCOCK & QLASSCOCK & FRIO STANDPLAIN \\
\hline TEXAS & WESTRANCH & GAETA BAND & GAETA BANO & FFIO STANDPLAIN \\
\hline IEXAS & WEST RANCH & OTHER ZONES & OTHER ZONES & FRIO STANDPLAIN \\
\hline EXXAS & WEST RANCH & TONEY & TONEY & FFIO STANDPLAIN \\
\hline TEXAS & WEST RANCH & VANDERBILT SAND & VANDERBILT SAND & FFIO STANDPLAIN \\
\hline IEXAS & WEST RANCH & VENADO ZONE & VENADO ZONE & FAIO STANDPLAIN \\
\hline IEXAS & WEST RANCH & WAAD & WARD & FAIO STANDPLAIN \\
\hline TEXAS & WHITE POINT EAST & FA1O & FAIO & FAIO STANDPLAIN \\
\hline EXXAS & WHITE POINT, EAST & 4800 HET & 4800 HET & FRIO STANDPLAIN \\
\hline IEXAS & WHITE POINT, EAST & 6000 BAND & 5000 SAND & FAIO STANDPLAIN \\
\hline TEXAS & WITHERS, NORTH & & $7 x$ & FAIO STANDPLAIN \\
\hline IEXAS & WORTHAM & & WOODEINE & WOODBINE FAULT LINE \\
\hline TEXAS & YANTIS & & $T X$ & CRETACEOUS, SALT.RELATED \\
\hline UTAH & LISBON & MCCAACKEN & MCCAACKEN & PARADOX BASIN OEVONIAN \\
\hline WroMNa & CHAN & MUDDY & MUDDY SANDSTONE & LOWEA CAETACEOUS SIRANDPLAIN SS \\
\hline Wramna & COLLUMS & MUDDY & MUDDDY SANDSTONE & LOWER CAETACEOUS STRANDPLAIN SS \\
\hline WYAMNO & DEAD HORSE CAEEK & PARKMAN & MESAVERDE & UPPER CRETACEOUS PARKMAN SS.POWOER RIVER \\
\hline WYAMNG & DONKEY CAEEK & DAKOTA & DAKOTA (FALL RIVEA) & LOWEA CRETACEOUS STRANDPLAIN SS \\
\hline Wramina & FIDDLER CREEK & NEWCASTLE & NEWCASTLE SANDSTONES & LOWER CRETACEOUS STRANDPLAIN SS \\
\hline WroMna & GASDAAW & MUDDY & MUDDY SANDSTONE & LOWER CAETACEOUS STRANDPLAIN SS \\
\hline WYaAna & GILLETTE & MUDOY & MUDDY SANDSTONE & LOWER CRETACEOUS STRANDPLAIN SS \\
\hline Wromina & GAASB CAEEK & CUATIS & CHUOWATER (CROW MOUNTAIN SSA & 1) TRIASSIC NEARBHORE SS.BIQ HORN BASIN \\
\hline WroMNa & QRASS CREEK & DARWIN & AMBDEN (OARWIN SS) & TAANSGRESSIVE AMSDEN DEPOSITS.BIGHORN BASIN \\
\hline Wromna & QAIEVE & MUDDY & MUDDY SANDSTONE & LOWERCRETACEOUSMUDDYSS \\
\hline Wromina & HAMILTON DOME & CURTIS & CHUGWATER CCROW MOUNTAIN SSA & 1) TRIASSIC NEARSHORE SS.BIG HORN BASIN \\
\hline WraMne & HILIGHT & MUDDDY, MINNELUSA & MUDDY SANDSTONE & LOWER CRETACEOUS STRANDPLAIN SS \\
\hline Wramna & KITTY & MUDDY & MUDDY SANDSTONE & LOWER CRETACEOUS STAANDPLAIN SS \\
\hline Wronns & KUMMERFELD & COMBINED & DAKOTA (FALL RIVER) & LOWER CAETACEOUS DAKOTA STRANDPLAIN SS \\
\hline WYOMNG & LOST SOLDIEA & FLATHEAD & FLATHEAD SANDSTONE & MIDDLE CAMBAIAN FLATHEAD SS.SWWY \\
\hline WYOMNO & MILL & MUDDY & MUDDY SANDSTONE & LOWER CAETACEOUS STRANDPLAIN SS \\
\hline WYOMNQ & MILLEA CREEK & DAKOTA & DAKOTA (FALL RIVER) & LOWEA CRETACEOUS DAKOTA STRANDPLAIN SS \\
\hline wromina & PATRICK DRAW (MONNEL UNIT) & ALMOND & ALMOND & UPPEA CRETACEOUS ALMOND BARRIER BASS SWWY \\
\hline WroNANa & PATAICK ORAW (PECH UNIT) & ALMOND & ALMOND & UPPER CRETACEOUS ALMOND BARAIER BAFS SWWY \\
\hline Wronns & POISON SPIDER, WEST & MESAVEAOE & MESAVEADE & UPPER CAETACEOUS MESAVERDE SS.WND RIVER \\
\hline WOMNA & RECLUSE & MUDDY & MUDDY SANDSTONE & LOWER CRETACEOUS STRANDPLAIN SS \\
\hline uromina & ROCK AIVER & CAETACEOUS & MUDDY, DAKOTA, LAKOTA & LOWER CRETACECUS SS COMMMINGLED-SWWW \\
\hline WroMne & ROZET & MUDDY & MUDDY SANDSTONE & LOWER CAETACEOUS STRANDPLAIN SS \\
\hline WYOMNO & SANDBAR, EAST & MUDDY & MUDDY SANDSTONE & LOWER CAETACEOUS STRANDPLAIN SS \\
\hline WOMMNG & SOUTH QLENROCK & UPPEA MUDDY B CONOCO ONLY & MUDDY SANDSTONE & LOWER CAETACEOUS STRANDPLAIN SS \\
\hline WroMna & SPAINGEN RANCH & MUDDY & MUDDY BANDSTONE & LOWER CRETACEOUS STRANDPLAIN SS \\
\hline Wronina & UTE & MUDDY & MUDDY SANDSTONE & LOWER CRETACEOUS STRANDPLAINSS \\
\hline WrOANG & WEATZ & AMSDEN & AMSDEN (DARWIN SANDSTONE) & UPPERMIBSISSIPPIAN DARWIN STRANDPLAIN-SWWV \\
\hline WYOMNG & WHITETALL & MUDDY & MUDDOY SANDSTONE & TLOWER CAETACEOUS STRANDPLAIN SS \\
\hline
\end{tabular}

